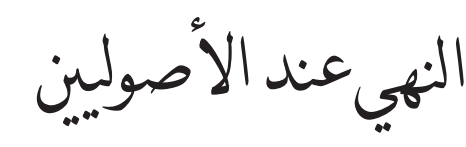

》داسة أصولية تطبيقية

د أسعد عبد الفني السيد الكفراوي أستاذ أصول الفقه المساعد بكي الميلية الدراسات الإسلامية والعربية- بنين- بالقاهرة - جامعة المساعد الأزهر العراس

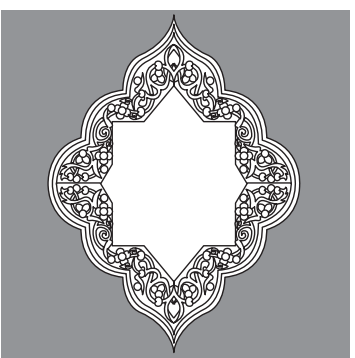

(تتمة البحث المنشور

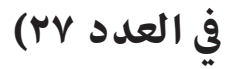

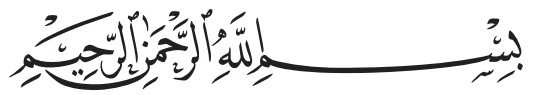

المسألة السابعة:

ما يلدل عليه النهي المطلق من المرة أو التكرار، والثور أو التراخي(1)

اختلـفـ الأصوليـون في صيغة النهـي المجردة عن قيـد بمرة أو زمان معيـن، هل تفيد

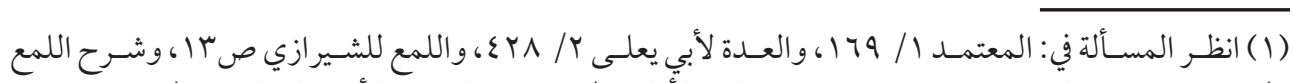

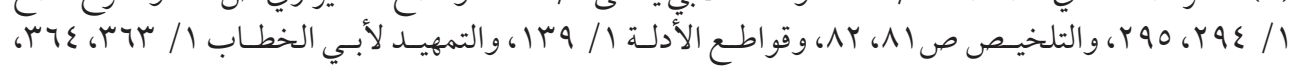

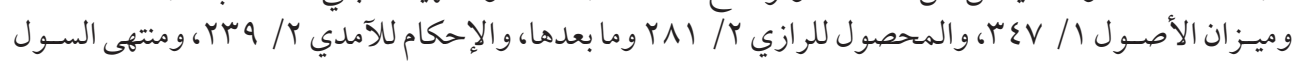

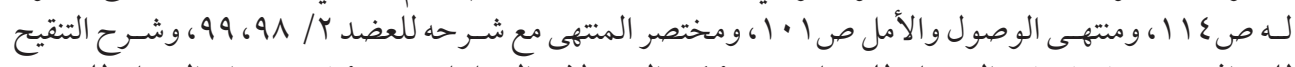

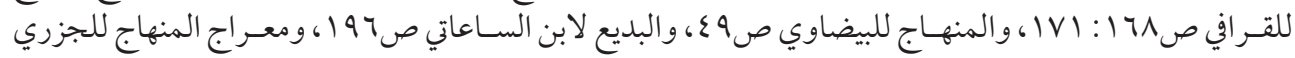

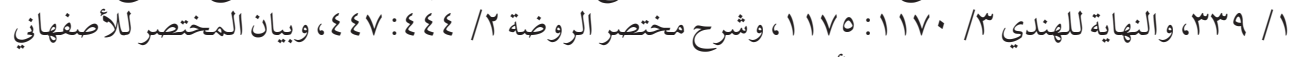

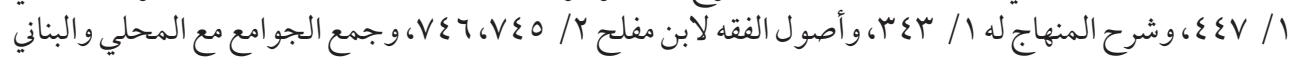

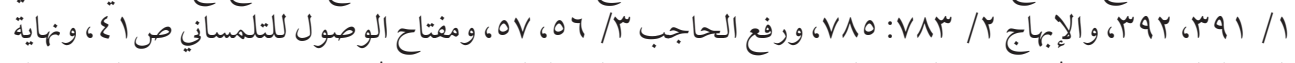

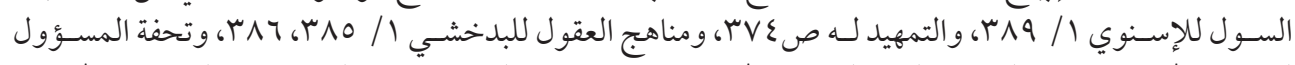

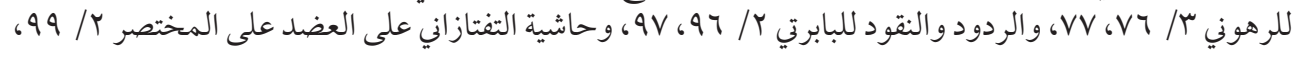

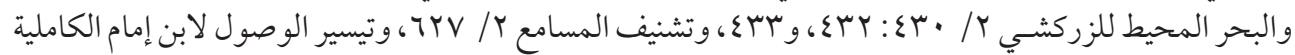

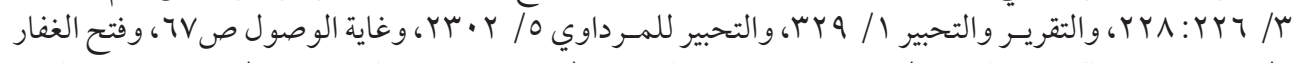

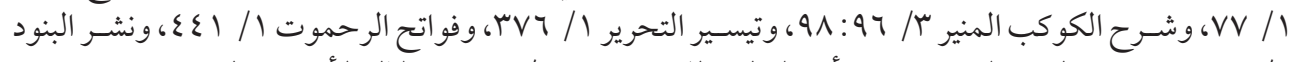

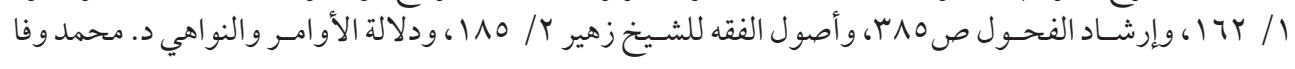




$$
\text { التول الأول: ألتوار المرة، أو الفور أو التراخي؟ على قولين: }
$$

أن النهي يقتضي المبادرة إلى ترك المنهي عنه على الفور، ويقتضي تكرار الانتهاء عنه

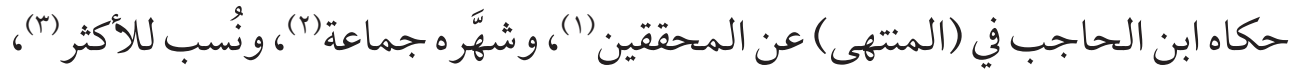

وللجماعة غير الباقلاني، والإمام الرازي (ع).

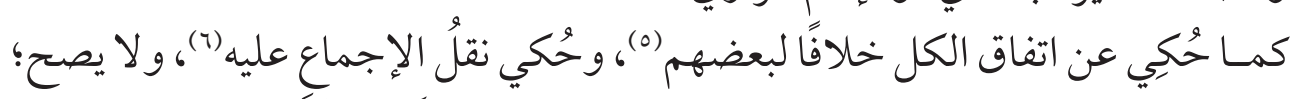

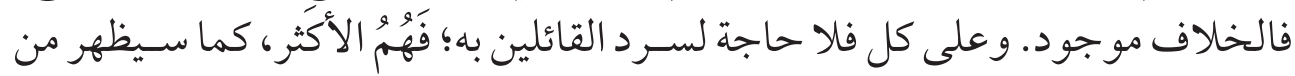
حصر المخالف في القول الثاني (v).

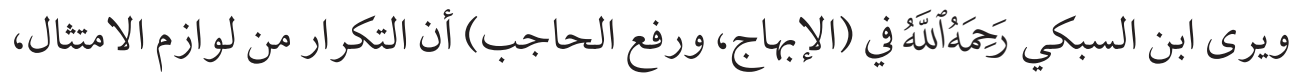

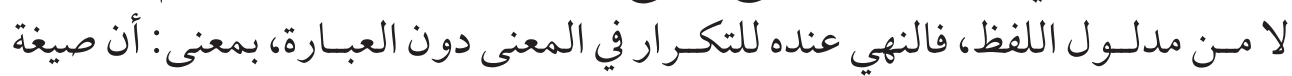

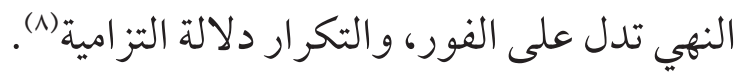
القول الثاني: أن النهي لا يقتضي تكرارًا ولا فورًا.

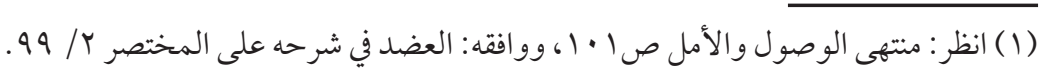

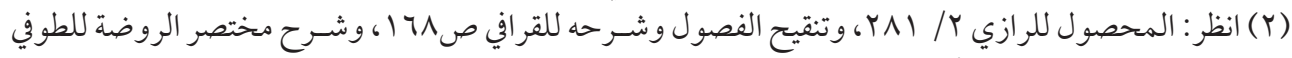

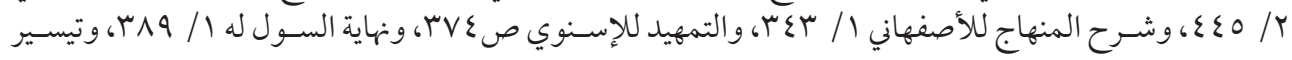

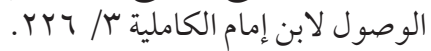

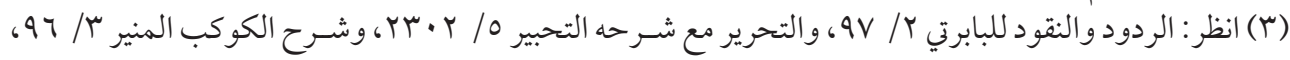

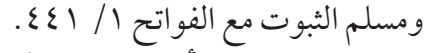

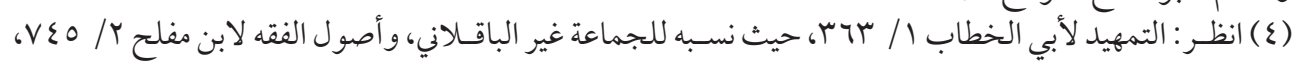

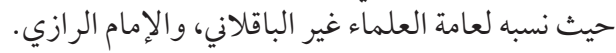

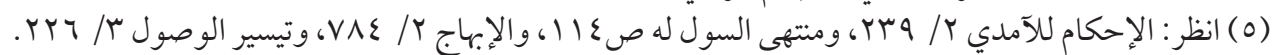

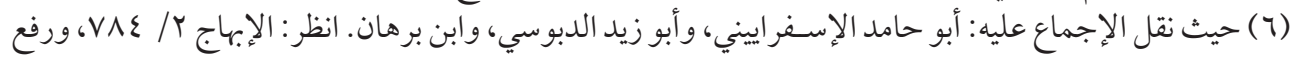

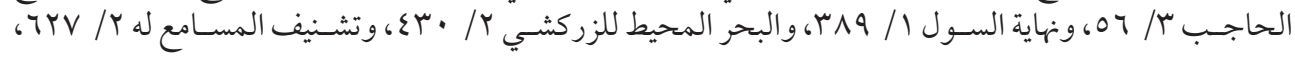

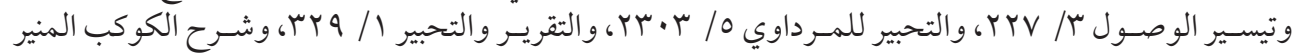

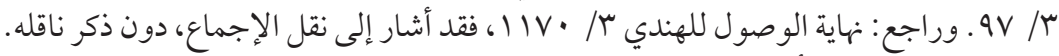

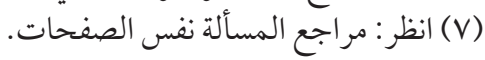

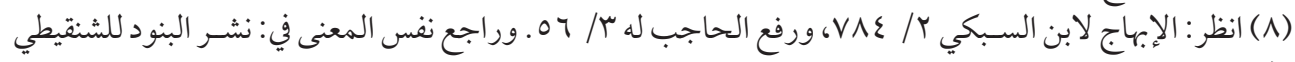


وهـو مختــار الباقـالاني (1) علـى مـا في (التقريب و الإرشـاد) لـه، و(التلخيـص) لإمام

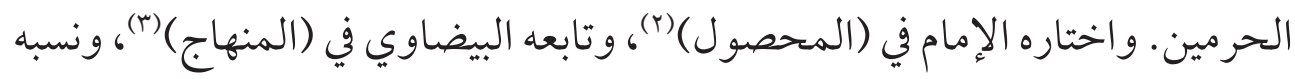
جماعة للبعض دون تصريح بهم (ع) .

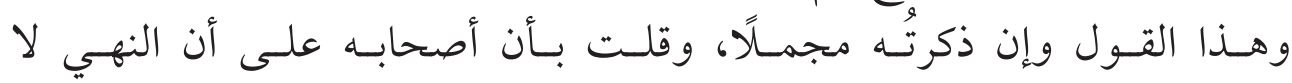

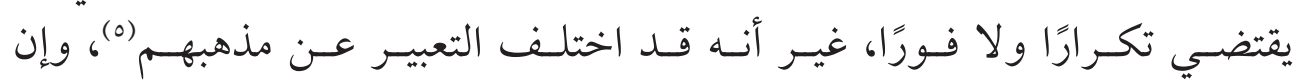

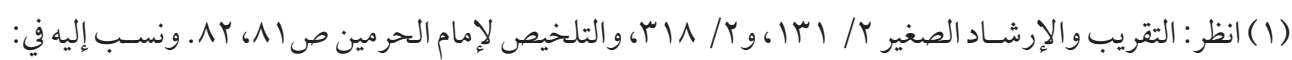

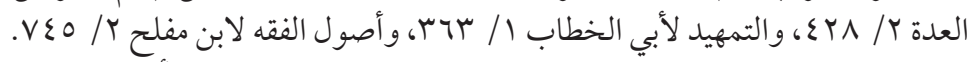

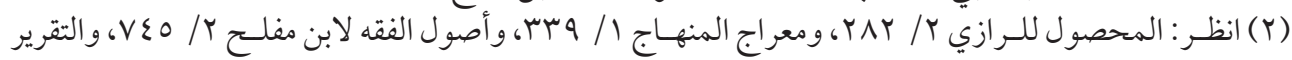

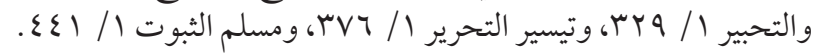

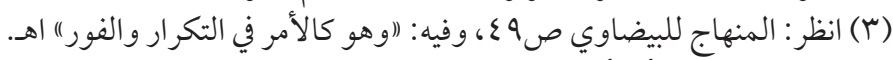

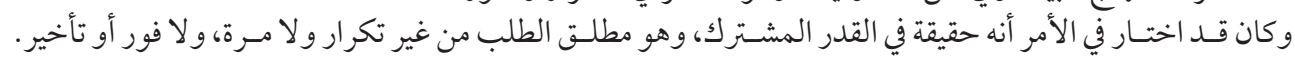

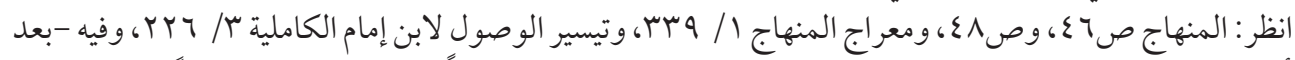

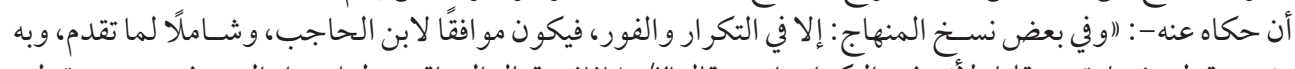

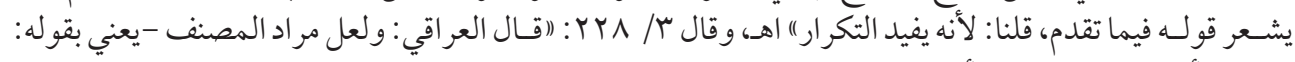

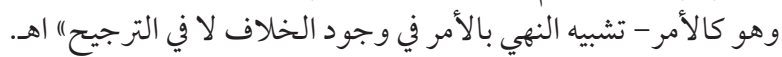

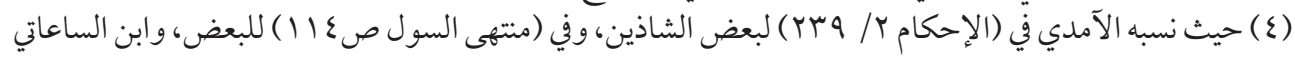

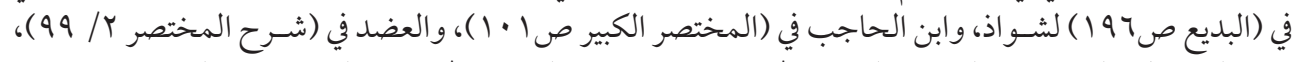

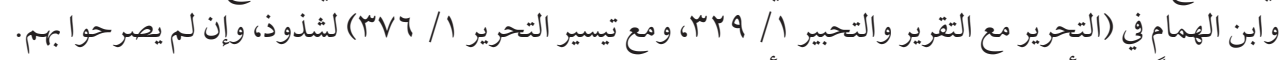

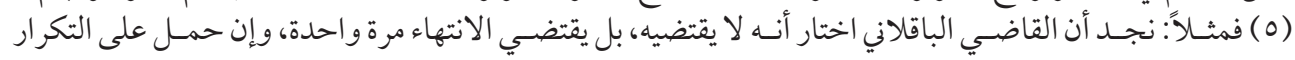

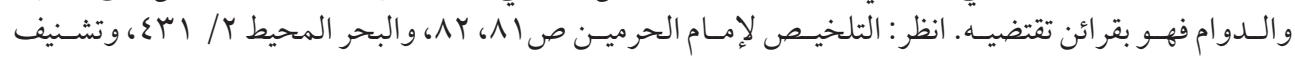

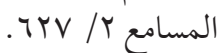

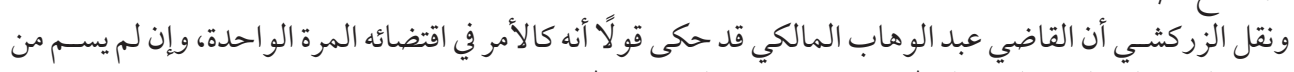

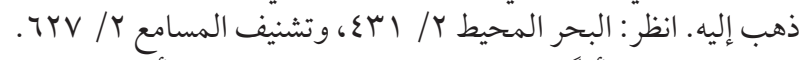

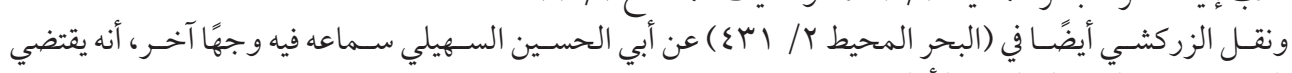

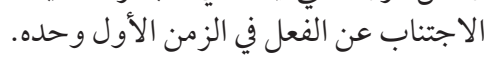

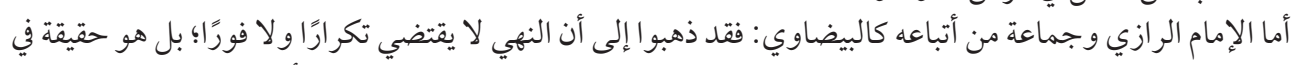

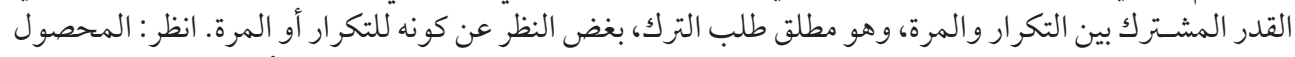

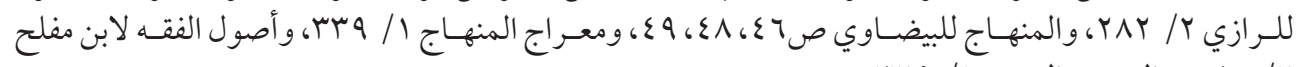

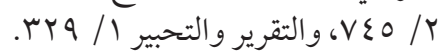

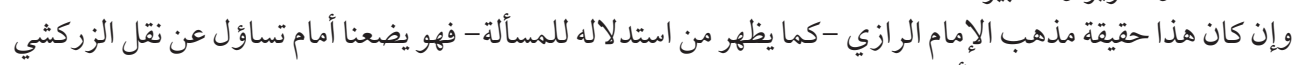

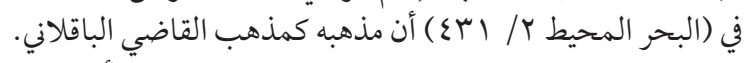

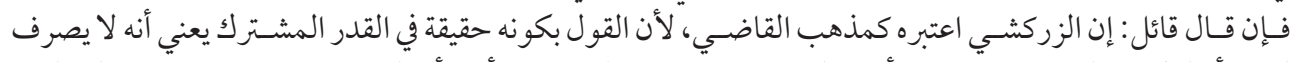

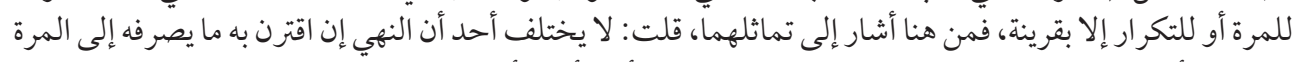

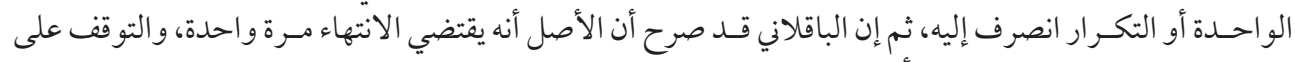

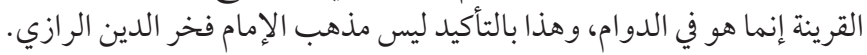

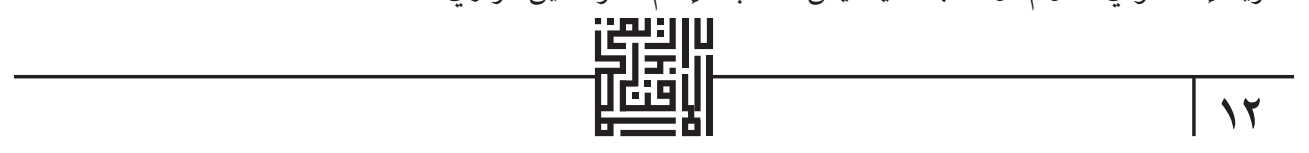




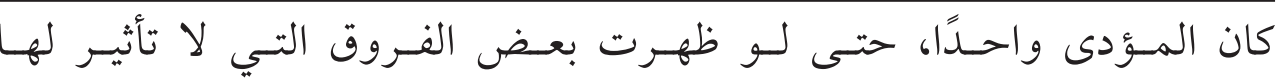

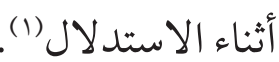
هذا: وللزر كشي في (البحر المحيط) تخريج قول على ما سبق في الأمر، وهو : التفصيل

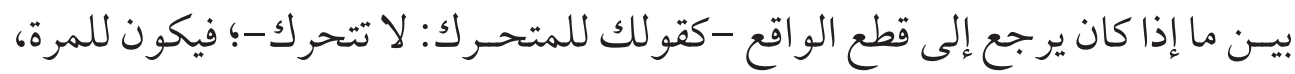

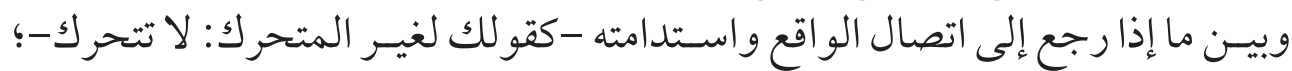

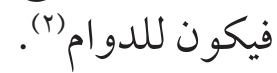

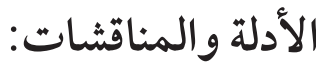

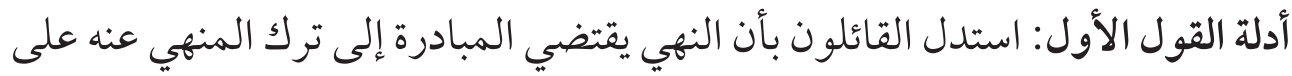

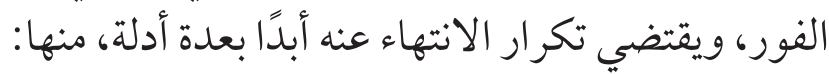

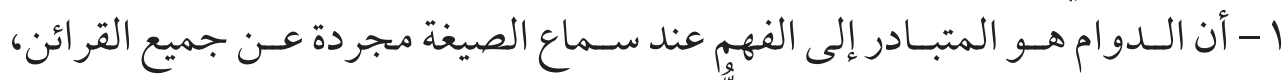

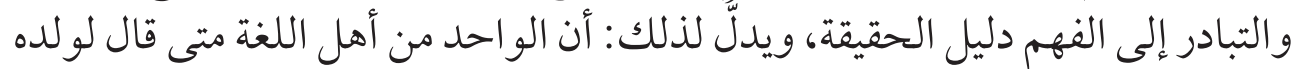

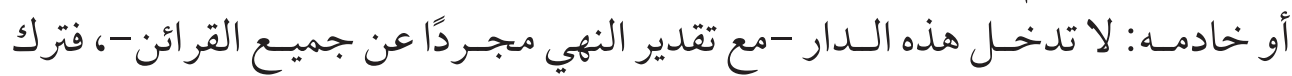

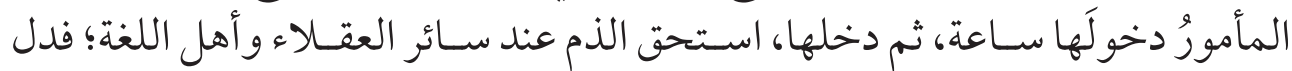

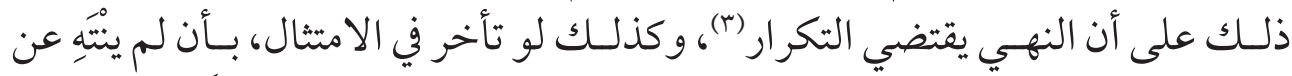

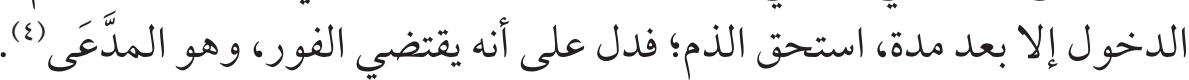

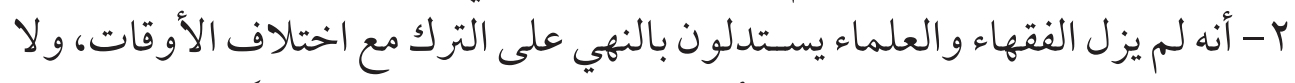

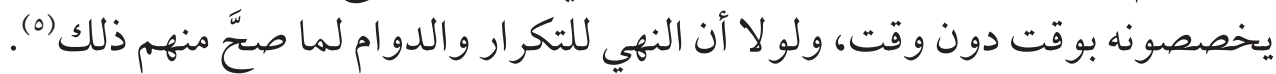

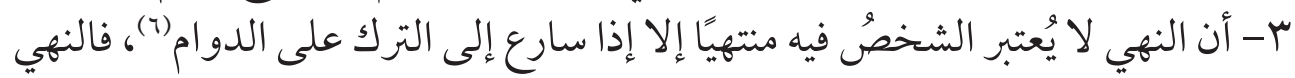

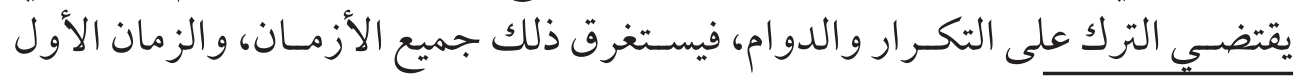

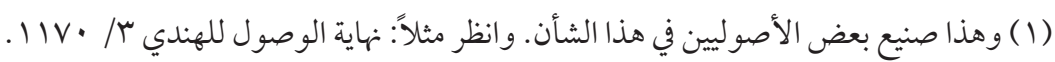

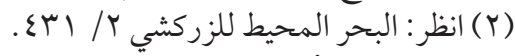

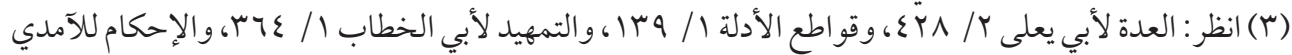

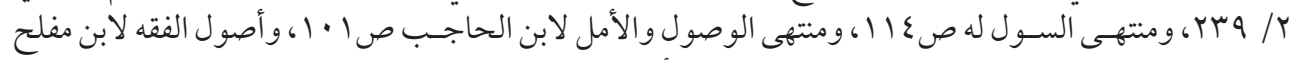

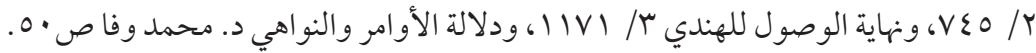

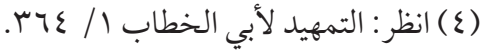

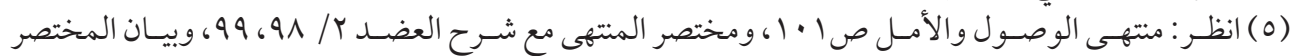

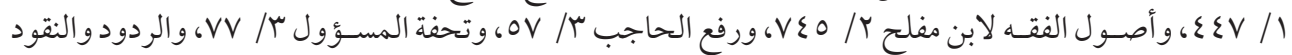

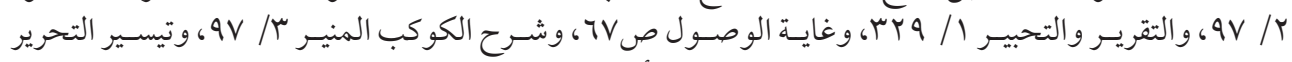

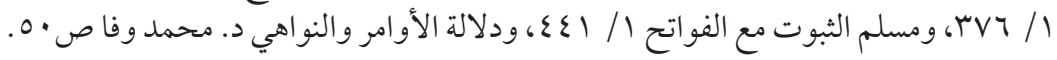


الـذي يلي الخطاب من جملة الأزمان الداخلة في النهي، فوجب الكف فئف في الزمن الأول ليصير المكلف عاملًا بمقتضى النهي (1).

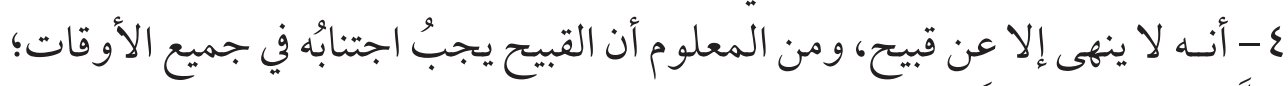

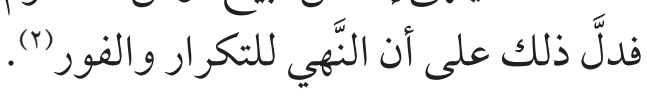

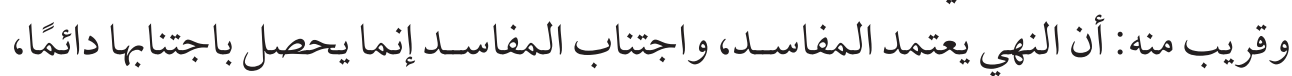

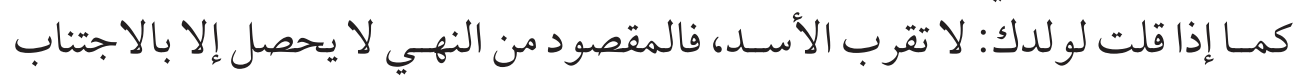

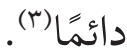
ه - أنه يصح اسـتشناء أي زمان شـاءه الناهي، بأن يقول مثلًا: (الا تضرب فلانًا إلا وقتَ

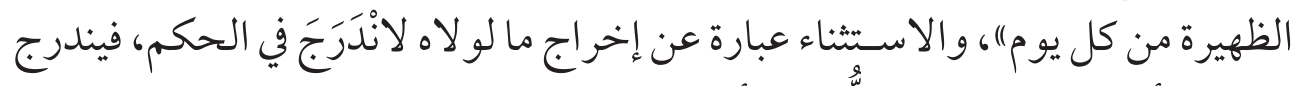

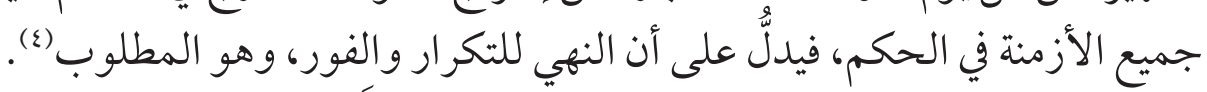

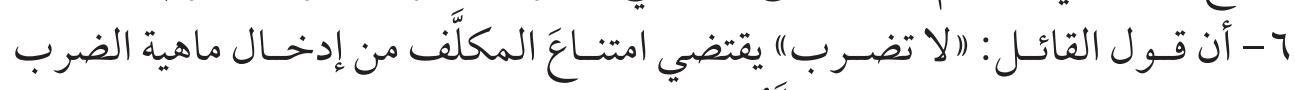

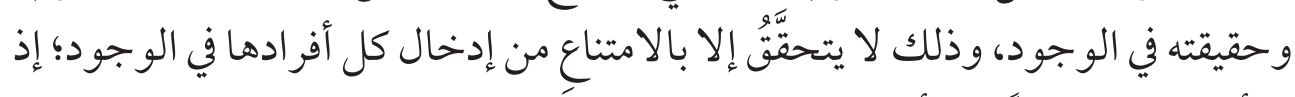

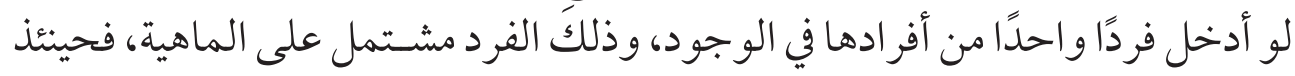

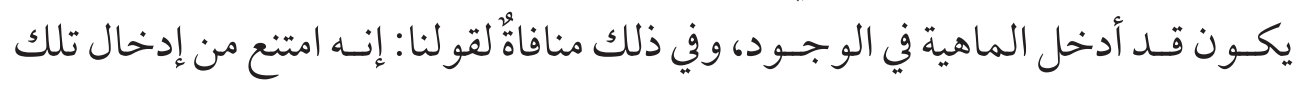

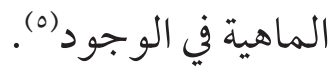

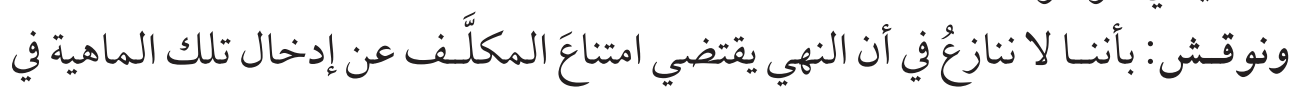

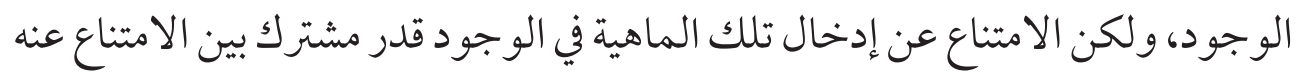

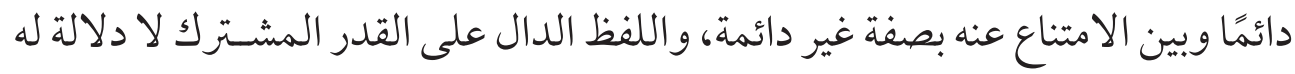
على ما به يمتاز كل واحد من القسمين عن الثاني (ج). و أجيب: بأن النهي يقتضي امتناع المكلف عن إدخال تلك الماهية فئ في الو جود في الدوام

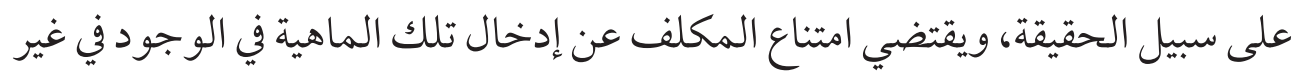

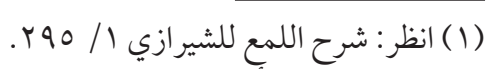

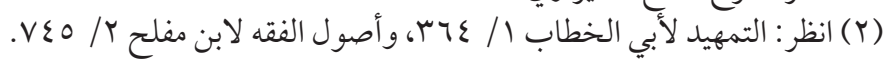

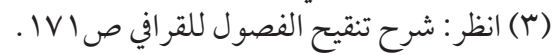

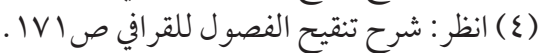

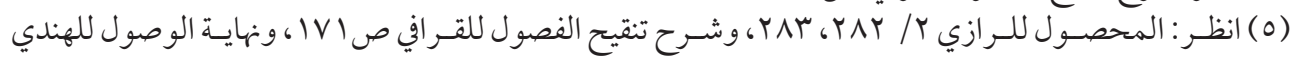




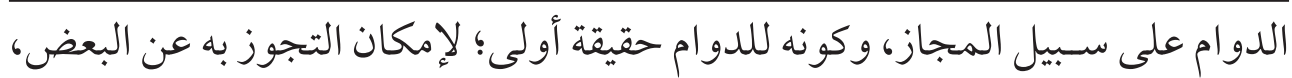

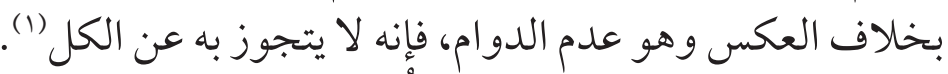

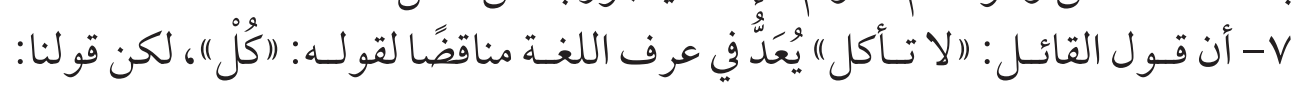

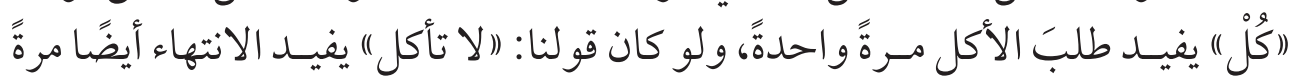

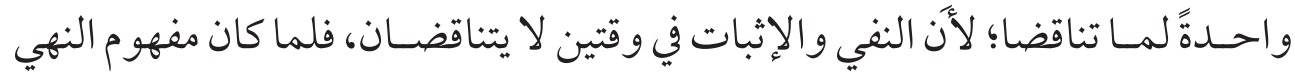

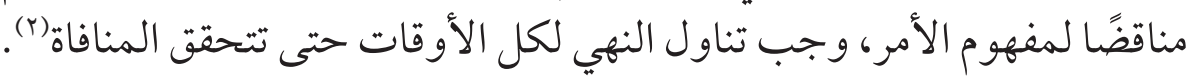

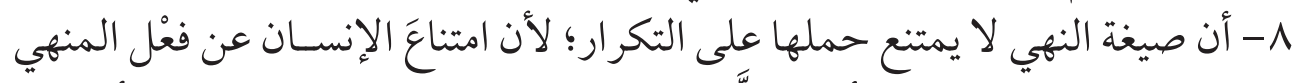

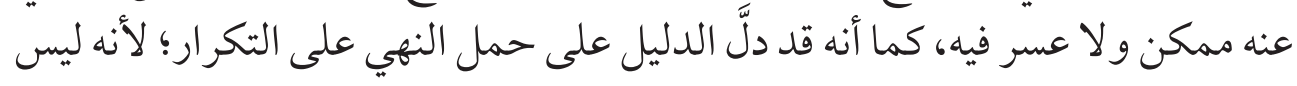
في الصيغة دلالة على وقت دون وقت، فوجب الحمل فمل على كلى الكل دفعًا للإجمال.

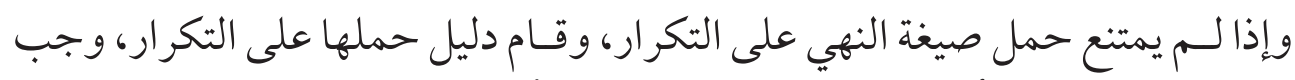

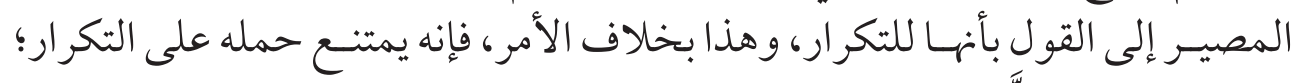

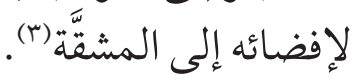

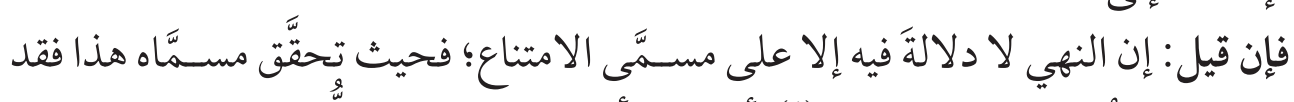

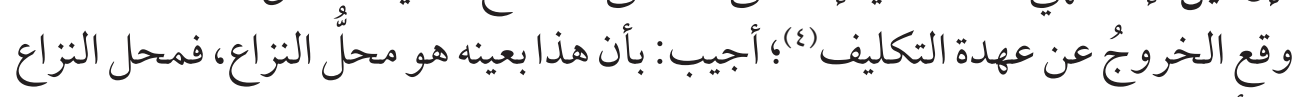
إذا أطلقـت صيغة النهي المجردة، فهل يكفي في تحققها وصدق دلا لالتها على مسـماها

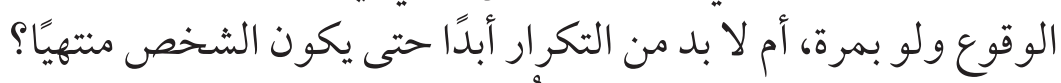

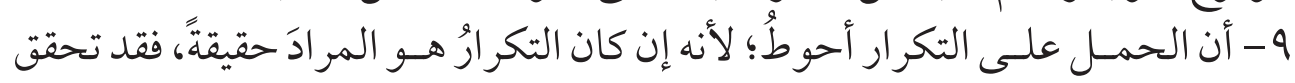

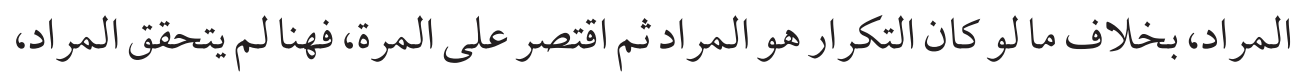

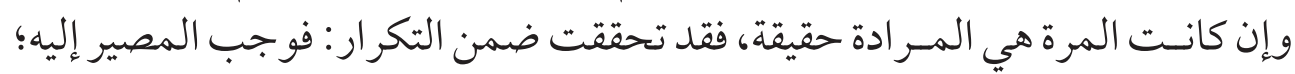

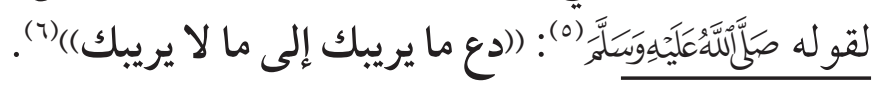

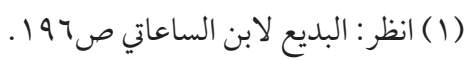

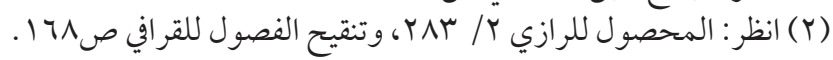

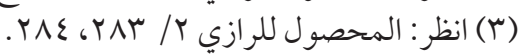

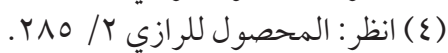

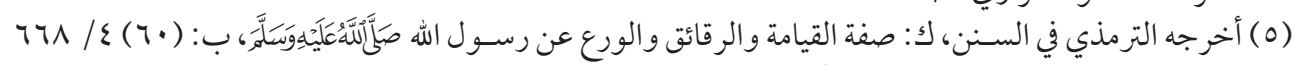

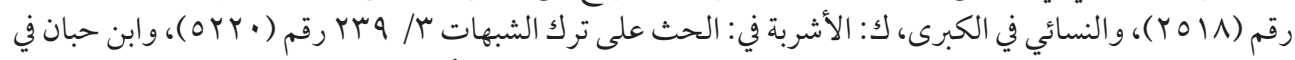

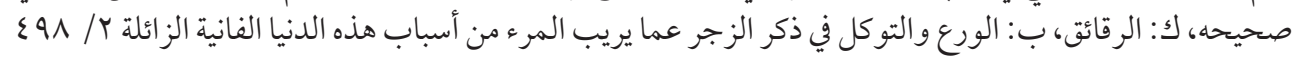

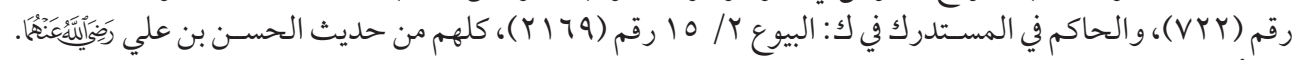

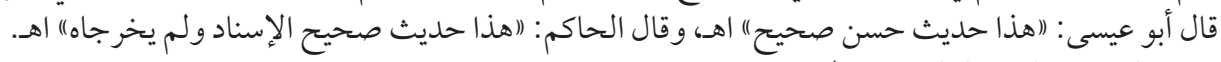

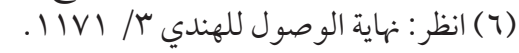


أدلة القول الثاني: استدل القائلون بأن النهي لا يقتضي تكرارًا ولا فورًا، بعدة أدلة، منها:

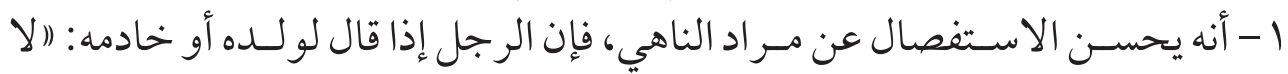

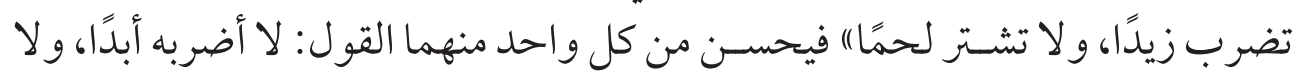

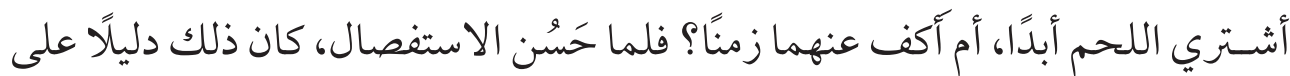

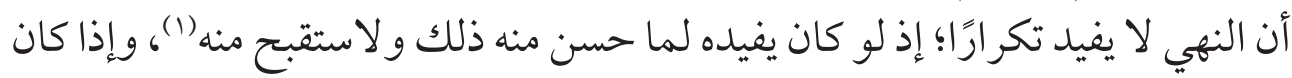
لا يفيد التكرار فهو لا يفيد الفور. Y - القيـاس على الأمر، فالأمـــ لا يقتضي الفور و المداومة، فكذلك النهي، بل فيل غاية ما

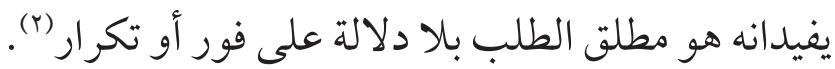

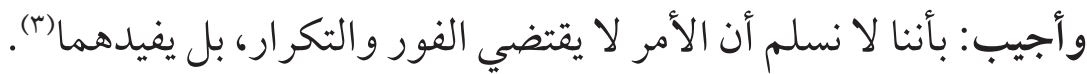

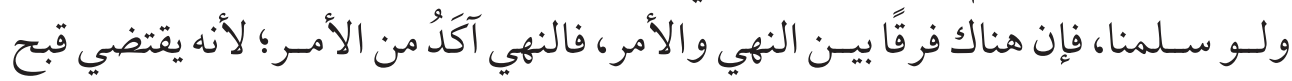

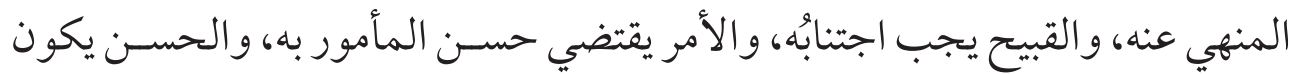

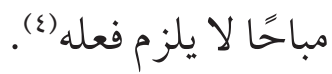

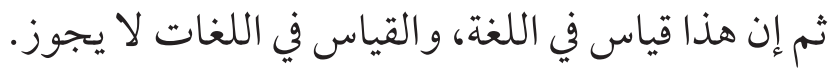

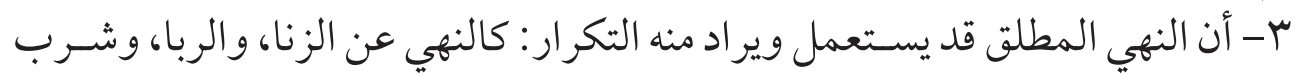

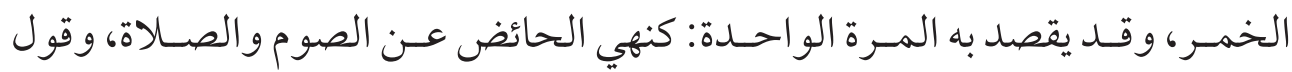

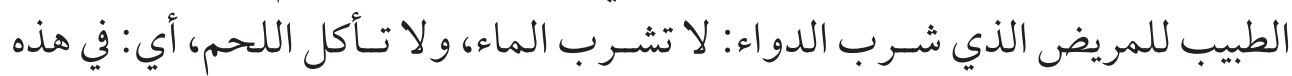

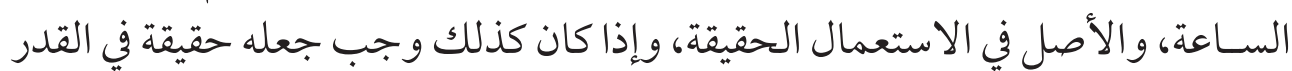

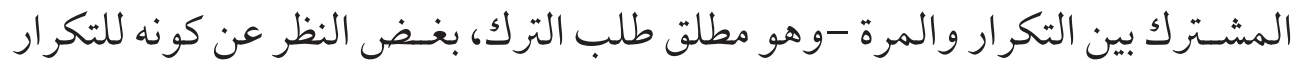

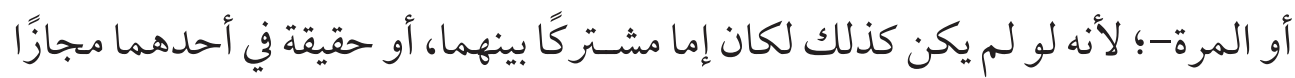

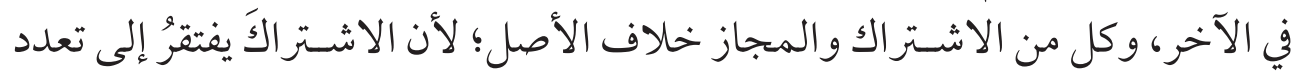

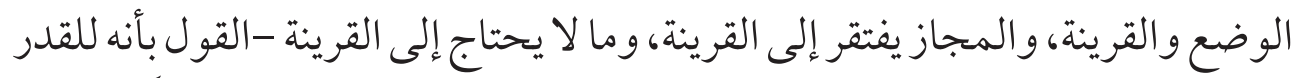

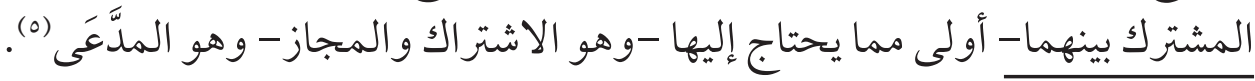

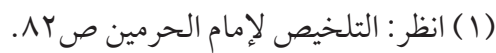

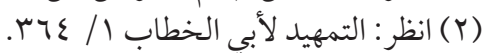

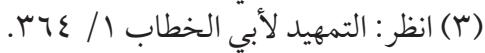

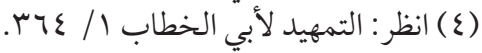

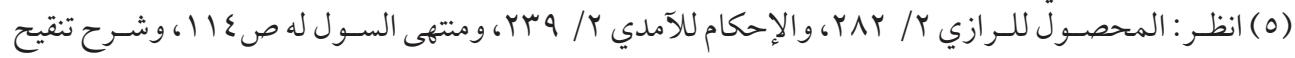

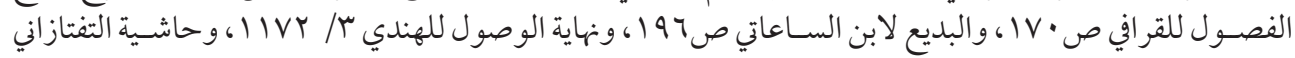




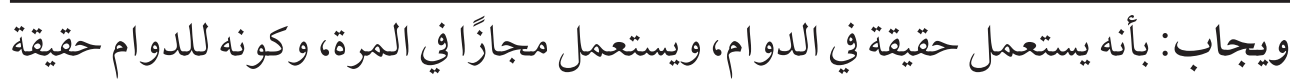

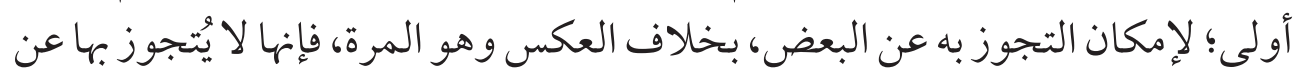

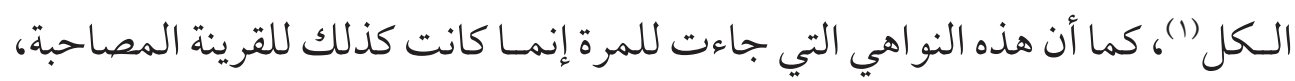

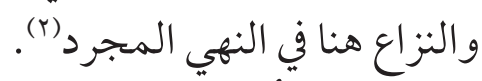

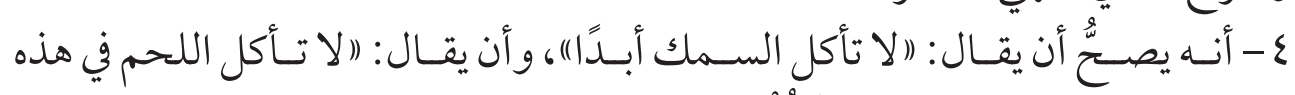

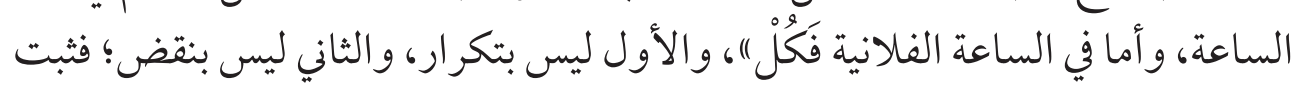

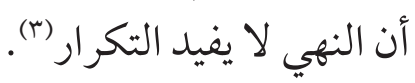

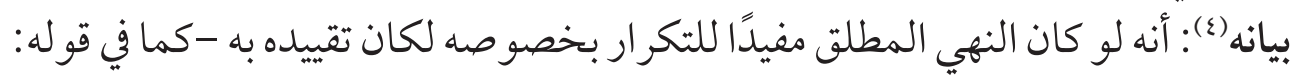

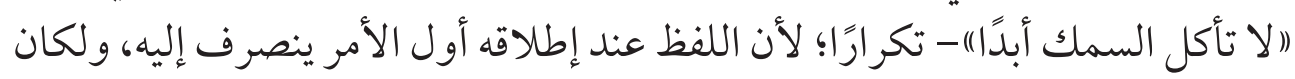

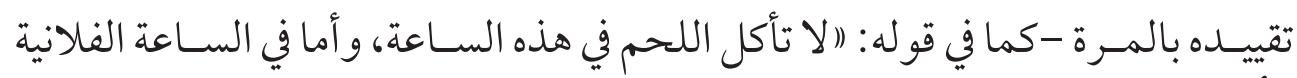

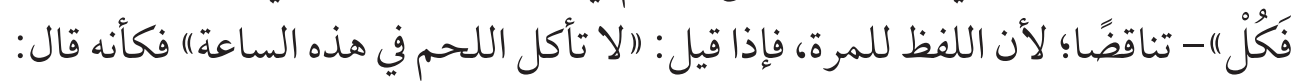

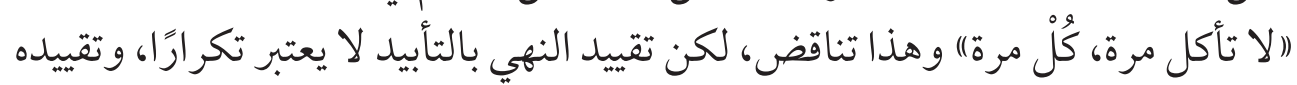
بالمرة لا يعتبر تناقضًا.

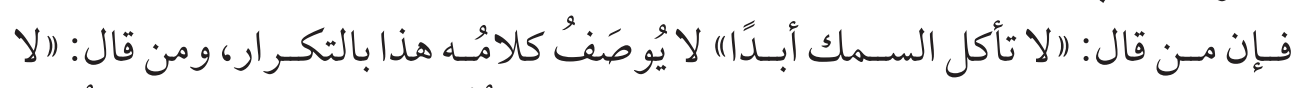

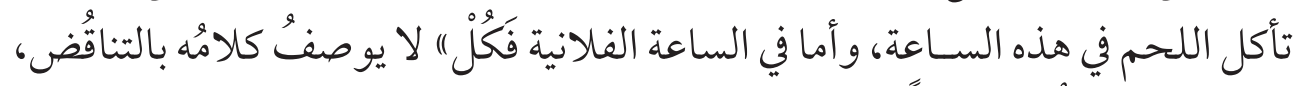

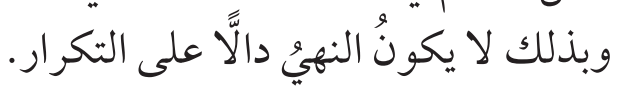

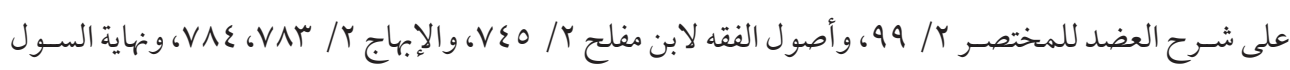

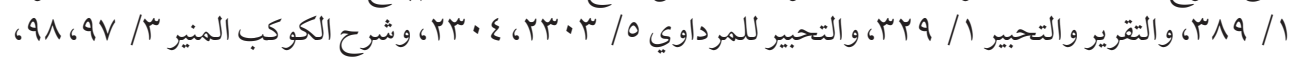

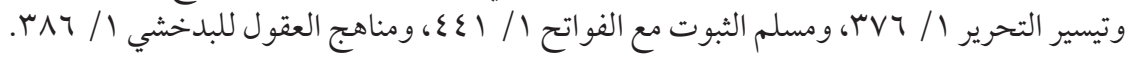

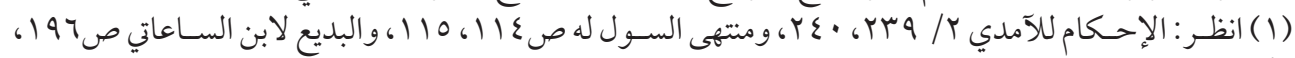

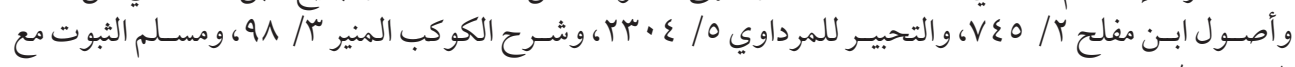

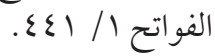

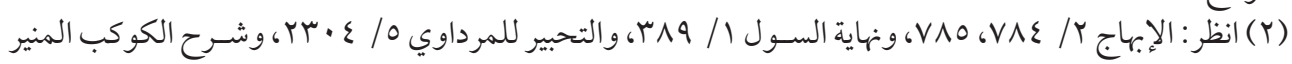

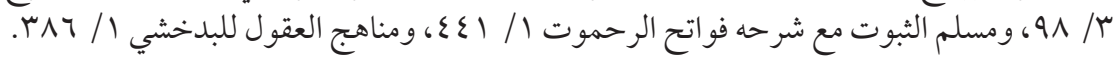

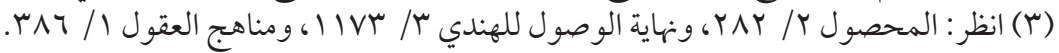

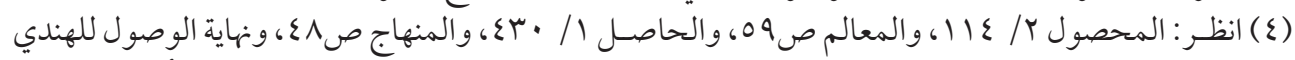

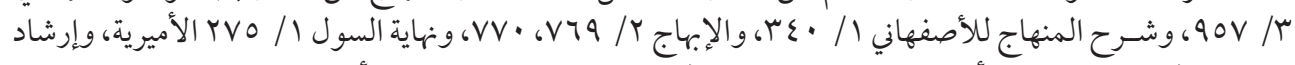

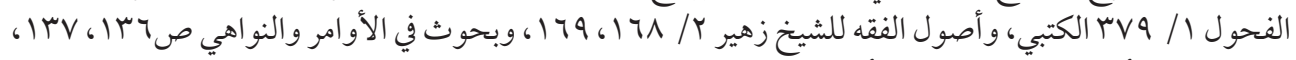

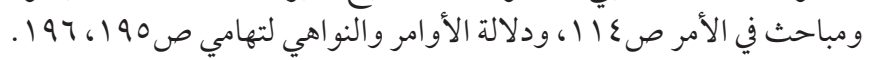




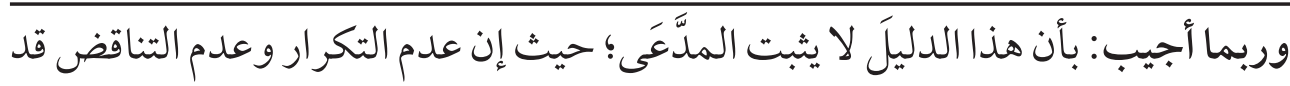

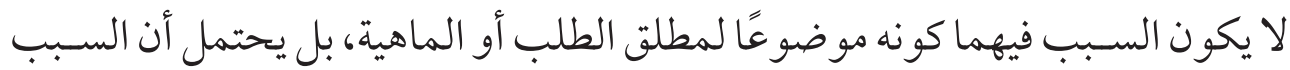

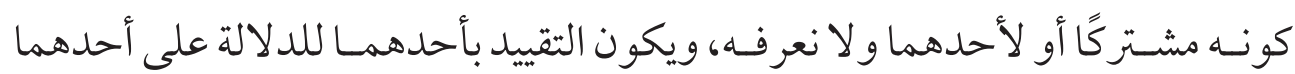
بخصو صنه (1). ه - أنه لو كان للدوام لما انففَكَّ عنه، وقد انْفَكَّك عنه في صور كثيرة، كما في نهي الحائض

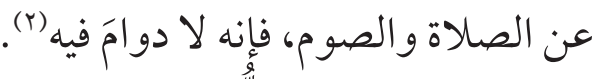

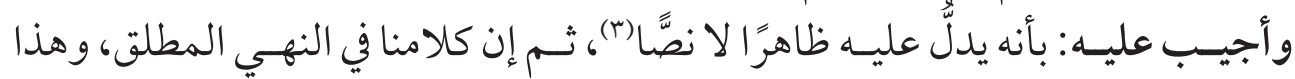

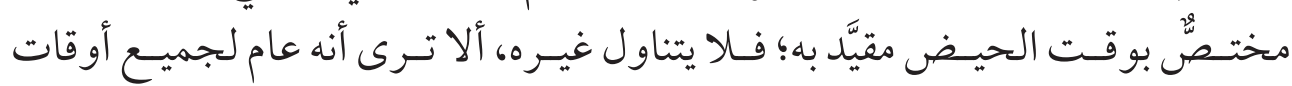

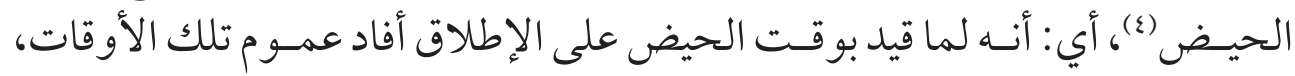

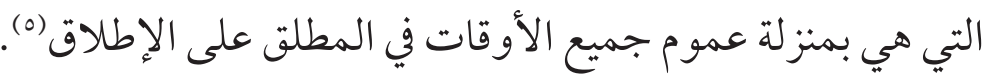

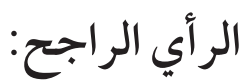
الراجح -و الله تعالى أعلم- هو قولُ الجمهور من أن صيغة النهي المجردة تفيد التكرار و الفور؛ لقوة أدلتهم، وضعف أدلة المخالفين كما اتضح.

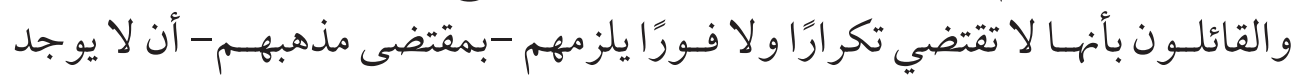

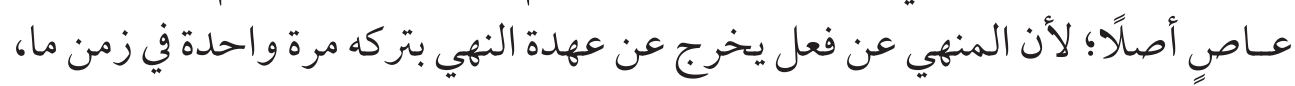

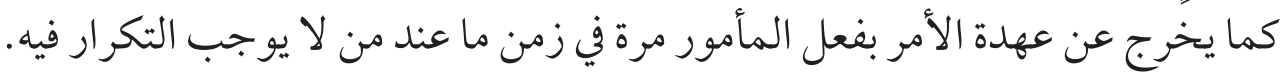

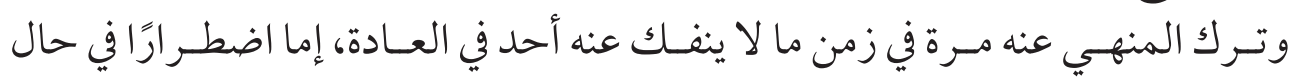

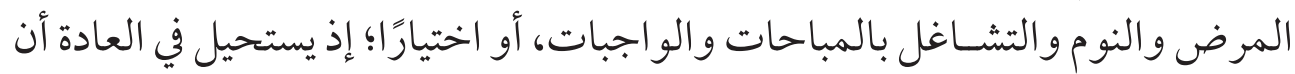

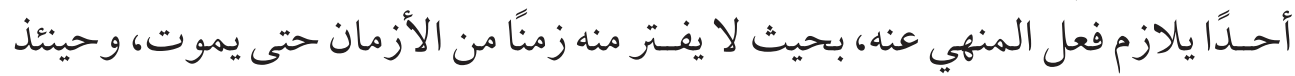

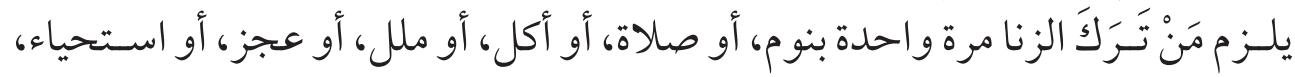

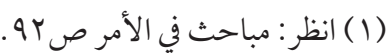

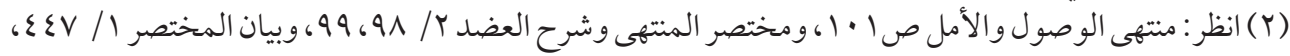

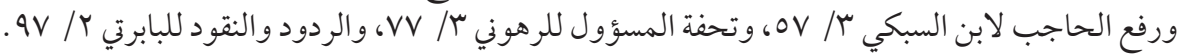

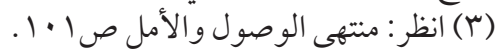

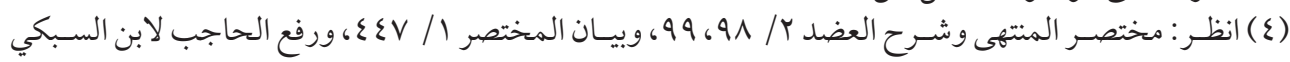

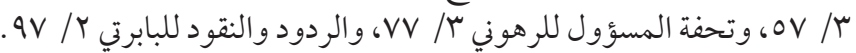

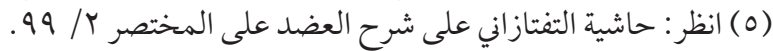


أو اختيـارًا محضًا، وفعله في بقية أزمانه أن يكـــون مطيعًا خارجًا عن عهدة النهي، وهذا

$$
\text { تاطل بالإجماع (1). }
$$

ا - معظم الكلام في الأدلة السـابقة يَنْصَبُُّ على التدليـل للتكر ار؛ لأنه إذا ثبت التكرار

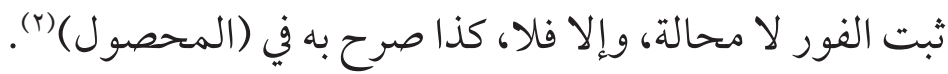
قال القرافي (r) في (شرح تنقيح الفصول): (وإذا فرعنا على التكرار، اقتضى الفور قطعًا؛

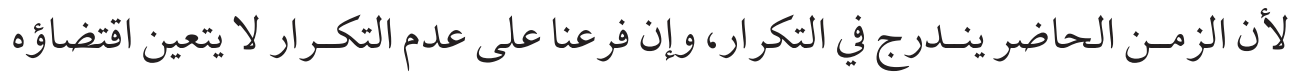

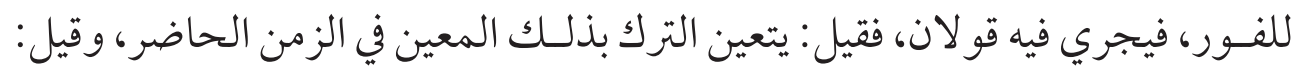

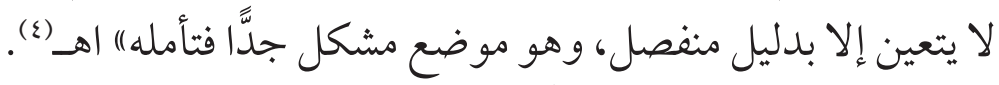

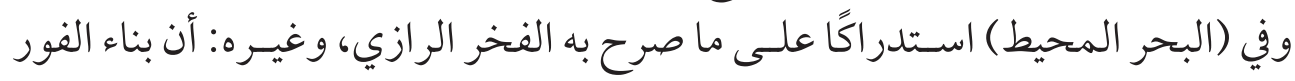

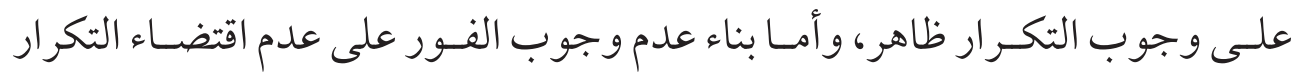
فمشكل؛ لجواز أن لا يقتضي التكرار ويقتضي الفور (0)

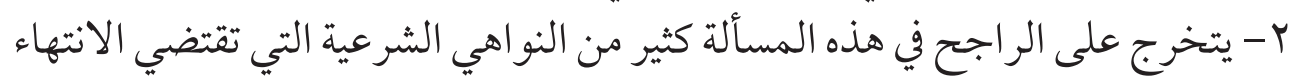
عن المنهي عنه فورًا، وتقتضي تكرإِ الانتهاء أبدًا.

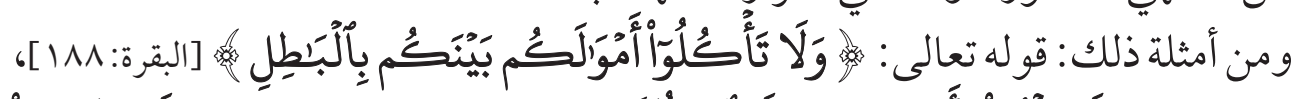

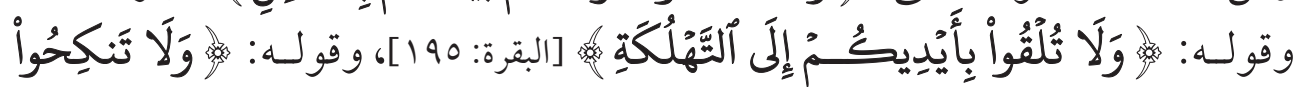

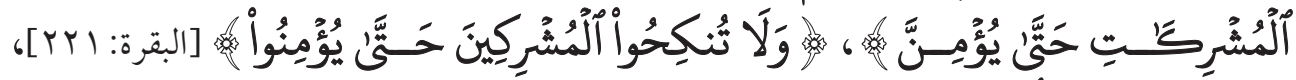

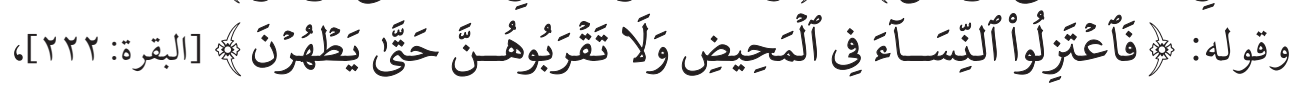

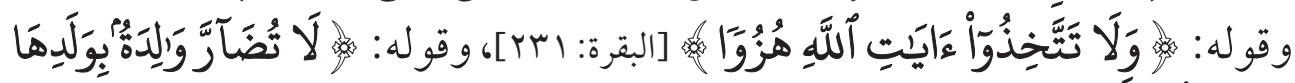

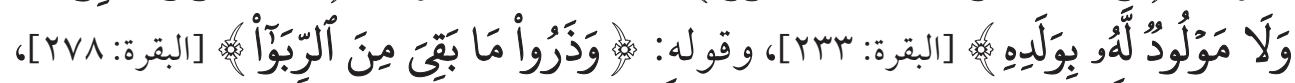

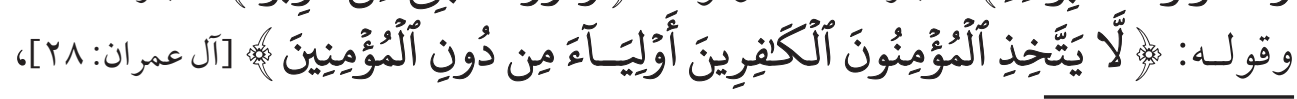

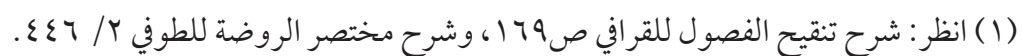

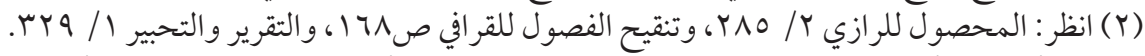

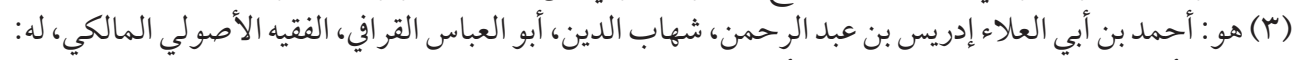

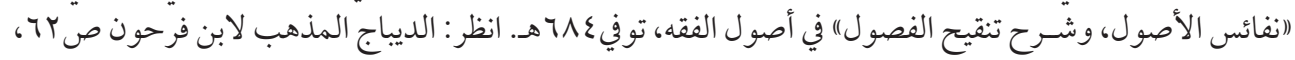

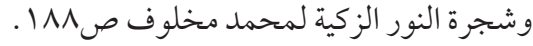

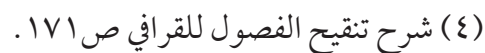

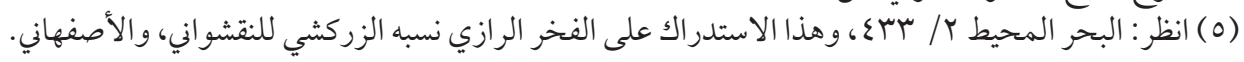




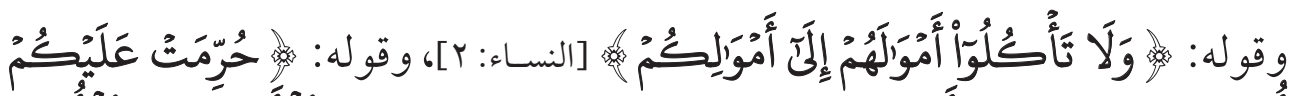

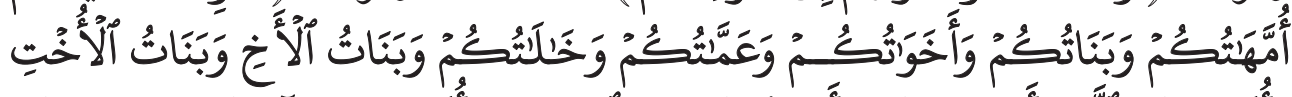

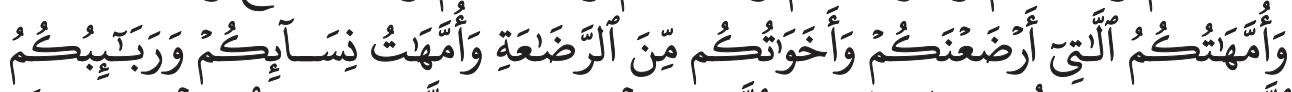

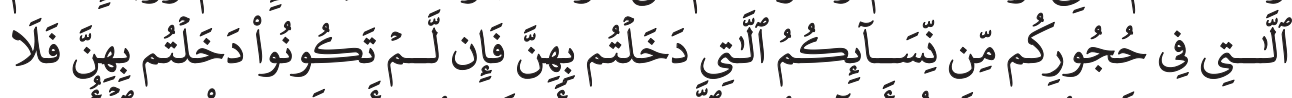

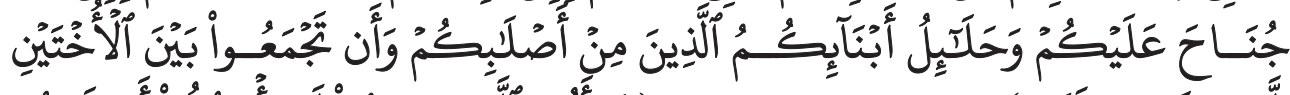

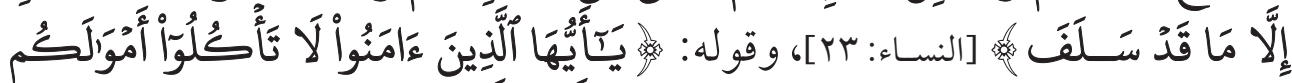

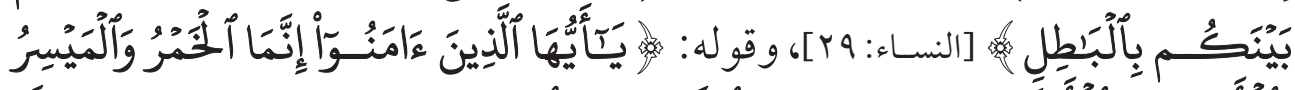

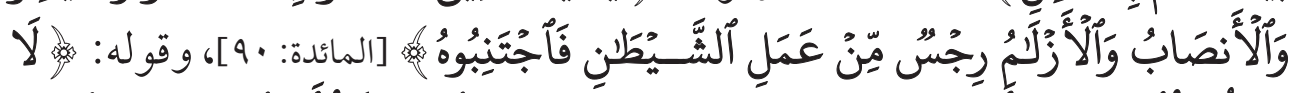

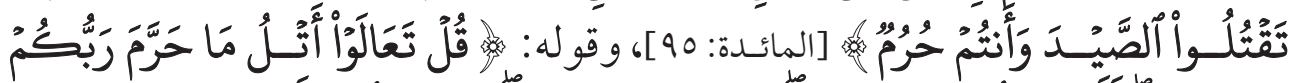

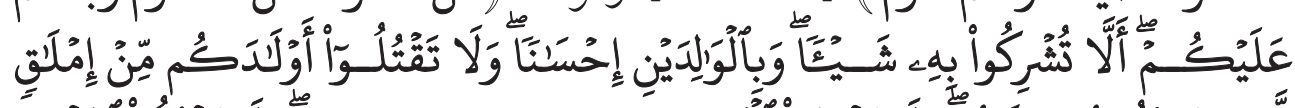

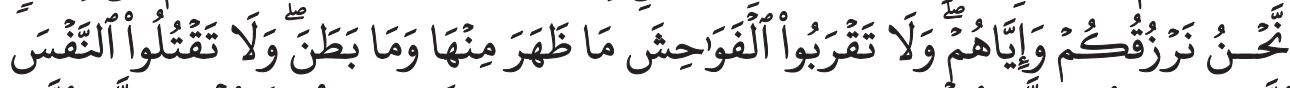

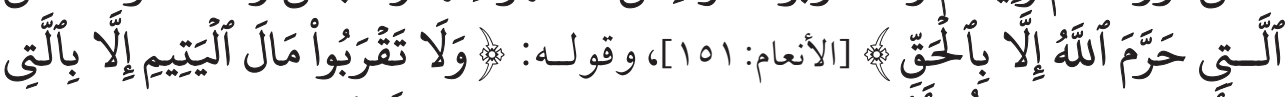

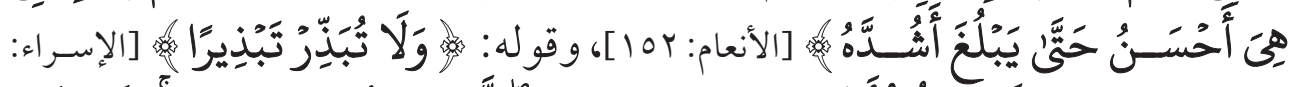

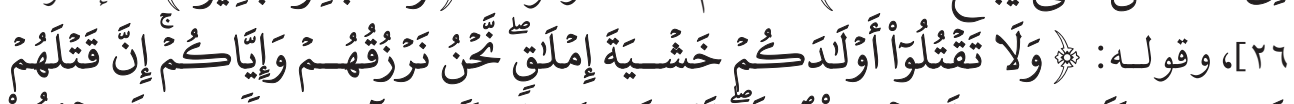

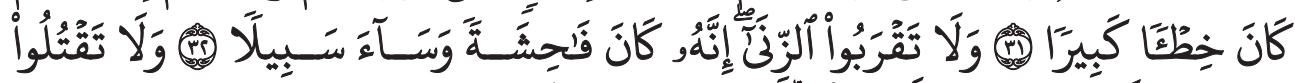

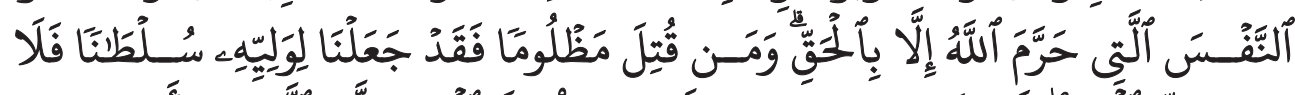

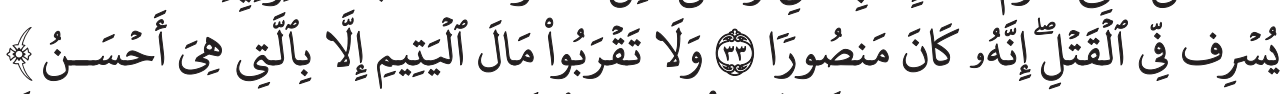

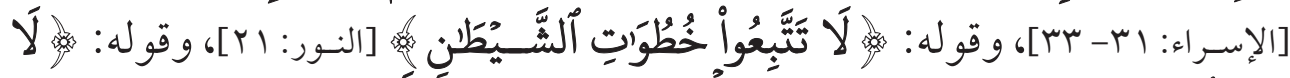

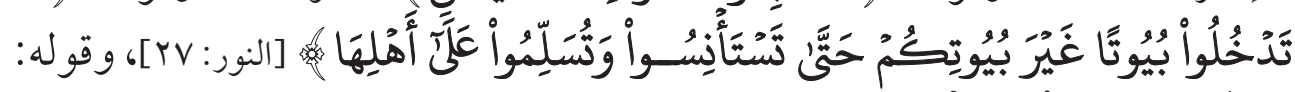

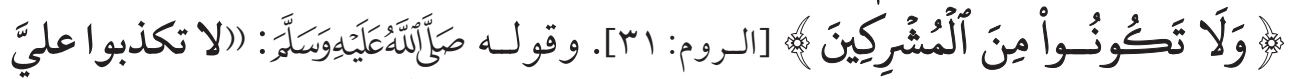

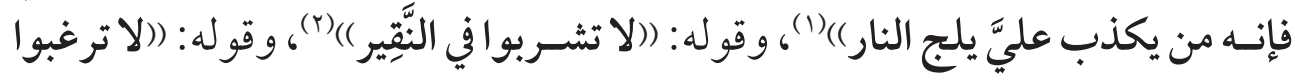

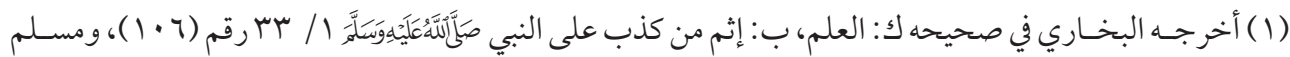

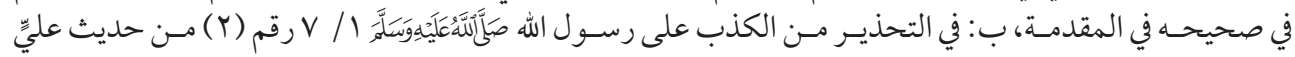

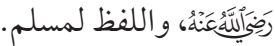

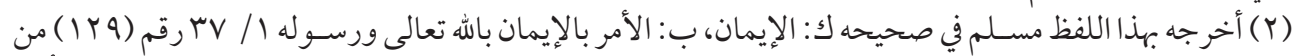

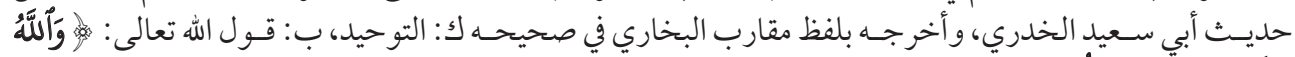

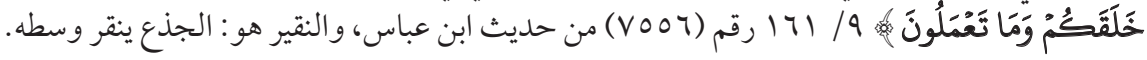


عـن آبائكم فمن رغب عـن أبيه فهو كفر )(1)، وقوله: (لا ترجعـوا بعدي كفارًا يضرب

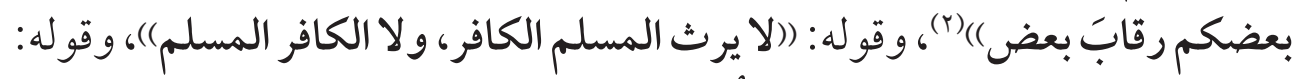

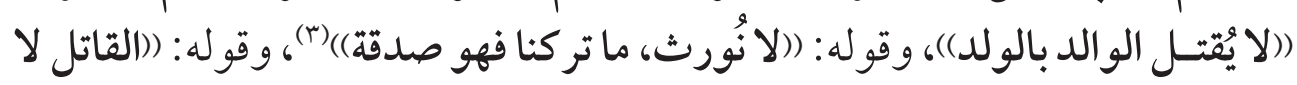

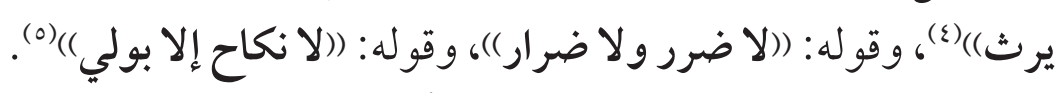

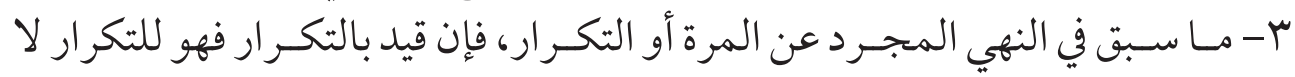

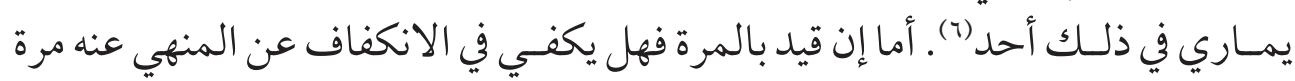

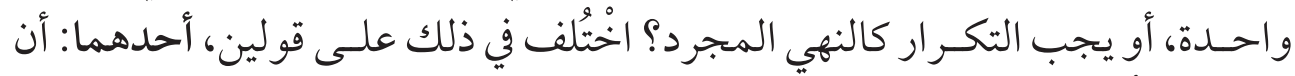

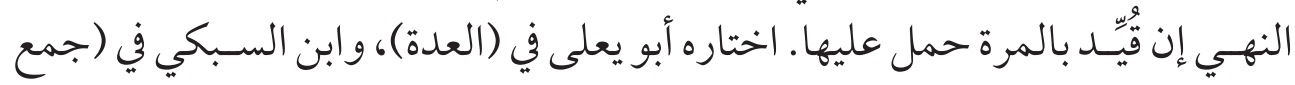

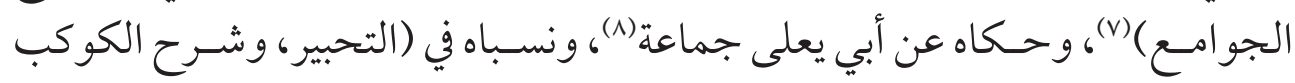

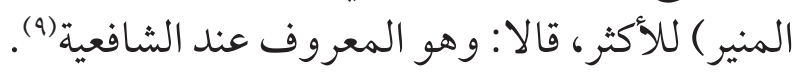

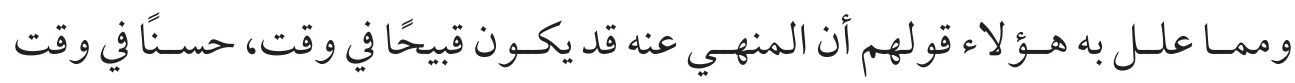

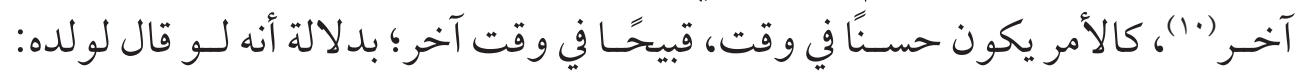

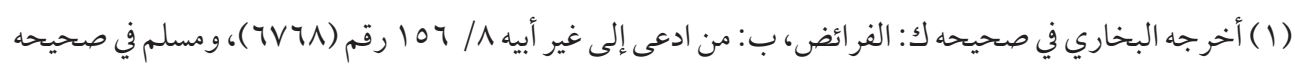

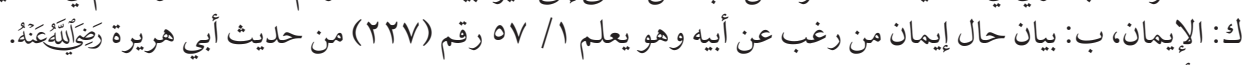

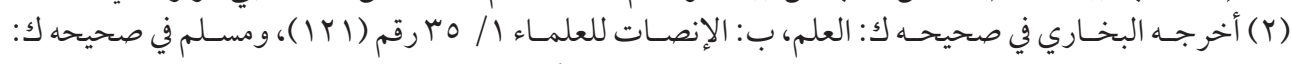

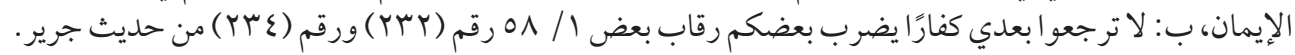

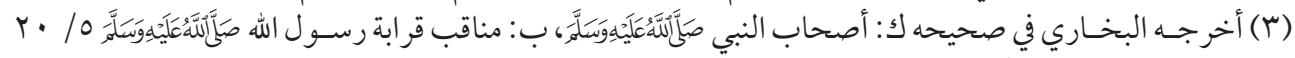

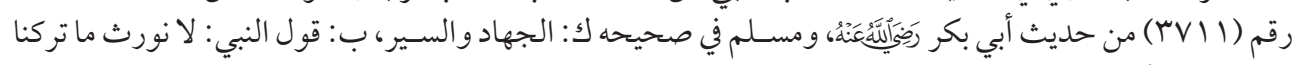

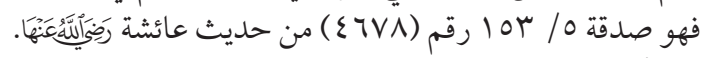

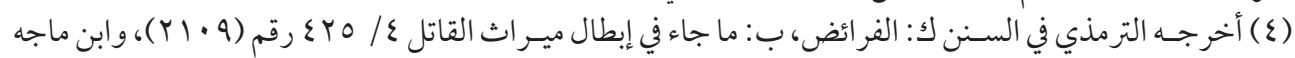

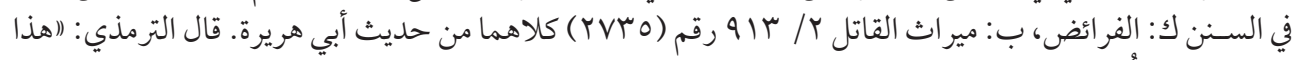

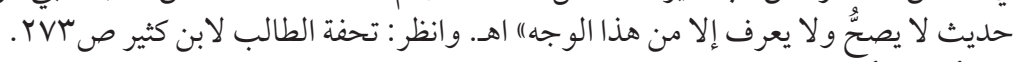

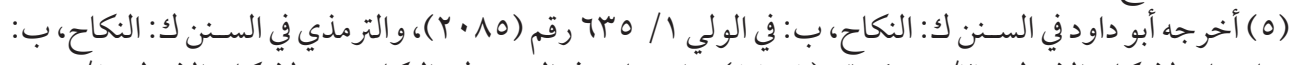

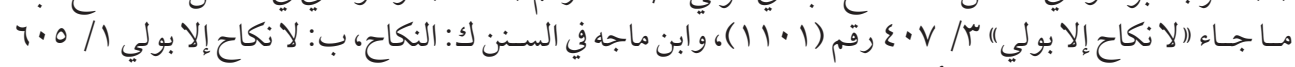

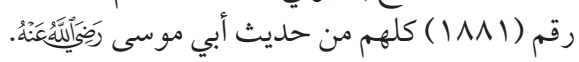

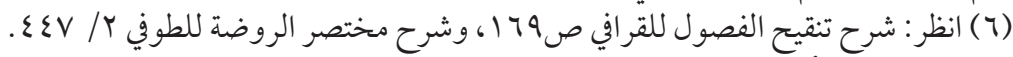

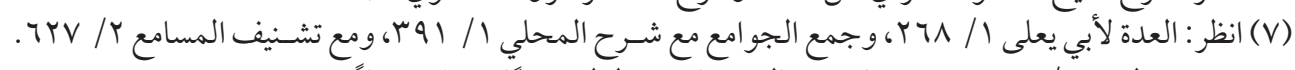

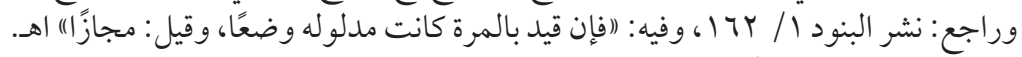

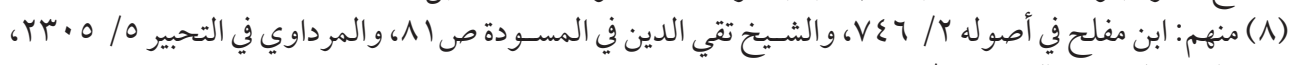

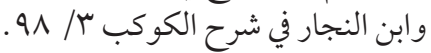

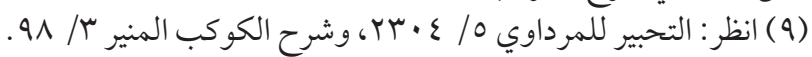

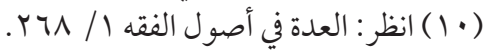




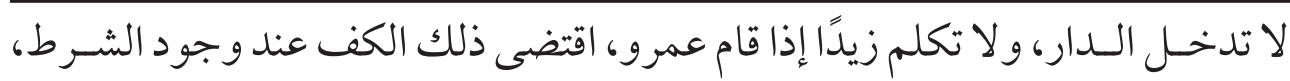
كالأمر المعلق بشرط يقتضي وجوده عند وجود الشرط، وعليه فإن النهي كالأمر تقييدًا و إطلاقةًا (1) وثانيهما: أن النهي إن قيد بالمرة أفاد التكرار، كالنهي المطلق سواء بسو اء.

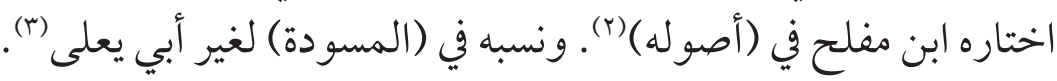

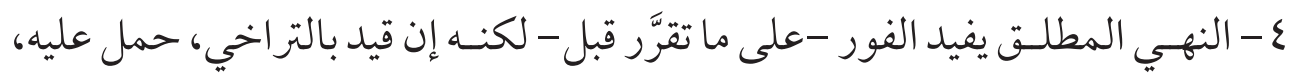

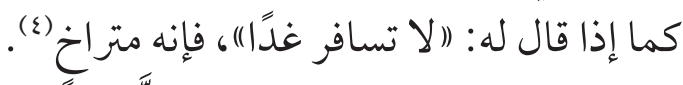

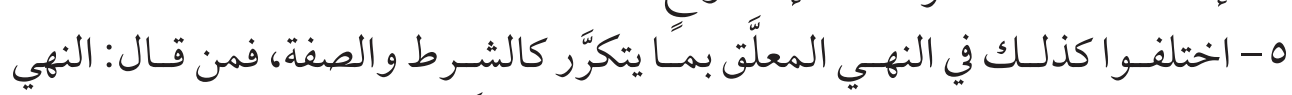

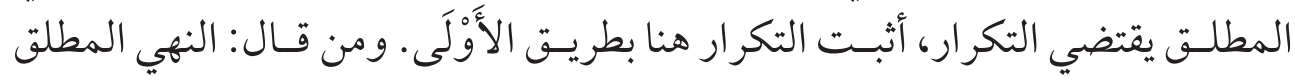

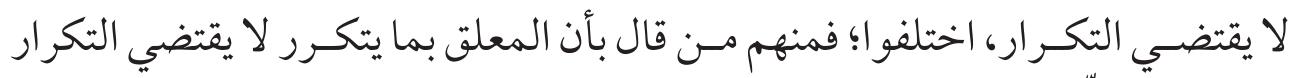

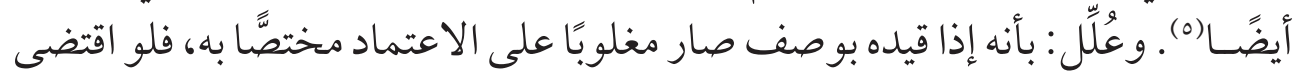

التكرار مع فهم تعدده كان كالأمر (ج).

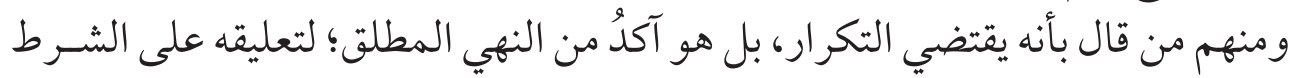

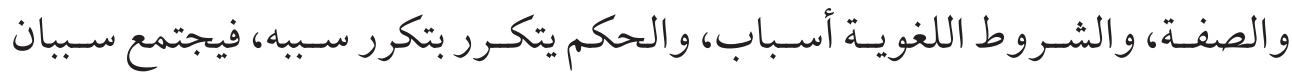

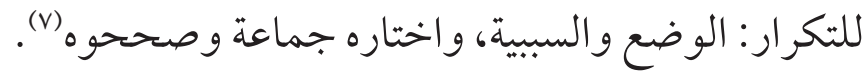

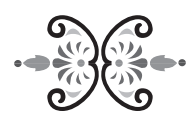

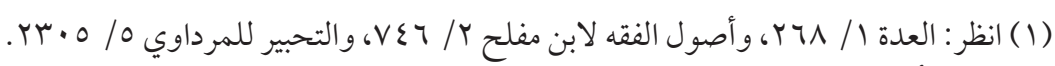

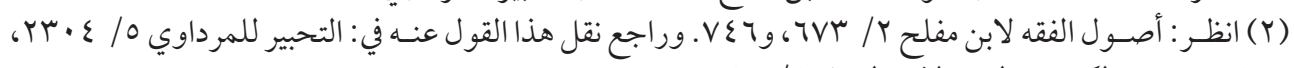

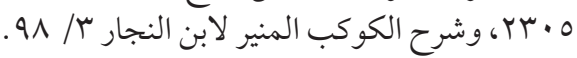

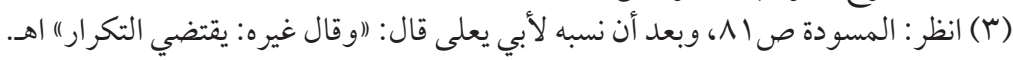

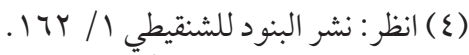

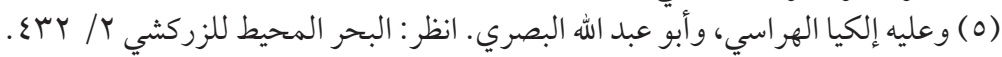

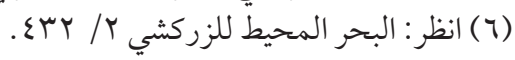

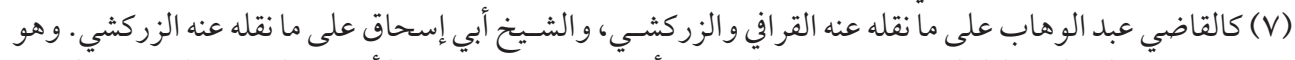

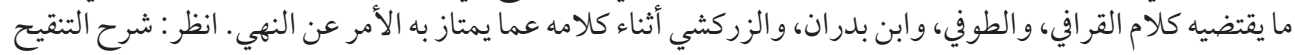

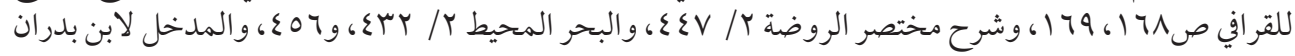
صن للعراف 


\section{المسألة الثامنة:}

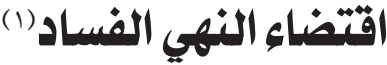

الفساديقابل الصحَّة، وهي تختلفُ باختلاف العبادات و المعاملات؛ فصحة المعاملات

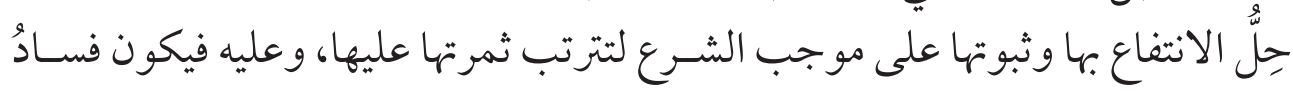
المعاملات معناه عدم حل الانتفاع بها مع عدم ترتب الثب الثمرة عليها.

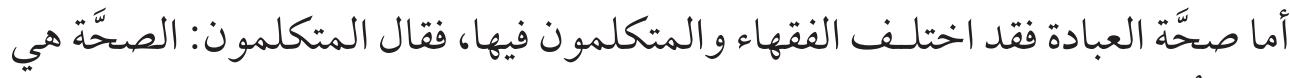
مو افقة أمر الشـارع في ظن المكلف لادة فئل في نفس الأمر . وقـال الفقهاء: وقوع الفعل كافيًا

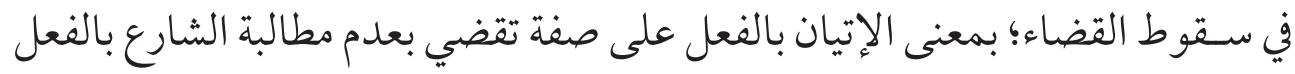

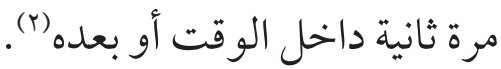

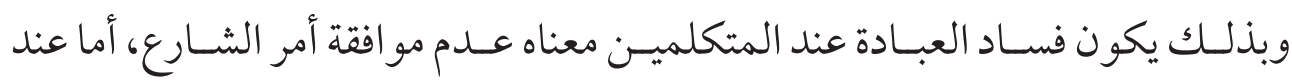

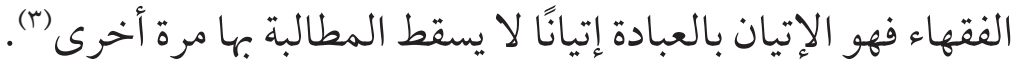

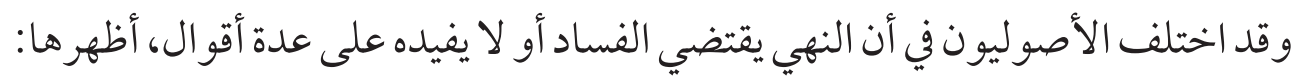

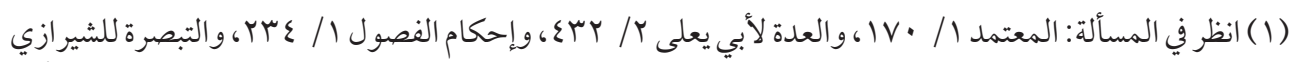

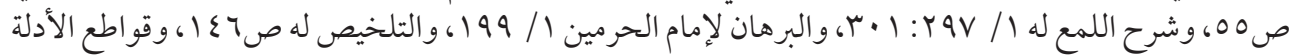

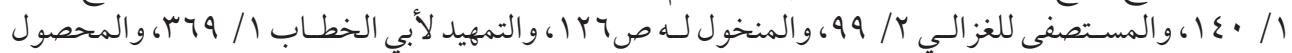

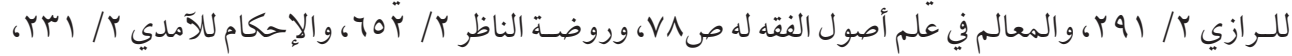

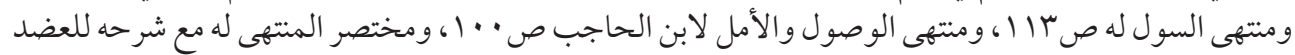

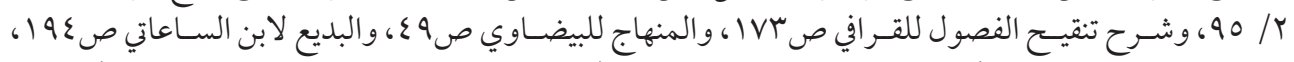

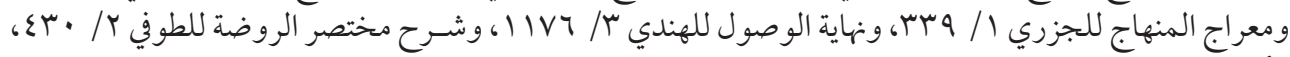

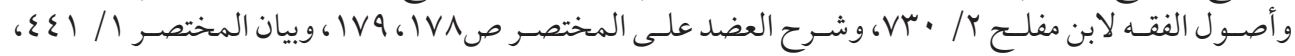

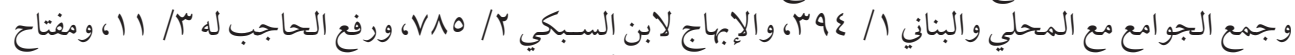

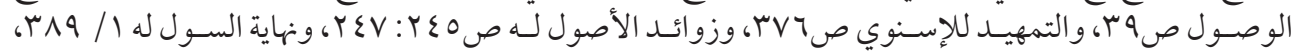

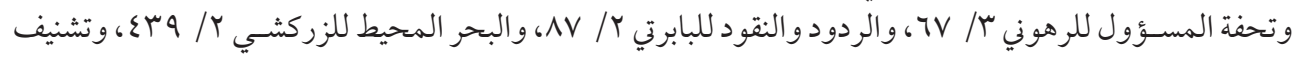

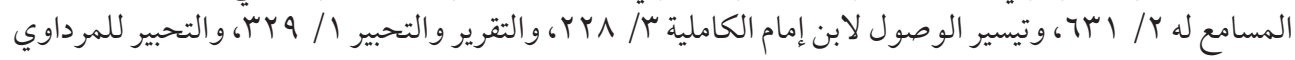

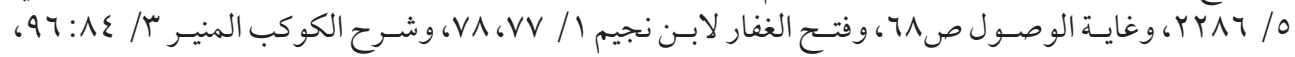

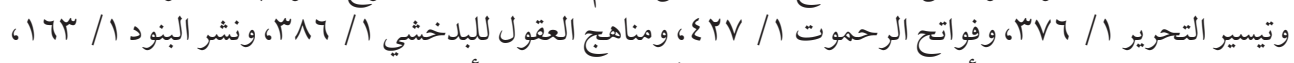

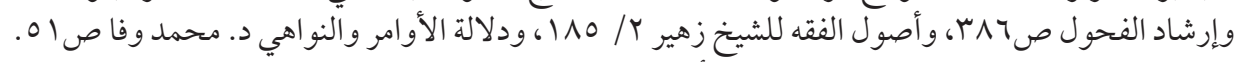

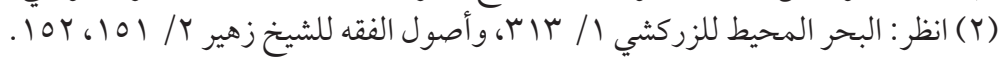

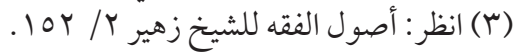


أن النهي يقتضي فساد المنهي عنه مطلقًا.

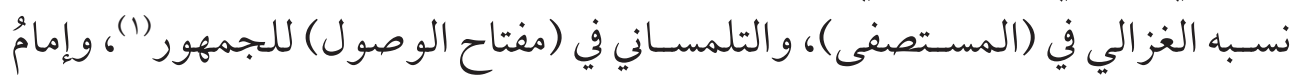

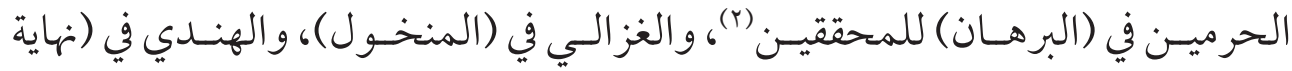

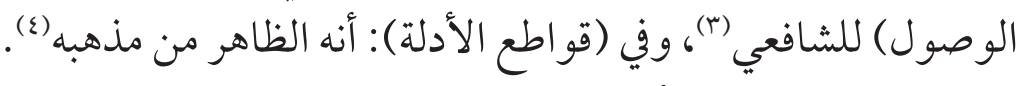

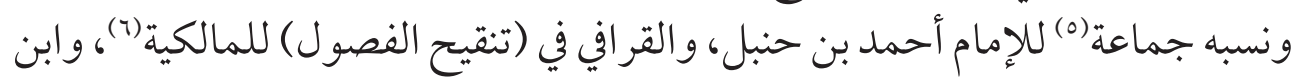

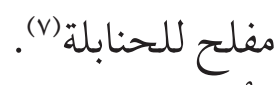

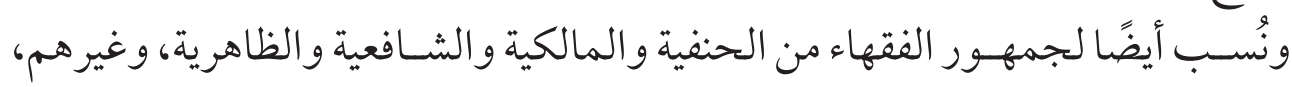

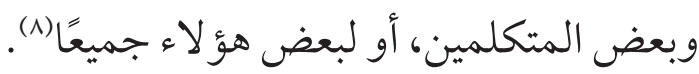

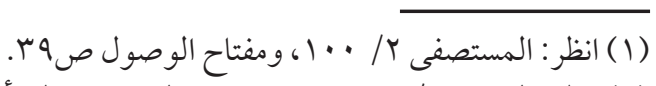

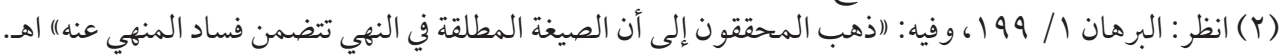

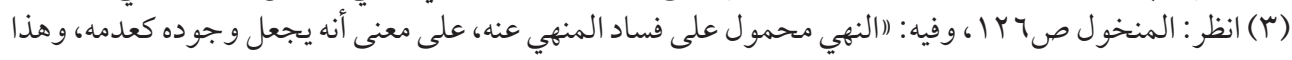

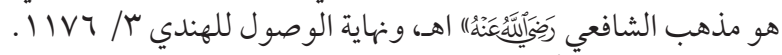

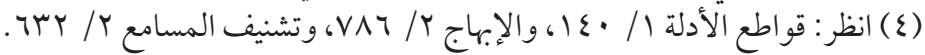

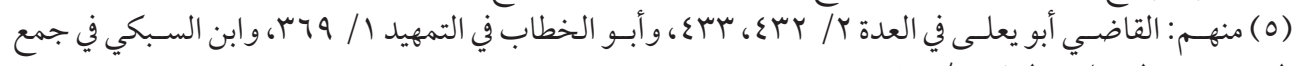

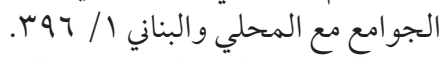

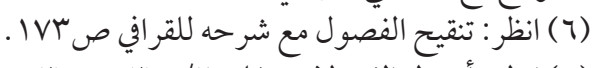

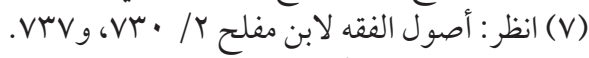

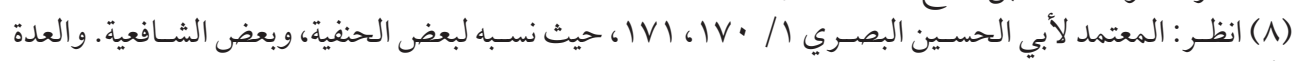

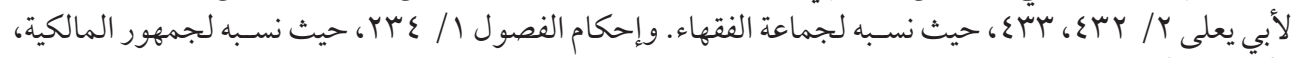

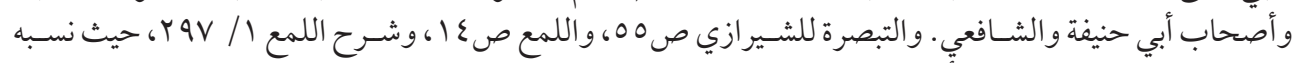

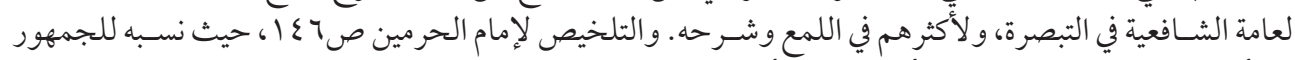

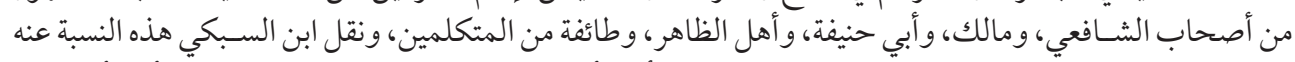

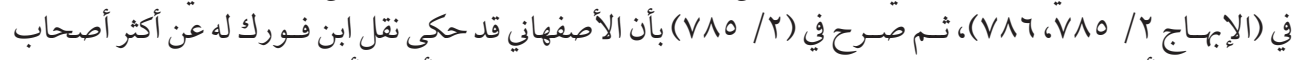

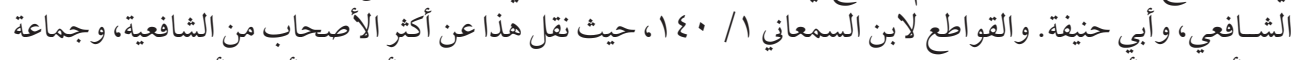

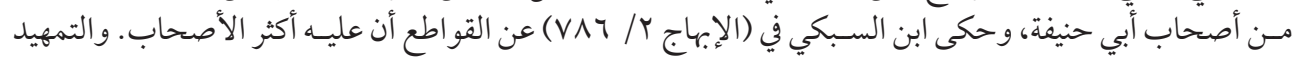

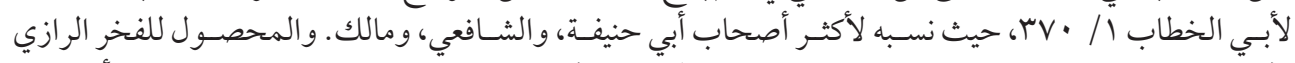

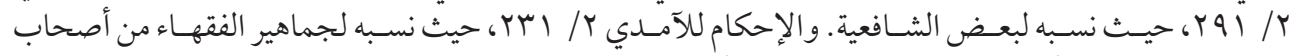

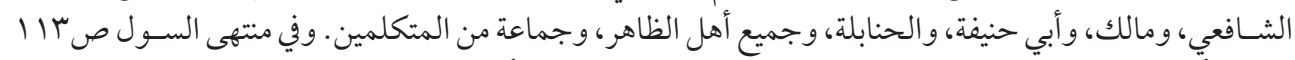

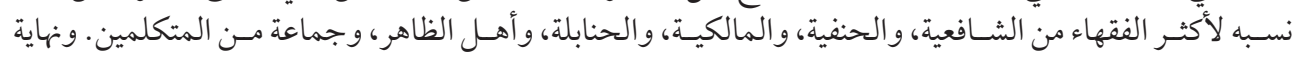

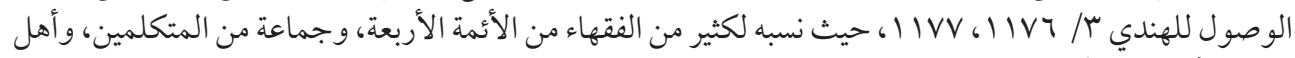

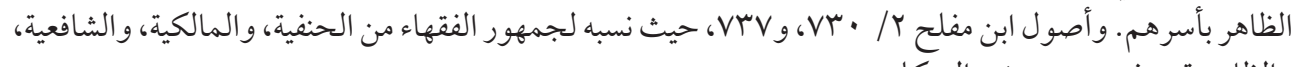
والظاهرية، وغيرهم، وبعض المتكلمين. 


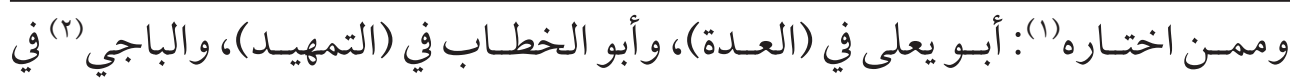

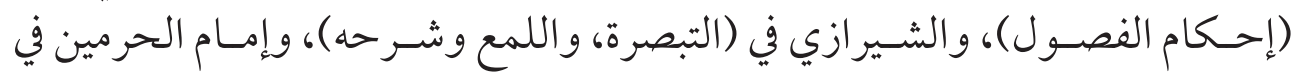

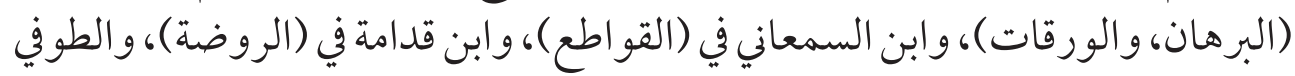

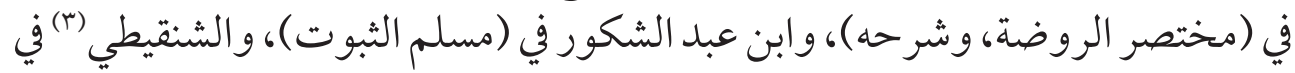

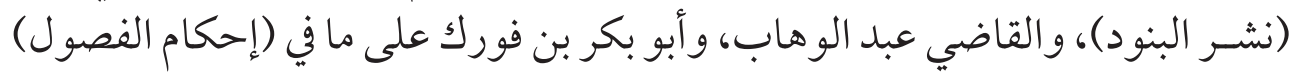

و اختاره أيضًا: ابن الحاجب في (مختصريه)، و المرداوي في (التحرير وشرحه التحبير)،

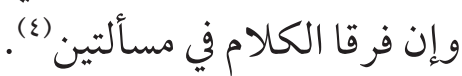

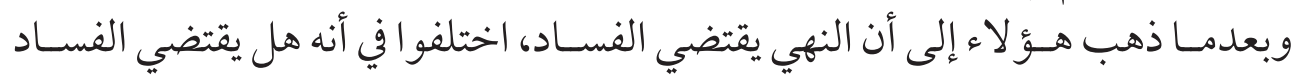

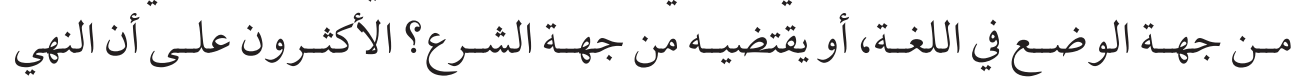

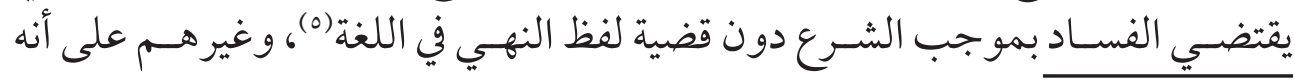

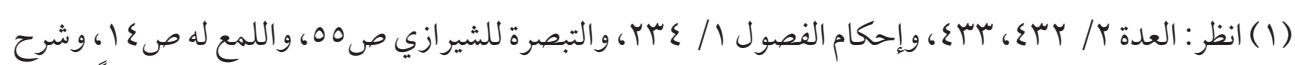

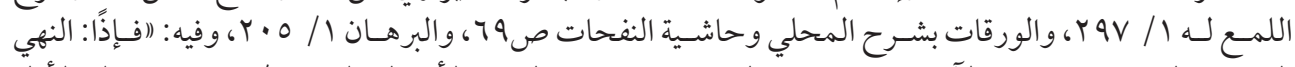

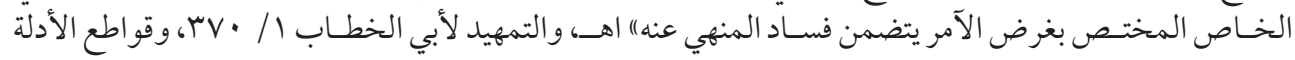

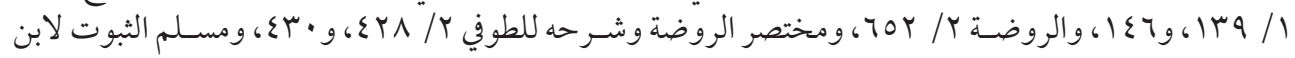

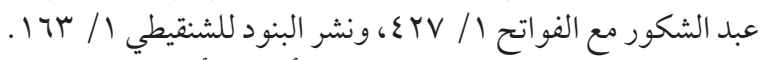

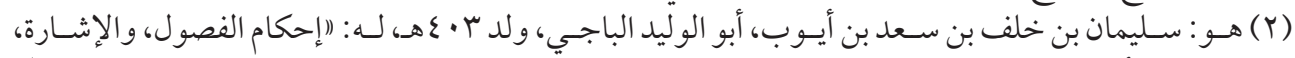

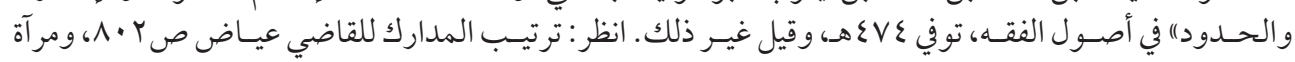

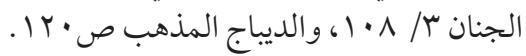

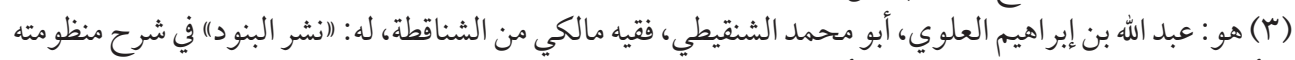

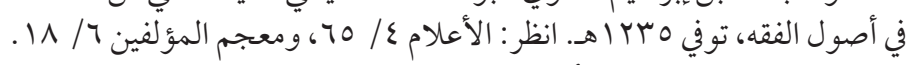

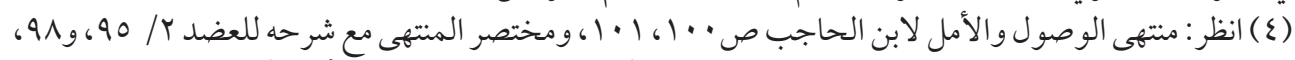

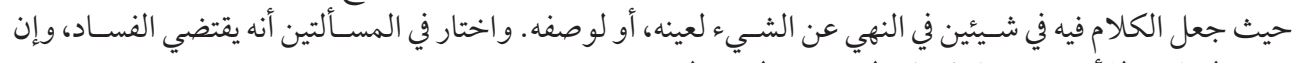

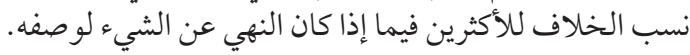

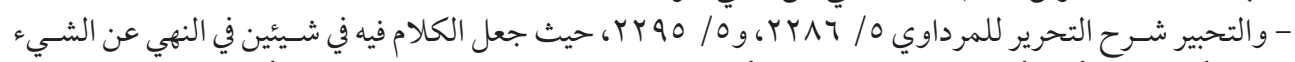

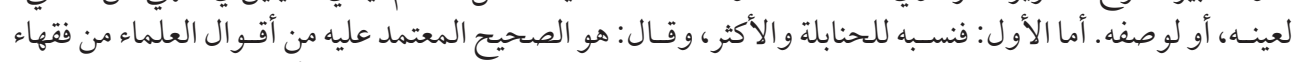

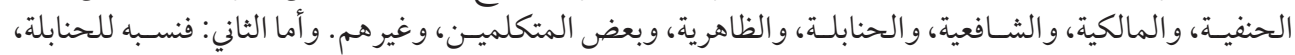

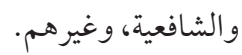

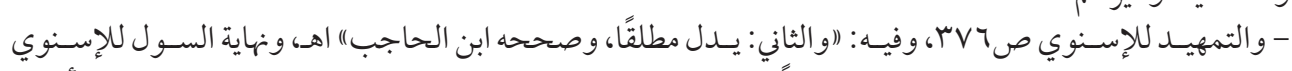

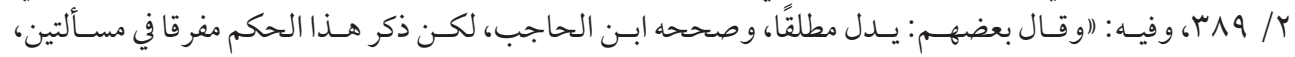

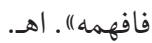

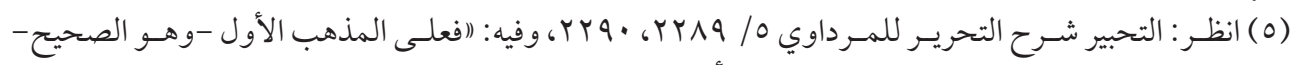

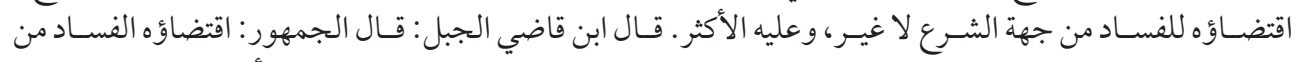

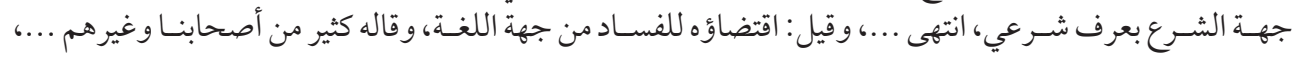




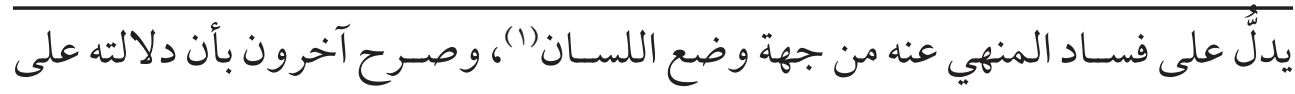

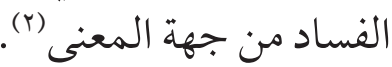
القول الثاني: أن النهي لا يقتضي فساد المنهي عنه مطلقًا.

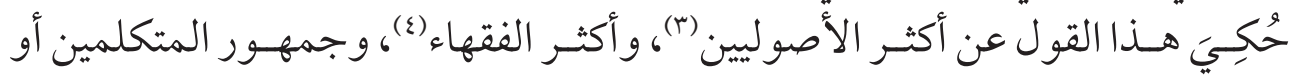

عامتهم (0)

وقيـل: اقتضاؤه للفسـاد من جهة المعنسى، حكاه طائفة من الحنفيـة؛ لأن النهي دلَّ على قبح المنهـي عنه، وهو مضادّ.

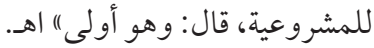

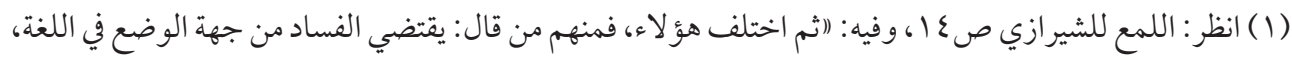

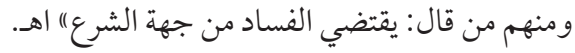

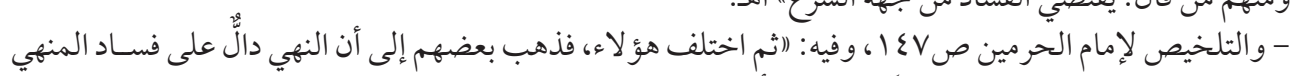

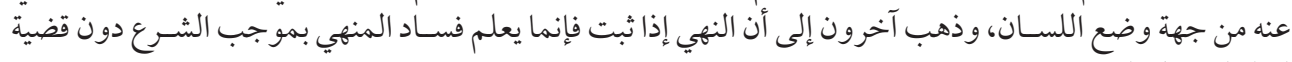

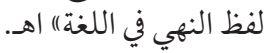

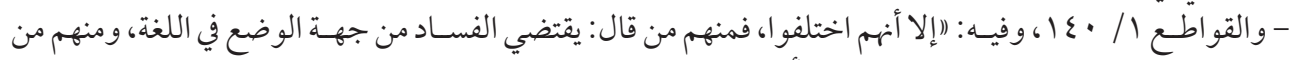

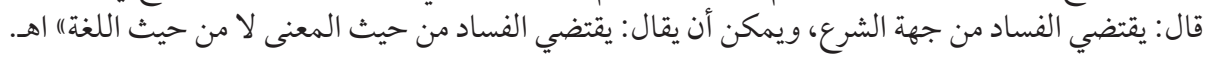

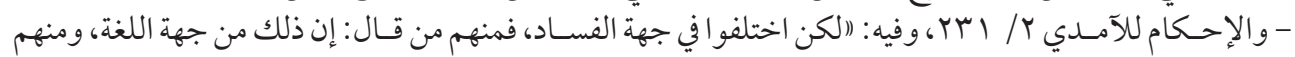

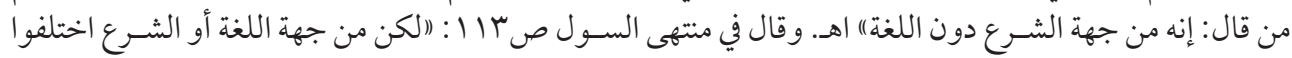
فيه |" اهـ.

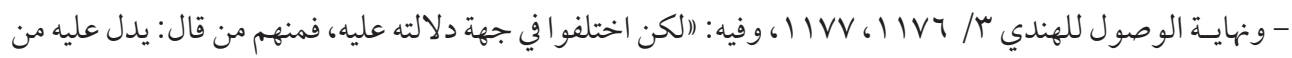

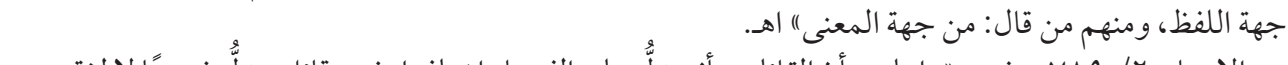

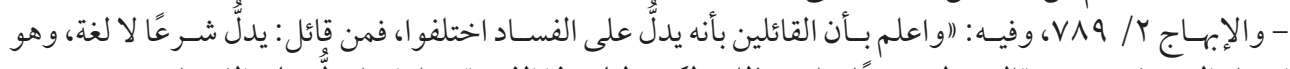

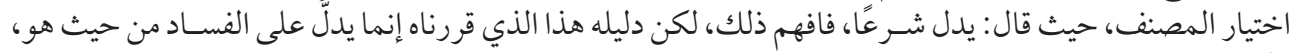

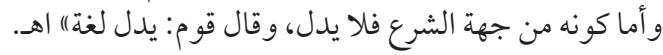

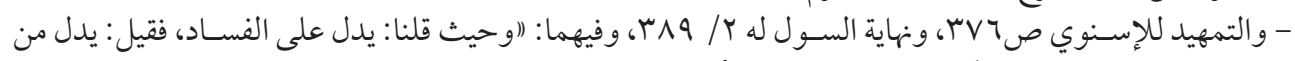

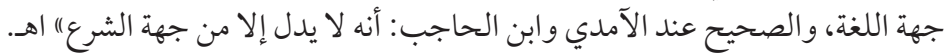

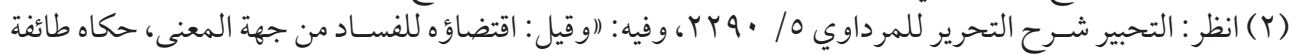

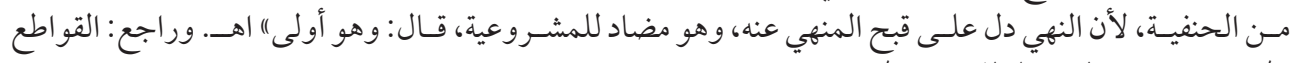

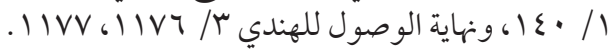

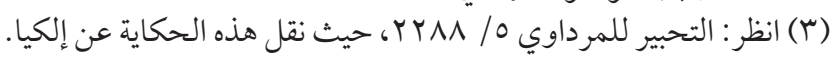

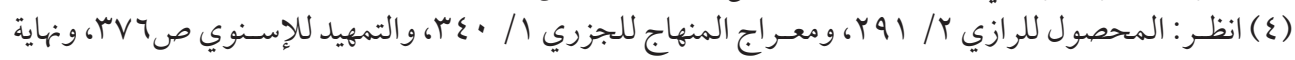

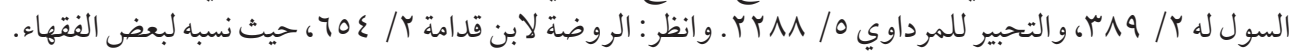

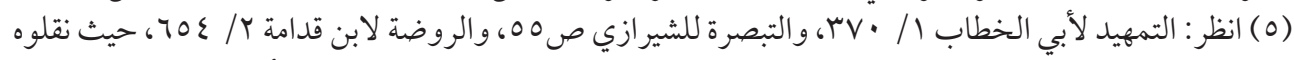

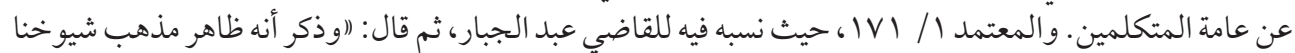

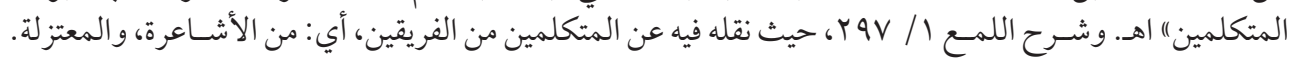

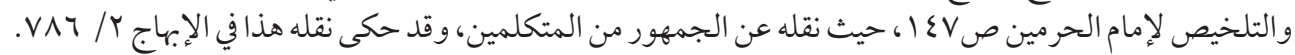

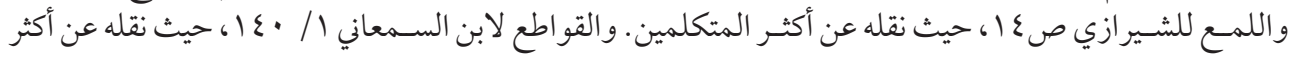

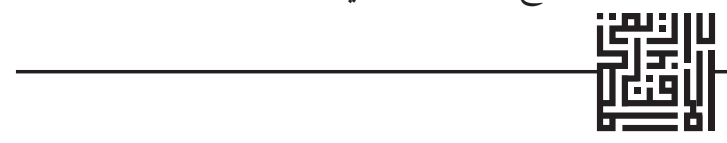


كما نسـب للمعتزلة(1)، أو بعضهم (r)، وللأشعرية(r). ونسبه الهندي في (نهاية الوصول) (كائ)

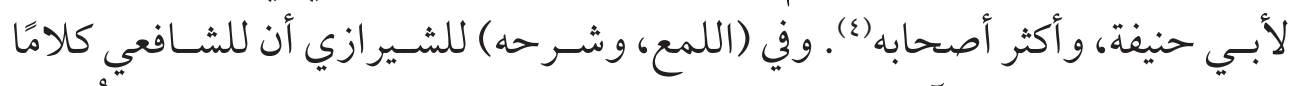

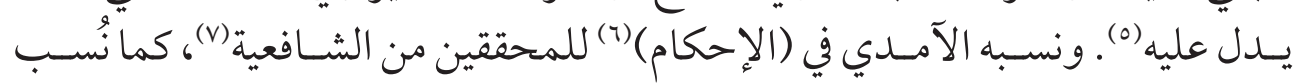

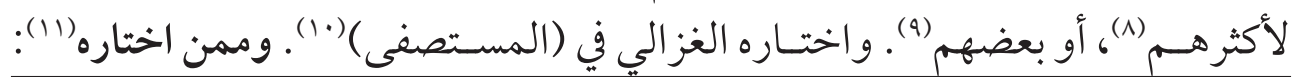

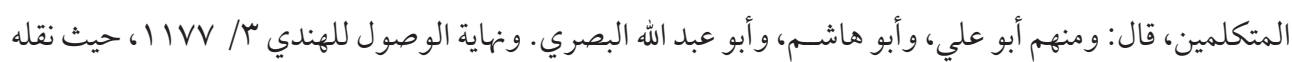

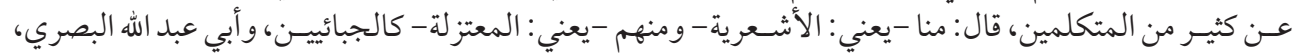

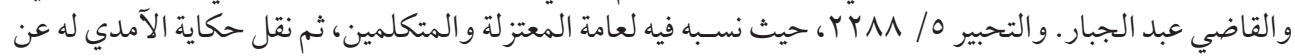

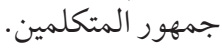

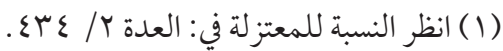

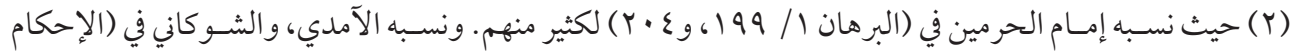

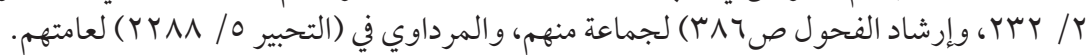

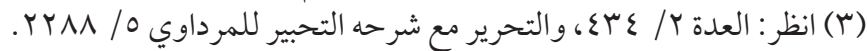

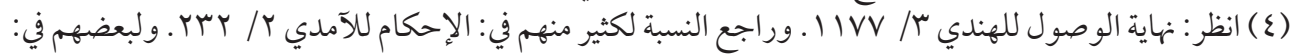

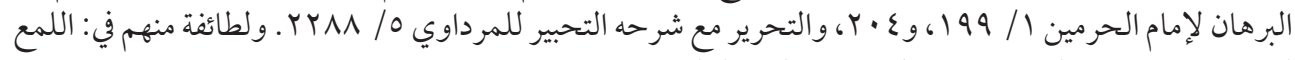

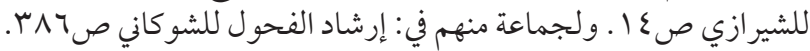

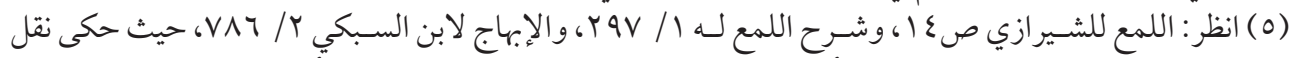

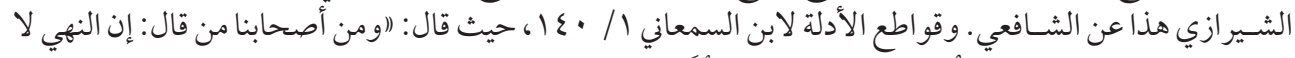

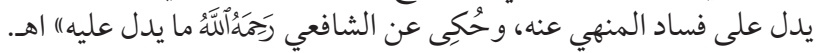

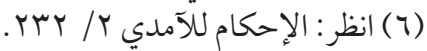

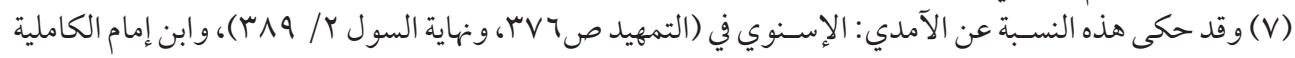

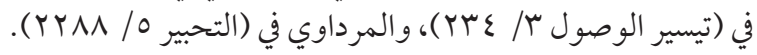

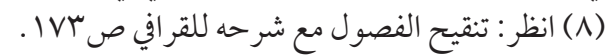

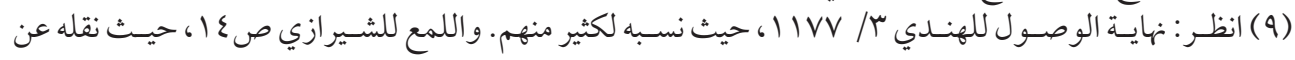

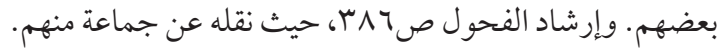

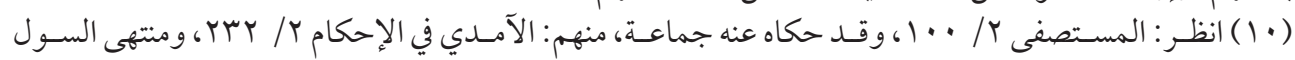

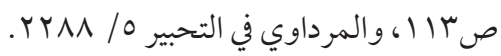

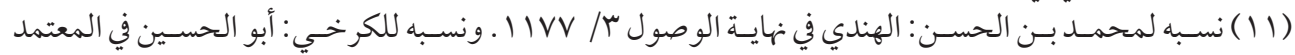

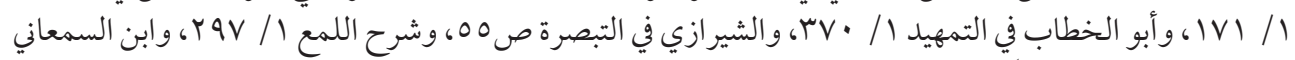

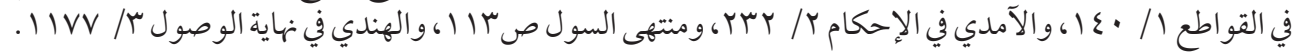

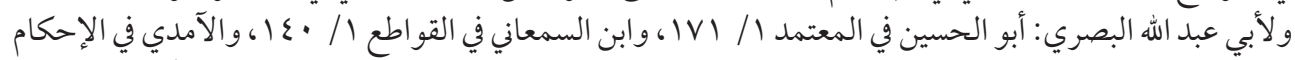

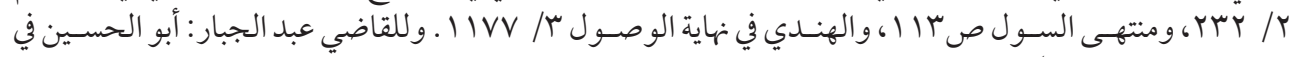

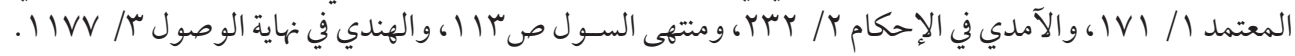

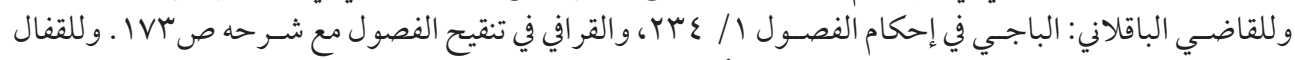

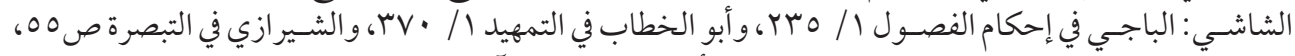

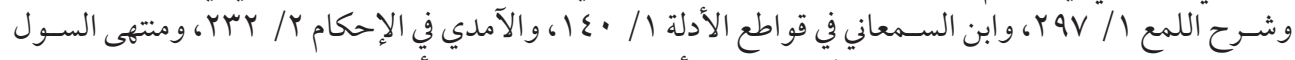

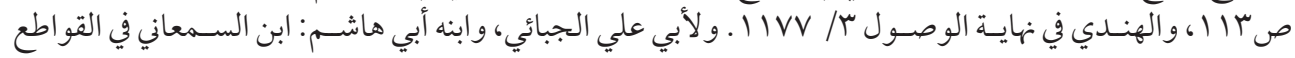

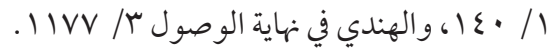


محمد بن الحسـن (1) و أبو الحسـن الكرخي (r) من الحنفية. و أبسو عبد الله البصري (r)"

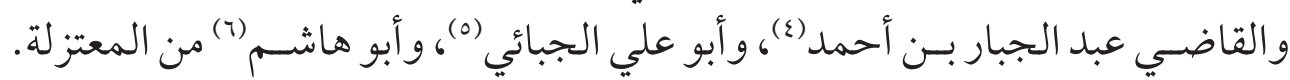

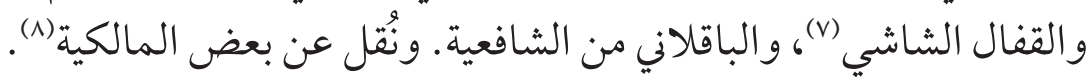
ونسـبه الآمدي في (الإحكام، و المنتهى) (9) لأبي الحسين البصري، و الحق أنه اختار في (المعتمد) أن النهي يقتضي فساد المنهي عنه في العبادات، دون العقود و الإيقاعات (·).

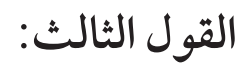

أن النهي يقتضي فساد المنهي عنه في العبادات، دون العقود و المعاملات و الإيقاعات.

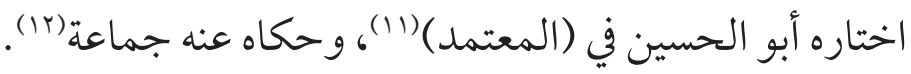

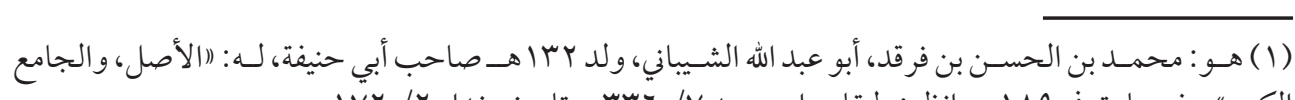

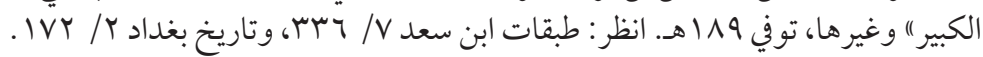

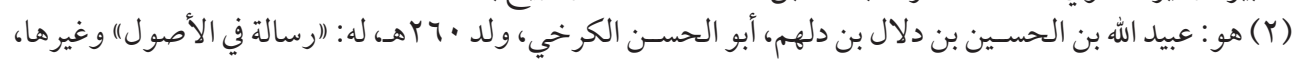

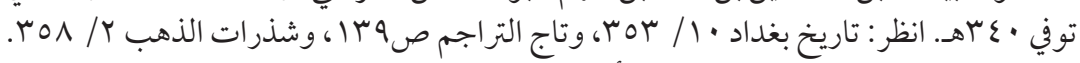

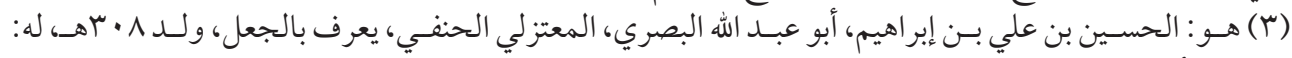

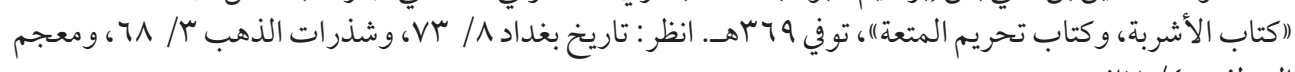

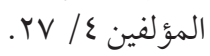

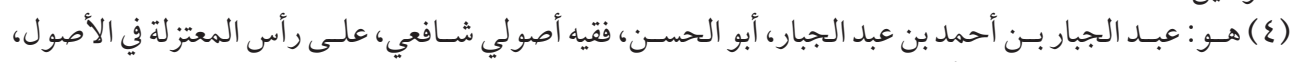

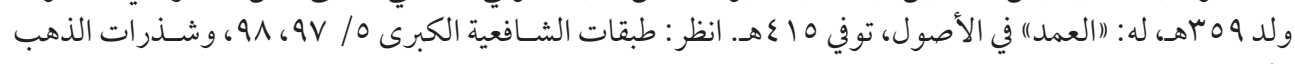
$r \cdot r / r$

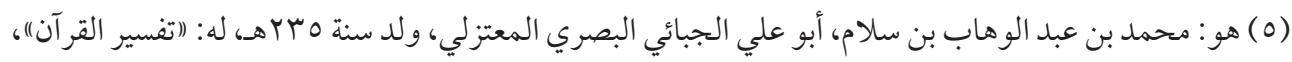

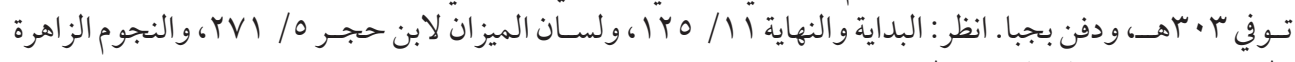

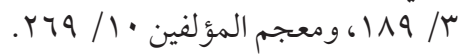

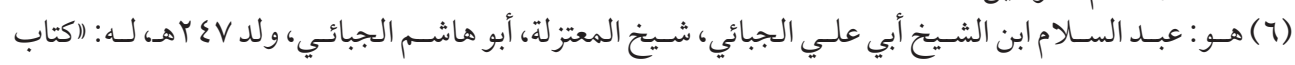

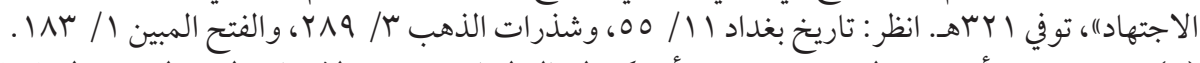

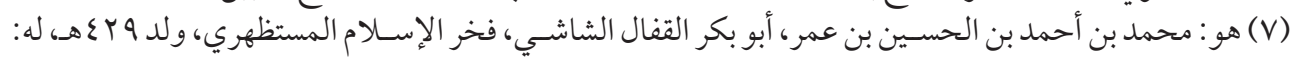

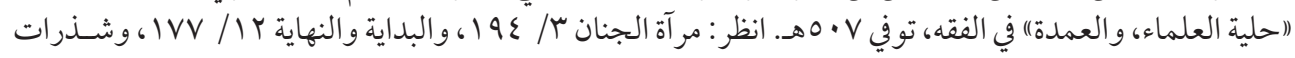

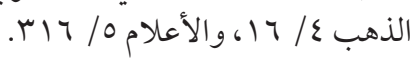

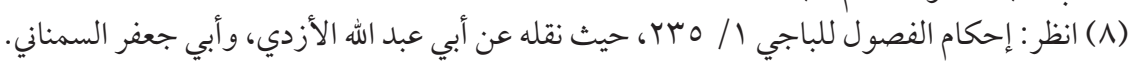

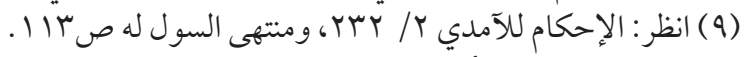

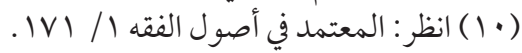

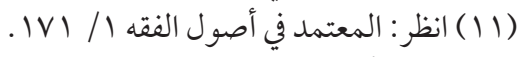

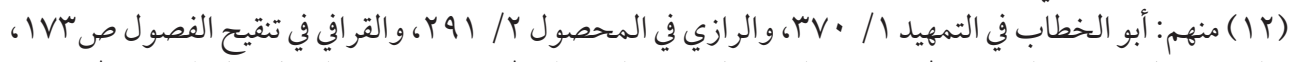

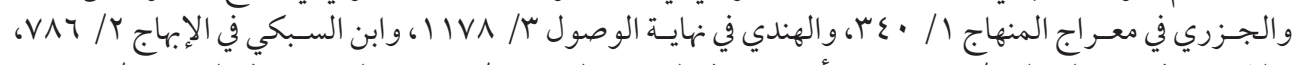

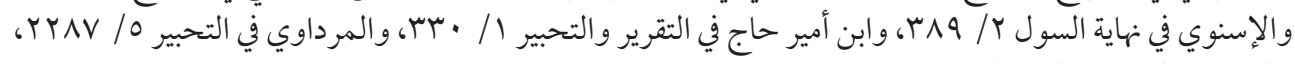

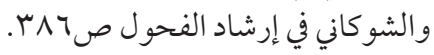


كما اختـاره الرازي في (المحصول)، وفي أول المســألة في (المعالم)(1)، وتابعه صاحبا

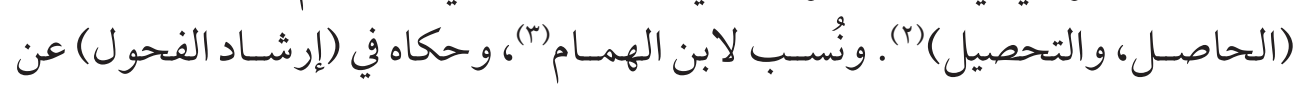

آخرين (ع) آناصن.

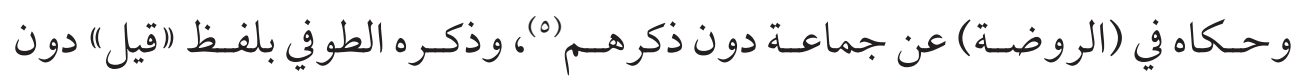
تصريح بالقائل (ج). ونسبه الهندي في (نهاية الوصول)، وابن أمير حاج (v) في (التقرير و التحبير)، و المرداوي

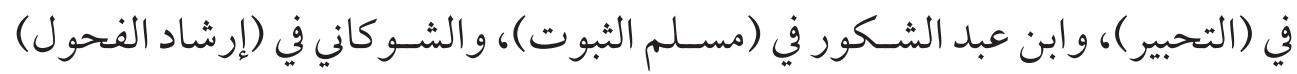
للغز الي (^). و الذي في (المستصفى) أنه لا يقتضي الفساد عنده (ه).

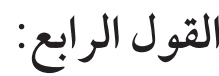

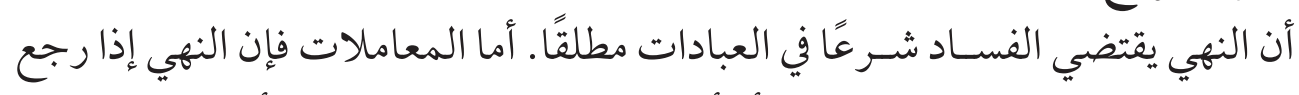
فيها إلى نفس العقد كبيع الحصاة، أو أمـر داخل فيه كبيع الملاقيح، أو لازم له له كالربا: اقتضى الفساد. وإن كان النهي لأمر مقارن كالبيع وقت النداء لم يقتضِي الفساد.

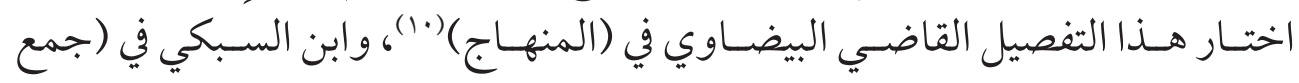

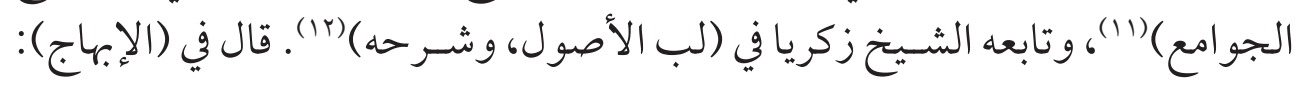

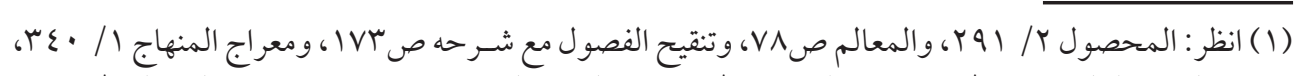

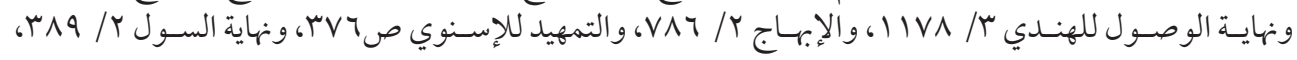

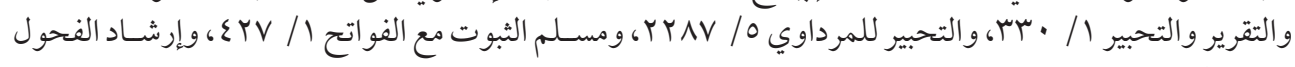
صזیr.

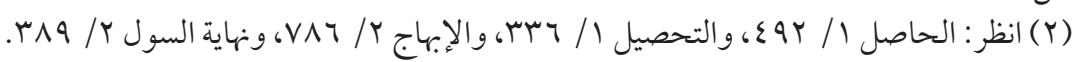

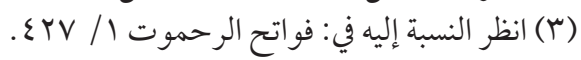

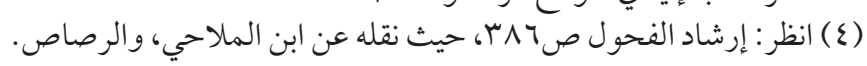

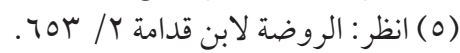

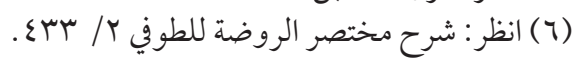

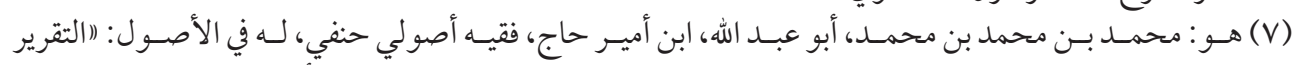

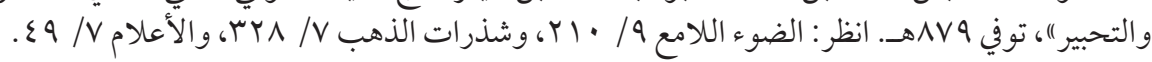

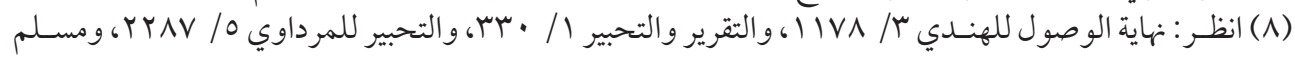

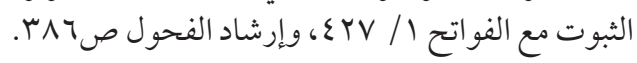

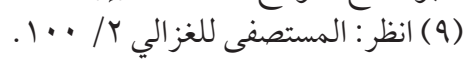

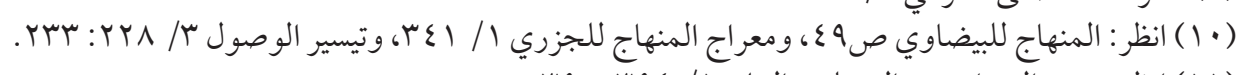

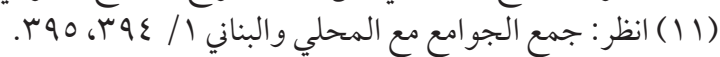

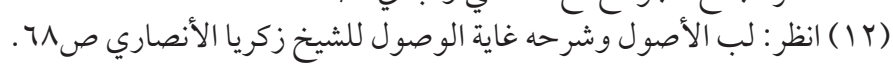




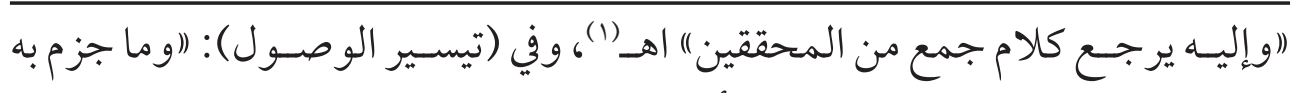

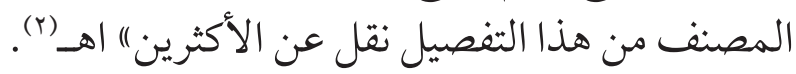

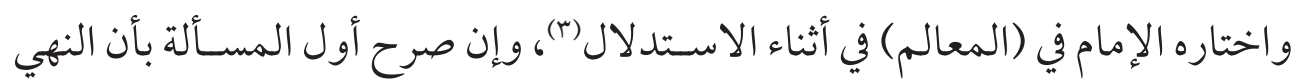

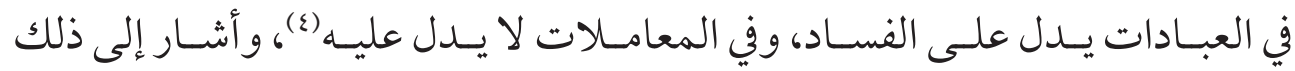
الإسنوي (0) في فنتبه.

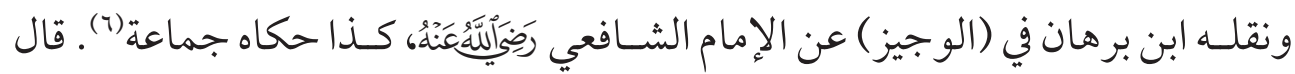

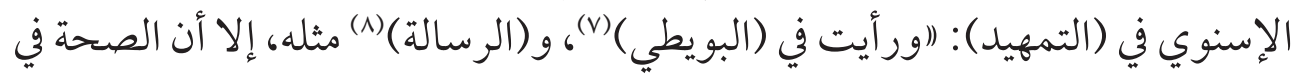
المقارن ذكرها في موضع آخر ") اهــ( ).

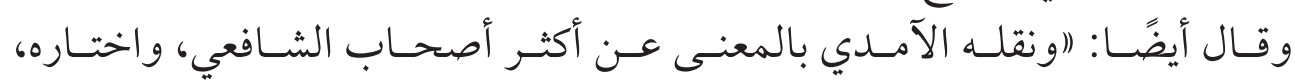

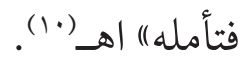

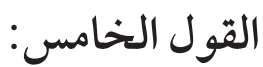
إن كان النهي عن الشـيء لمعنسى في عينه أوجب الفسـاد، وإن كان لمعنسى في غيره لا يوجب الفساد.

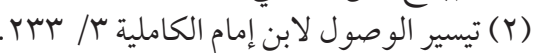

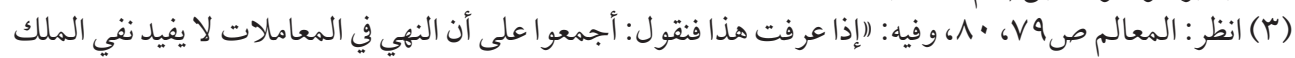

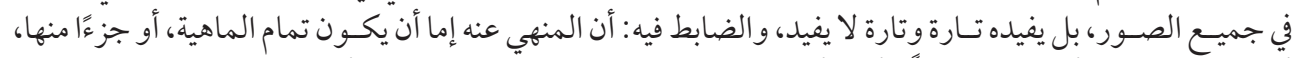

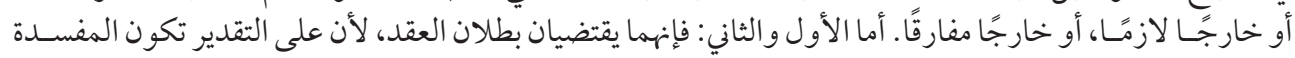

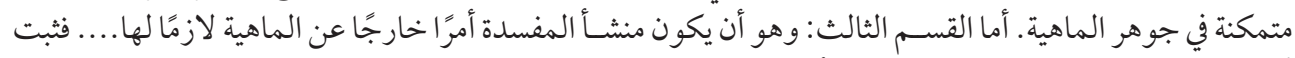

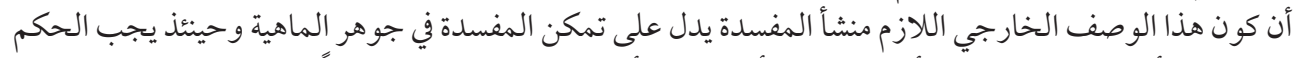

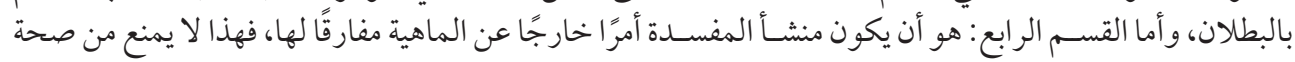

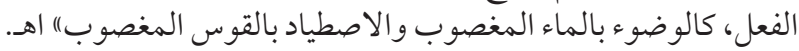

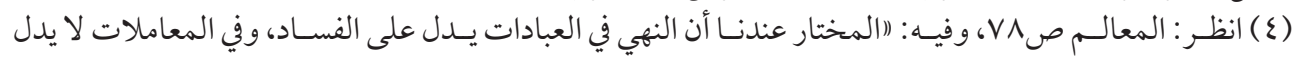

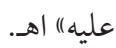

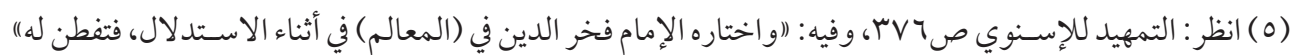

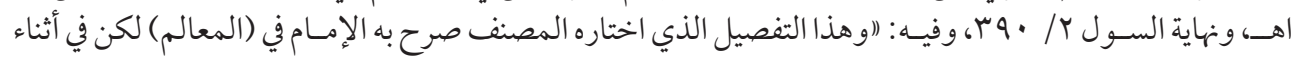

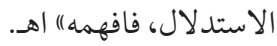

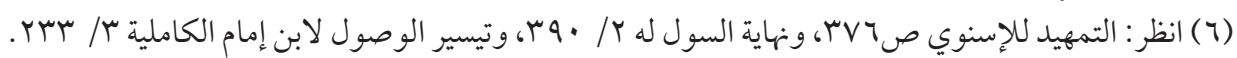

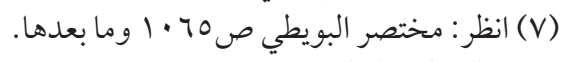

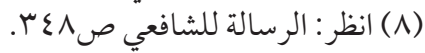

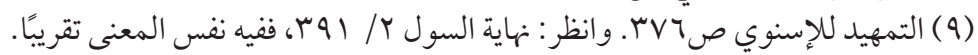

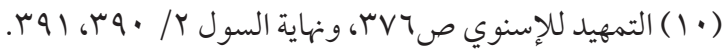

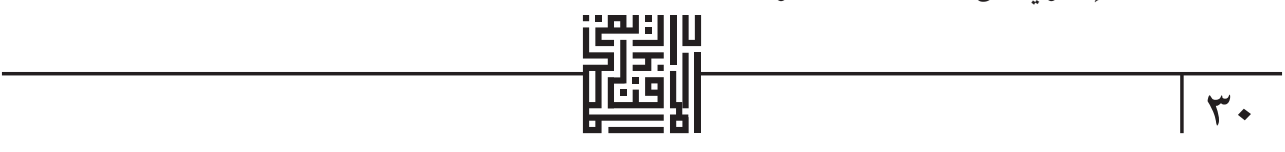




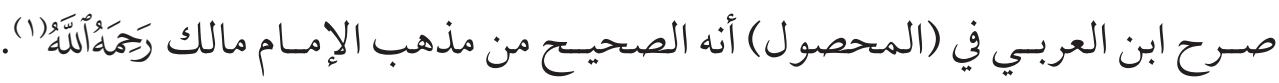

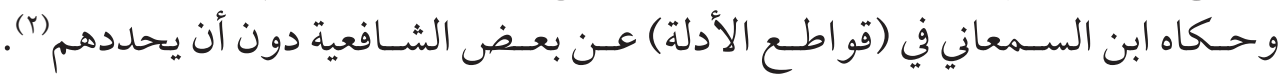

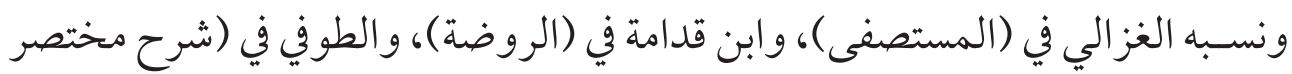
الروضة) لقوم دون ذكرهم (r).

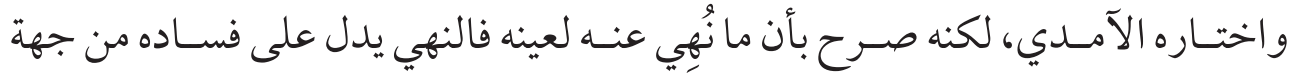

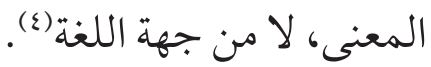
القول السادس: النهي لا يدل على الفساد مطلقًا، ويدل على الصحة.

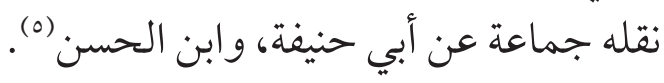

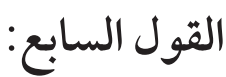
أن النهي عن الشيء إن كان لحق الله تعالى، فإنه يفسد المنهي عنه، وإن كان لحق العبد، فلا يفسد المنهي عنه. نسبه التلمساني في (مفتاح الوصول) لمذهب عند المالكية(7). الأدلة و المناقشات: الماته

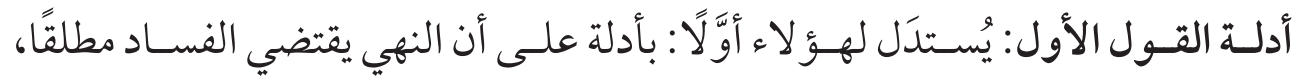

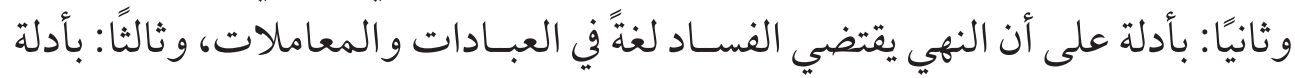

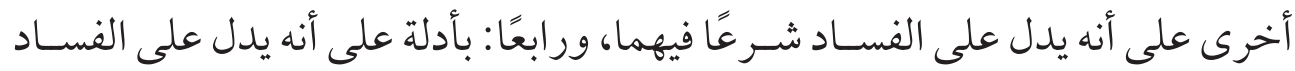

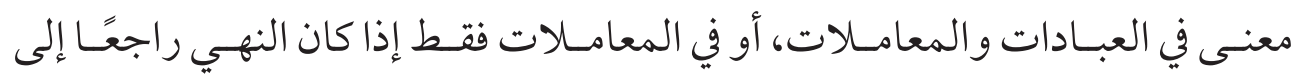

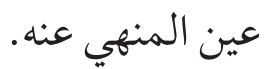

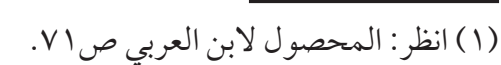

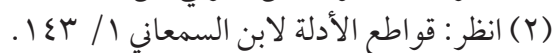

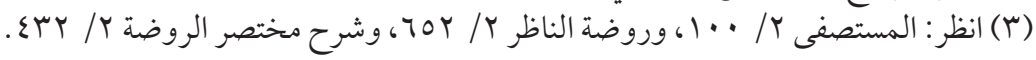

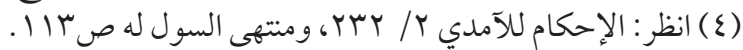

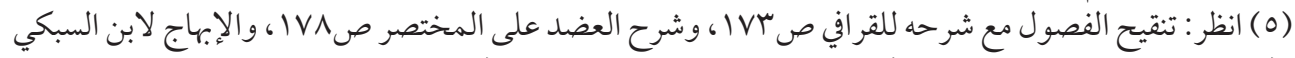

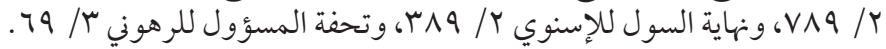

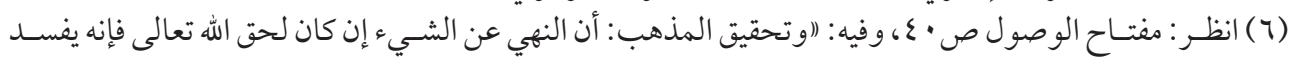
المنهي عنه، وإن كان لحق العبد فلا يفسد المنهي عنها) اهـ. الهـ. 
1أما أدلتهم على أن النهي يقتضي الفساد مطلقًا فمنها:

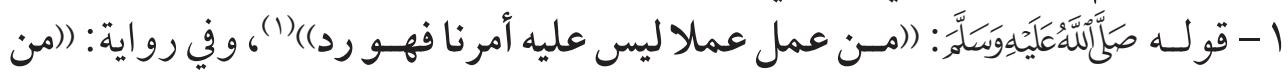

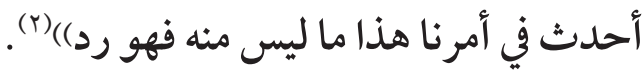

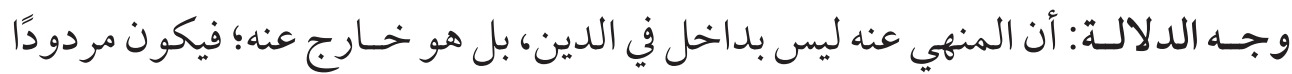

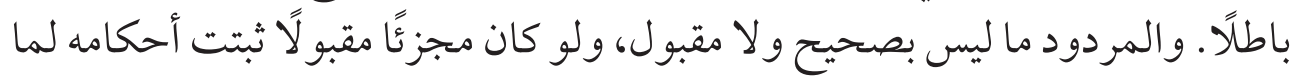
كان مردودًا (r)

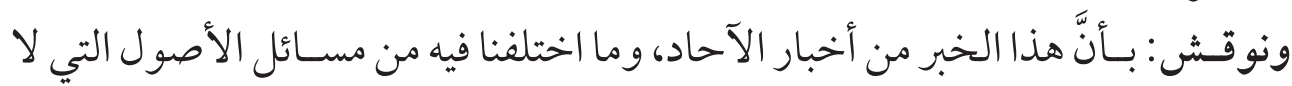

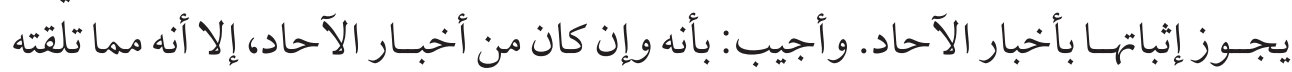

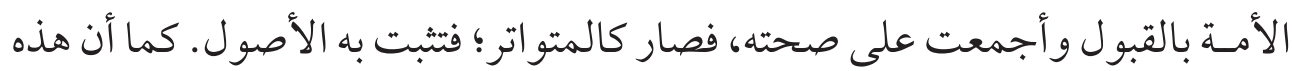

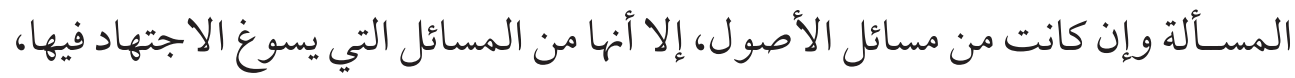

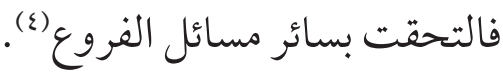

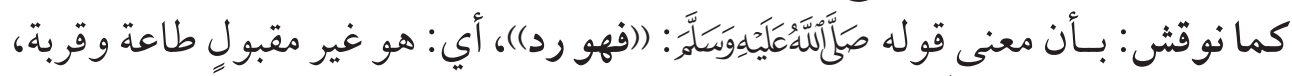

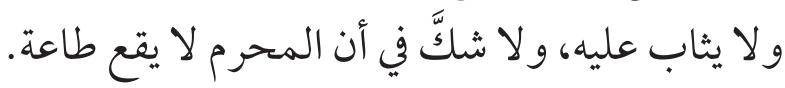

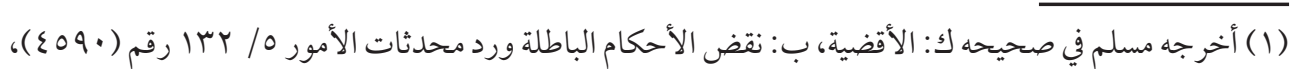

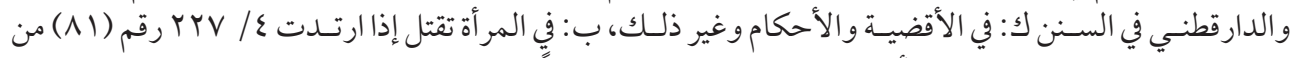

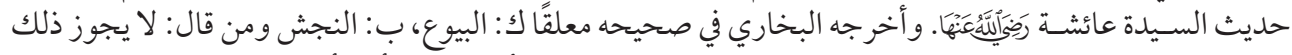

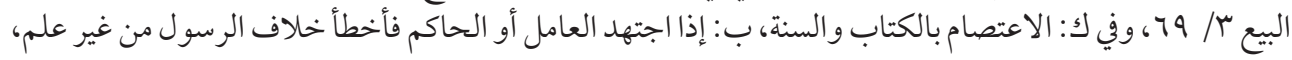

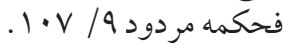

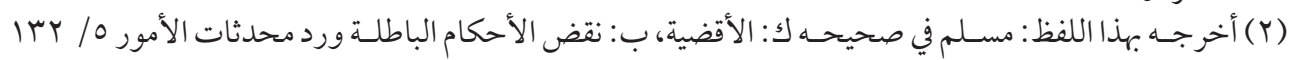

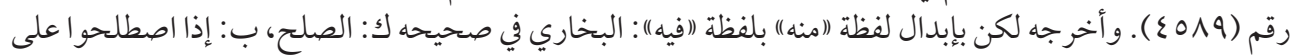

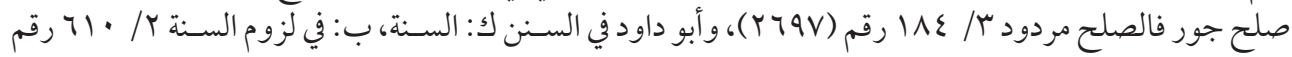

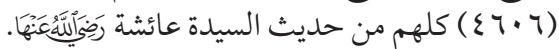

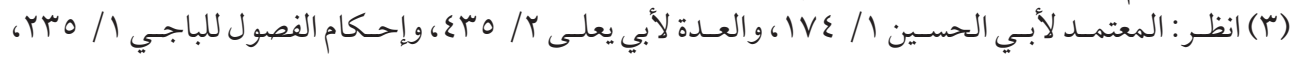

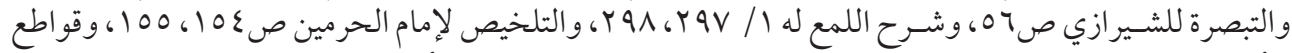

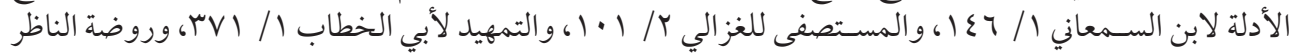

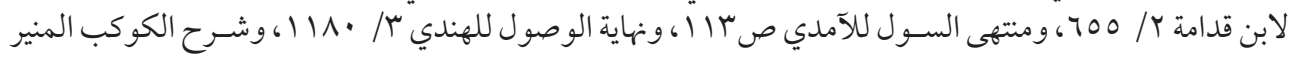

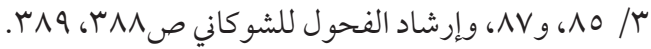

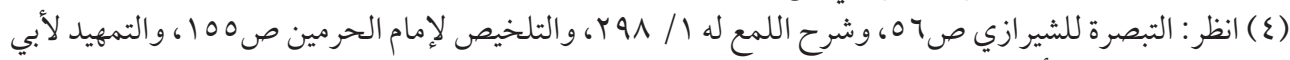

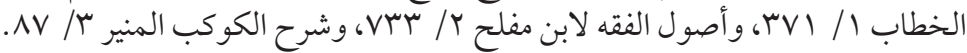


وأجيـب: بـأن الظاهر من قوله: ((رد)) أنه بمعنى الإبطـال و الإعدام، كما يقال: رد فلان

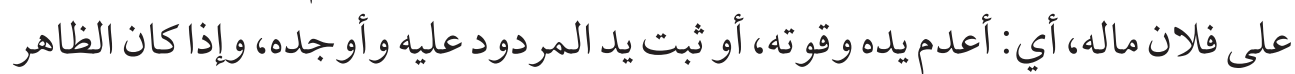

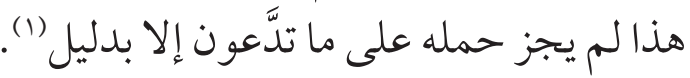

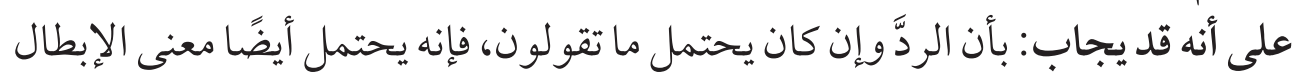

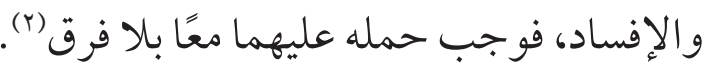

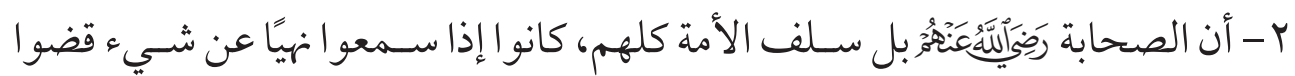

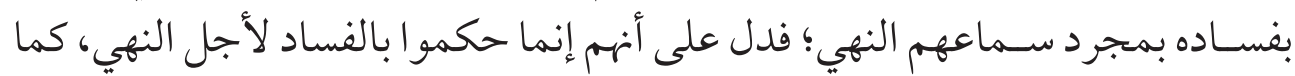

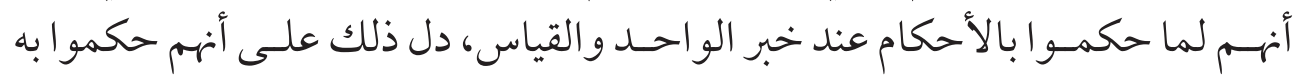
لأجل خبر الو احد والقياس، ومما حكمو ا بغساده لمجرد سماعهم النهي الشرعي عنه:

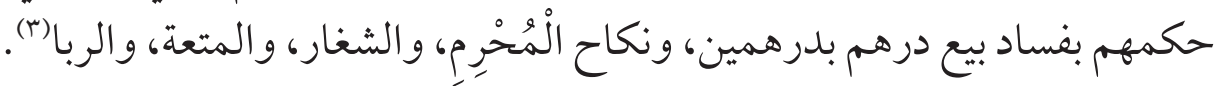

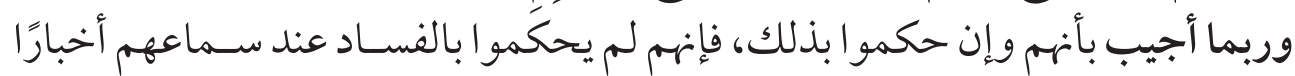

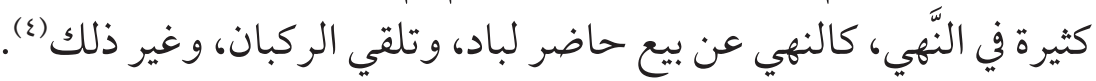

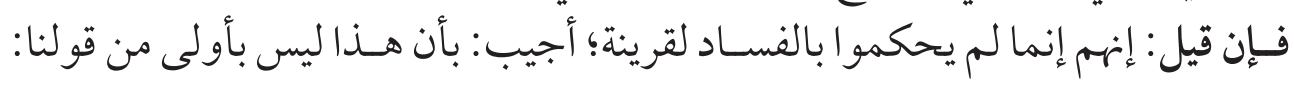

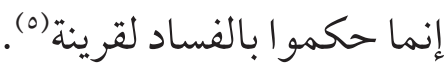

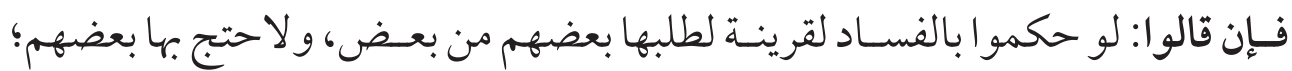

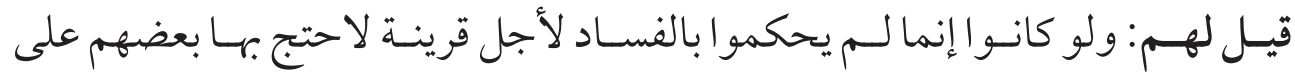

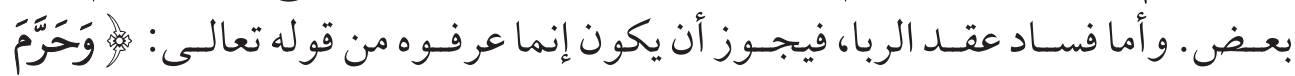

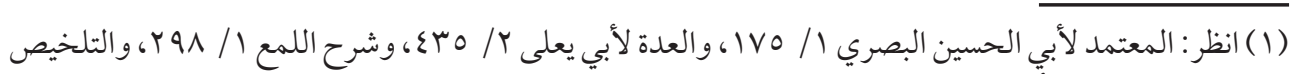

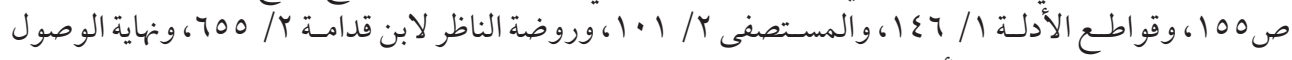

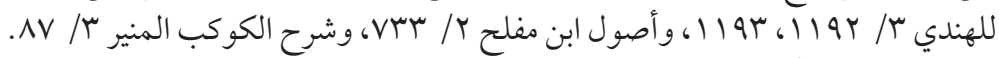

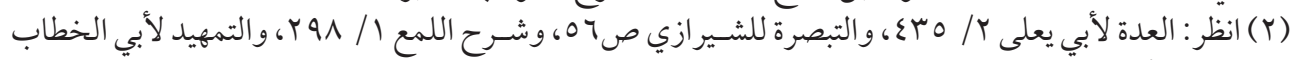
ا

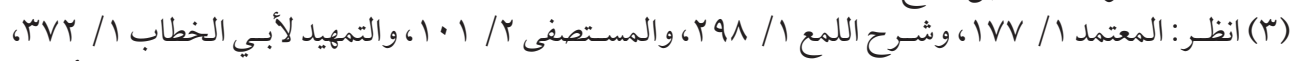

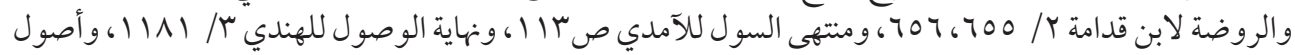

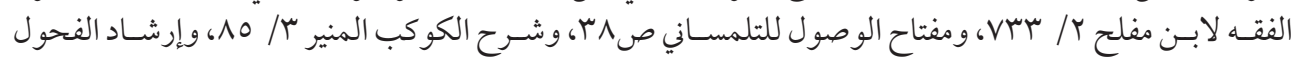

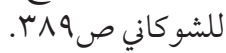

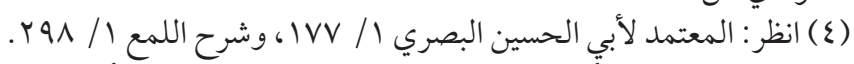

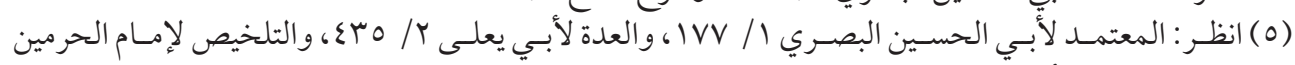

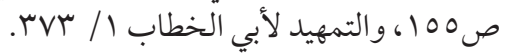




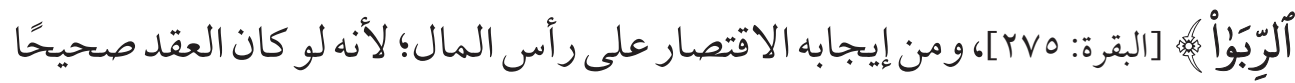

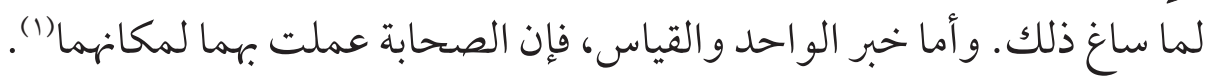

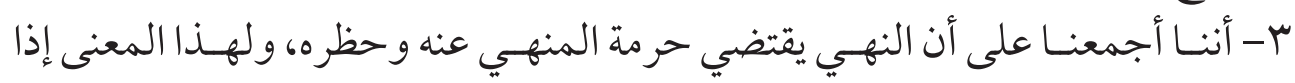

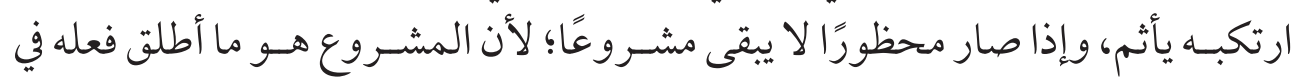

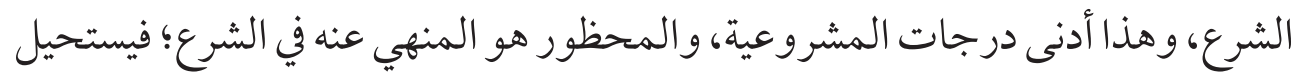

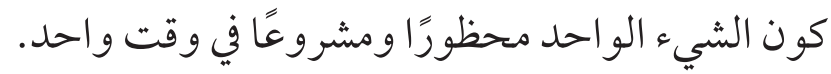

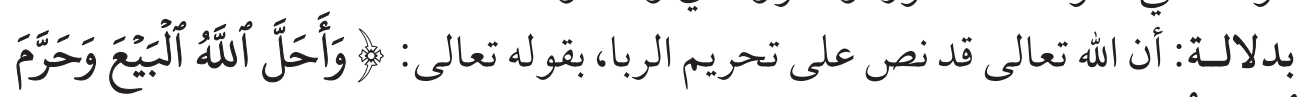

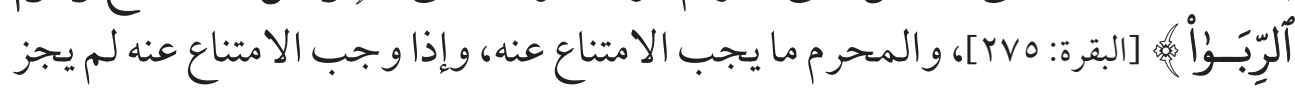

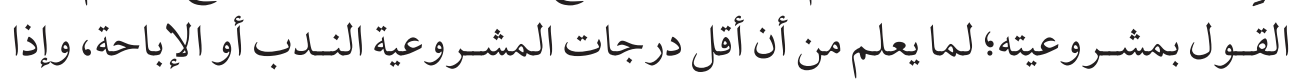

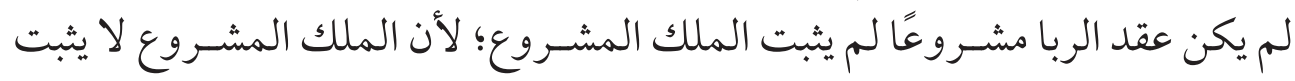

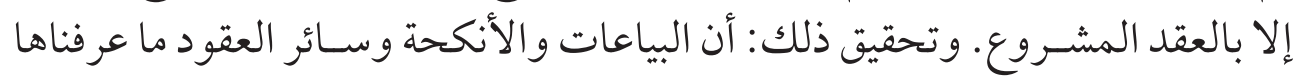

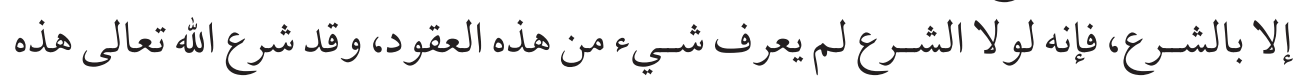

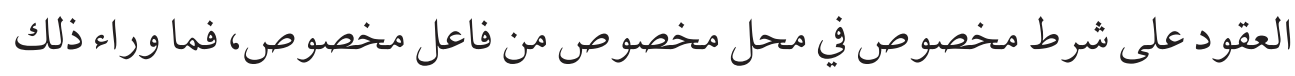

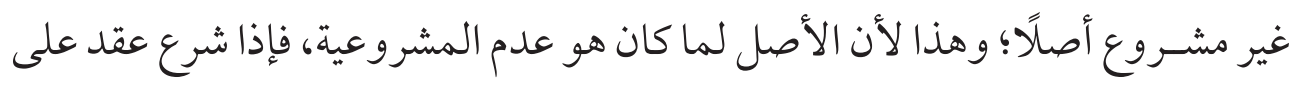

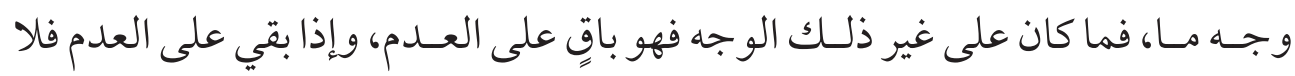
يصلحُ لثبوت حكم شرعي (ل).

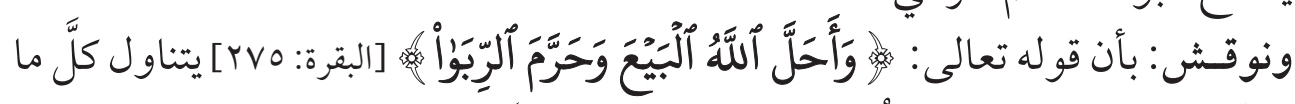

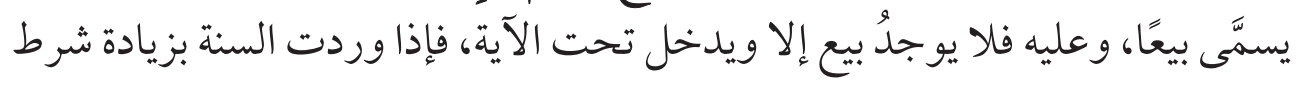

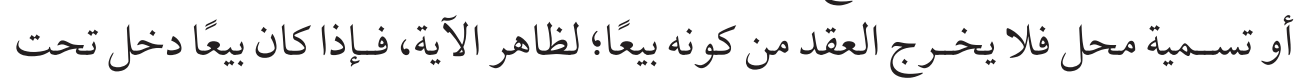
المشروعية.

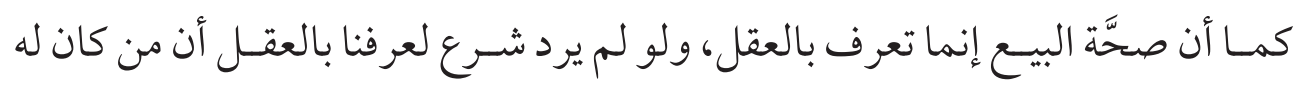

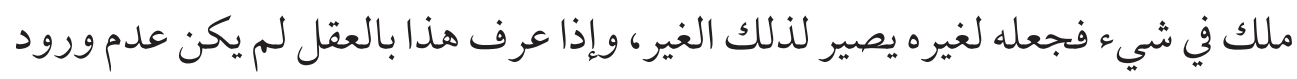
المشرع دليلًا على انعدامه.

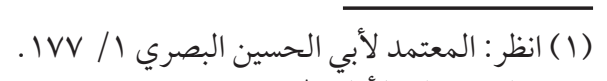

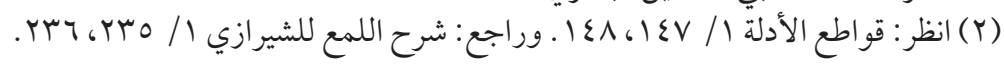




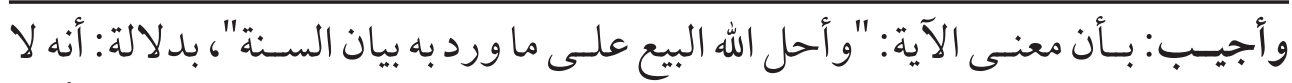

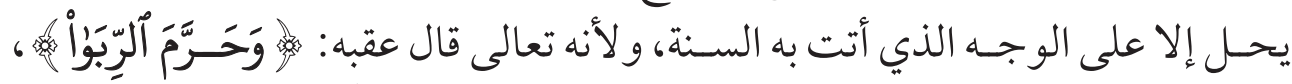

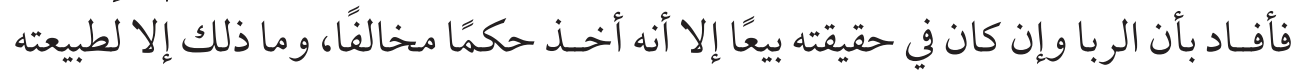

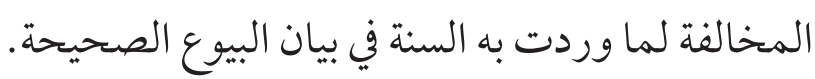

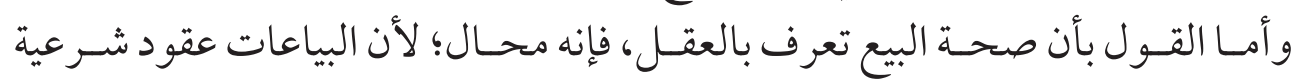

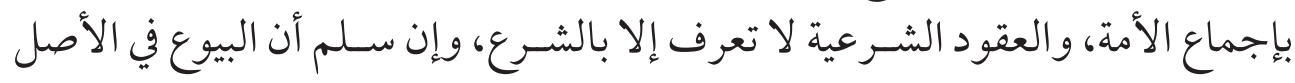

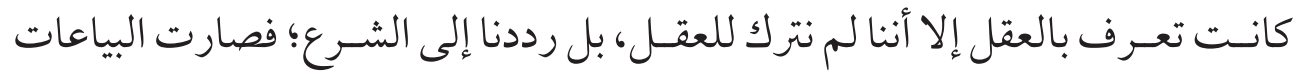

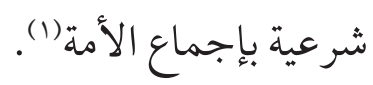

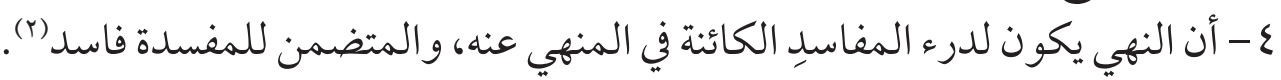

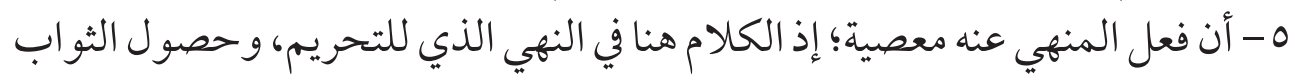

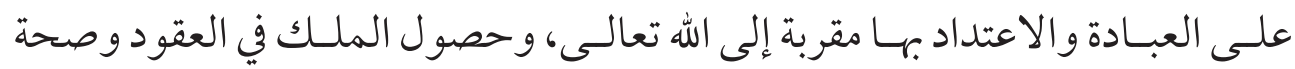

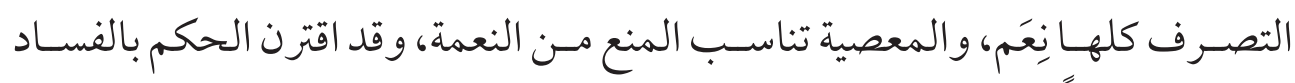

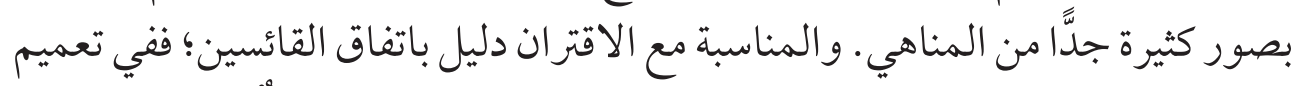

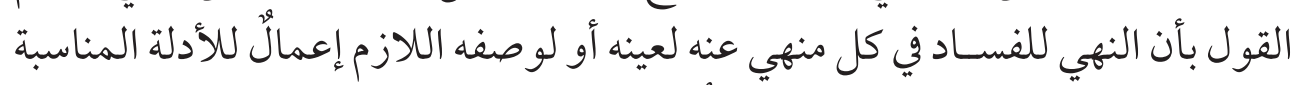

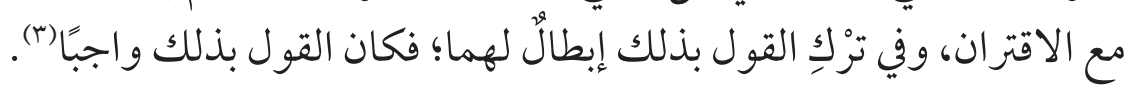

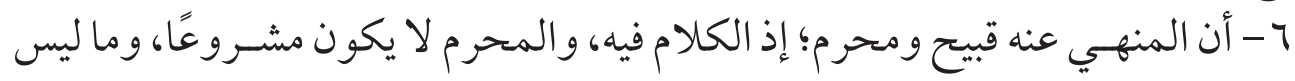

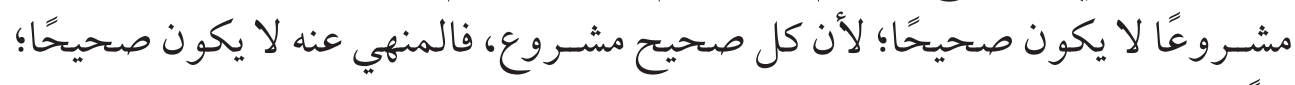

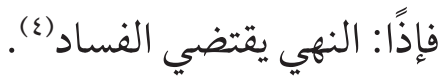

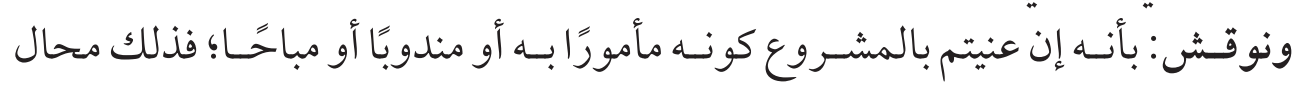

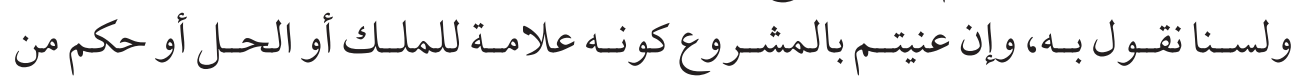

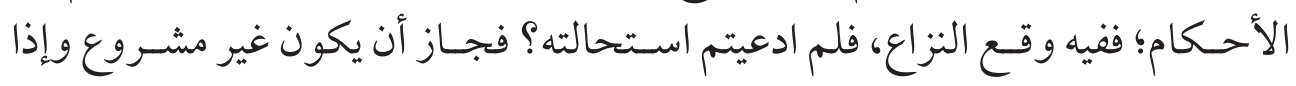

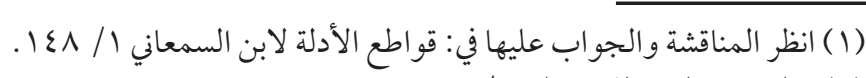

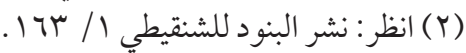

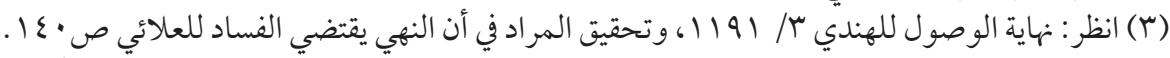

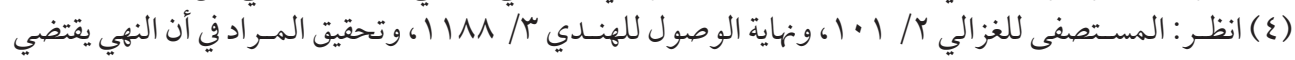


وقـع تترتب عليه الأحكام كمـا تترتب على الصحيح، كما قد فـــل في الصلاة في الدار

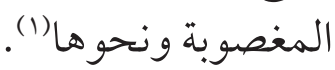

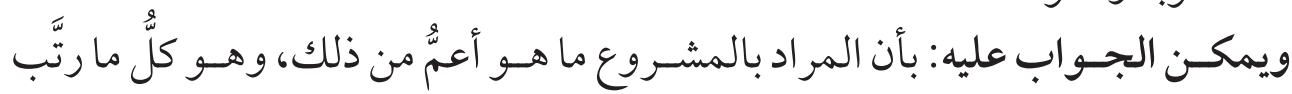

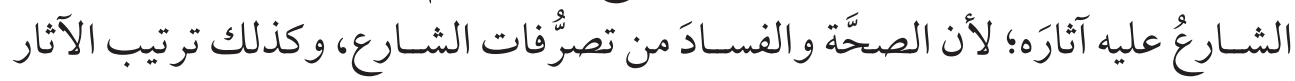
على الفعل، و المنهي عنه ليس بمشروع، فلا يترتب عليه أثروه (r).

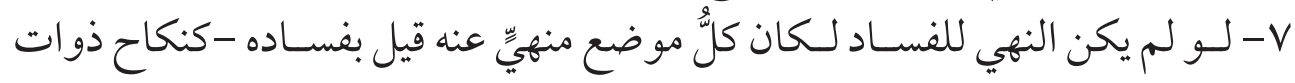

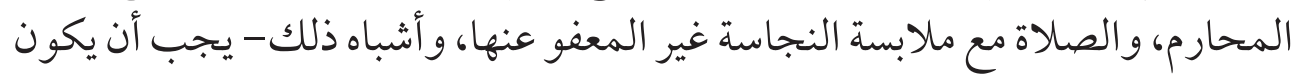

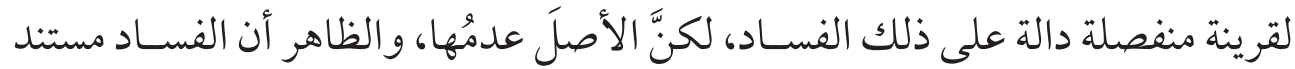
إلى مجرد النهي، وإلا كانت القرينة تذكر ولو في بعض الصور، فو جنب الفي أن يكون النهي يقتضي الفساد لذلك (r) .

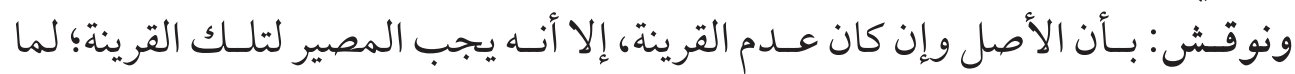
سيعلم من الأدلة الدالة على أن النهي لا يقتضي الفساد.

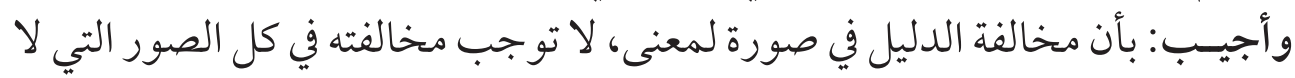

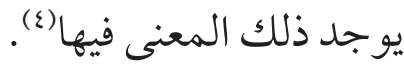
^- أن النهي ضد الأمر ونقيضه، والأمر يدلّ على إلجز اء المأمور به، ويدل على الصحة

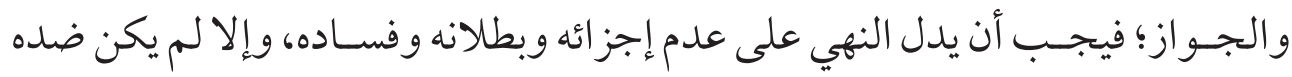
ولا نقيضه (0) وربمـا كان لقائـل أن يقول: إن الأمــــ إذا دلَّ على إجز اء المأمور بـه، فيجب أن لأ يدل

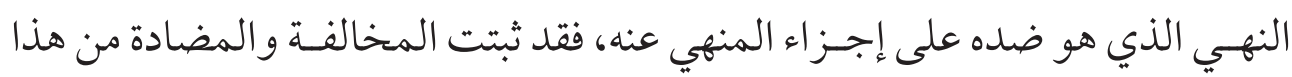

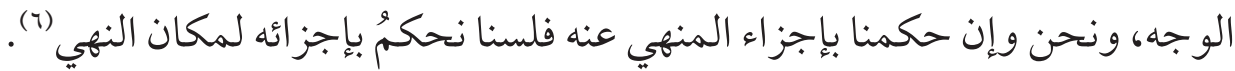

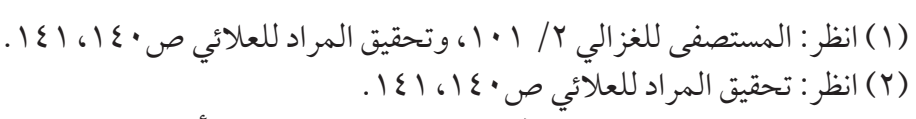

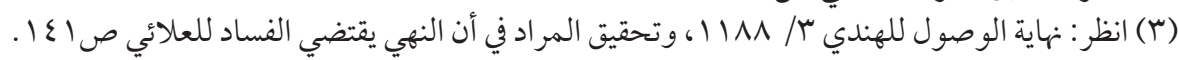

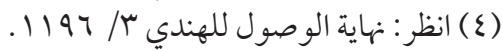

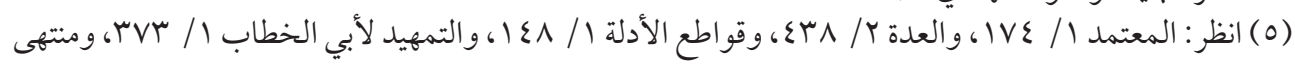

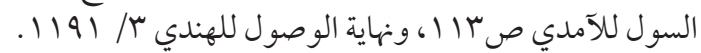

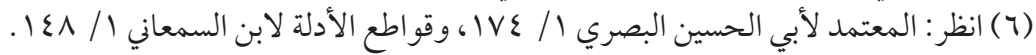

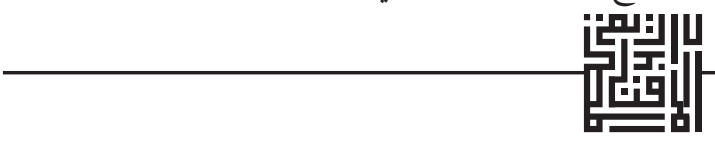


9 - أن المنهـي عنـهـ لـــ كان مجزئًا لكان طريق إجز ائه الشـرع: إما أمسر، أو إيجاب، أو

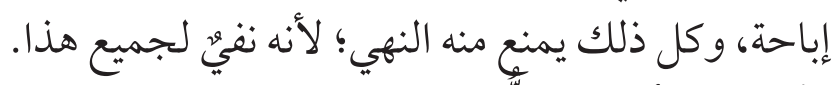

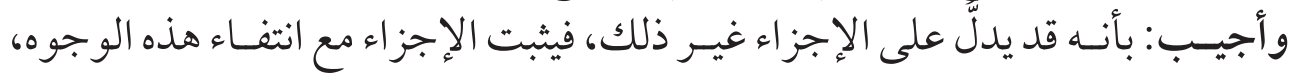

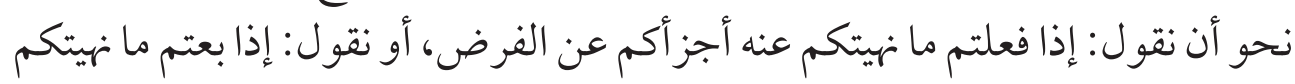

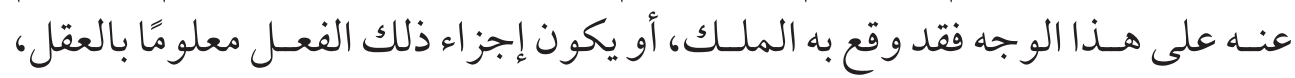
وذلك كله لا يمنع منه النهي (1).

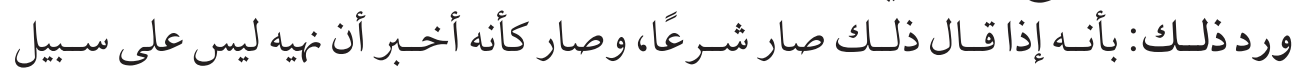

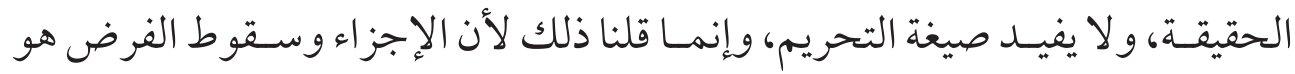

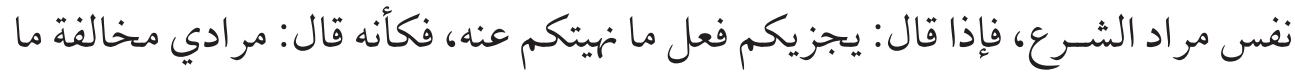
أنهاكم عنه، وقد تنزه عن ذلك. و أمـا الإجـز اء بالعقل : فالعقل لا يدل على الإجز اء، و لا على البطلان بشـيء من فروع

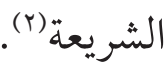

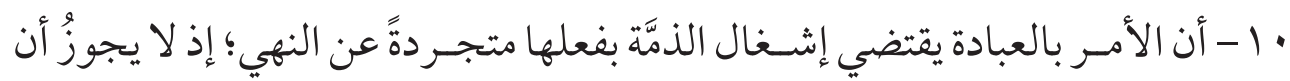

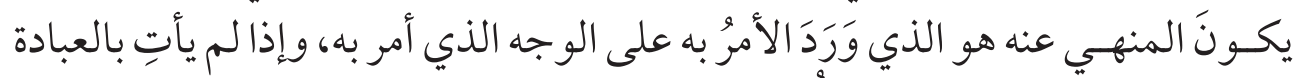

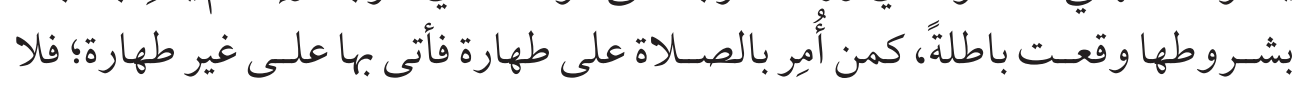

$$
\text { تصحُ وتبقى في ذمَّته (r). }
$$

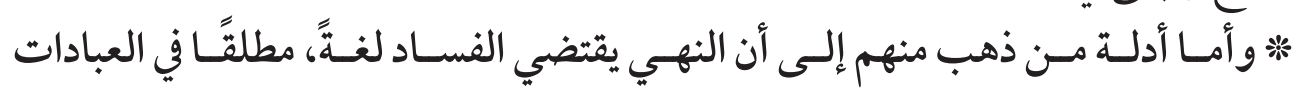

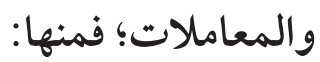

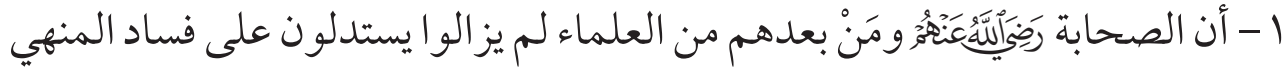

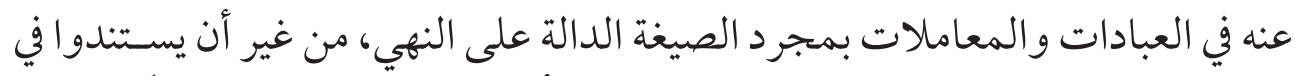

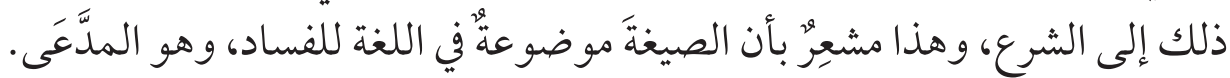

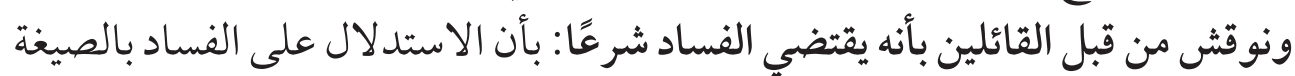

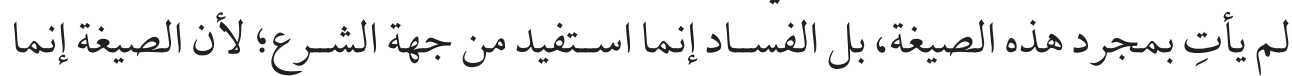

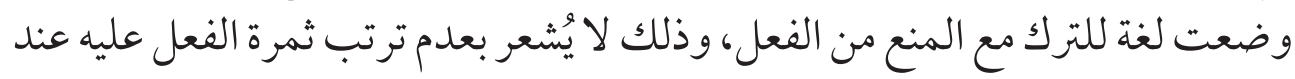

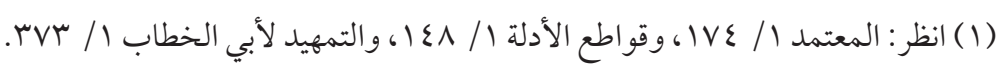

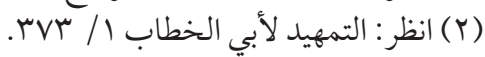

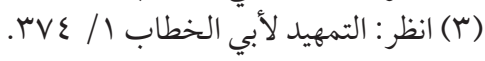


المخالفة، إنما الذي يدلّ على ذلك هو الشَـرع؛ فتكون الصيغة دالةً على الفسـاد شرعًا لا لغةًّ، فيبطل ما تدعونه (1) فإن قيل: بأنه يلزم عليه أن يكون الشارع قد نقل النهي عن موضوعه في اللغة، والأصل

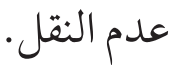
أجيب: بأن ذلك إنما يلزم إذا كان الفسـاد مسـتفادًا من لفظ النهي بطريق المطابقة، أما

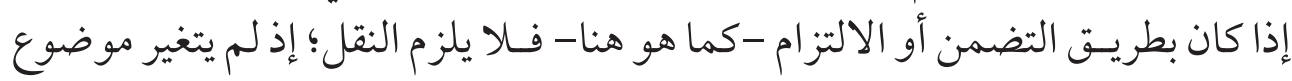

اللفظ (r) إنال

ويمكن أن يجاب بأنه: قد دار الأمر في استـدلال الصحابة والعلماء بعدهم على الفساد

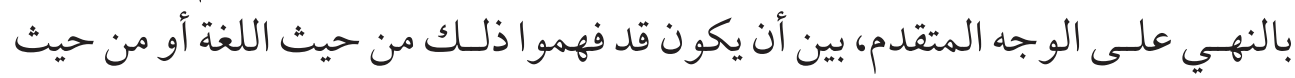

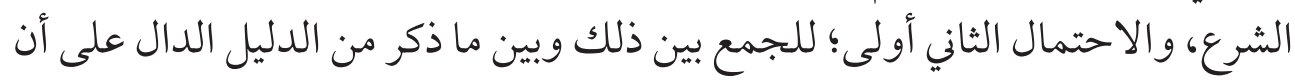
ذلك ليس من موضوع اللفظ (r).

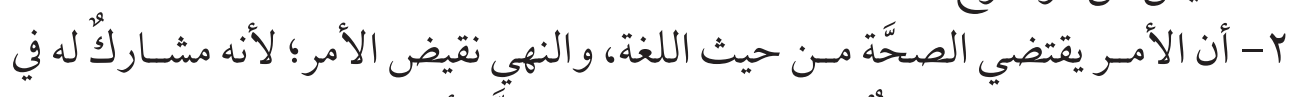

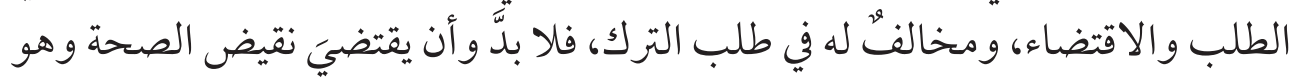

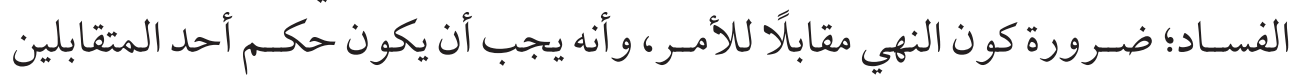

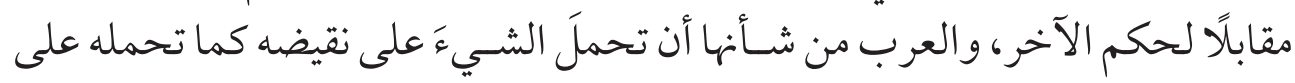

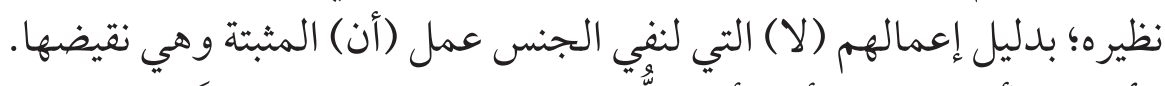

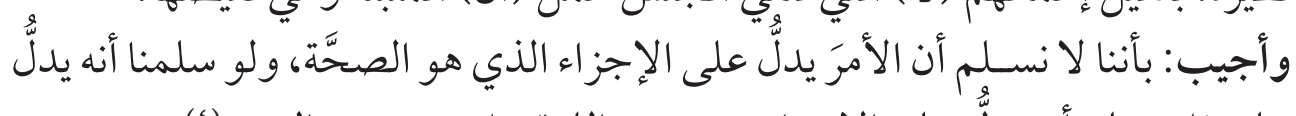

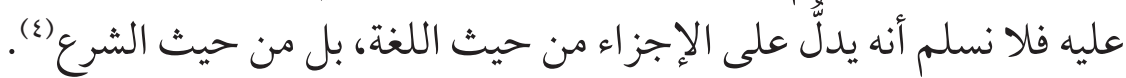

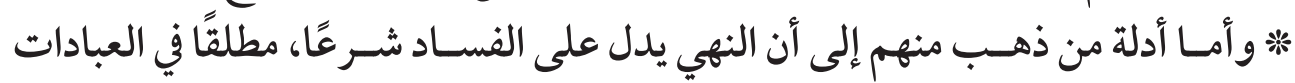

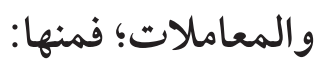

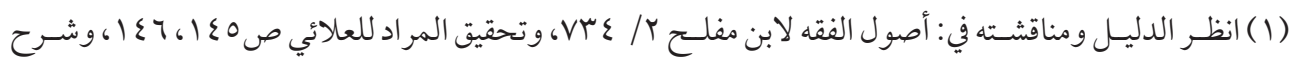

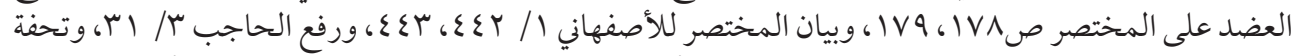

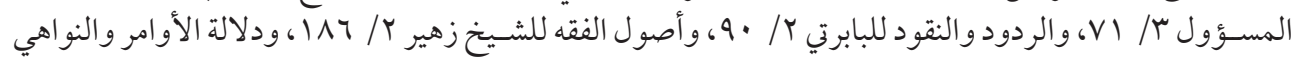

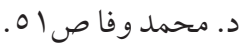

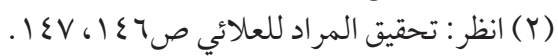

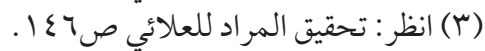

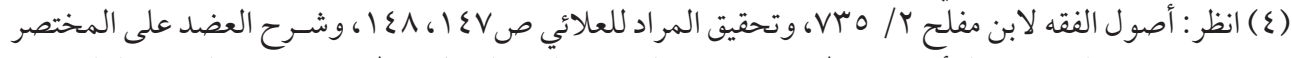

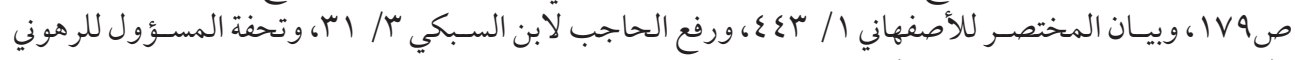

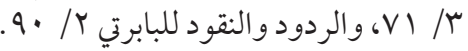


1 - أن العلماء لم يز الو ا يستدلون على فساد المنهي عنه بصيغة النهي، وبما أن الصيغة

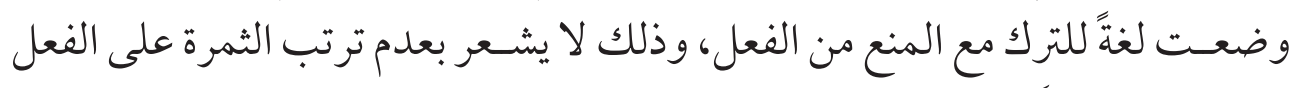

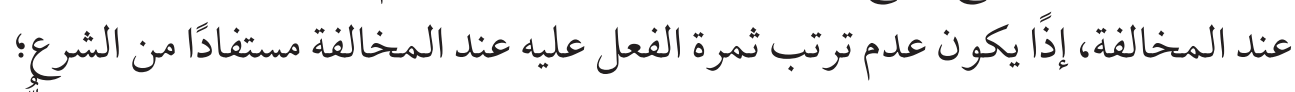

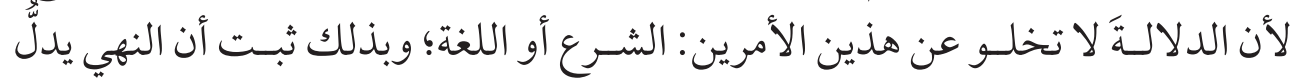

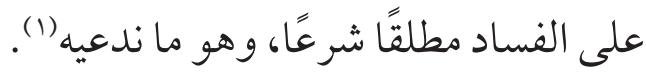

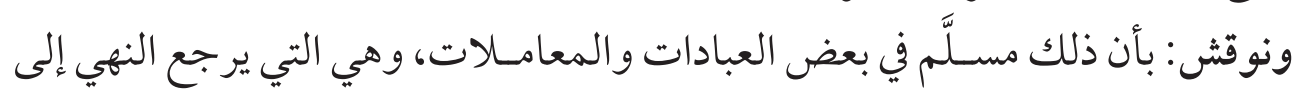

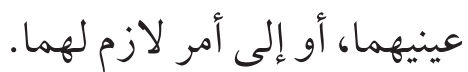

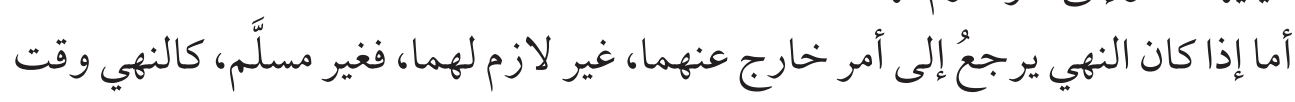
النداء، فإنه لا يقتضي الفساد (r).

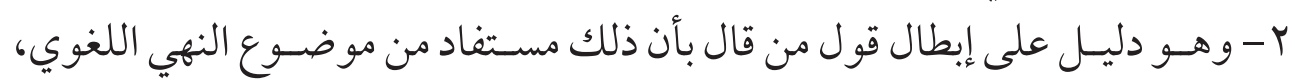

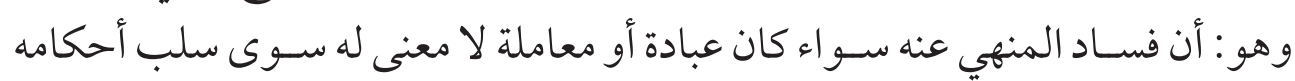

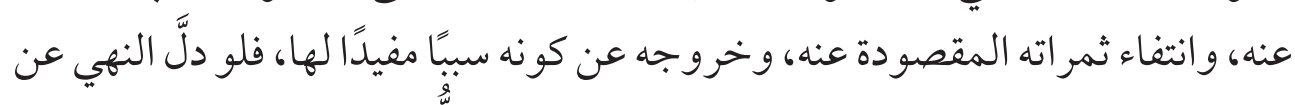

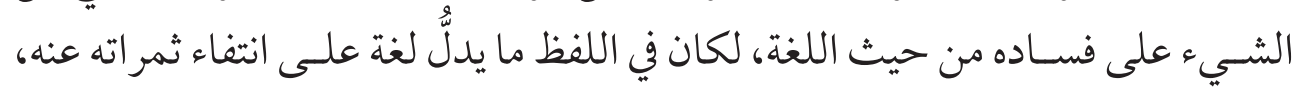
و اللازم باطل، فالملزوم كذلك.

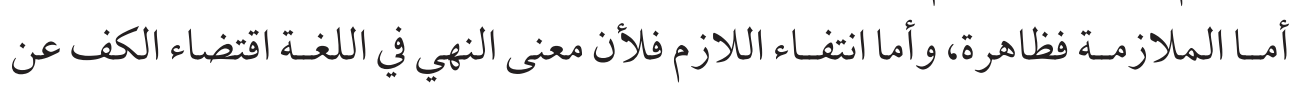

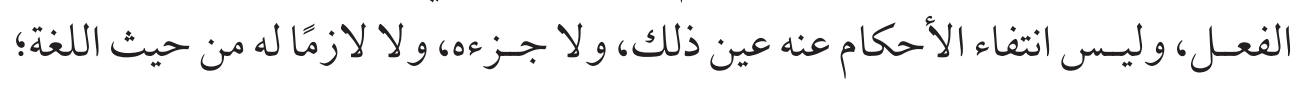

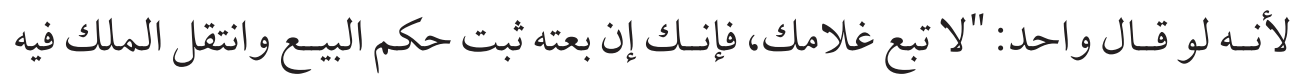

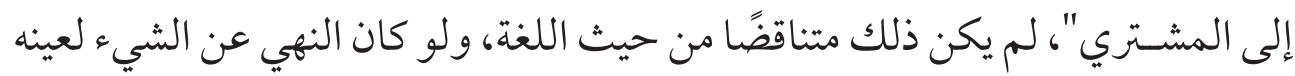
مقتضيًا لفساده من موضوع اللغة، لكان ذلك متناقضًا.

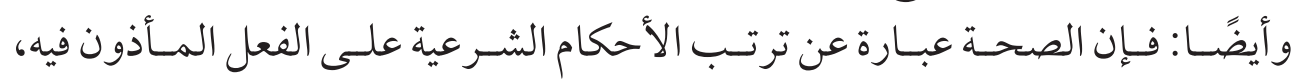

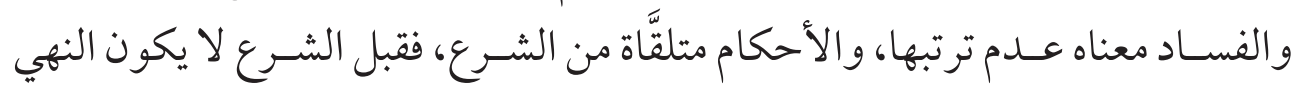

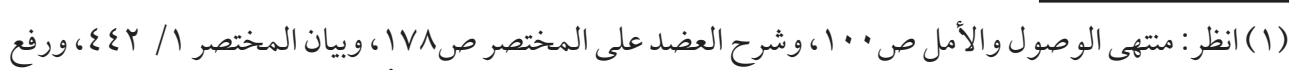

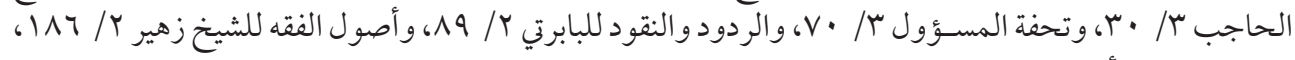

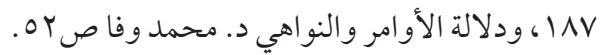

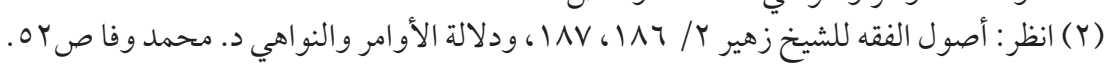


دالَّا على فساد و لا صحة، و الموضوعات اللغوية متلقاة عن العرب قبل الشرع؛ فليس

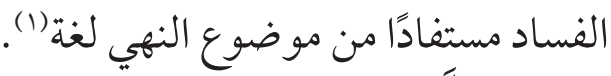

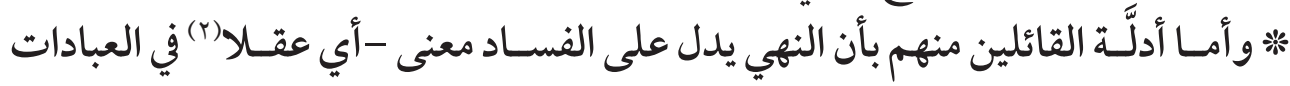

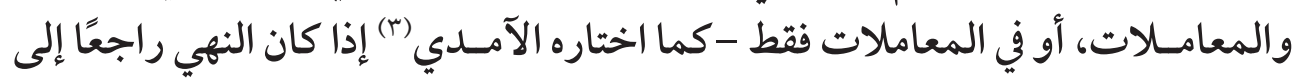
عين المنهي عنه، فمنها:

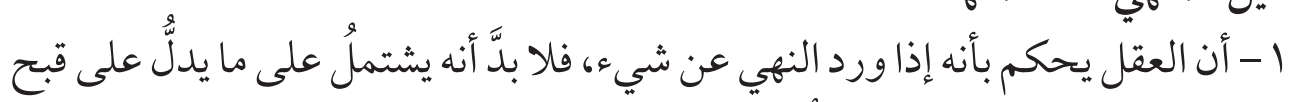

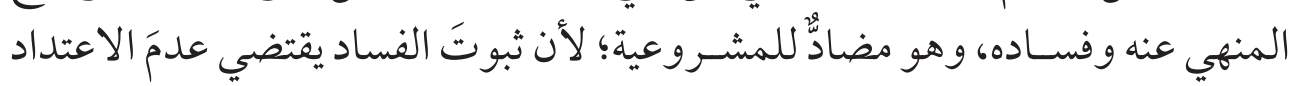

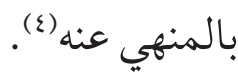

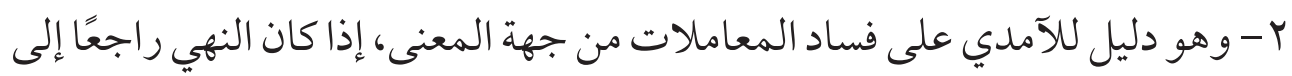

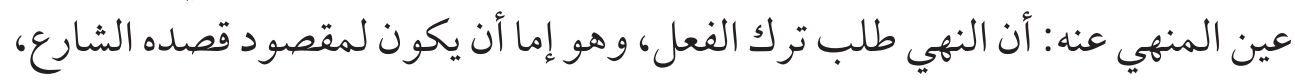

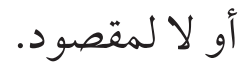

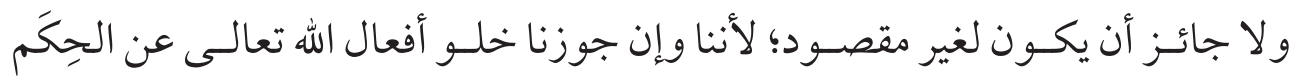

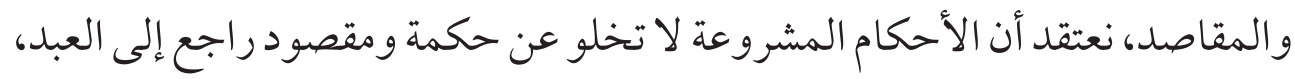
لكن لا بطريق الوجوب؛ بل بحكم الوقوع.

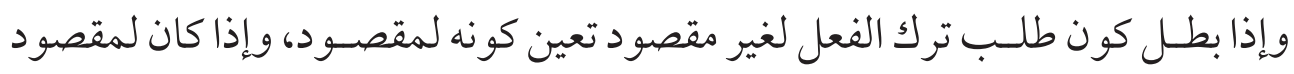

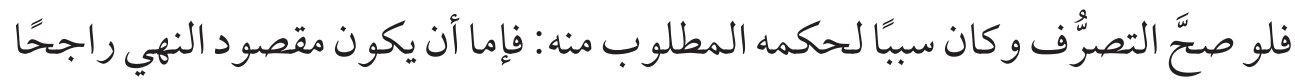
على مقصود الصحة، أو مساويًا، أو مرجوحًا.

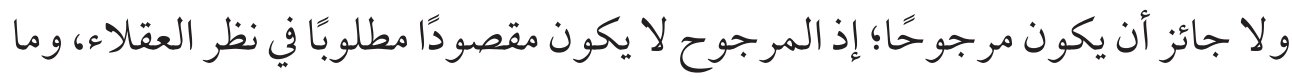

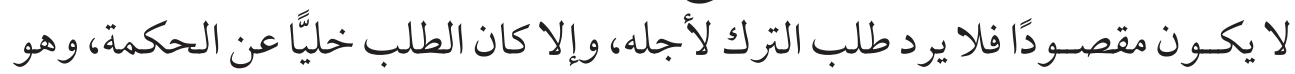

•متنم

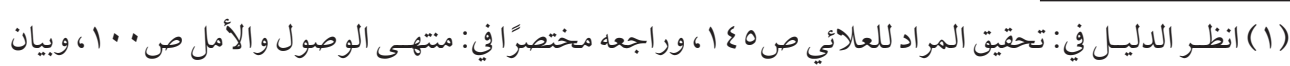

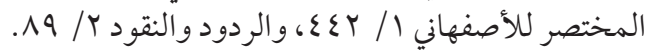

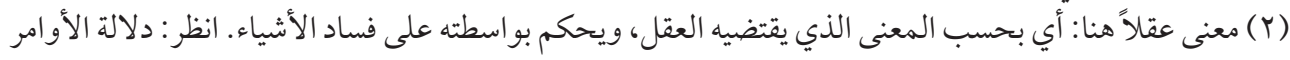

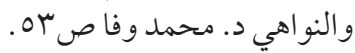

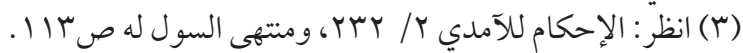

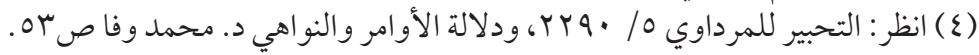




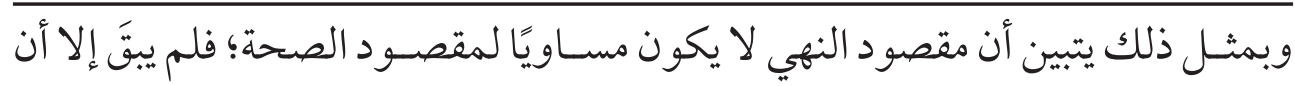

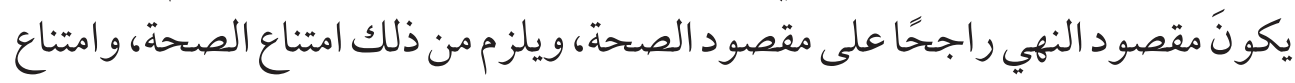

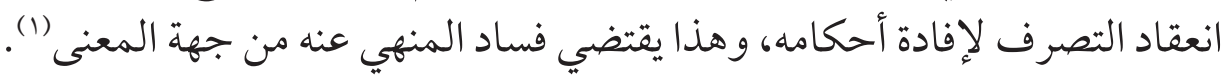

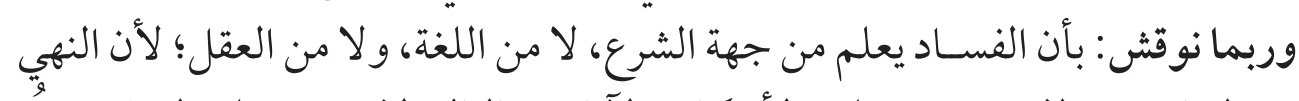

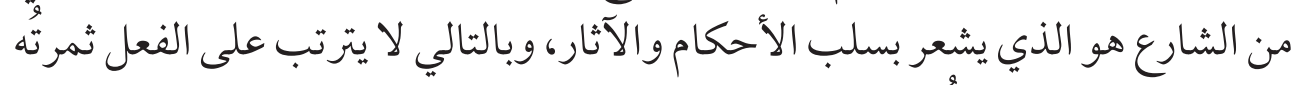

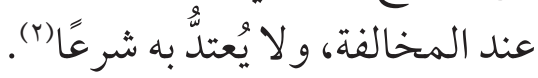

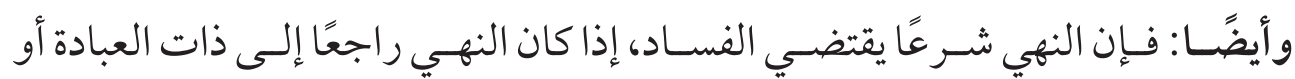

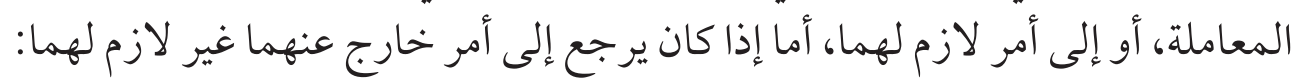
فلا يقتضي الفساد (r).

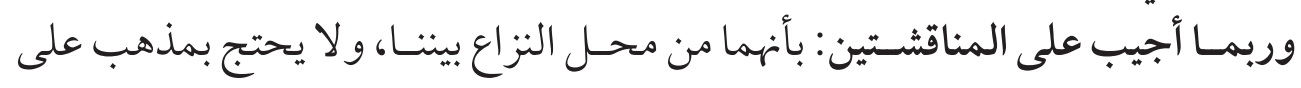
مذهب.

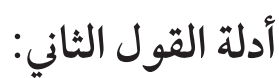

استدلَّ القائلون بأن النهي لا يقتض النّي فساد المنهي عنه مطلقًا، بعدة أدلة، منها:

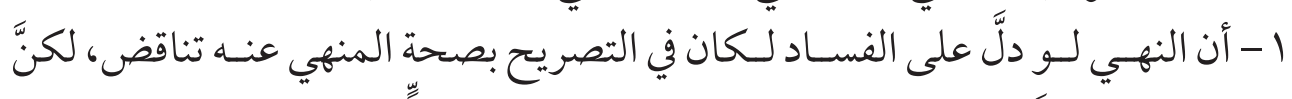

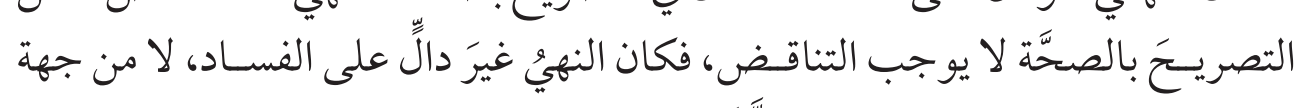

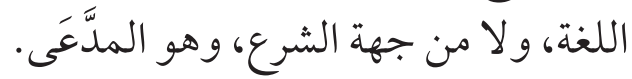

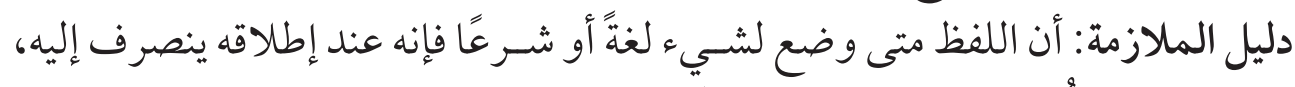

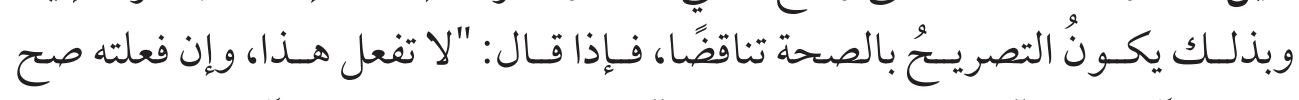

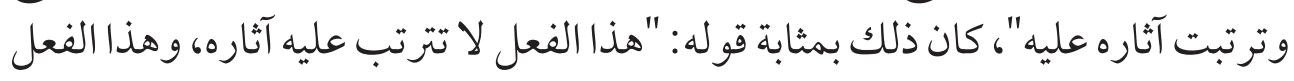

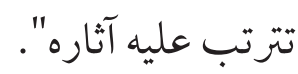
دليل الاستثنائية: أن من قال: "لا تفعل هذا، و وإن فعلته ترتبت عليه آثاره" لا تناقض فيه،

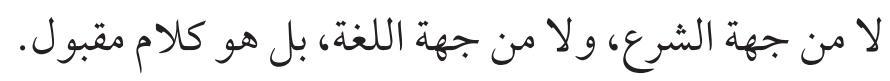

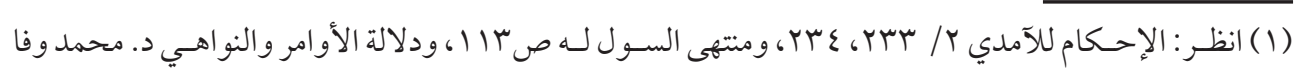

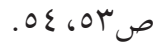

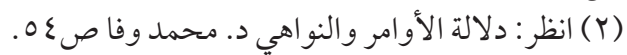

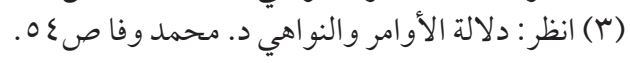


ونوقش: بأن النهي ظاهر في الفسـاد، وليس نصَّا فيه، ومتى كان النهي ظاهرًا في الفسـاد

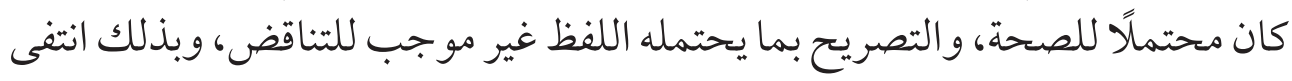

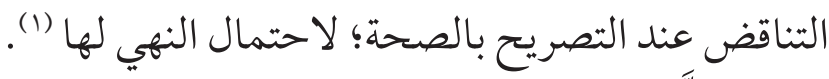

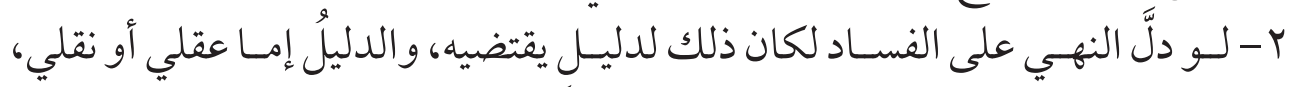

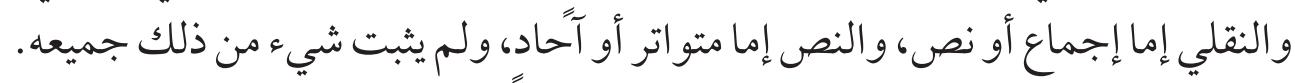

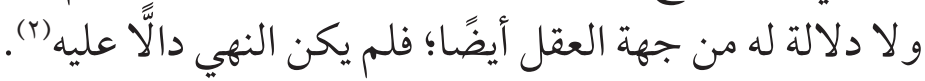

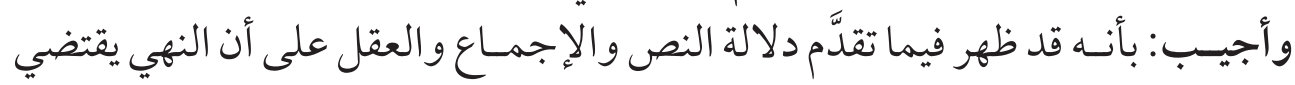

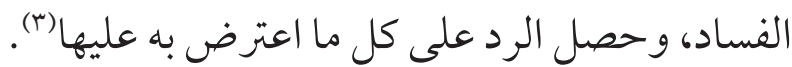

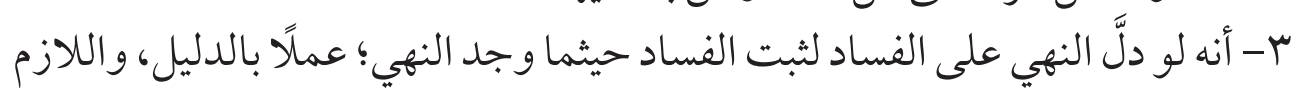

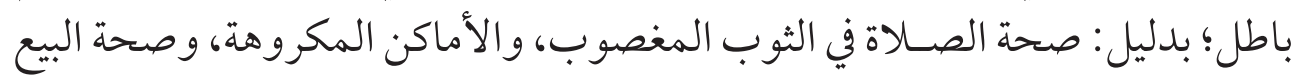

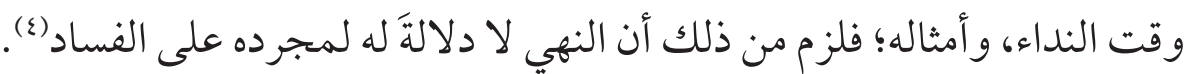

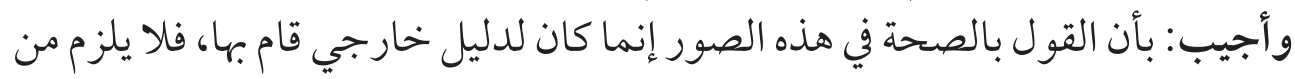

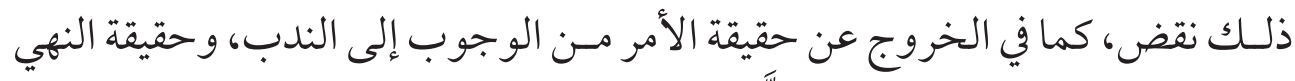

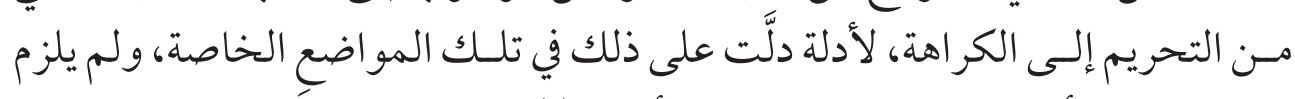

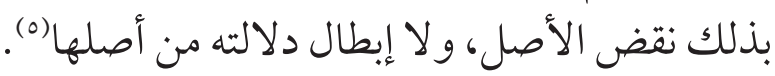

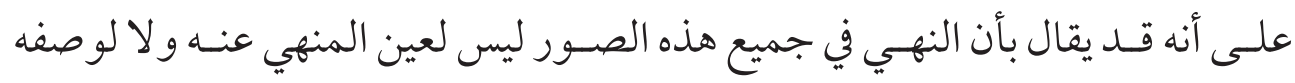

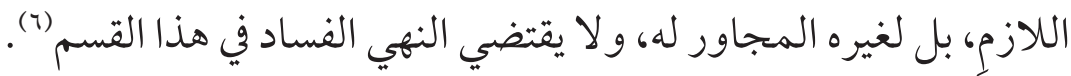

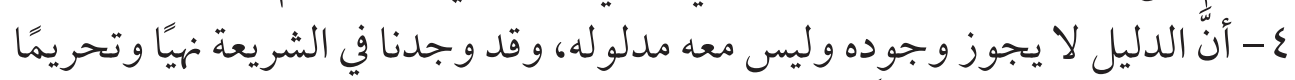

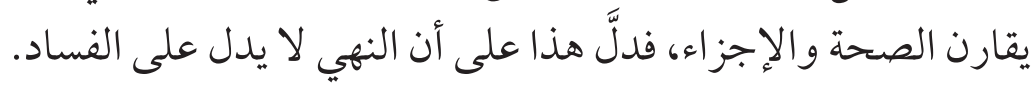

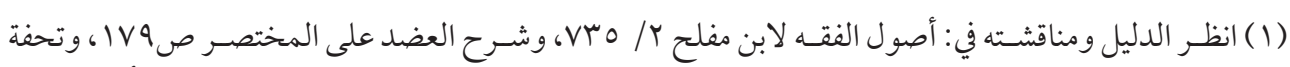

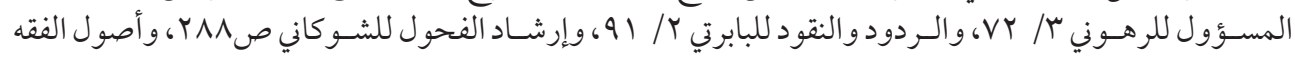

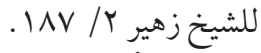

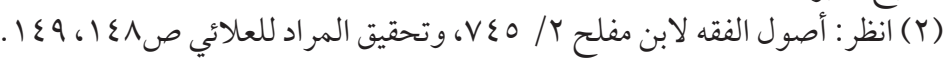

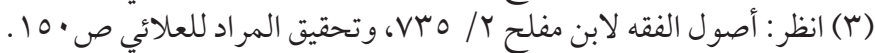

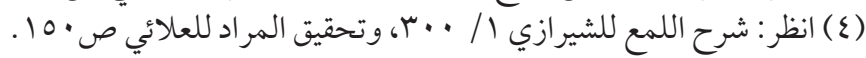

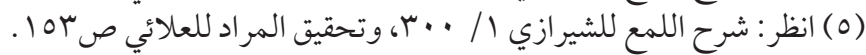

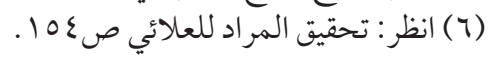




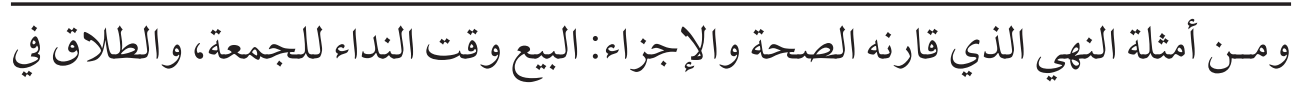

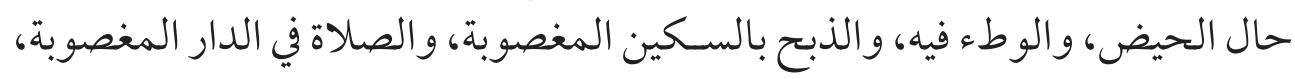

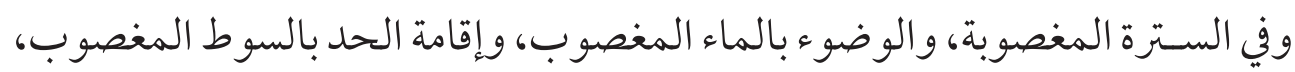
و أشباه ذلك؛ فإنه يقع موقع الجائز، مع كونه محرمًا منهيَّا عنه (1).

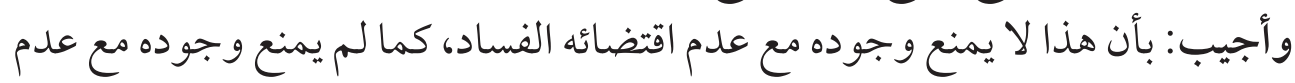
اقتضائـه التحريم، وقد ثبت أن إطلاق النهي يقتضسي التحريم، و إن دل الدليل على أنه أنه لا يوجب الفساد(r). فإن قيل: إن دلَّ الدليلّ على أنه لا يوجبُ التحريم؛ خرج من أن أن يكون نهيًا. أجيب: بأنه

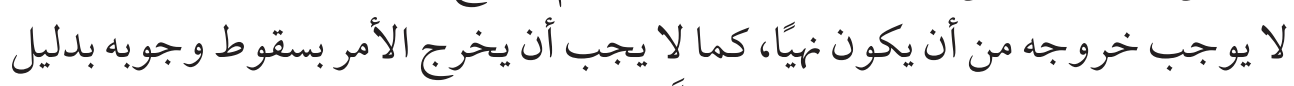

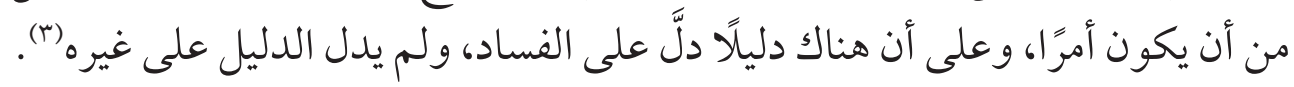

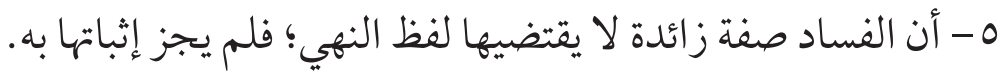

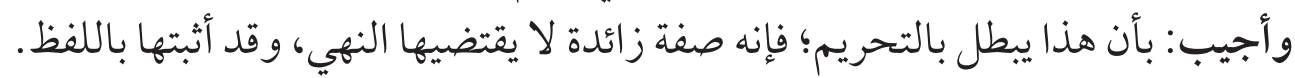

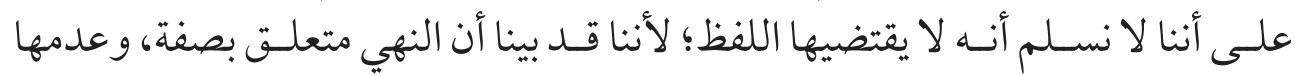

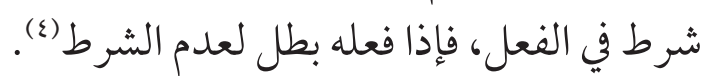

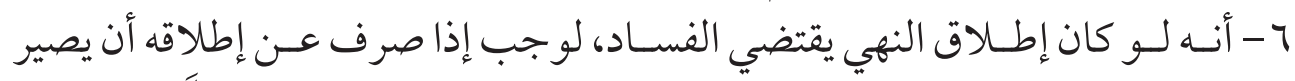

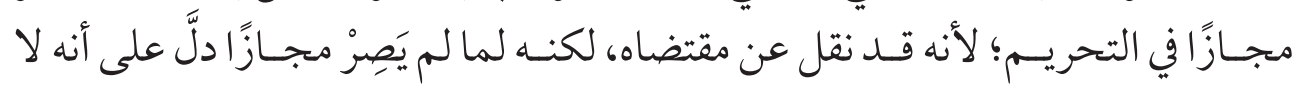
يقتضي الفساد.

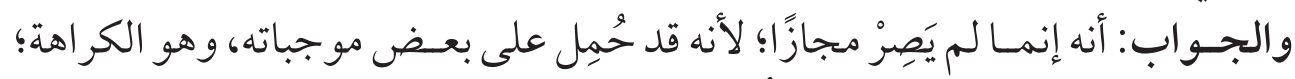

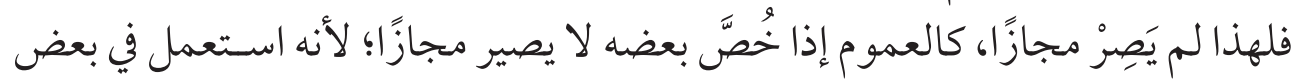

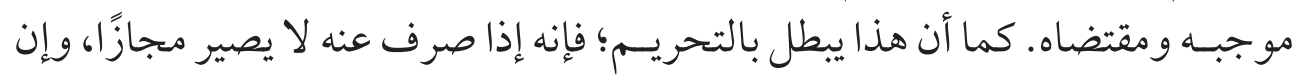
كان الإطلاق يقتضيه (0)

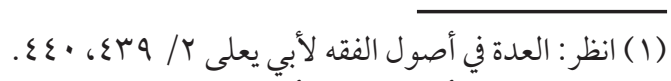

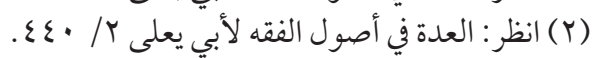

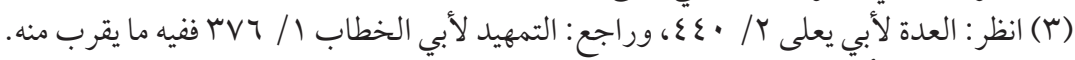

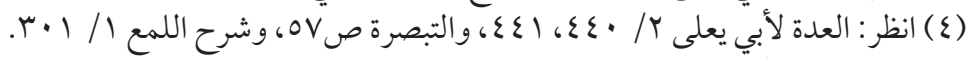

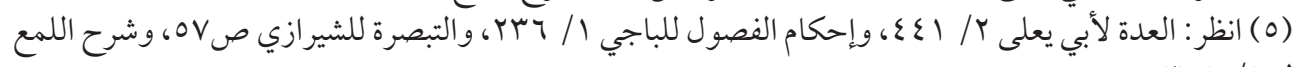


V- أن النهي إما أن يدلَّ على الفساد دلالةً لفظيةً أو معنويةً، وهما باطلتان؛ فالقول بأنه يقتضي الفساد باطلٌ.

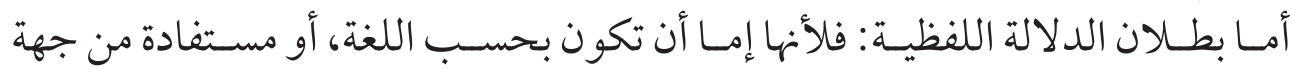

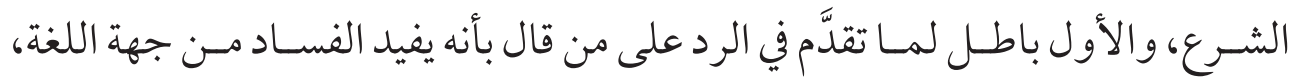

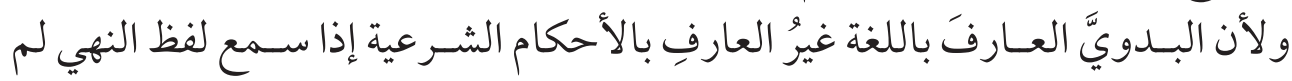

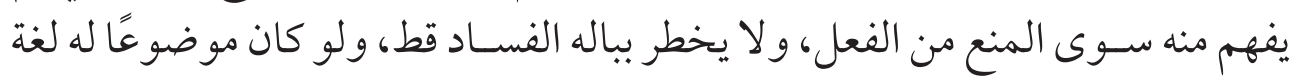
لم يكن كذلك.

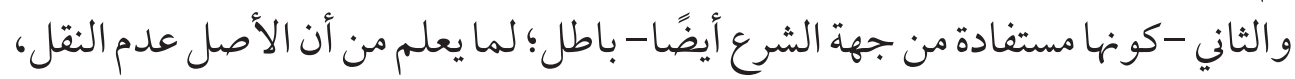

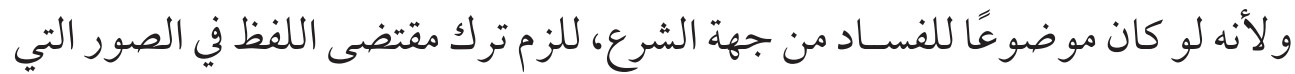

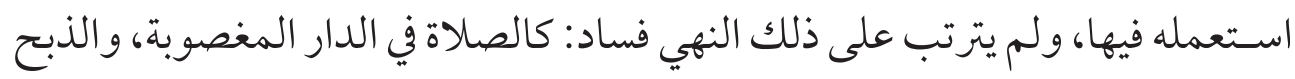
بسكين مغصوبة، ونحو ذلك، وهذا بخلاف ما إذا لم نقل بأنه يدل على الفساد، فإنه في

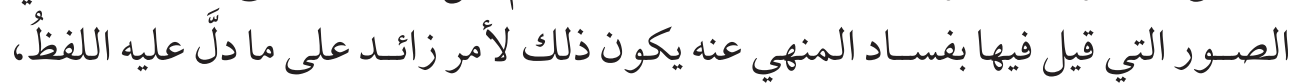

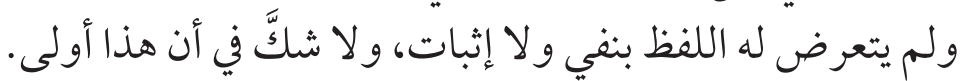

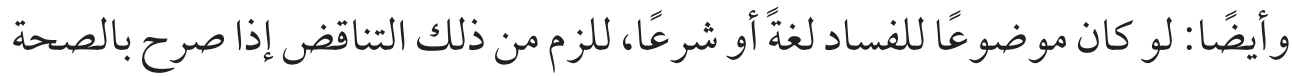

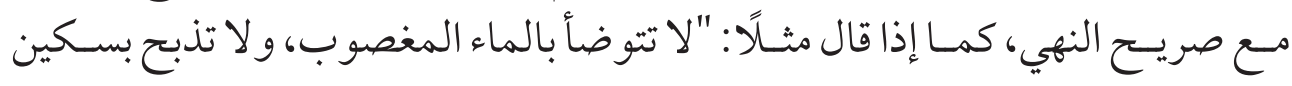

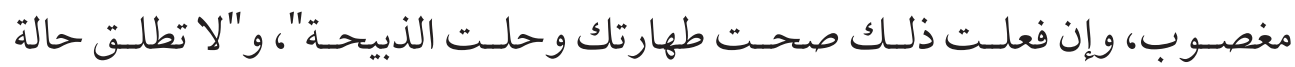
الحيض فإن فعلت نفذ طلاقك"، إلى غير ذلك من الصور التي لا اسـتبعاد في صحتها،

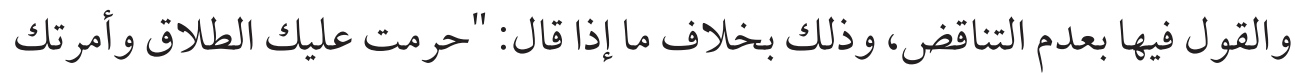

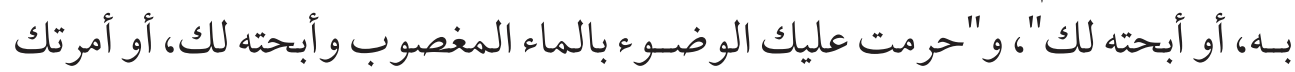
به"، فإن ذلك متناقض غير معقول. أبحته لوك

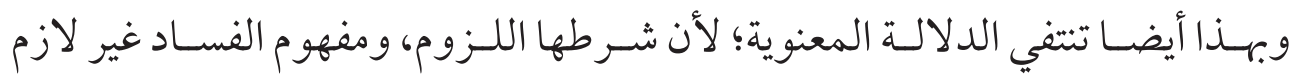

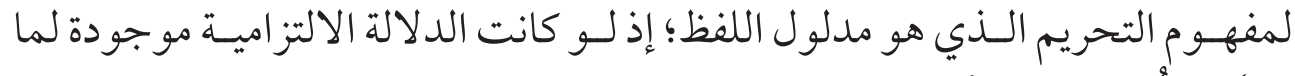

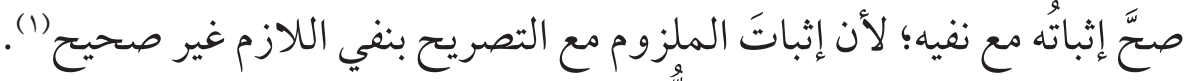

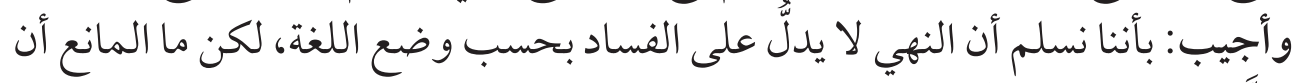

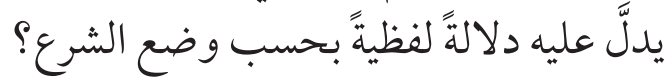

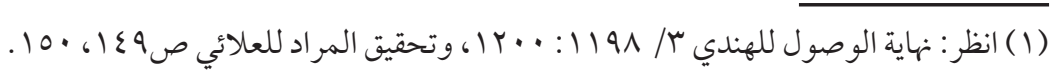

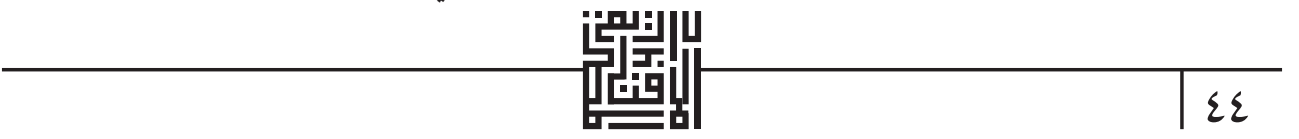


و أمـا قولكم: بأنـه "يلزم منه النقل و الأصل خلافه"، فيجاب عليـه: بأنه إنما يلزم النقل

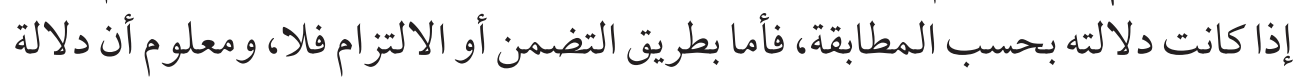
النهي على الفساد بحسب اللزوم.

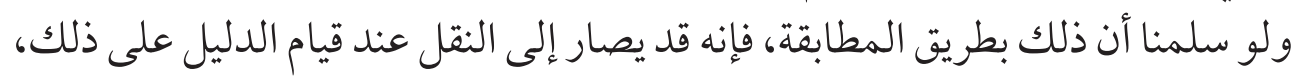

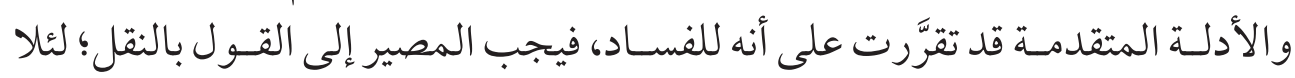

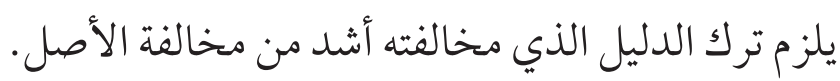

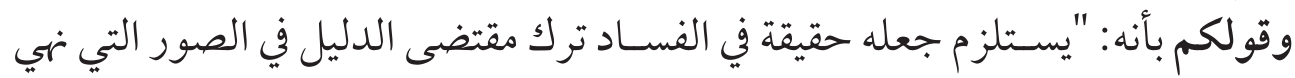

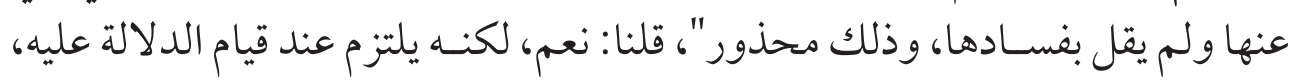

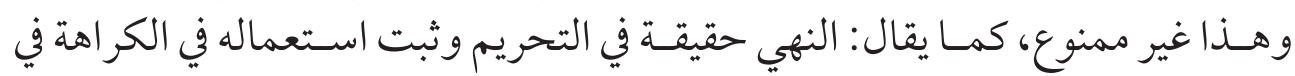
صور كثيرة عند قيام دليل على ذلك.

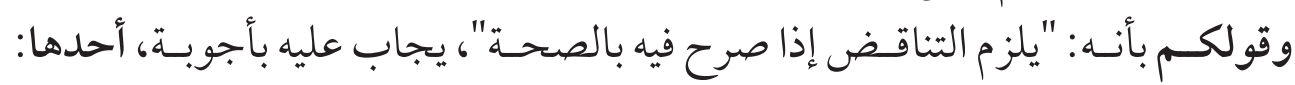

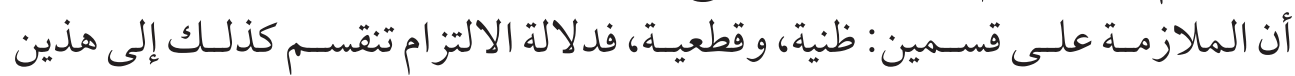

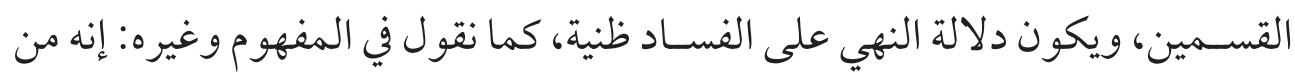

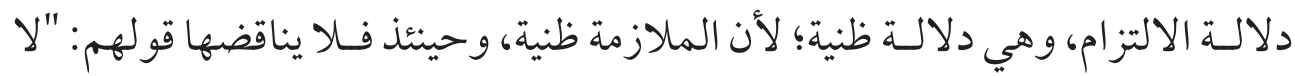

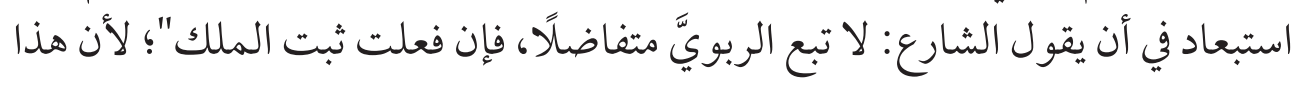

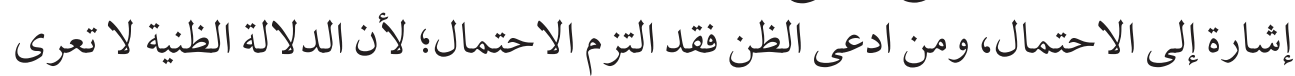

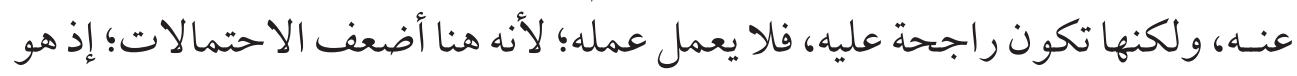

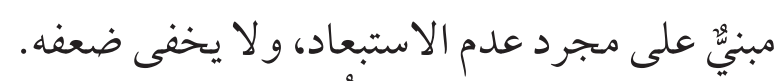

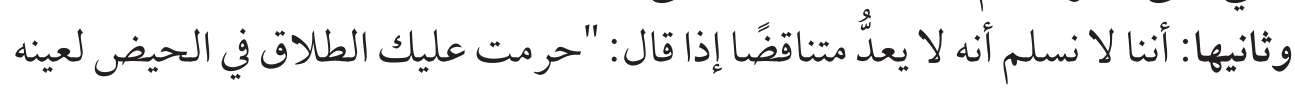

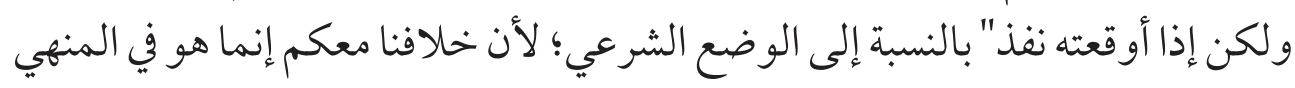

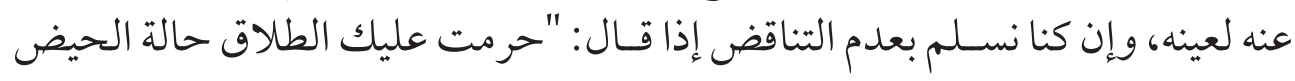
وإذا أوقعته نفذ"؛ لاحتمال أن يكون التحريم لأمر خارجي وإني وهو تطويل العدة، بخلاف

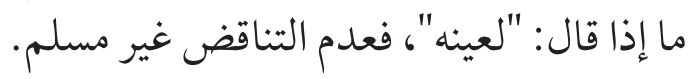

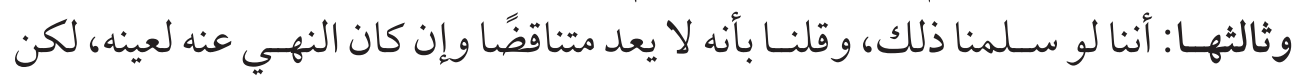

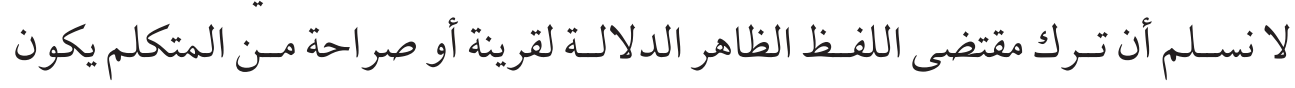


مناقضًا لكلامه؛ قياسَـا على أن اللافظ باللفظ العام وبأسـماء العدد مع التخصيص لهاء و الاستثناء منها لا يعد متناقضًا ومتهافتًا في كلامه، فكذلك الك هنا فيا.

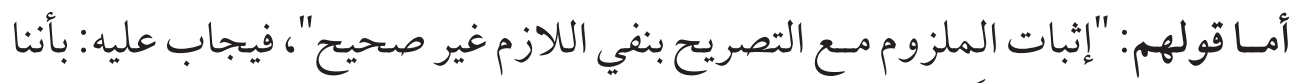

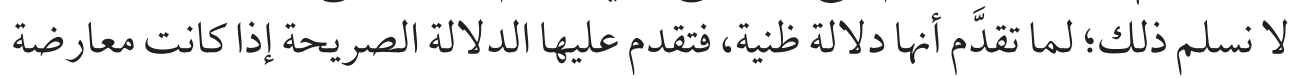

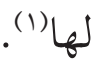

1- أن لفــ النهي لغوي، وفسـاد العبادة شـرعي، وعلى ذلك فلا يجــوز أن يكون هذا اللفظ وضع للفساد، وهو مو ضوع قبله.

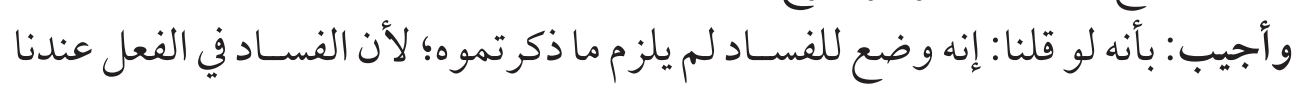
هــ انتفاء الأغر اض المقصـودة به ووجوب إعادته، وذلك أمر معقول قبل الشـرع فلا

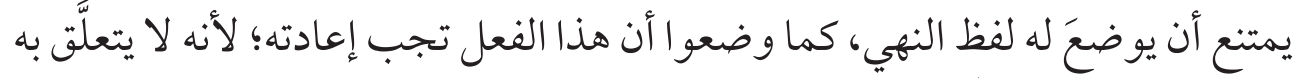

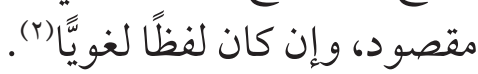
9 - أن النهي يقتضسي قبح المنهي عنه، وقبحه لا يقتضسي بطلانه، ولا يقتضي أكثر من

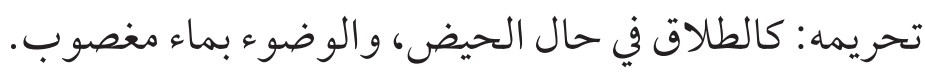

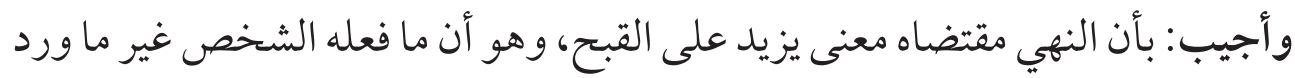

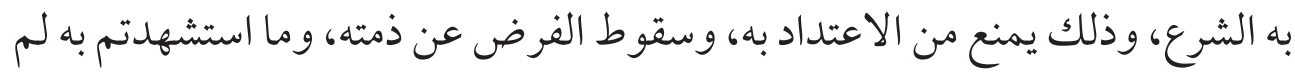

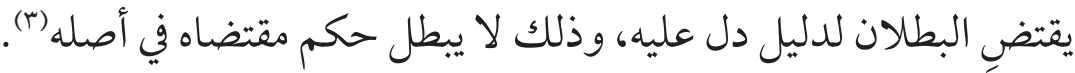

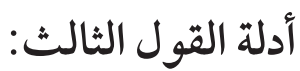

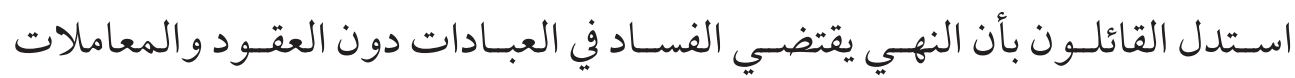
والإيقاعات، بوجوه عدة تظهر الفرق بينهما، منها:

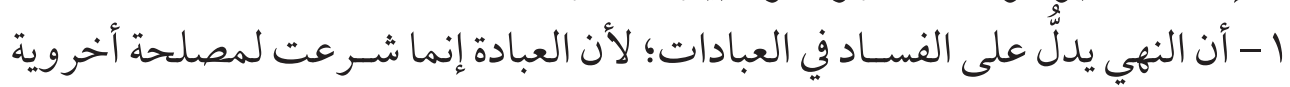

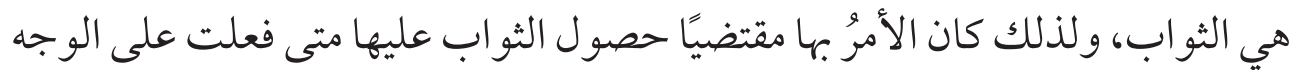

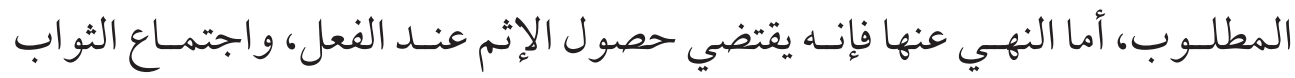

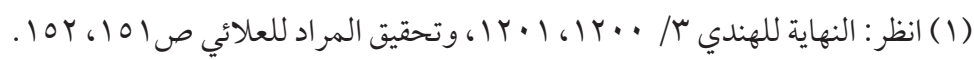

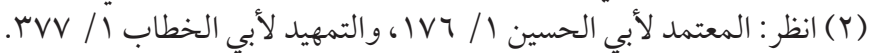

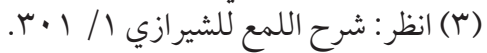


و العقاب على شيء و احد من جهة و احدة باطل؛ لما فيه من التناقض، لذلك كان النهي

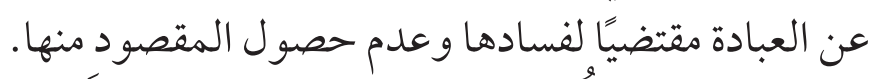

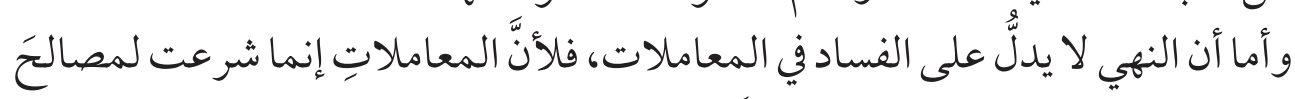

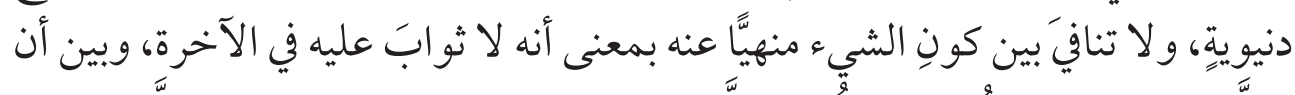

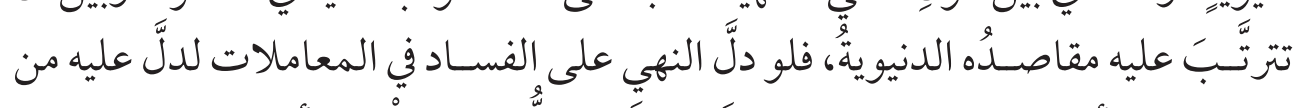

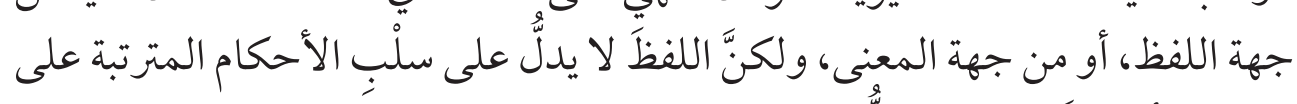

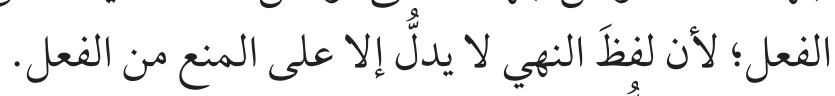

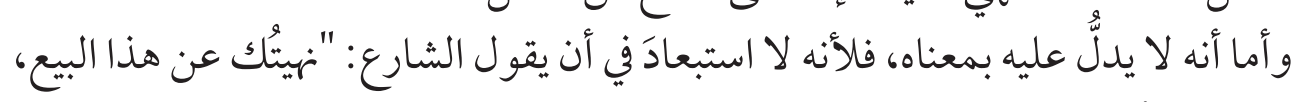

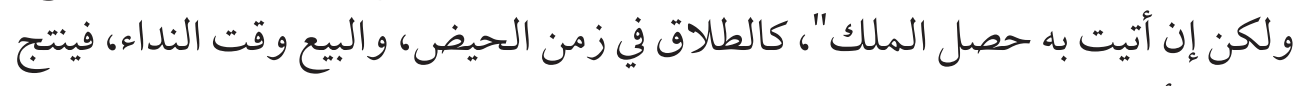

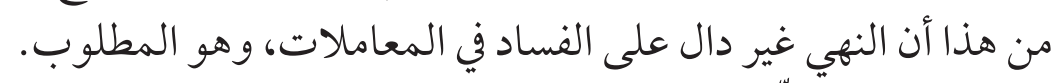

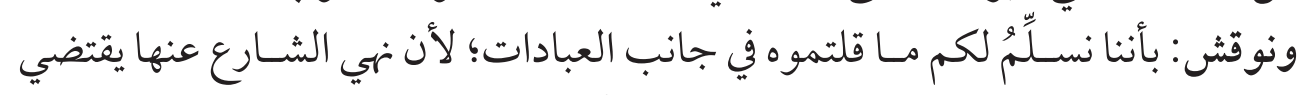

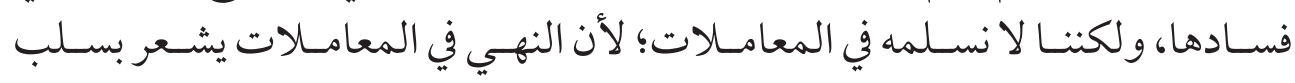

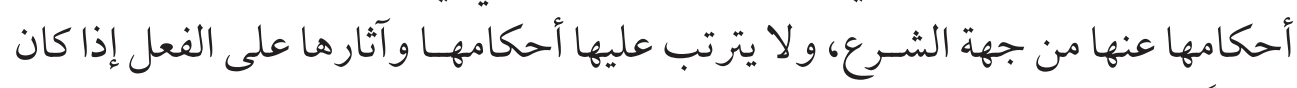
مخالفًا لنهي الشارع (1).

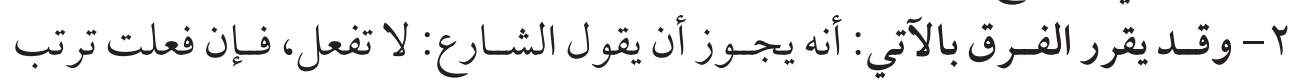

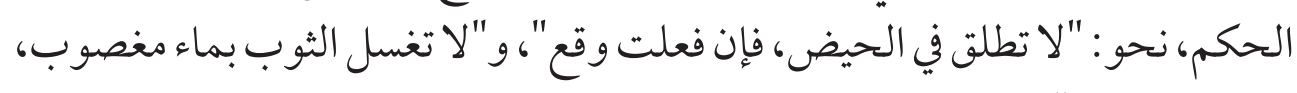

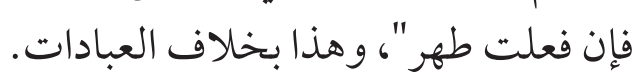
والفرق بينهما من وجهين:

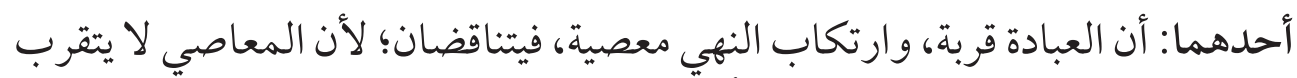

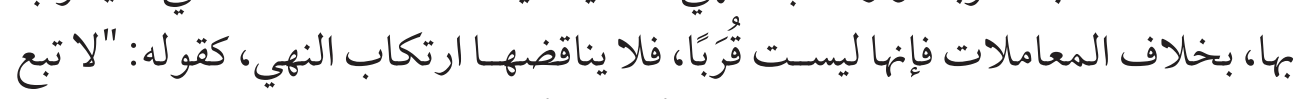

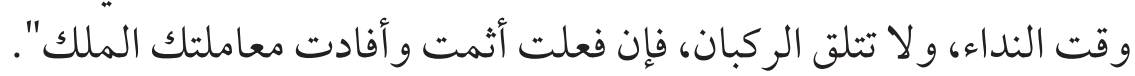

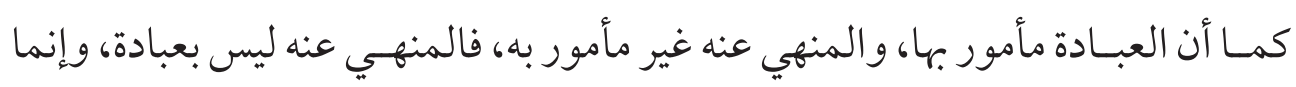

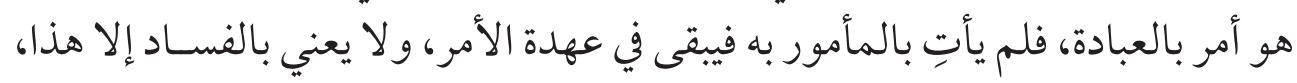

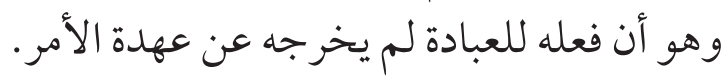

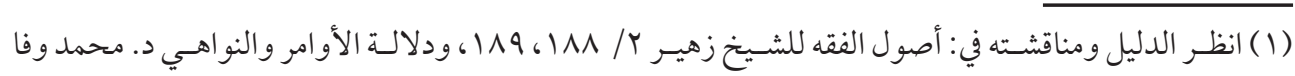
ص ص 
وثانيهمـا: أن فسـاد المعاملات بالنهي يضرّ بالناس؛ لأن فسـادَ المعاملات يفضي إلى

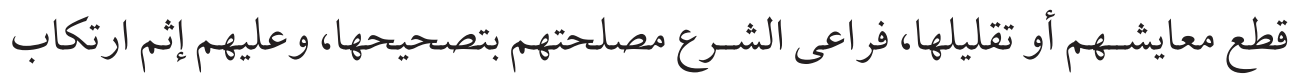
النهي، و الصحة مع الإثم لا يتنافيان.

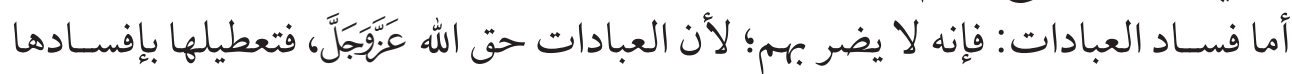

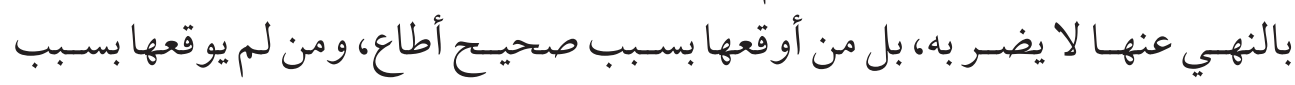

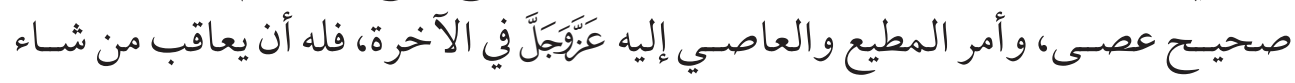

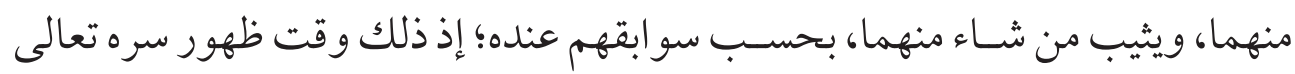

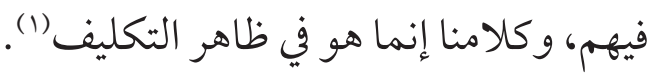

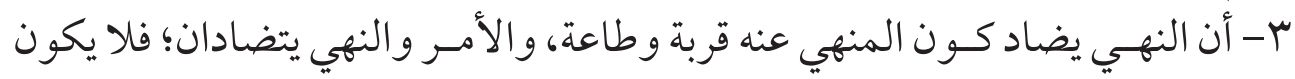

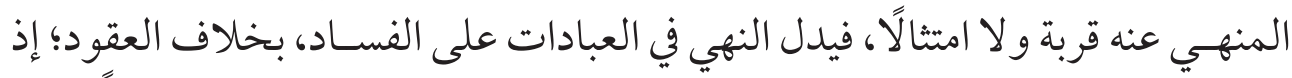

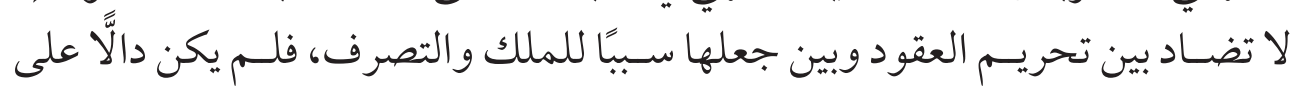
الفساد.

وحاصـل ذلك: أن النهي إنما يدل على الزجر فقط وذلك مـن خطاب التكليف، و أما

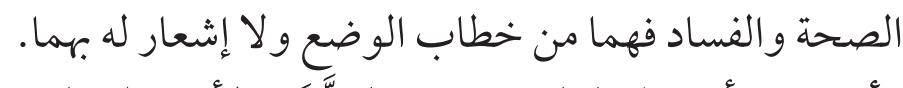

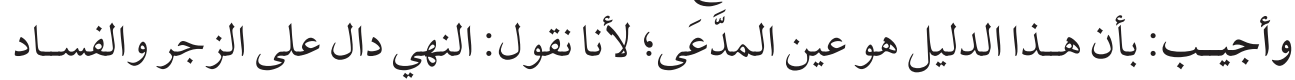

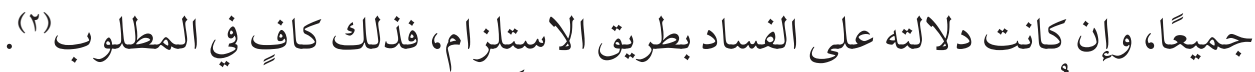

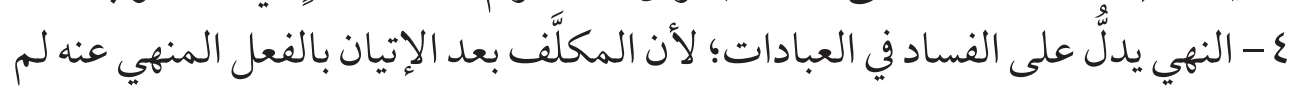
يأتِ بما أمر به، فو جب أن أن يبقى في العهدة.

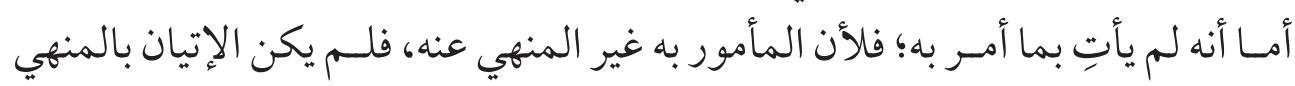

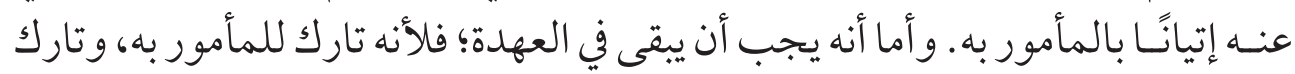

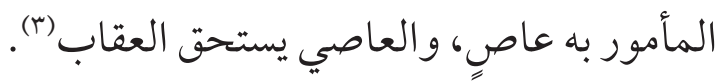

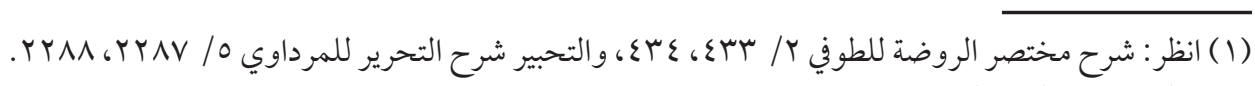

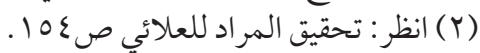

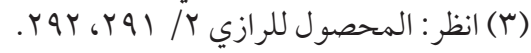




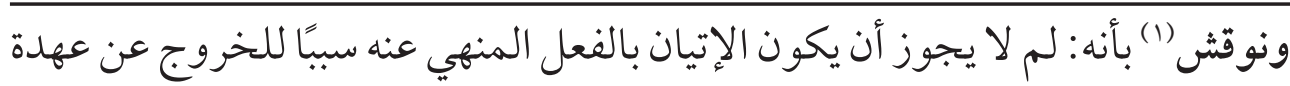

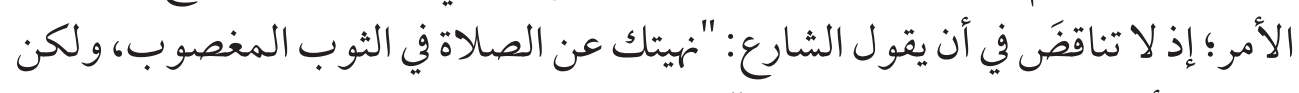

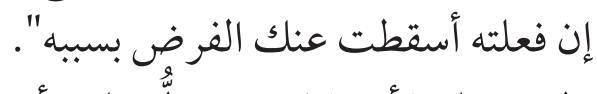

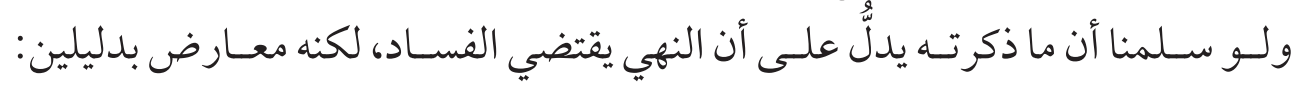

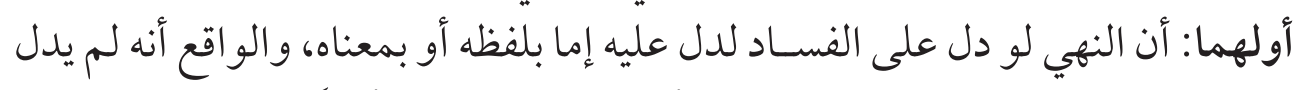

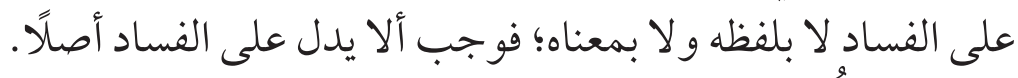

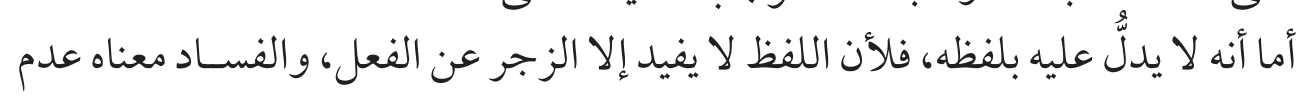
الإجزاء؛ فكان أحدهما مغايرًا للآخر.

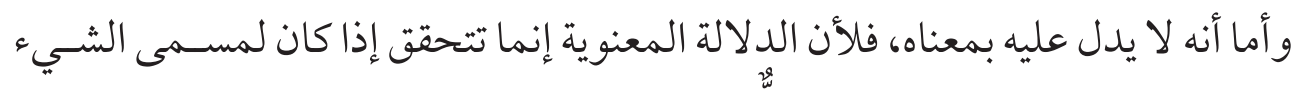

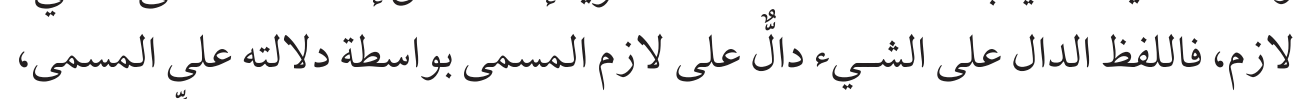

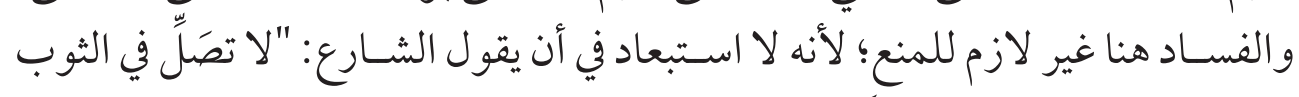

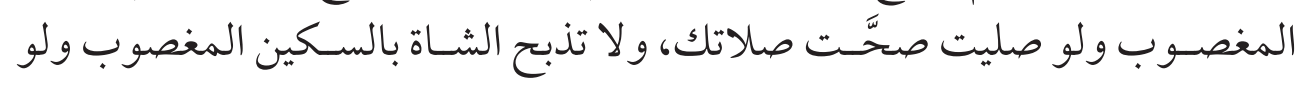

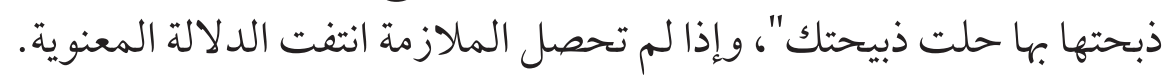

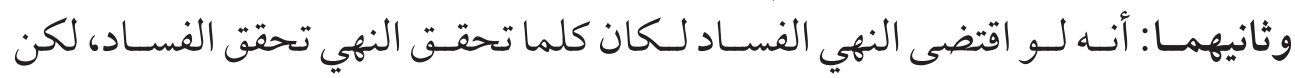

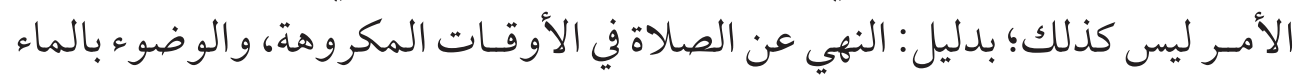
المغصوب، مع صحتهما.

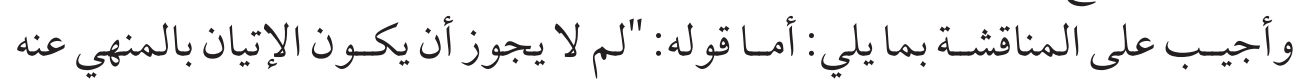

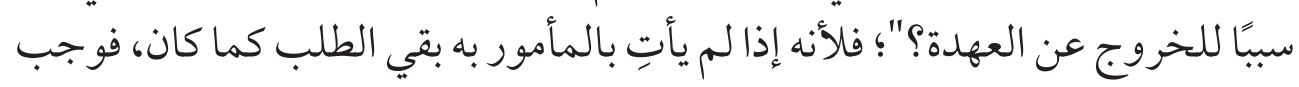

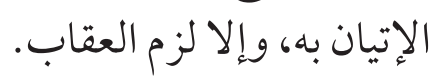

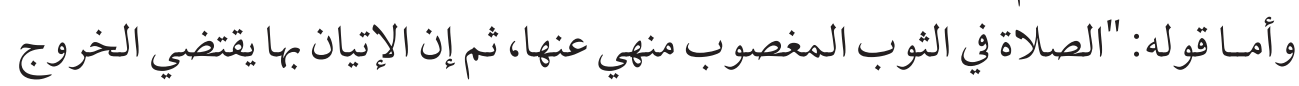

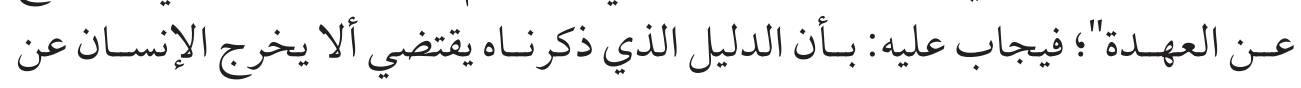

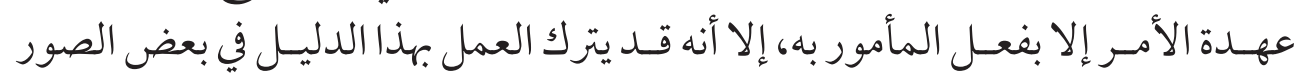

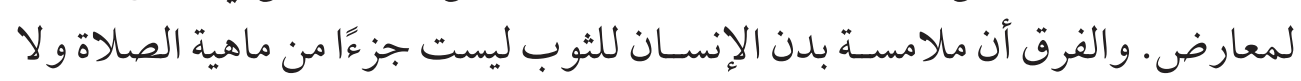

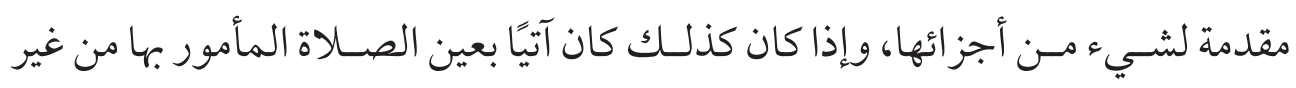


خلل في ماهيتها أصلاً، وغاية ما فيه أنه أتى مع ذلك بفعل آخرَ محرَّم ولكن لا يقدح في الخروج عن العهدة. و أما المعارضة الأولى (1) فيجاب عليها: بأن النهي دلَّ على أن المنهي عنه مغايرٌ للمأمور

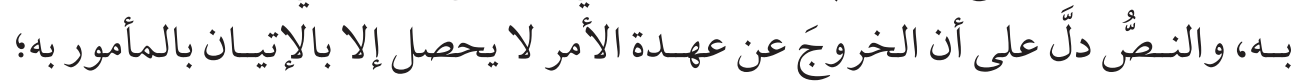

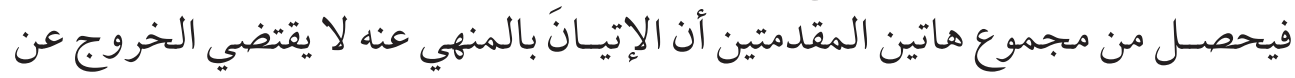
العهدة.

و أما المعارضة الثانية(r) فيجابُ عليها: بأننا لا نسلِّمُ أن النهي في الصور التي ذكرتموها

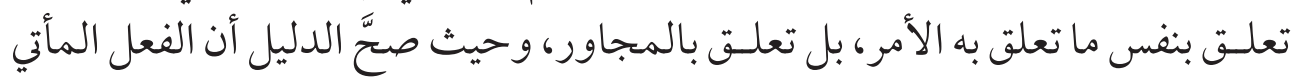

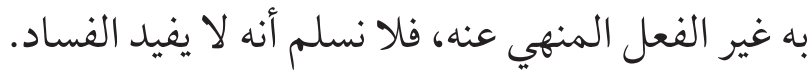

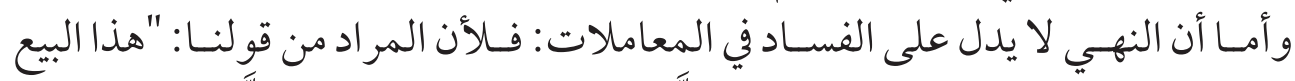

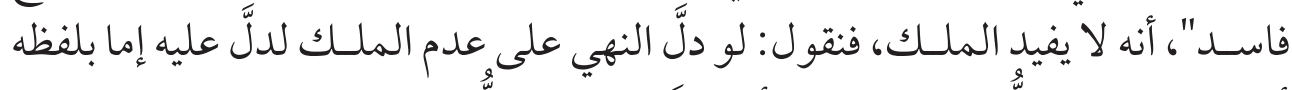

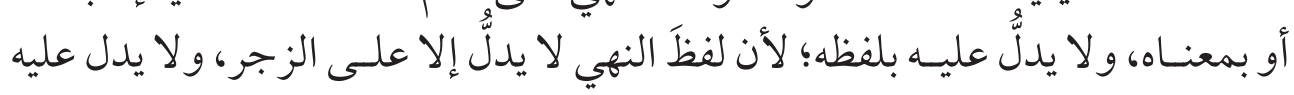

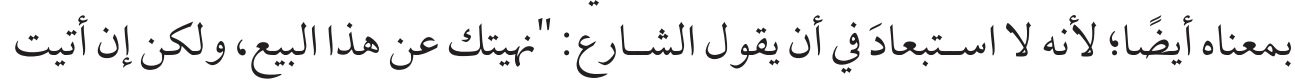
بــه حصـل الملك": كالطلاق في زمان الحيض، و البيع وقت النداء"، و إذا ثبت أن أن النهي

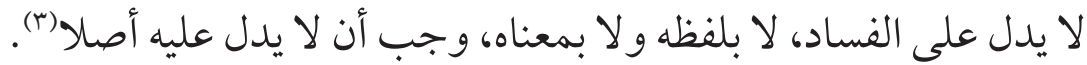

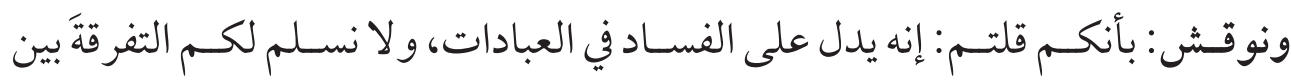

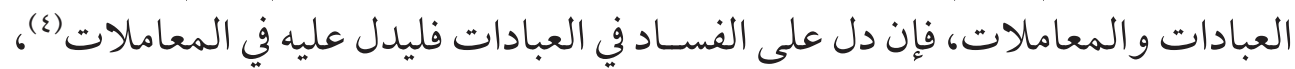

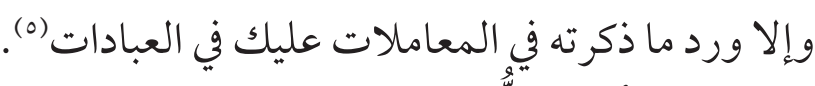

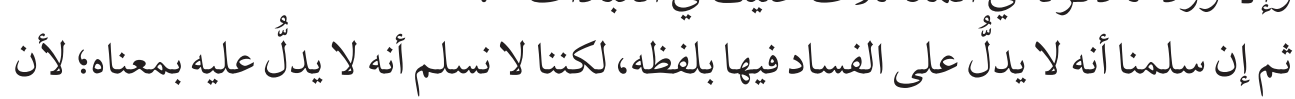

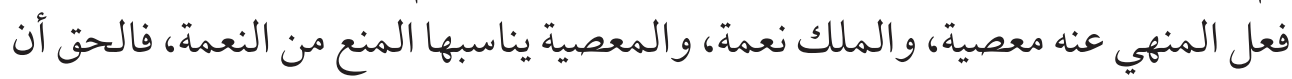

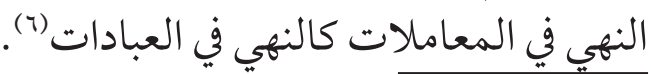

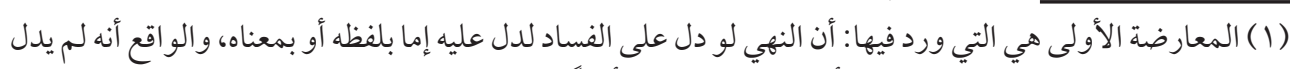

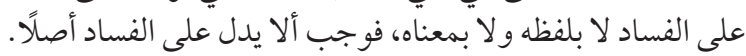

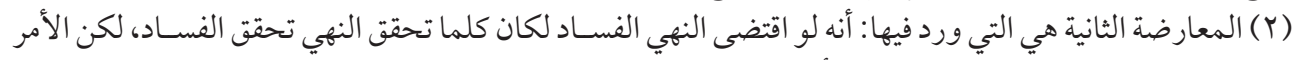

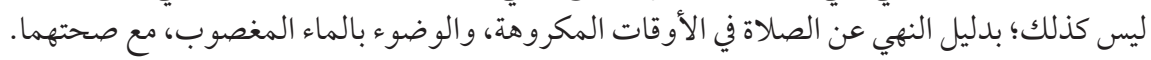

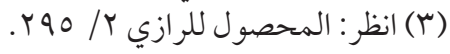

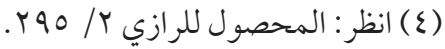

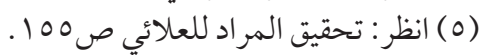

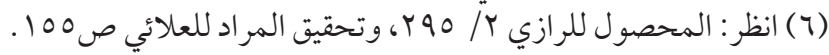


كما أن المنهي عنه لا يجوز أن يكون سـبًِا ومنشـأُ للمصلحة، و إلا لكان النهي منعًا من المصلحة، وهو لا يجوز (1).

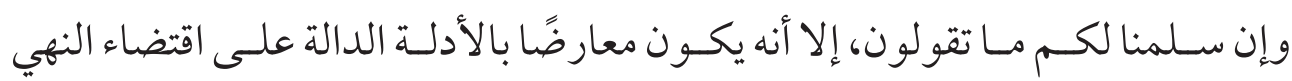

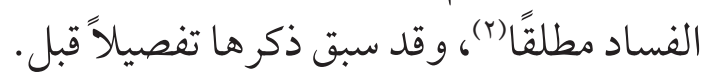

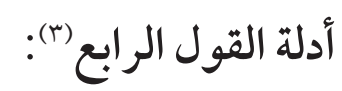

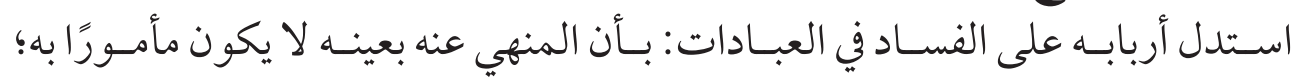

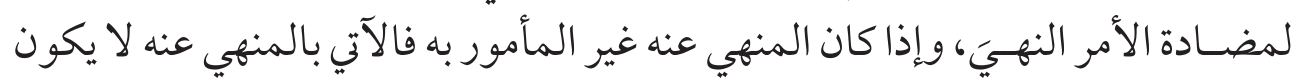

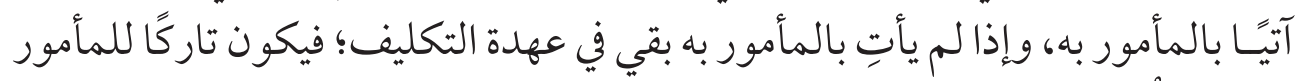

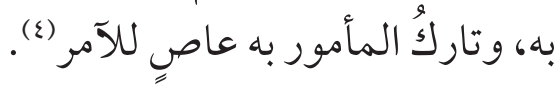

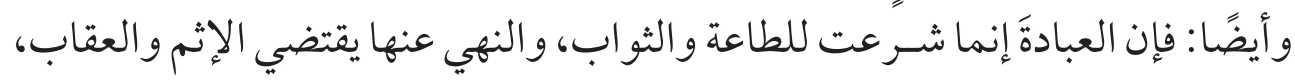

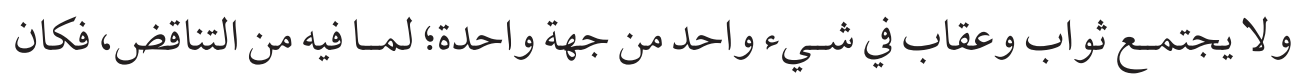

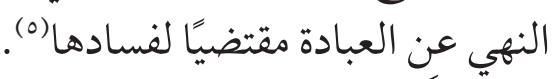

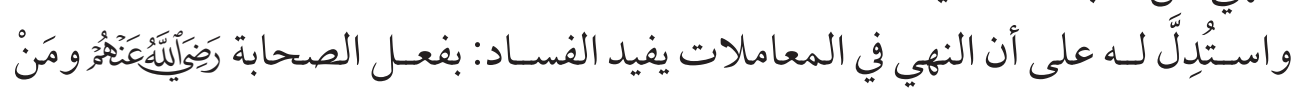
بعدهم من التابعين، فإنهم قد تمسكوا في فساد الربا بمجرد النهي الوارد في قوله تعالى:

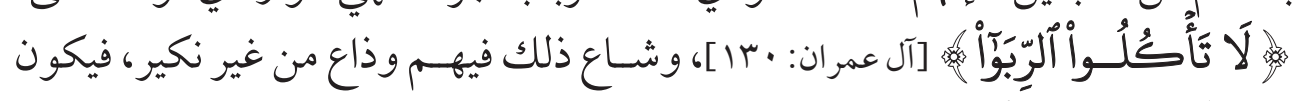

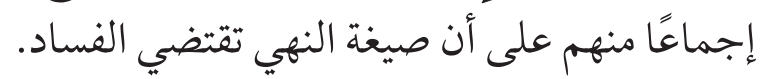

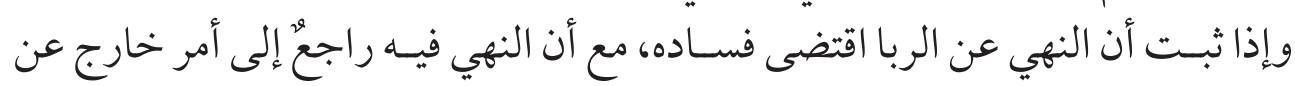

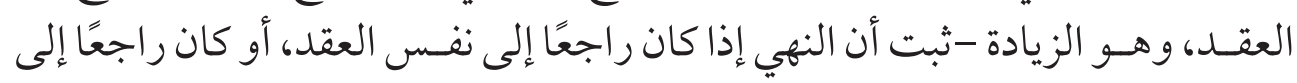
ركن فيه يدل على الفساد من باب أولى (ج).

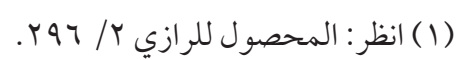

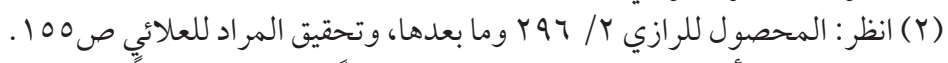

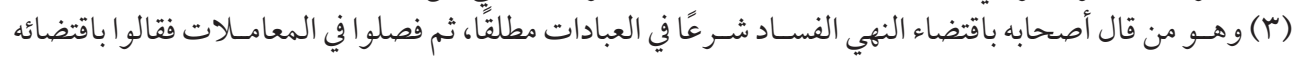

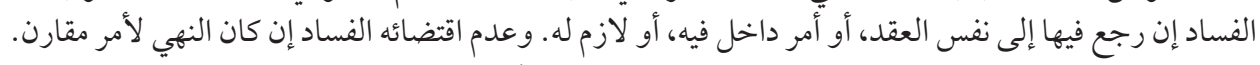

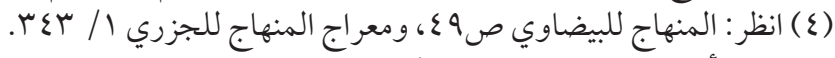

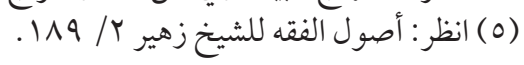

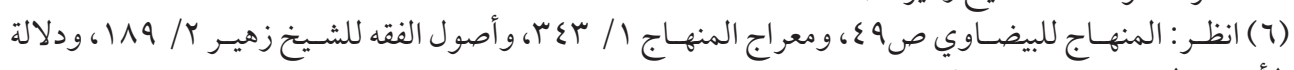

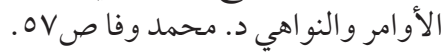


و أمـا أن النهي لا يدلّّ على الفسـاد في المعامـلات، إذا كان النهي راجعًا إلى أمر خارج

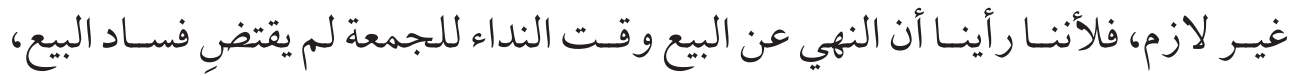

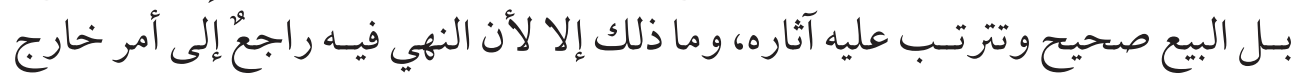

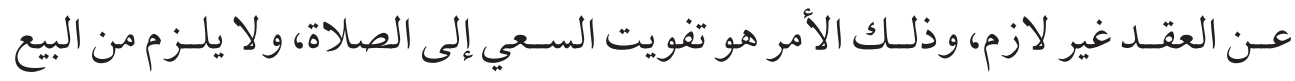

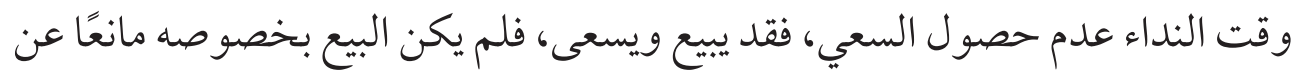

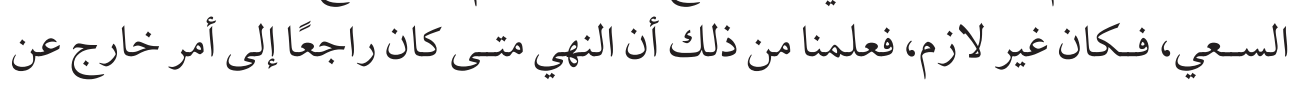

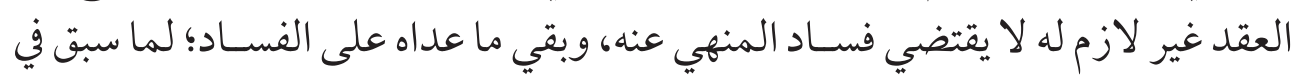

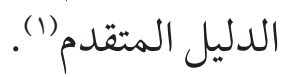
دليل القول الخامس: من فصَّلو ا فقالو ا: إن كان النهي عن الشيء لمعنى في عينه فهو يقتضي الفساد، وإن كان

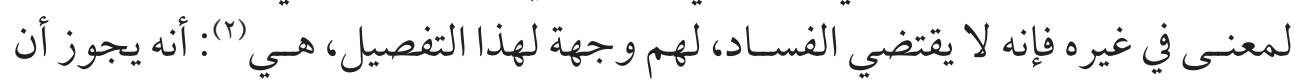

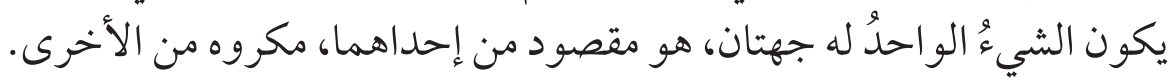

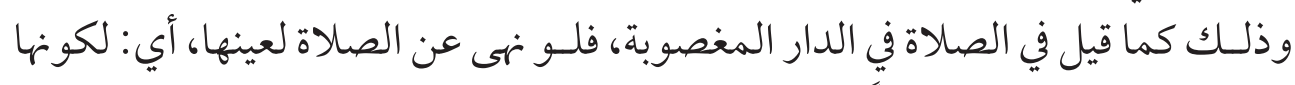

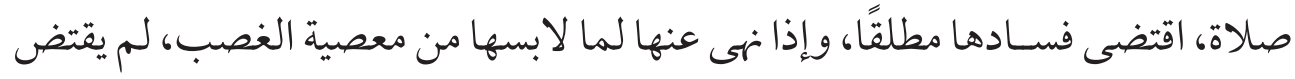
فسادها.

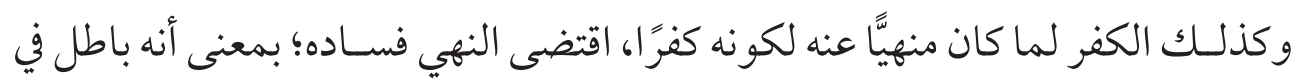

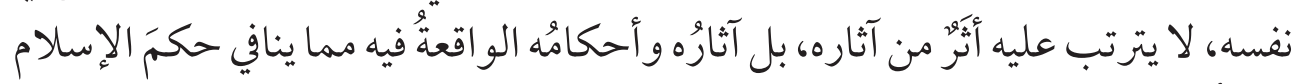

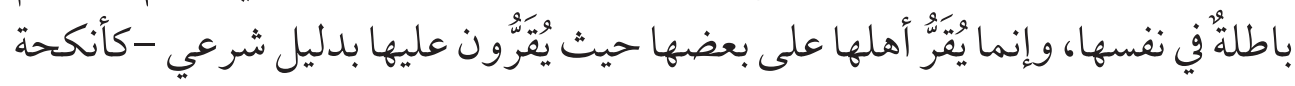

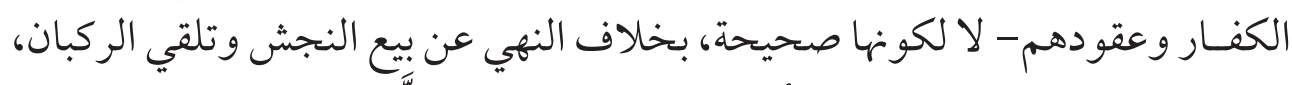

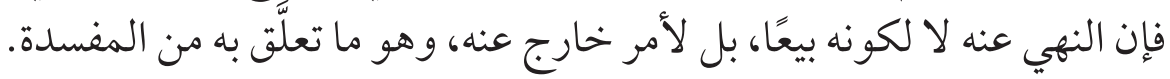

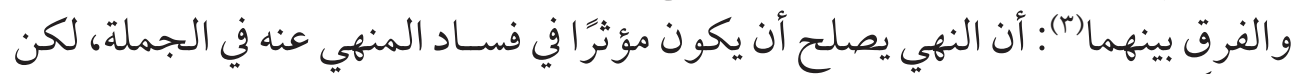

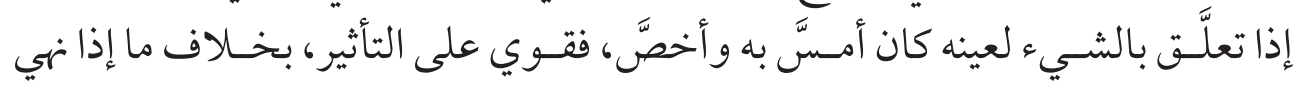

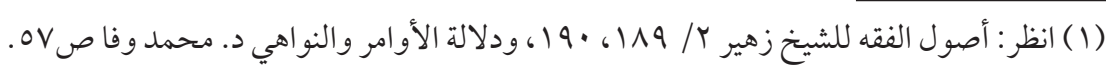

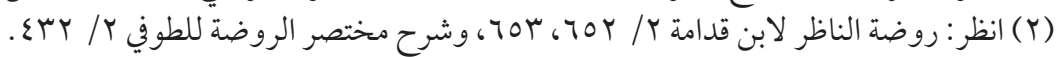

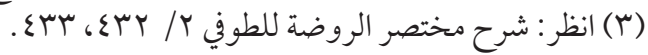

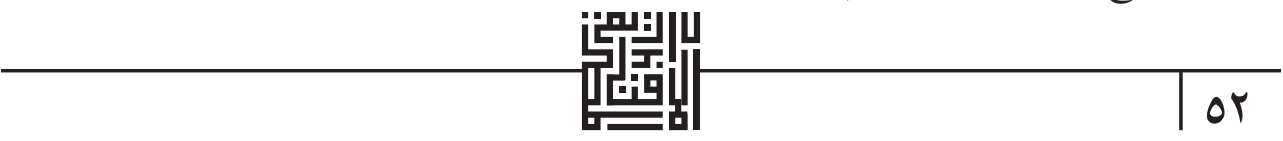


عنــه لغيره، فإن تعلقه به ضعيـف، والأصل يقتضي صحة أفعال العقلاء، فلا يقوى هذا السبب الضعيف على رفع هذا الأصل القوي.

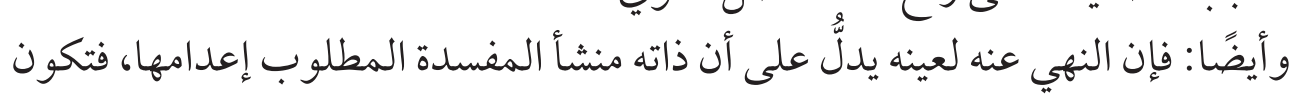

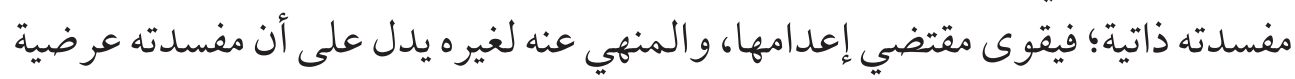

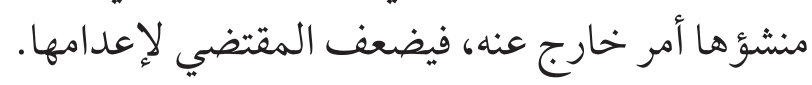

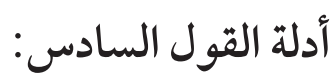

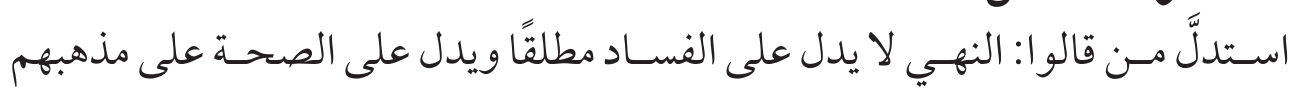
بأدلة، منها: - (أستصن 1 - أن النهي لو لم يدل على صحة المنهي عنه شـرعًا، لكان المنهي عنه غير الشـرعي، و التالي باطل بالاتفاق.

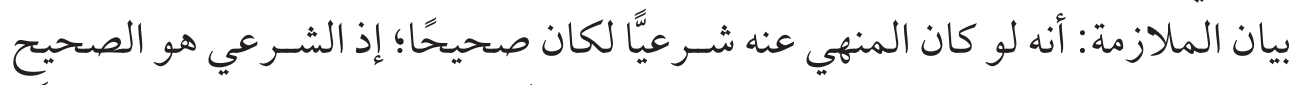

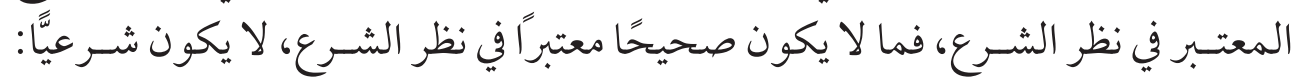

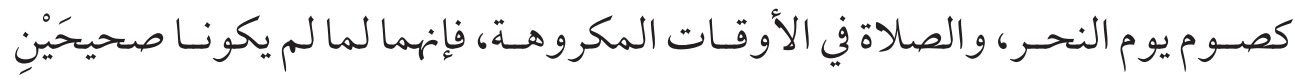

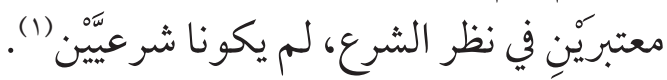
وأجيب: بأن الشرعي ليس معناه المعتبر في نظر الشرع، بل الشرعين الشرعي هو ما يسميه الشارع

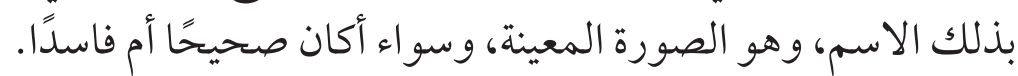

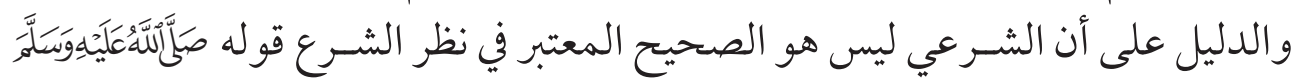

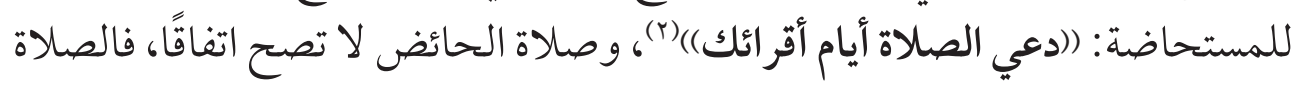

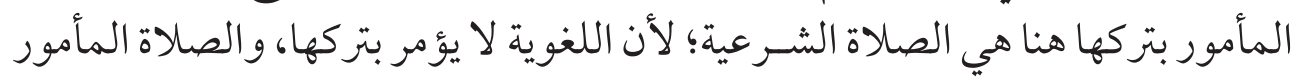
بتركها فاسدة غير معتبرة في نظر الشرع.

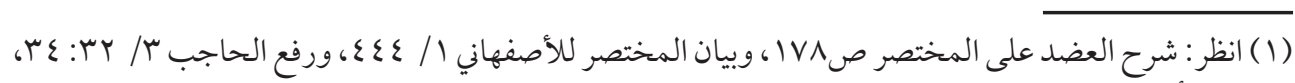

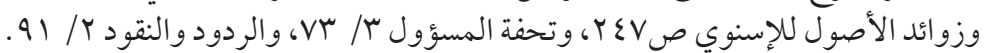

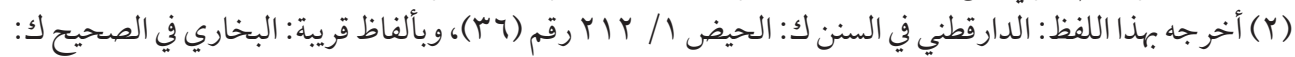

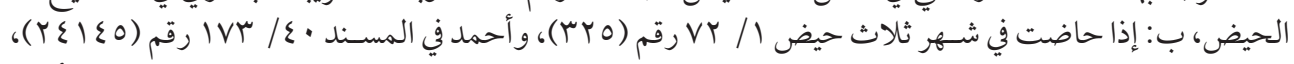

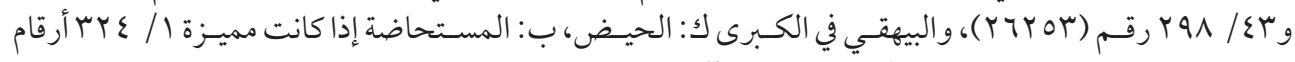

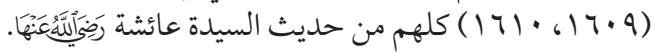




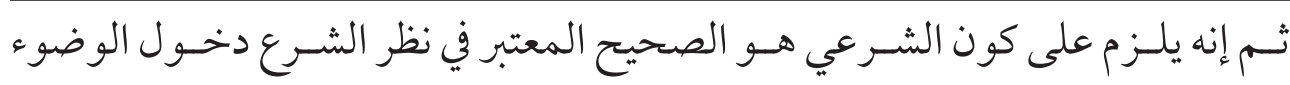

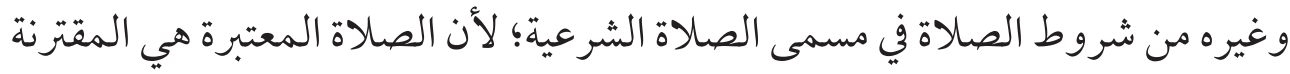

بشروطها، وهذا باطل بالاتفاق (1).

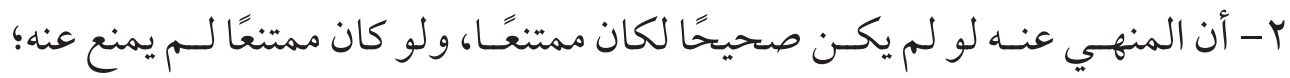

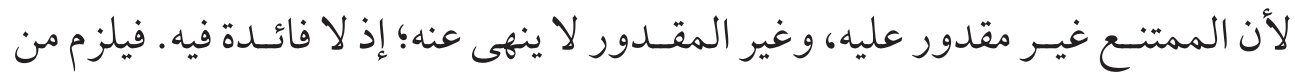

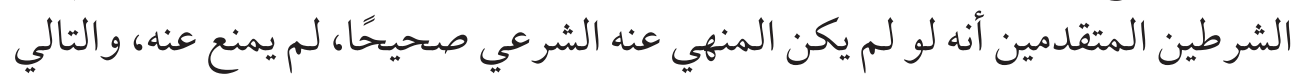
باطل بالضرورة. وأجيـب: بأن الامتناع لأجل النهي الوارد عليه، لا لـذات المنهي عنه، فإن النهي تعلق

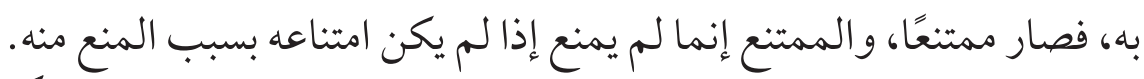

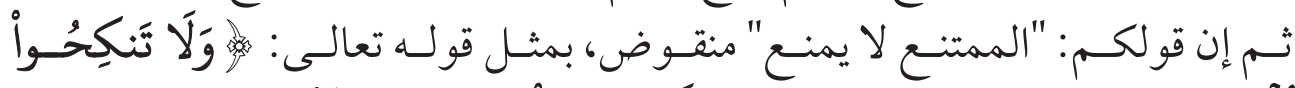

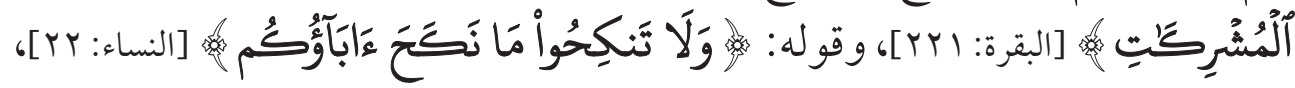

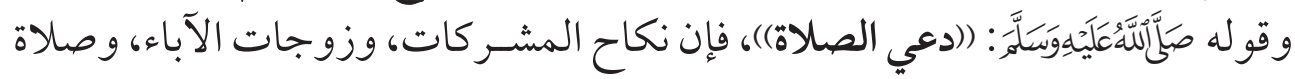

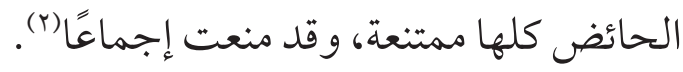

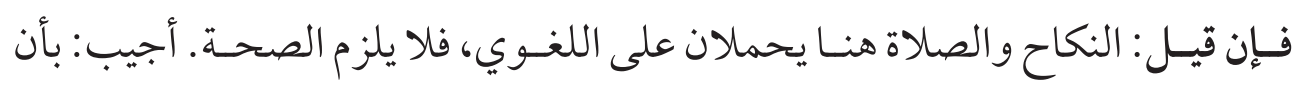

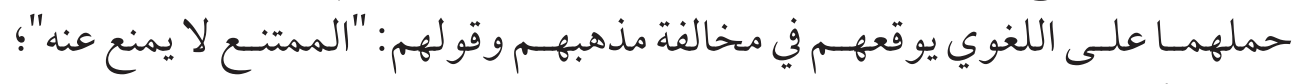
وذلك لأن النكاح اللغوي الذي هو الوطء ممتنع في الشرع ومنهي عنه، فيكون الممتنع قد منع، فلا يججوز حمله على اللغوي.

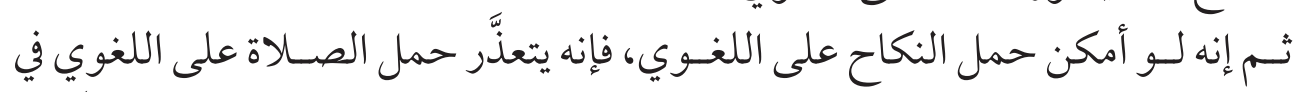

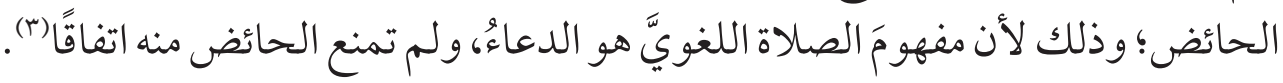

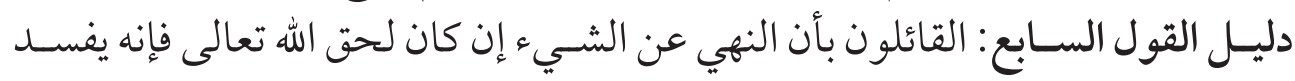
المنهي عنه، وإن كان لحق العبد فلا يفسـد المنهـي عنه، دللو العلى تفصيلهي إنهم هذا بأن:

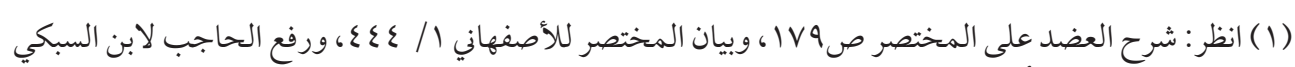

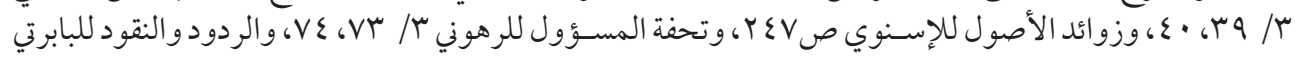
$.9 r / r$

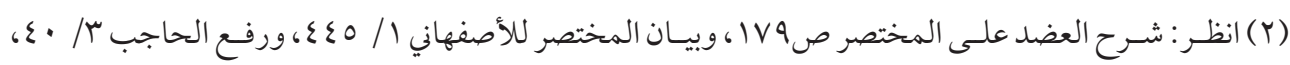

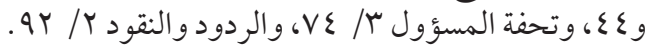

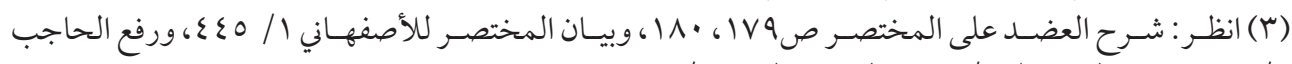

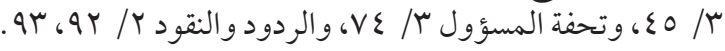




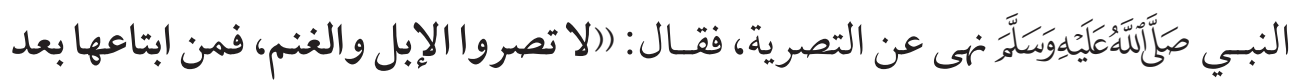

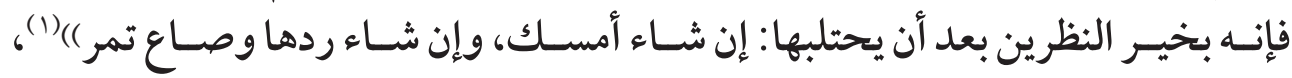

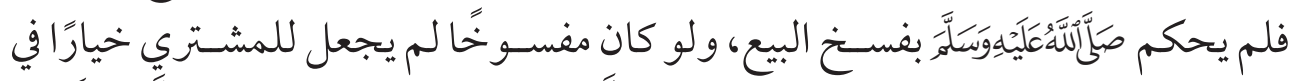

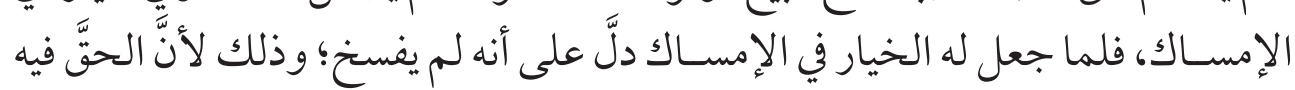

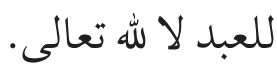

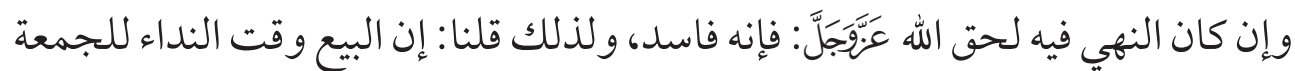

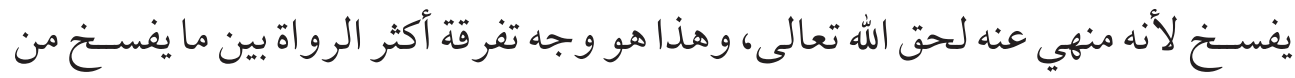

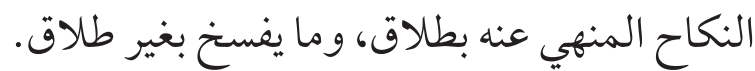

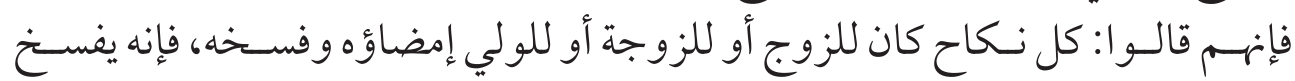

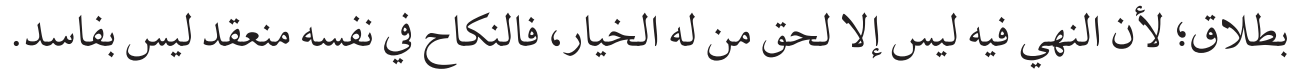

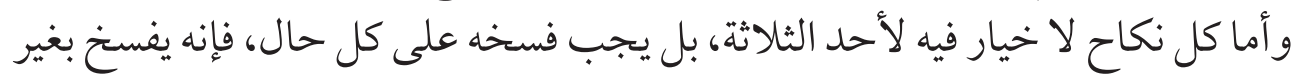

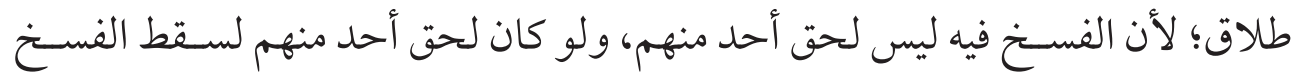

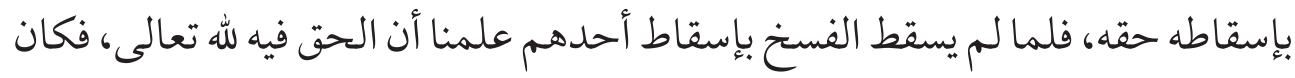

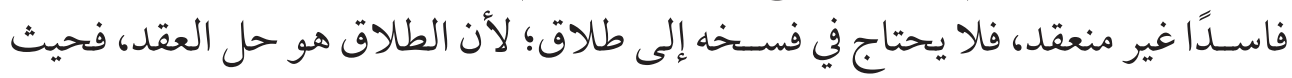

$$
\text { الا عقد فلا حل (r). }
$$

الراجح -و الله أعلم- هو قولُ القائل بأن النهي يقتضي الفساد؛ لقوة أدلتهم، و الرد على الرى

$$
\text { ما استدل به غيرهم. }
$$

1 - الأقو ال السابقة في المسألة هي أظهر ما ورد فيها، وهناك أقو ال غيرها، لكن بالتأمل

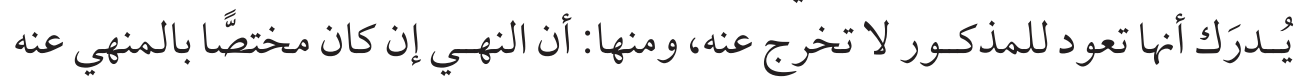

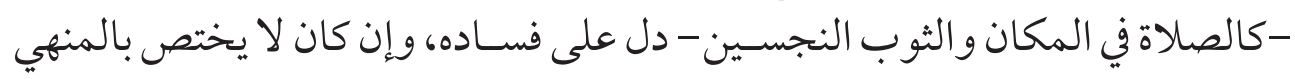
عنه -كالصلاة في الدار المغصوبة، وفي الثوب الحرير - فإنه لا يدل على فساده.

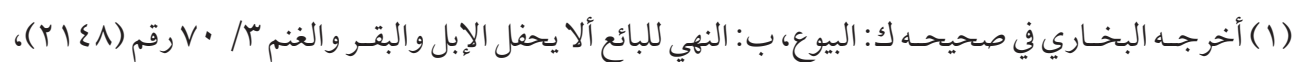

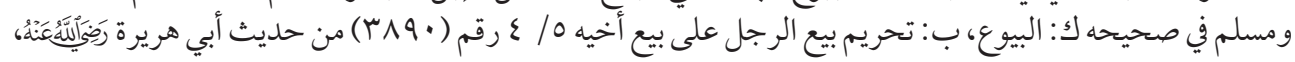

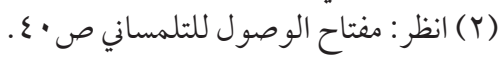




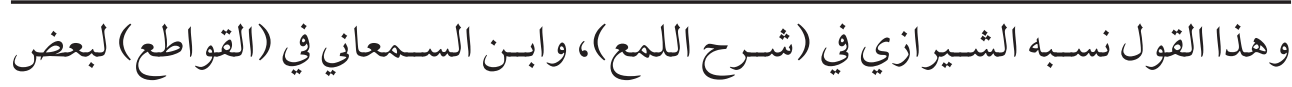

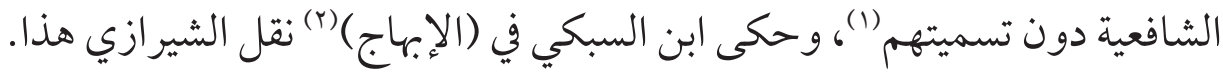
وهذا القول بالتأمل نجد أنه لا يخرج عن التفصيل السـابق، بين النهي عن الشيء لعينه لعينه أو لغيره. ومنها: أن كل ما ثبت مشروطًا بشرط من عبادة أو معاملة، ثم أتى مخالفًا لمورد الشريعة

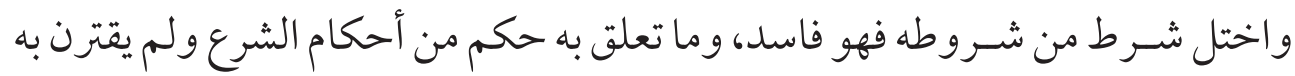

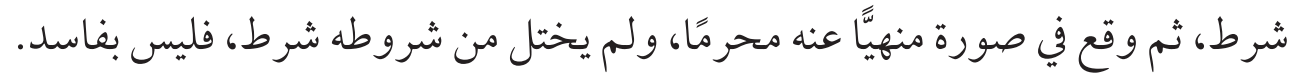

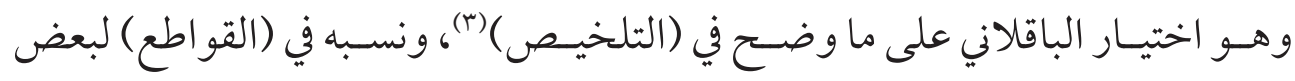

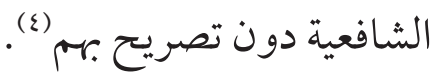

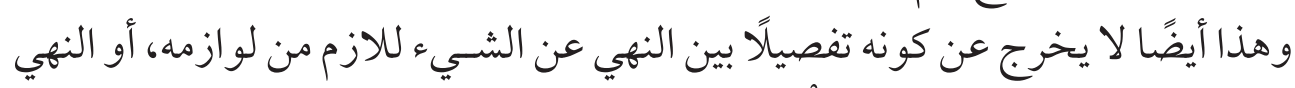

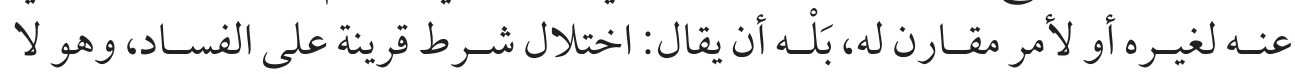
خلاف فيه.

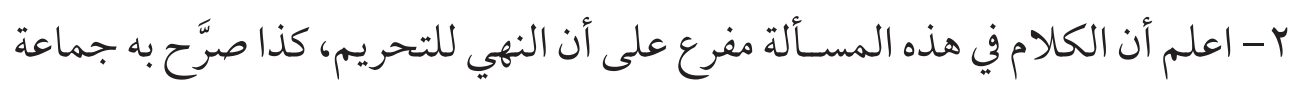

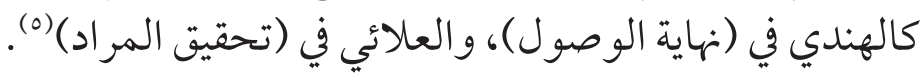

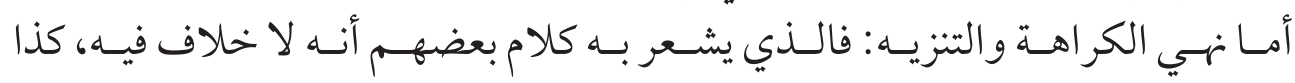

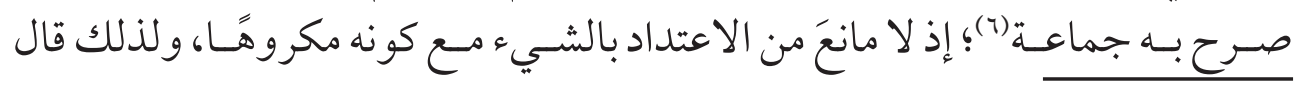

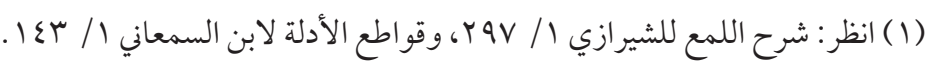

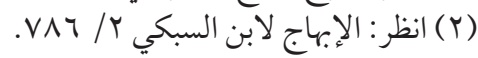

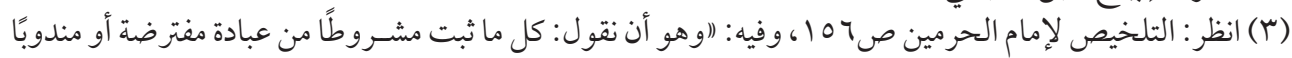

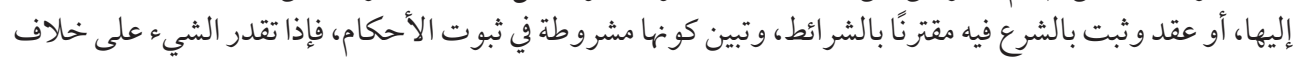

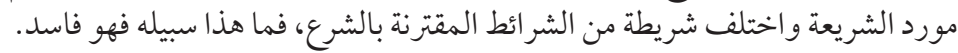

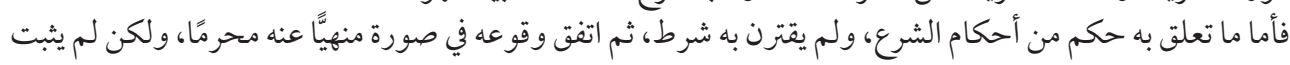

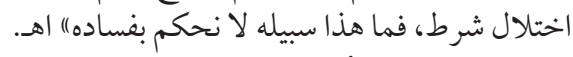

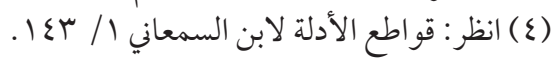

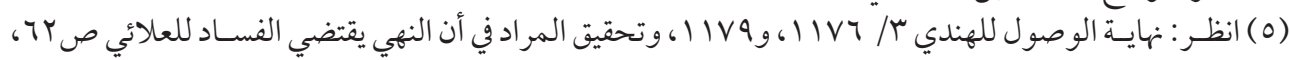

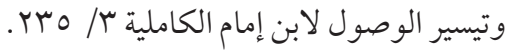

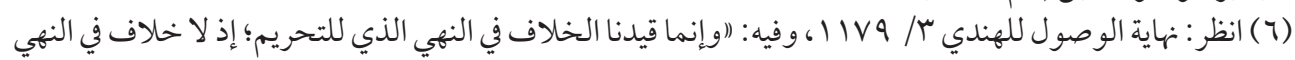

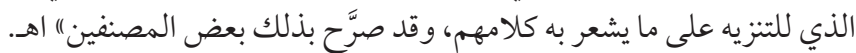

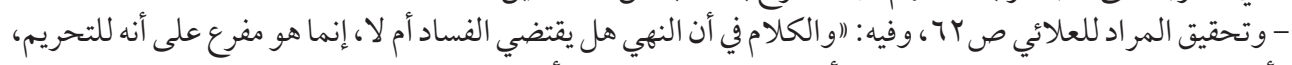

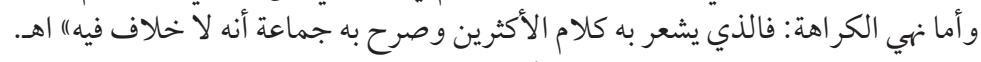

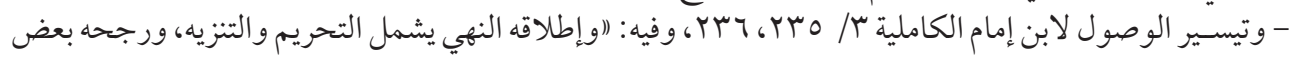




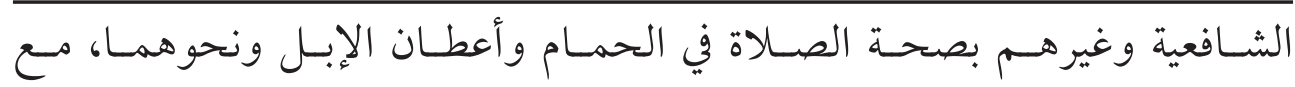

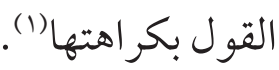
و هؤ لاء و إن صرحو ا بأنها مفرعة على أن النهي للتحريم، فقد فرعه آخرون عليهما معًا، أي التحريم والتنزيه (r) ب- ينبغـي أن يكــــن الخـالاف في النهي غير المقـترن بقرينة تدل على الفســاد، كالنهي الدال على المنع من الشيء لخلل في أركانه أو في شروطي لئه

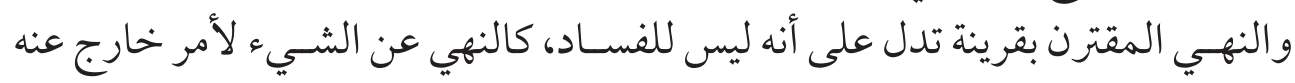
مجاور له.

ففي هذين النهيين ينبغي ألا يكون خلاف، أو إن كان فيه خلاف -على ما يشعر به كلام

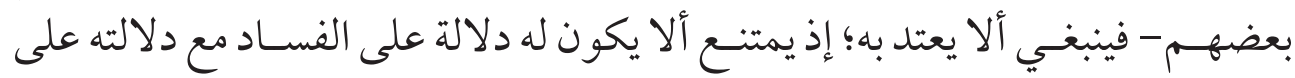

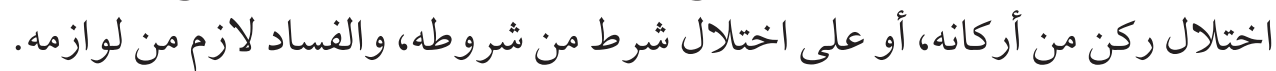

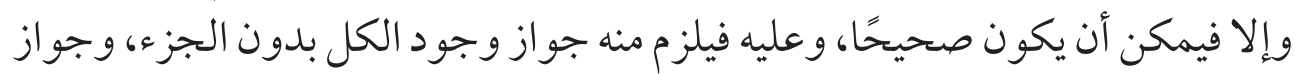
وجود المشروط بدون شرطه، وهو ممتنع (r).

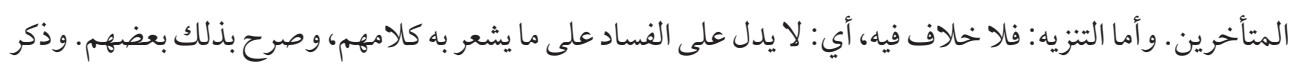

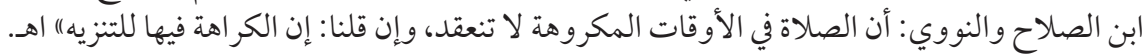

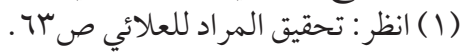

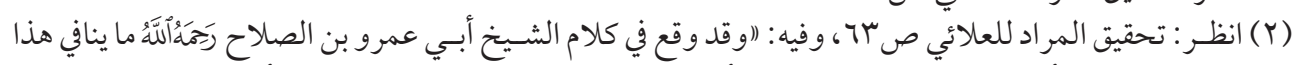

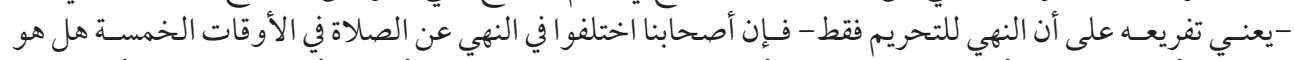

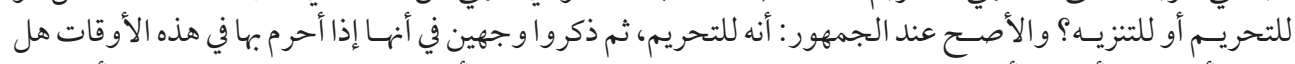

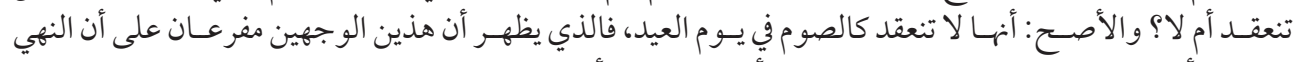

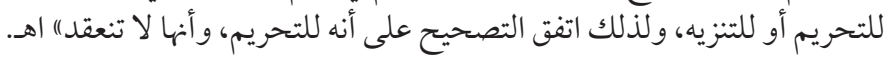

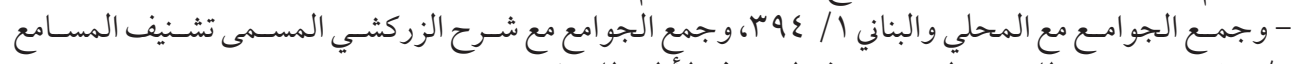

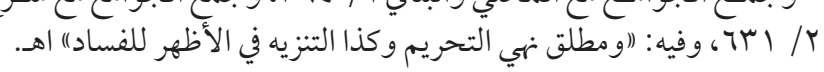

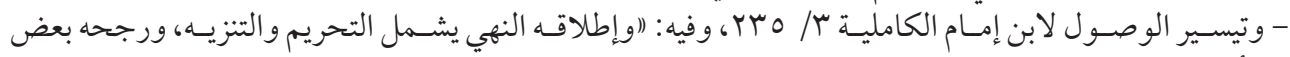

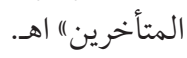

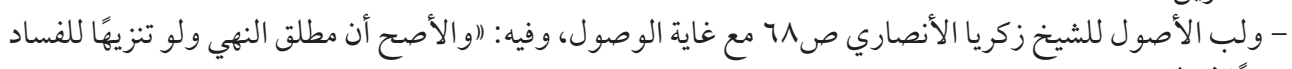

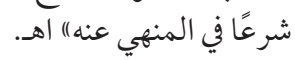

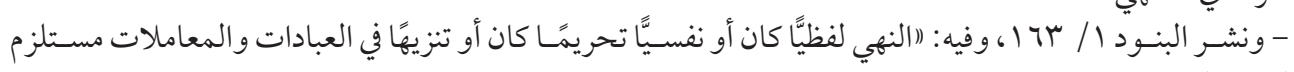

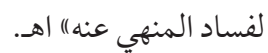

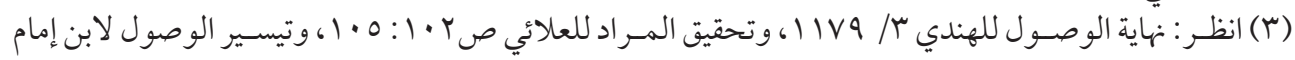

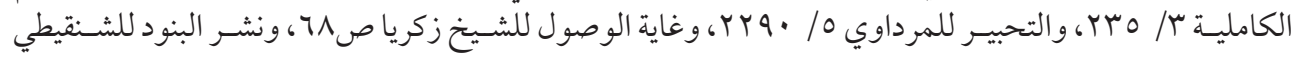


ع - قال الهندي في (نهاية الوصول): "وقد عرفت فيما سـبق معنى الفسـاد في العبادات و المعاملات، وأنه لا اختلاف في معناه في المعاملات، وإنما الاختهاف ولاف فيه في في العبادات.

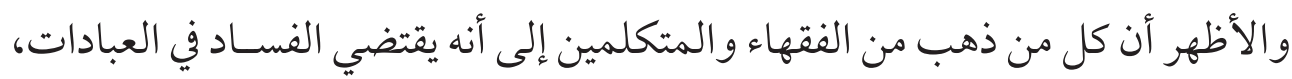

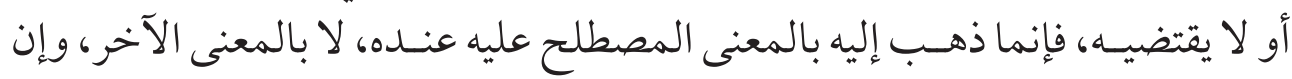

كان الأمر في الآخر على خلاف هذا على ما عرفت ذلك ذلك، فاعرف ذلك الك" اهـ (1).

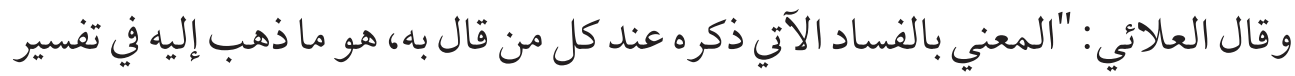

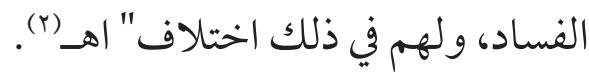
0 - مما يتخرج على الراجح في المسألة:

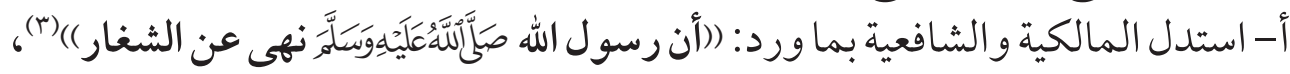
على فسخ العقد في نكاح الشغار؛ بناء على أن النهي الوارد في الحديث يقتضي الفساد،

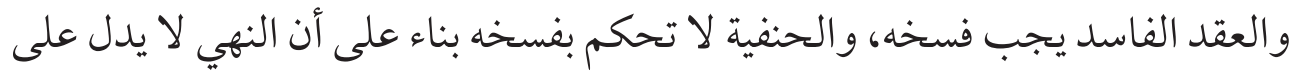

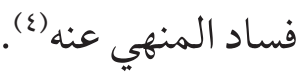

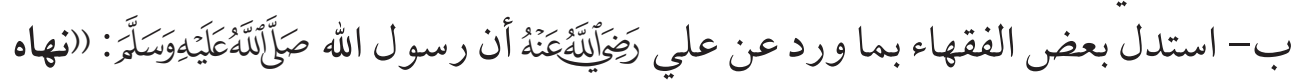

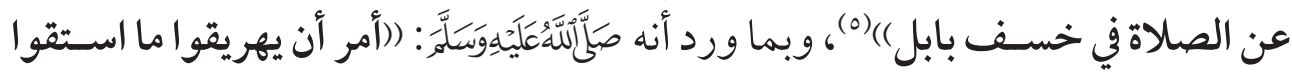

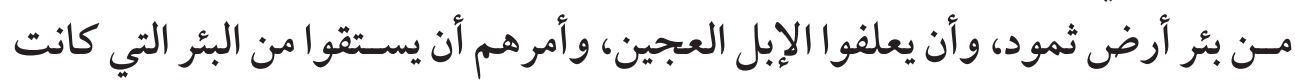

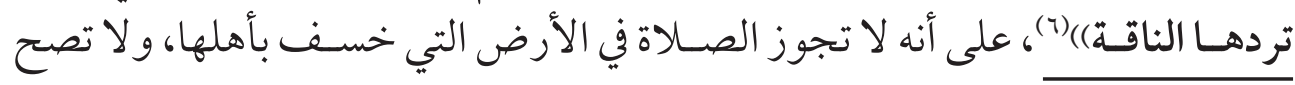

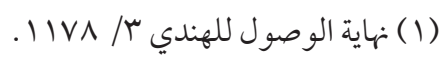

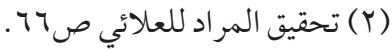

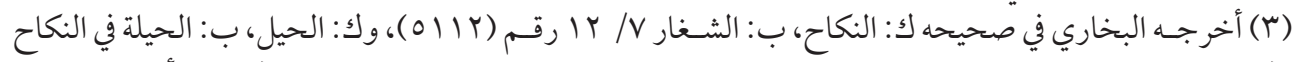

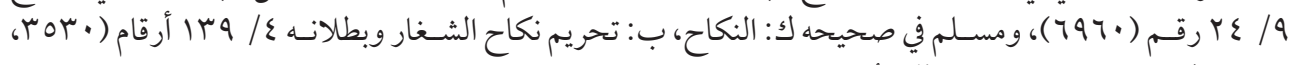

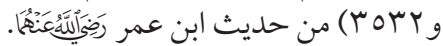

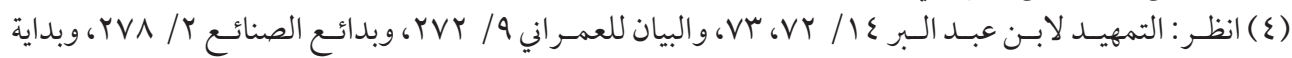

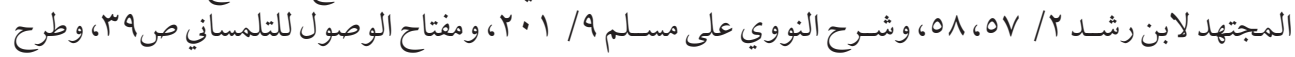

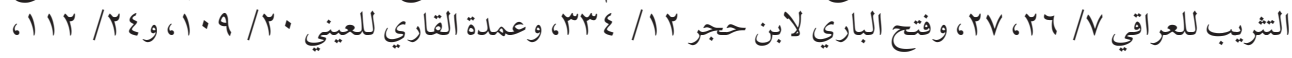

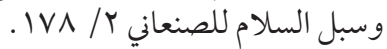

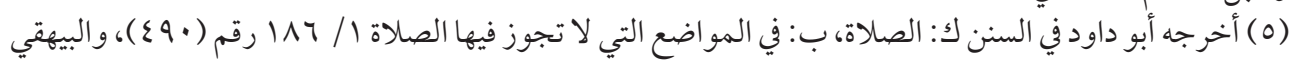

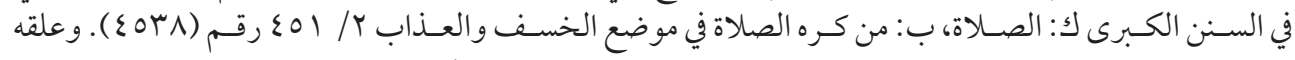

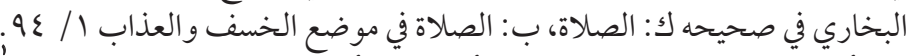

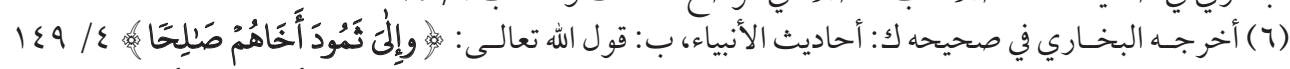

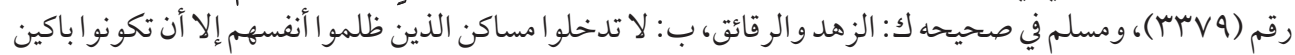

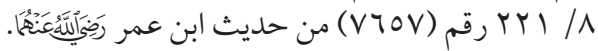




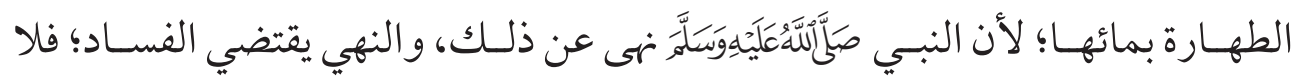
يصلى فيها، ولا يتطهر بمائها")

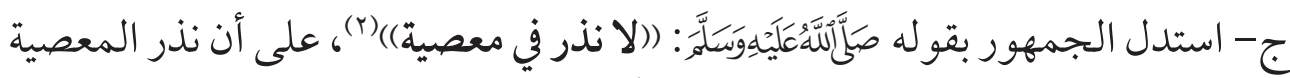

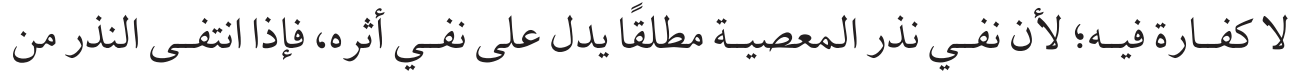

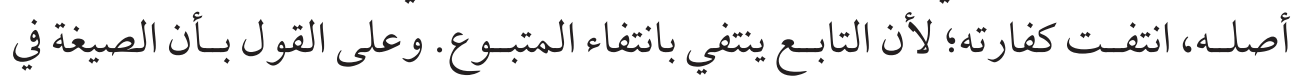

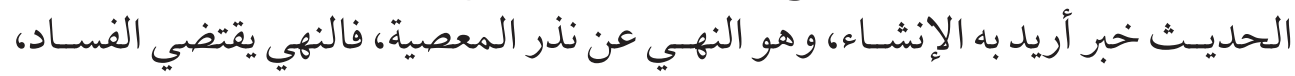

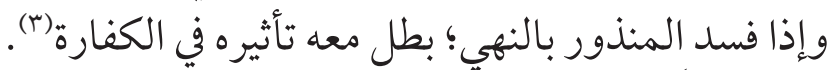

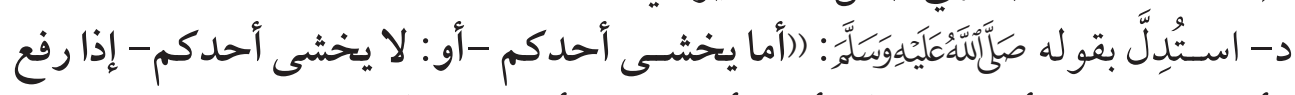

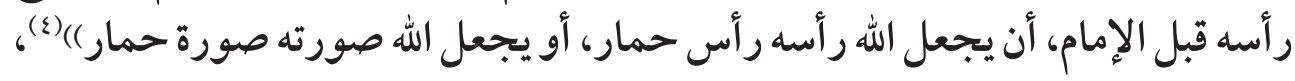

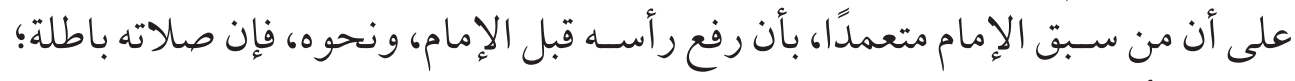

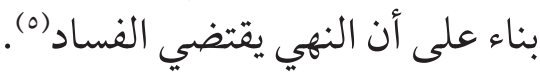

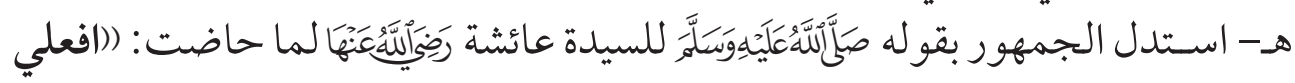

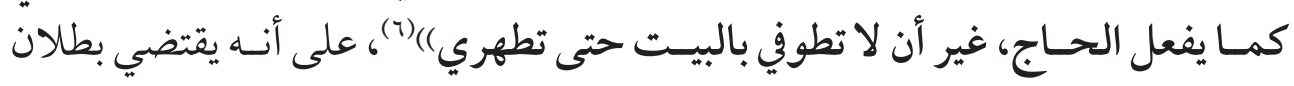

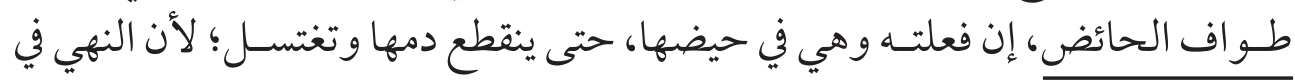

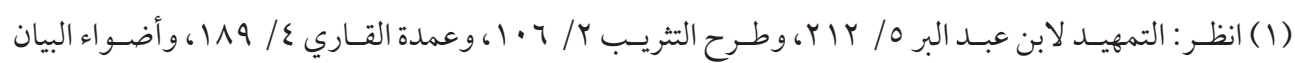

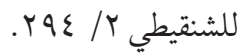

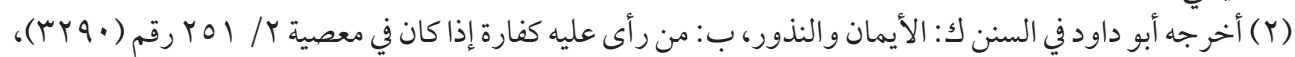

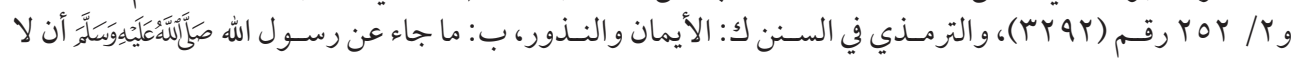

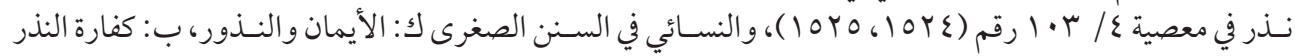

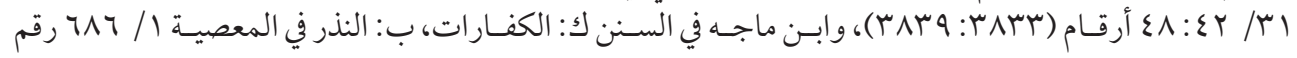

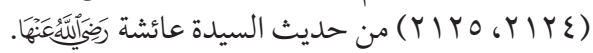

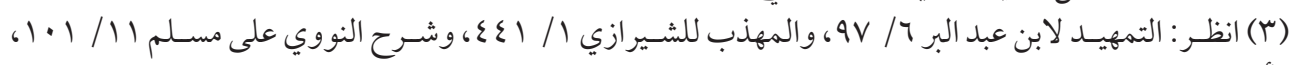

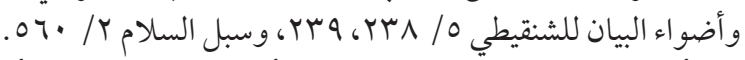

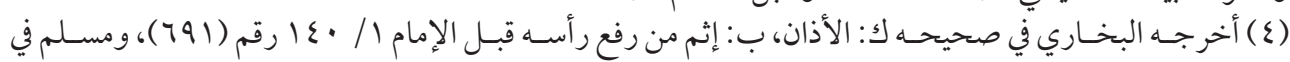

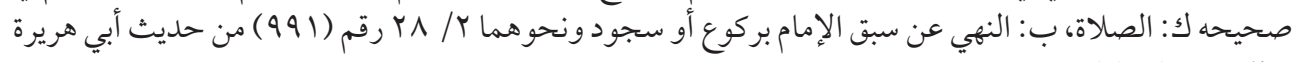

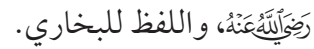

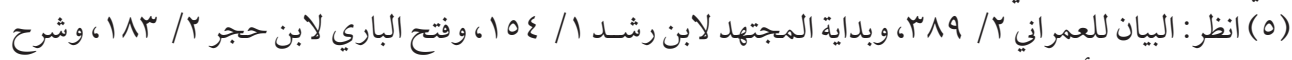

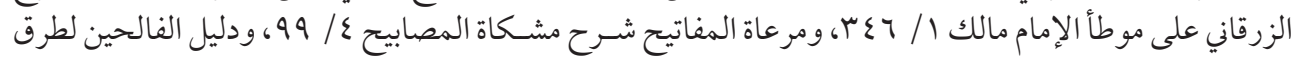

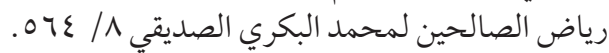

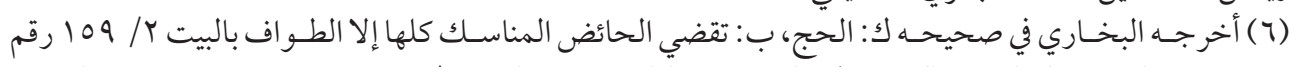

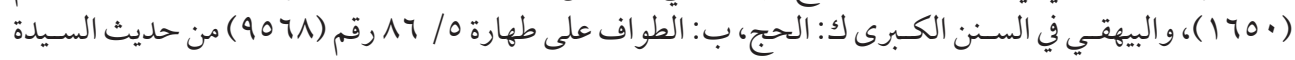

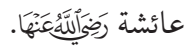




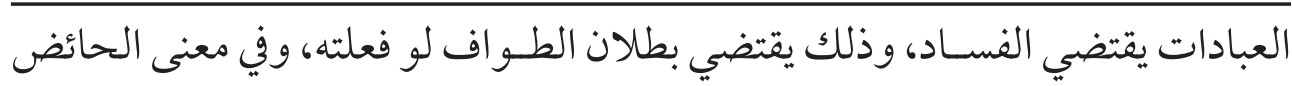
الجنب و المحدث؛ فتشترط الطهارة في الطو اف (1).

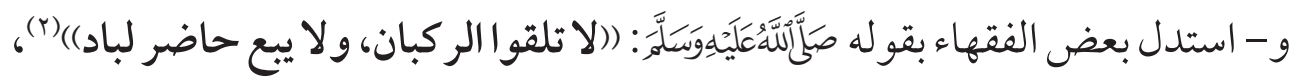
على بطلان هذا البيع ورده؛ بناء على أن النهي يقتضي الفساد مطلقًا (ب).

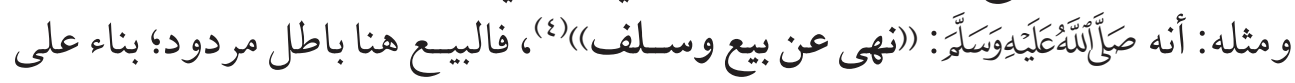

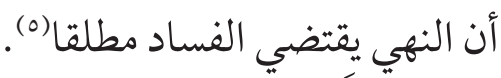

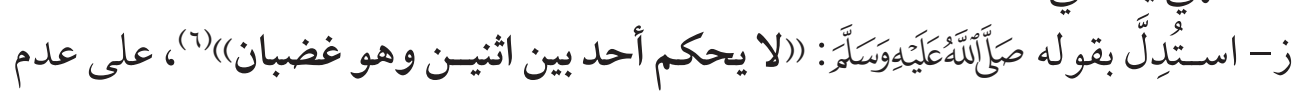

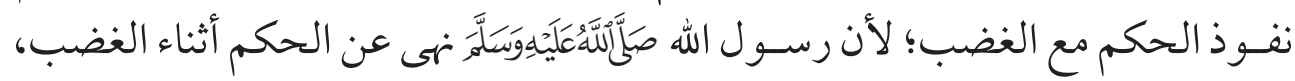
و النهي عن الشيء يقتضي فساده (v).

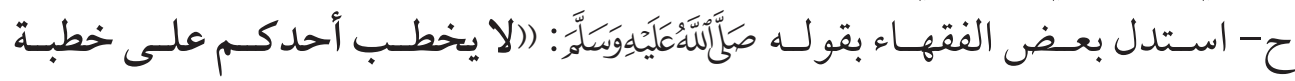

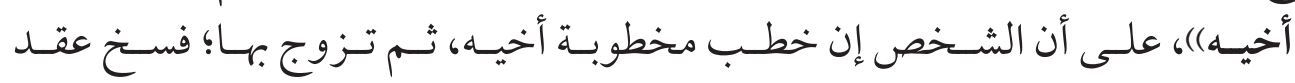

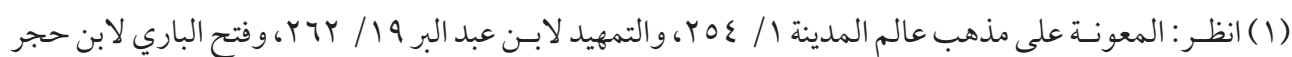

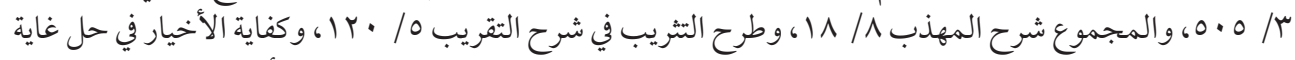

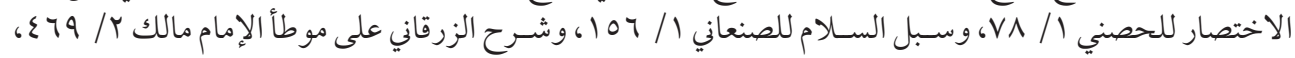

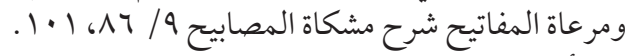

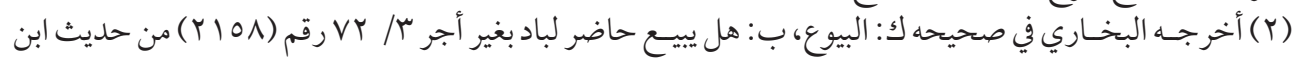

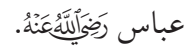

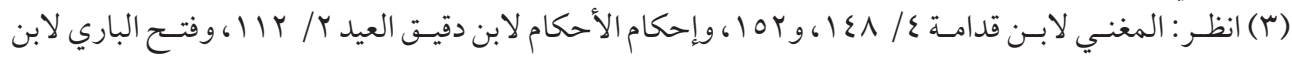

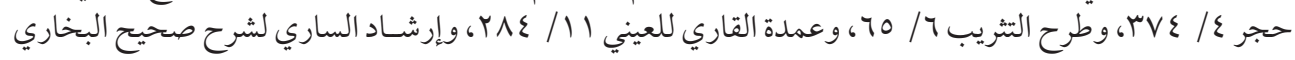

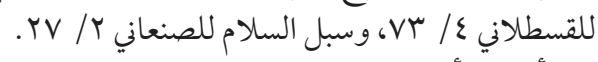

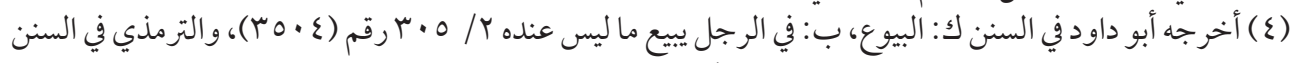

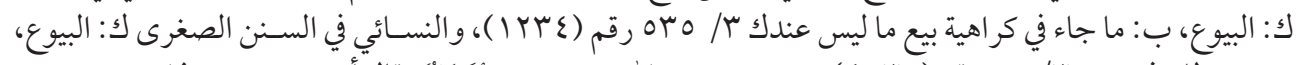

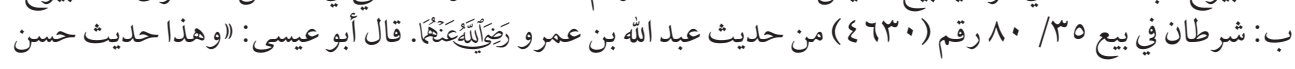
صحيح" اهـ: أهر

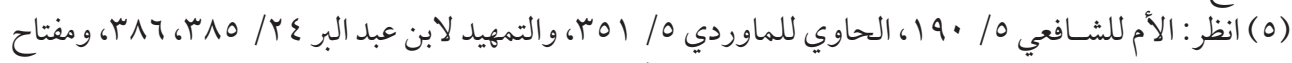

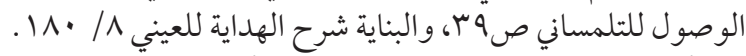

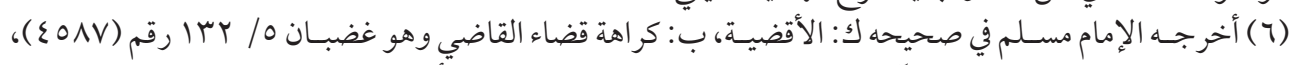

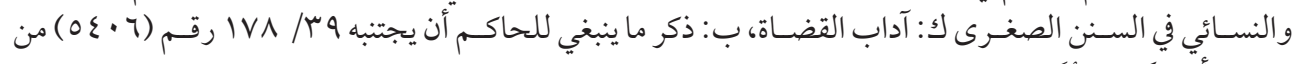

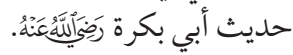

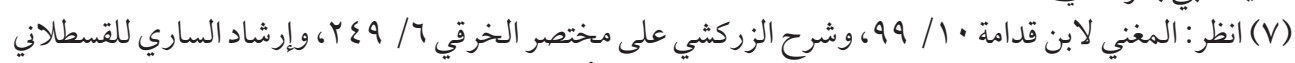
.

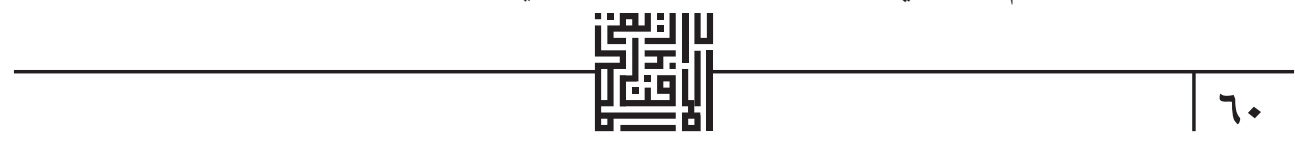




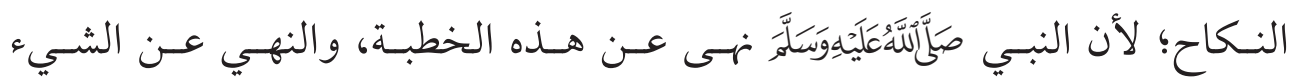
يقتضي فساده (1).

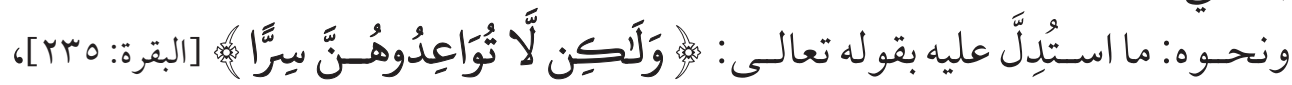

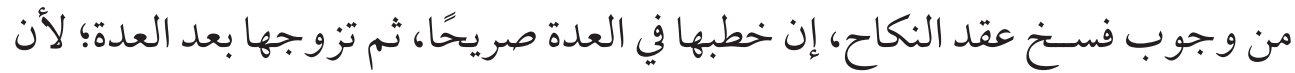

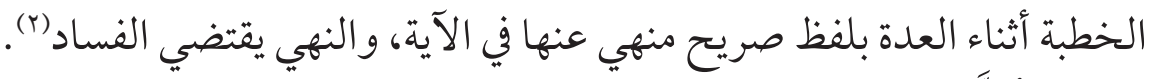

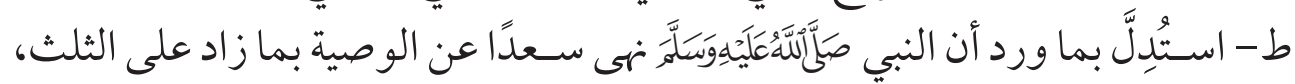

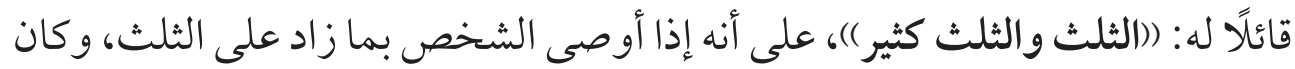

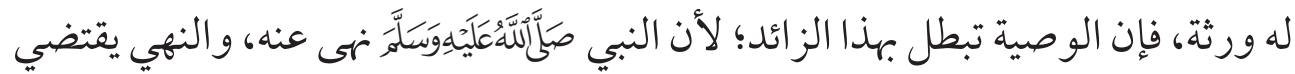

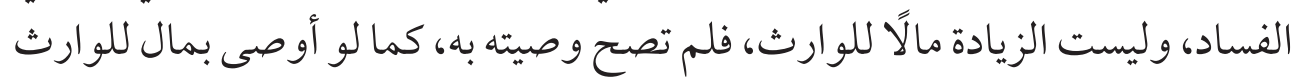

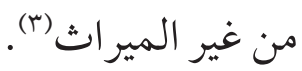

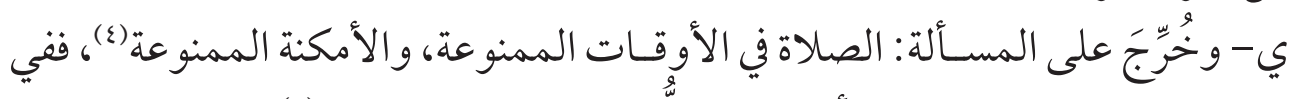

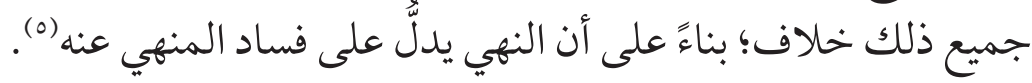

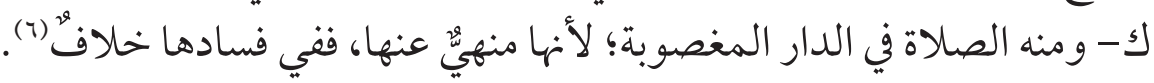

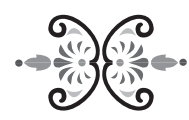

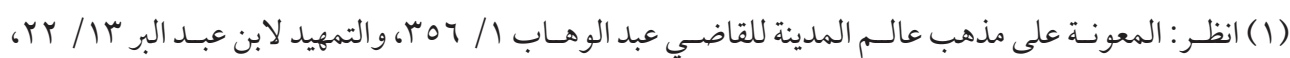

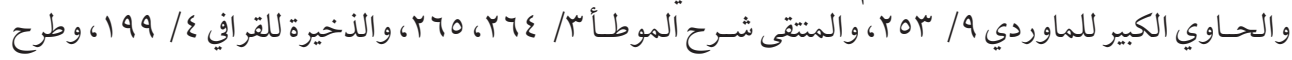

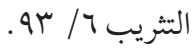

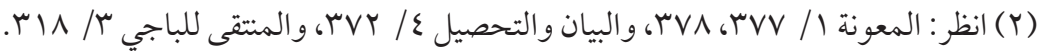

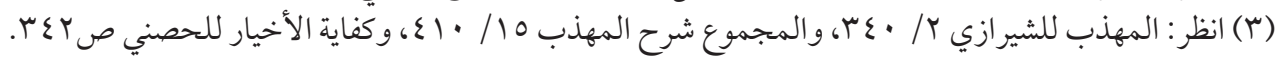

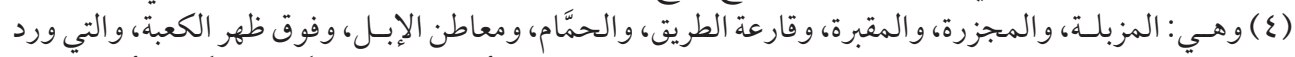

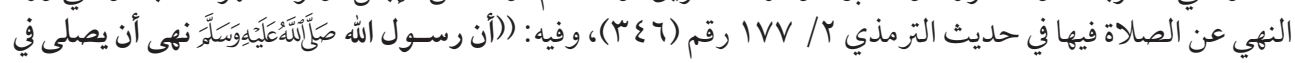

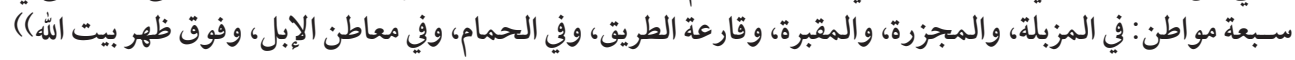

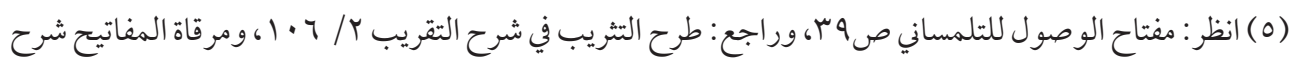

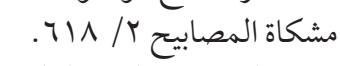

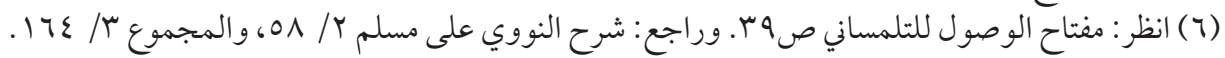




\section{المسألة التاسعة: مقتضشى النهي(1)}

المقصود بمقتضى النهي: المطلوب بالنهي، وهو الذي تعلق النهي به (r). وقد اختلف في المطلوب بالنهي على قولين:

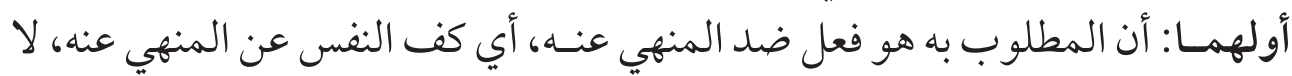

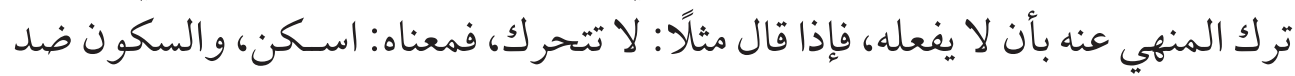

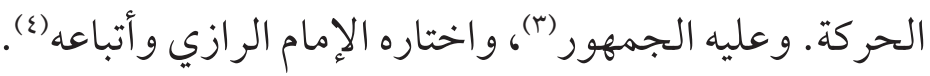

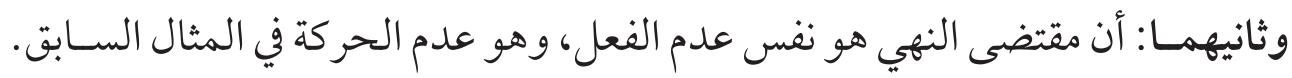

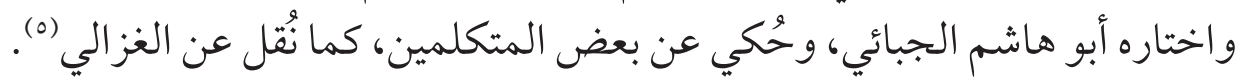
منشأ الخلاف في المسألة: أن النظر هل هو إلى صورة اللفظ فليس فيه إلا العدم، فإذا قال: لا تتحرك، فعدم الحركة

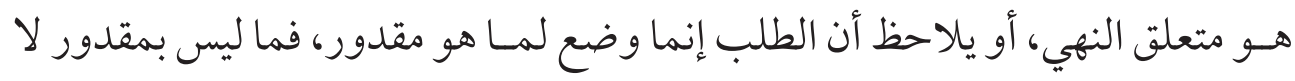

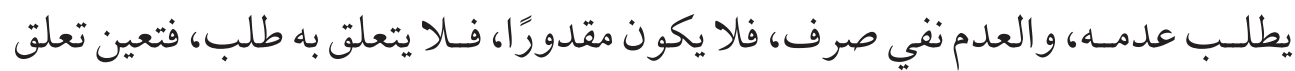

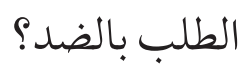

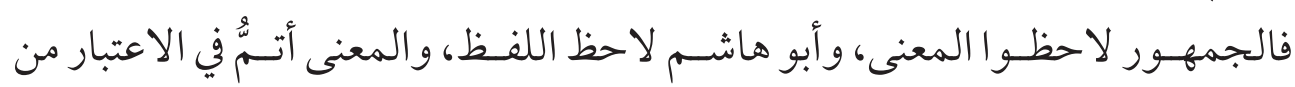

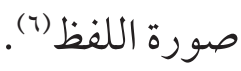

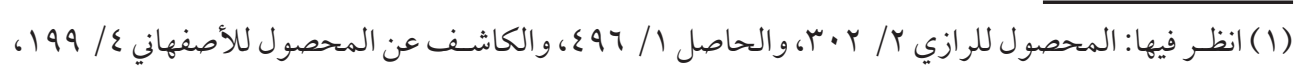

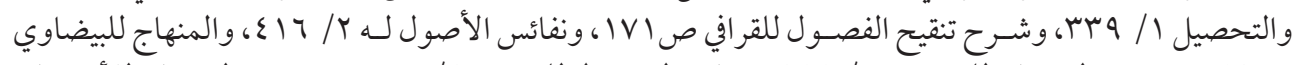

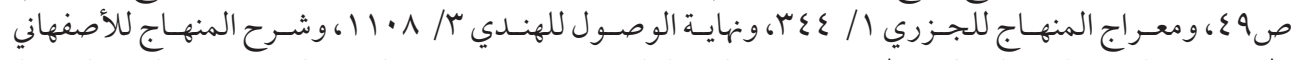

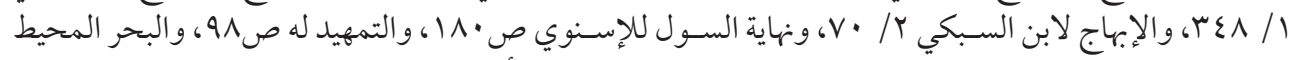

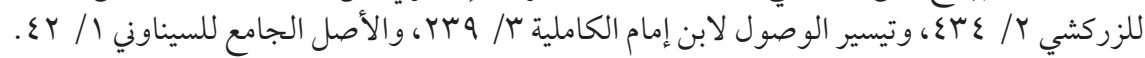

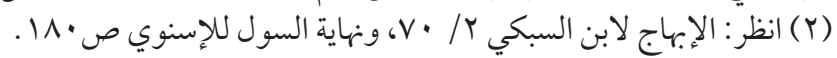

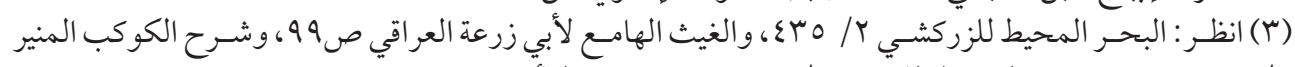

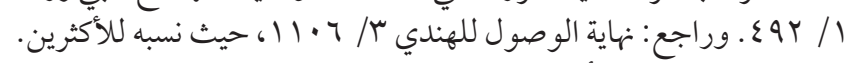

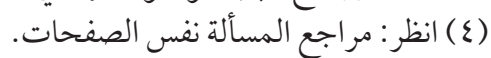

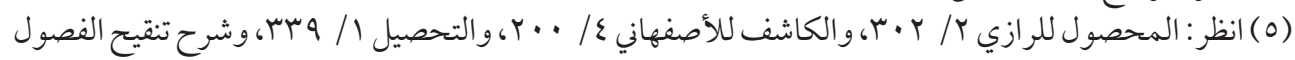

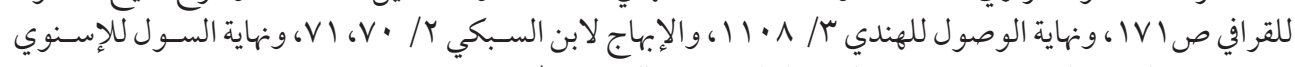

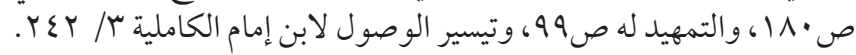

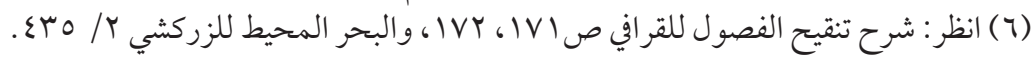




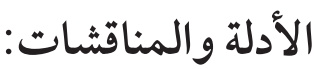

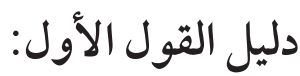

اسـتدل الجمهور على قولهم بأن النهي تكليـف، و التكليف لا يكون إلا بما يقدر عليه

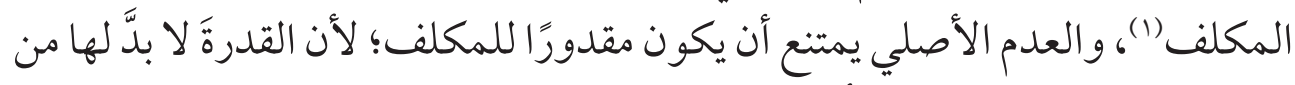

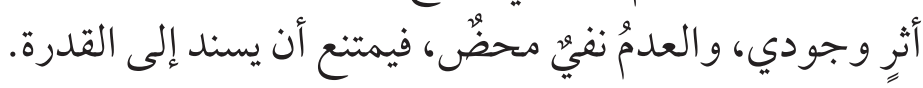

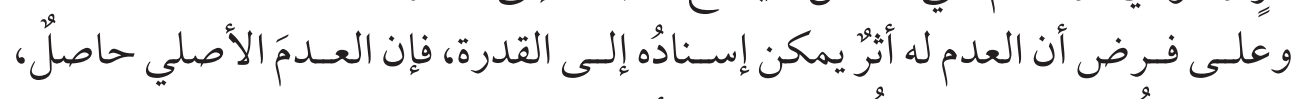

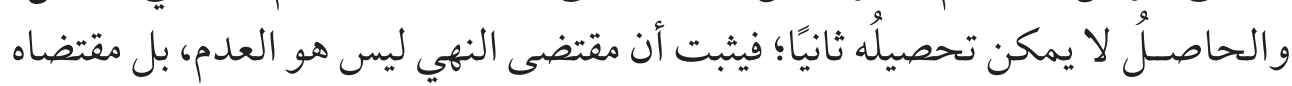

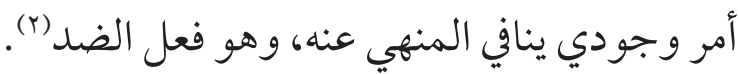

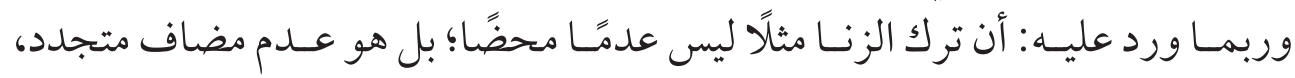
فيكون مقدورًا للمكلف ().

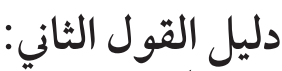

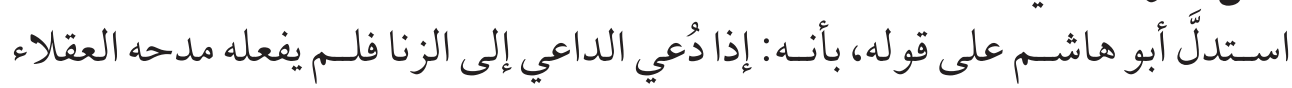

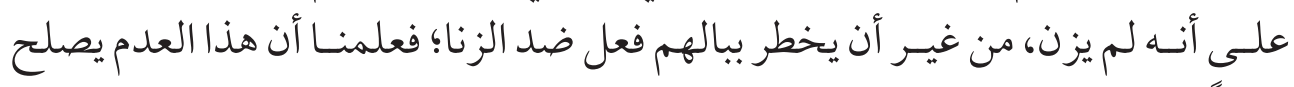
متعلقًا للتكليف أنه لمين. وأجيب: بأنهم لا يمدحونه على شيء في غير وسعه، والعدمُ الأصليُّ يمتنع أن يكون في

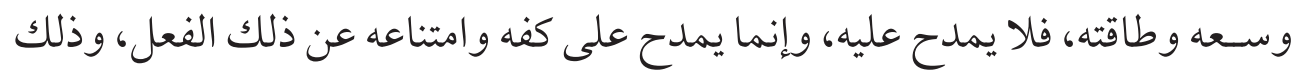

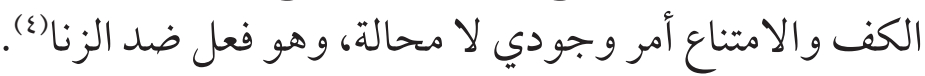

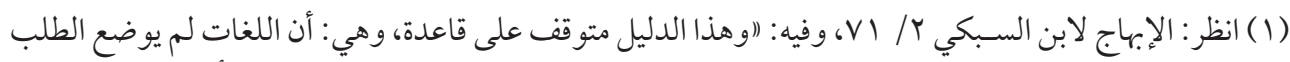

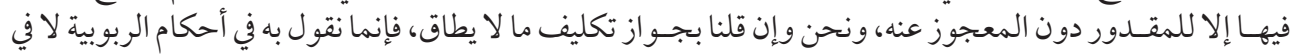

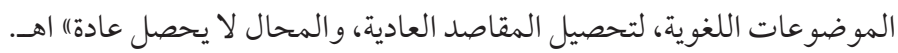

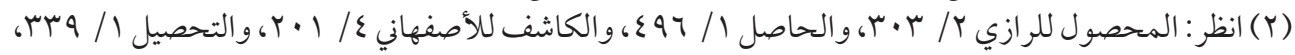

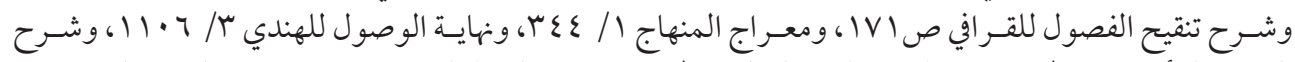

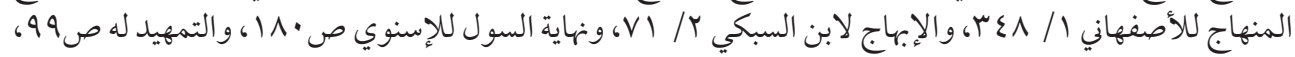

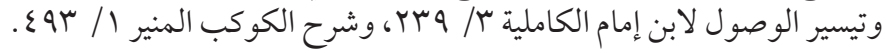

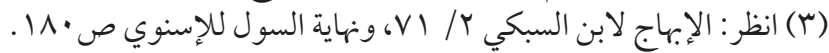

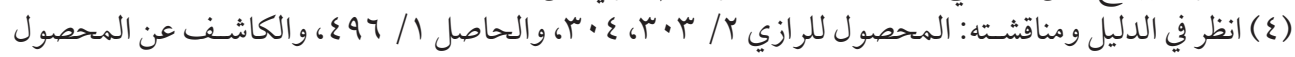

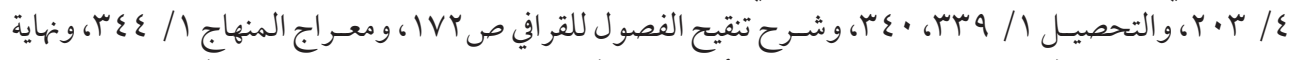

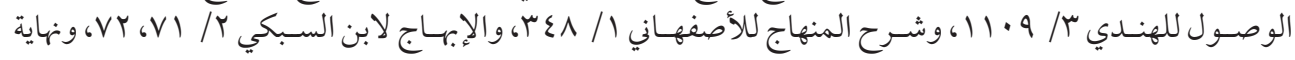

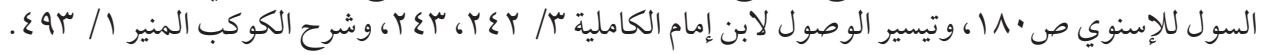


فإن قيل: كما يمكنه فعل الزنا فيمكنه البقاء على العدم الأصلي ولا يغيره، وعدم تغييره

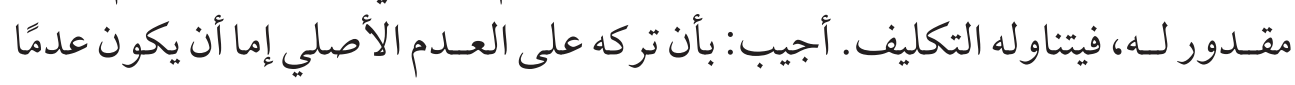

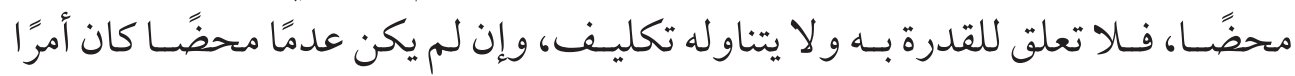

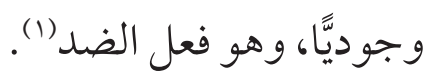

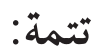

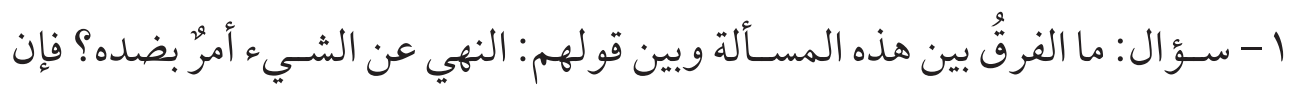

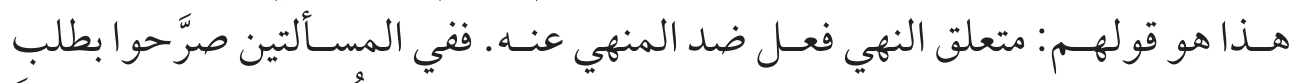

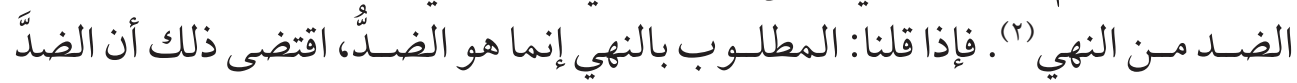

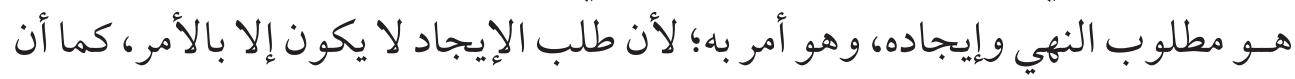
طلب الإعدام لا يكون إلا بالنهي، ففي الصورتين الضد مأمور به (rاد.).

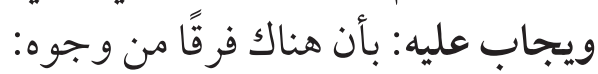

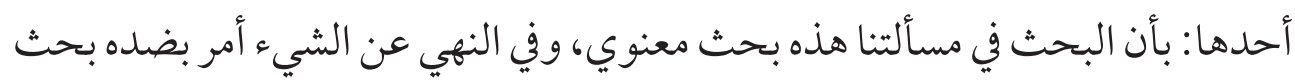

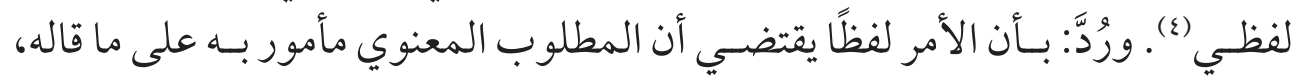
فيحصل الاشتباه (0)

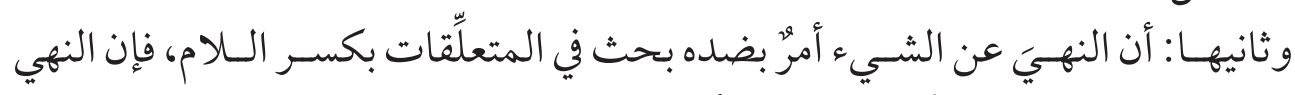

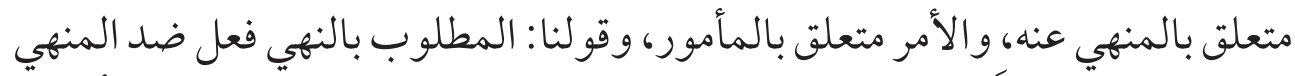

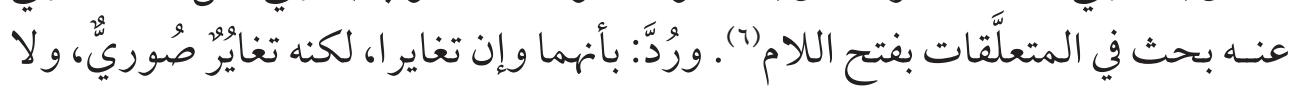
يلزم منه عدمّ تداخل إحدى المسألتين في الأخرى (v).

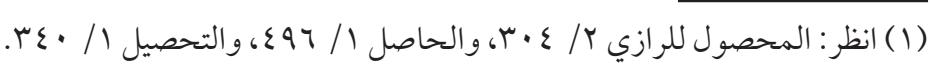

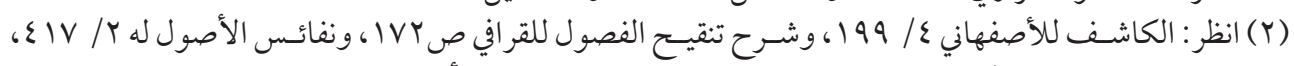

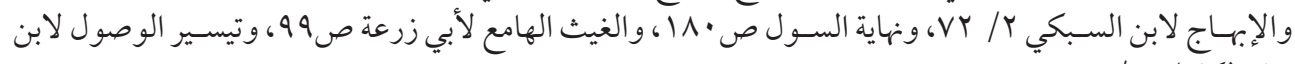

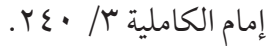

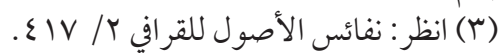

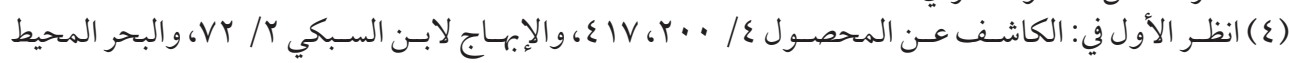

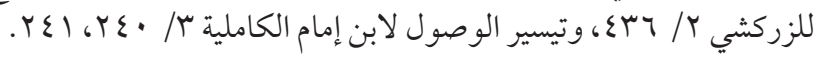

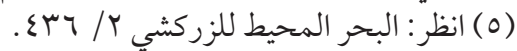

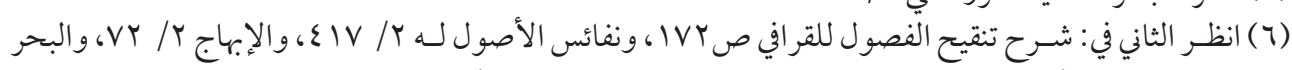

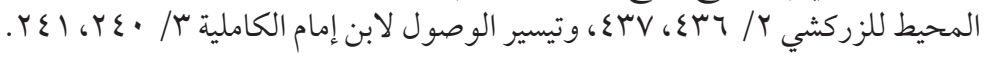

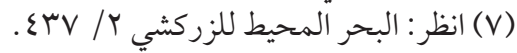


وثالثها: أن البحث في تلك المسـألة في دلالة الالتزام على ضد المنهي عنه، نقول: متى الثى

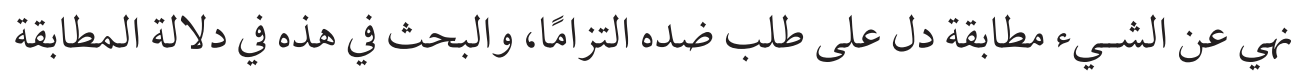
ما مدلو لها المطابقي، هل هو العدم الذي سمعه السامع في قوله: "لا تتحرك"، أو ضده الذي لا يسمعه السامع وهو السكون؟ و الفرق بين دلالة المطابقة والالتزام ظاهر (1).

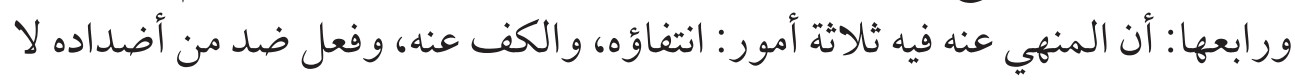

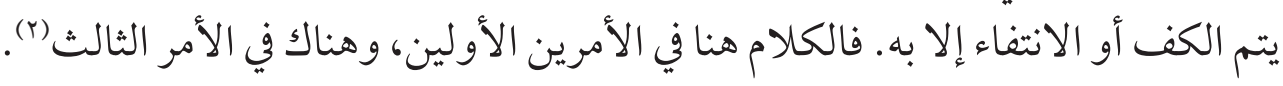

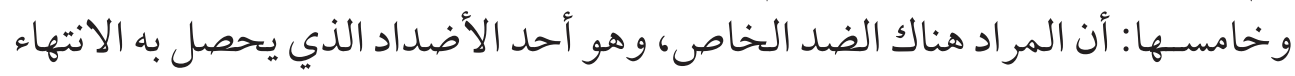

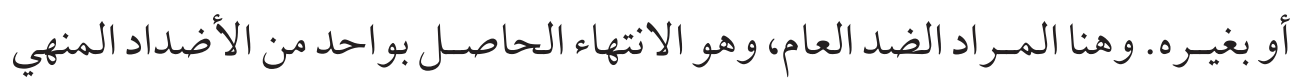

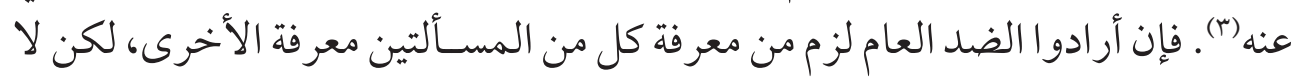

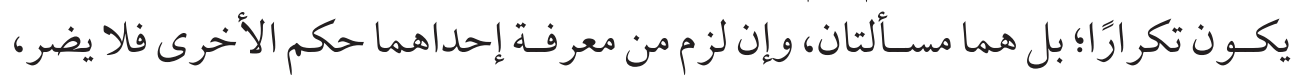

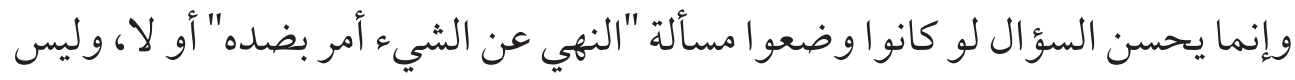

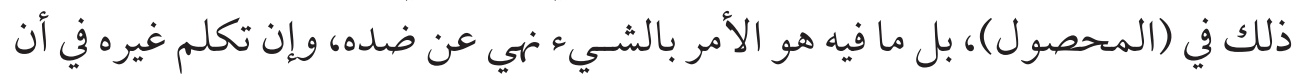

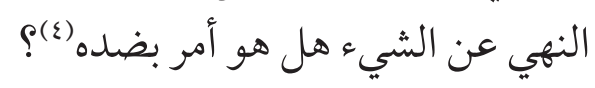

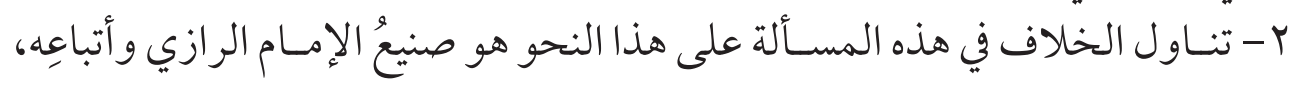

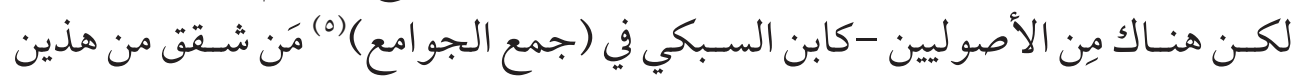

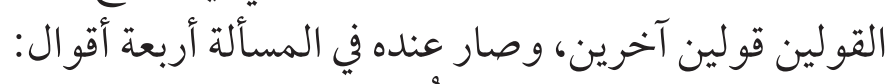

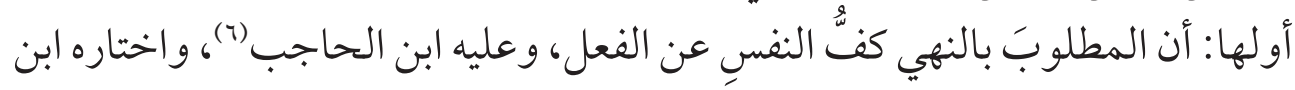

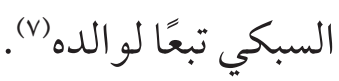

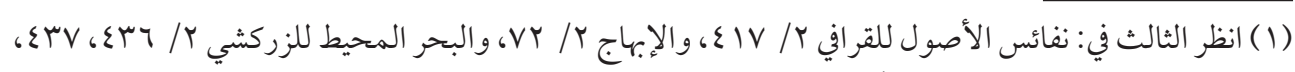

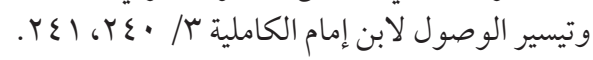

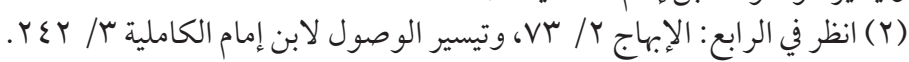

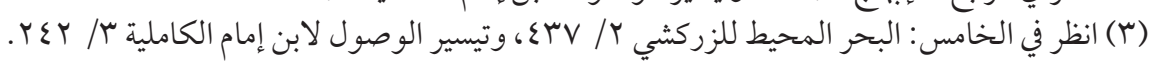

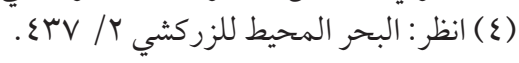

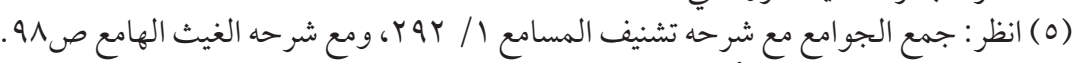

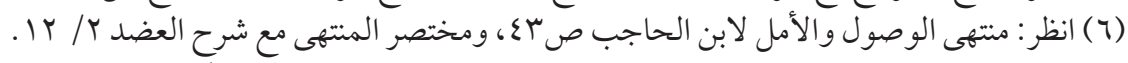

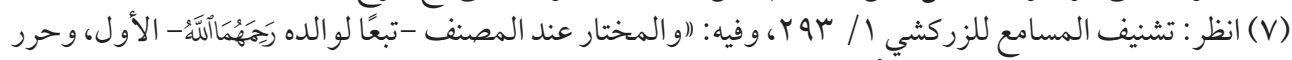

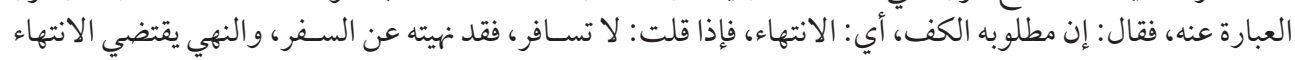

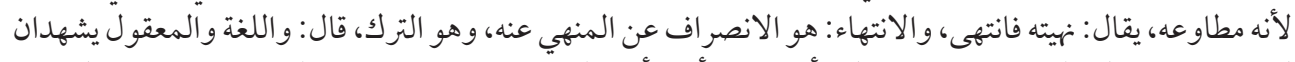

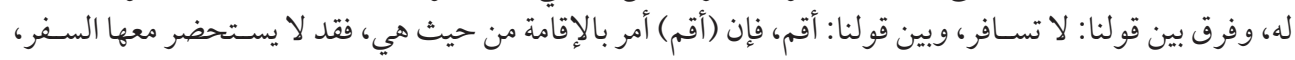




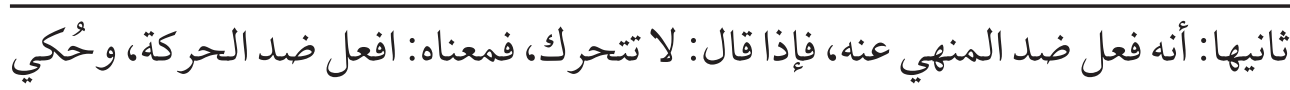

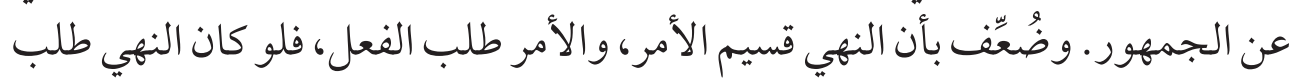

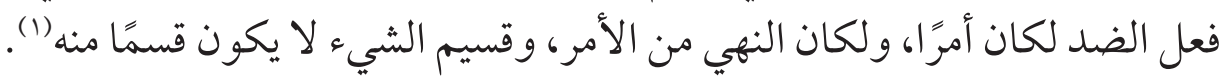

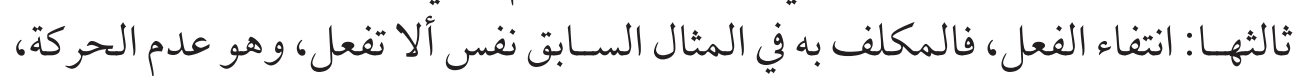

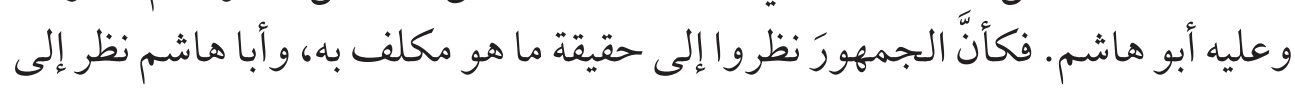

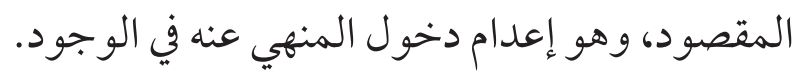

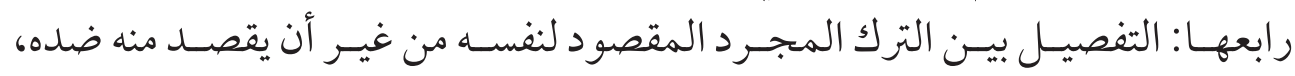
فالتكليـف فيـه بالفعل -كالصوم، فالكف فيه مقصو د، ولذلـك و وجبت فيه النية- وبين

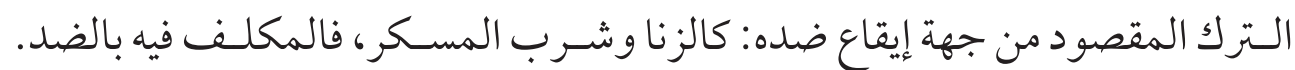
وهذا التفصيل ظاهر كلام الغزالي (r) في (المستصفى) (r).

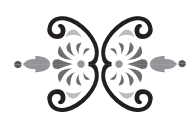

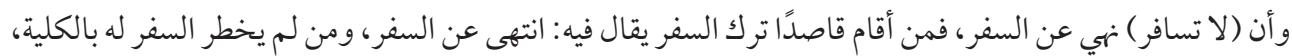

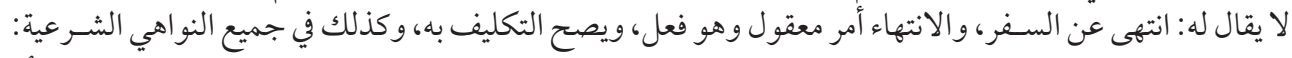

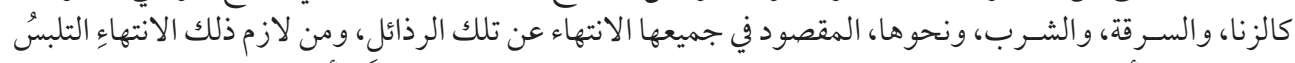

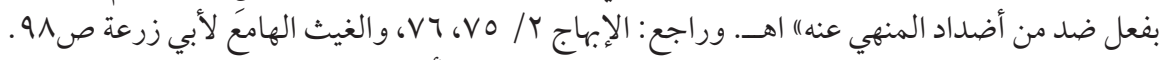

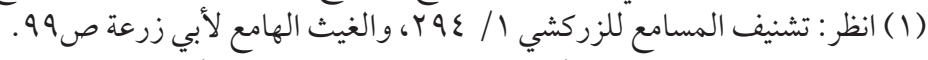

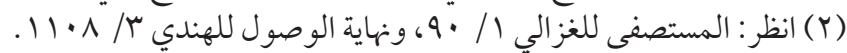

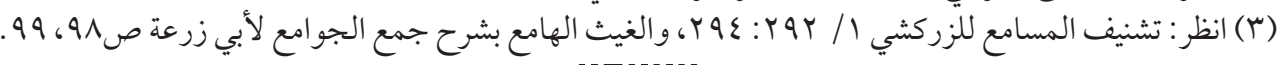




\section{المسألة العاشرة: النهي عن متعدد(1)}

النهـي إن كان عـن شـيء و احد فهـو ظاهر لا كلام فيـه، و إن كان عن متعـدد فهو على لى

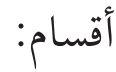
الأول (r): أن يكون النهي عن الجمع بين أشـياء، أي: الهيئة الاجتماعية دون المفردات

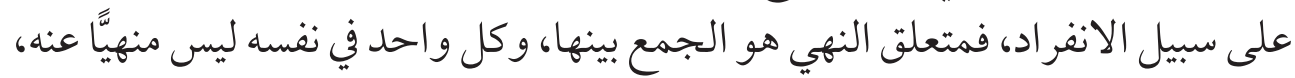

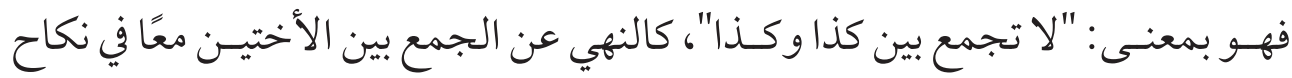

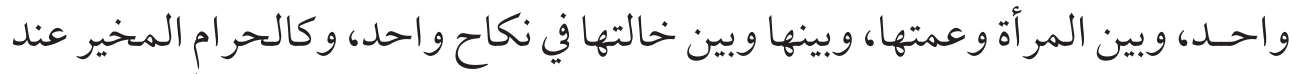

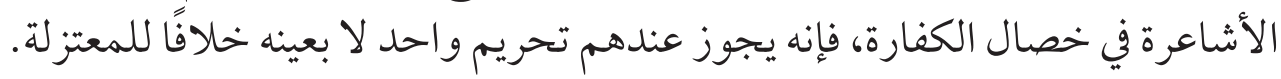

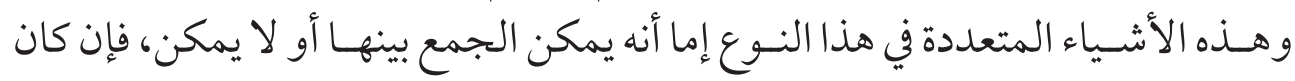

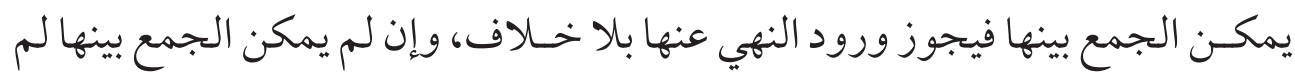

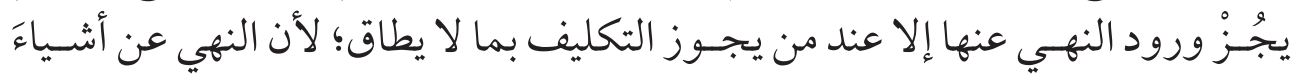

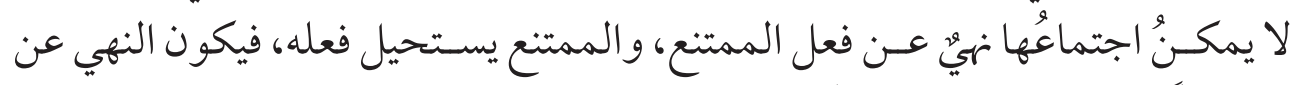

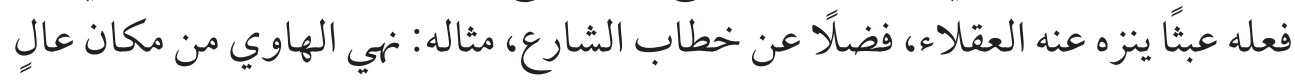
شاهق عن الاستقرار في الهو اء.

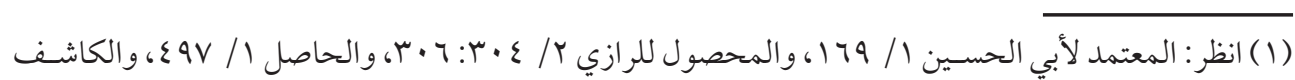

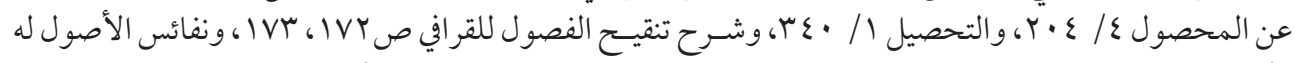

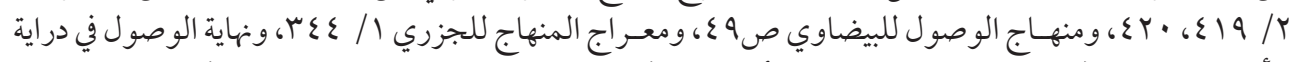

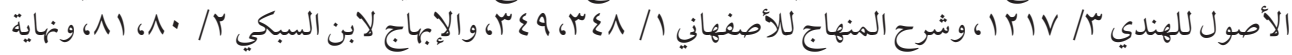

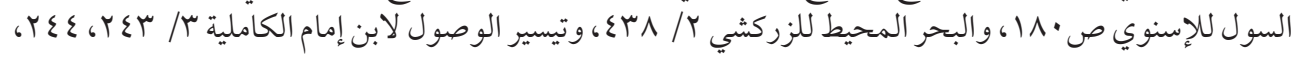

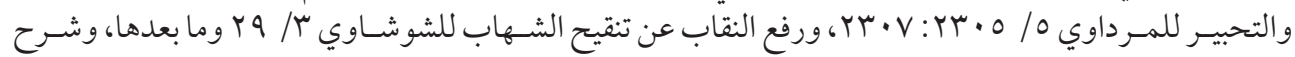

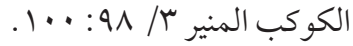

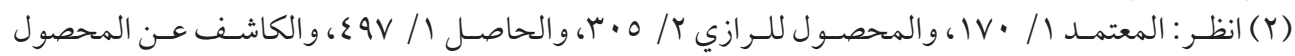

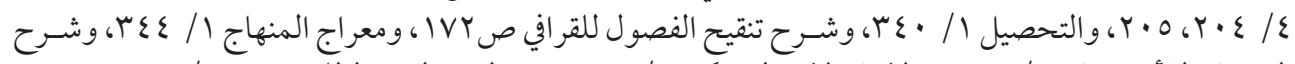

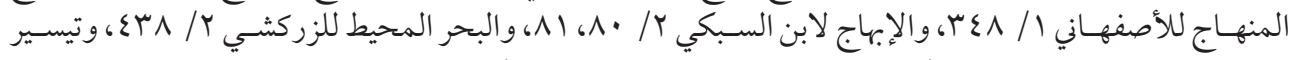

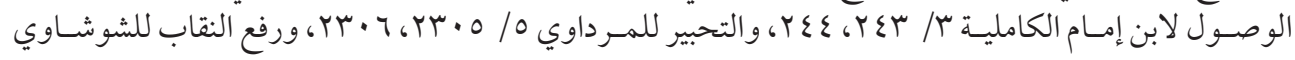

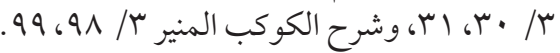


الثاني (1): عكس الأول، وهو النهي عن الافتراق دون الجمع، كالنهي عن الاقتصار على

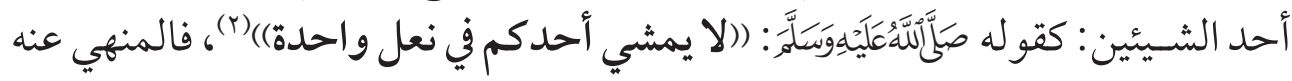

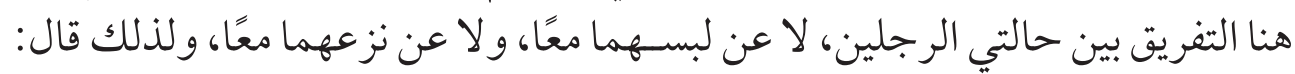

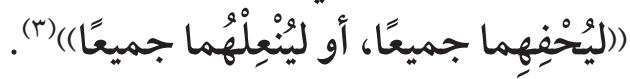

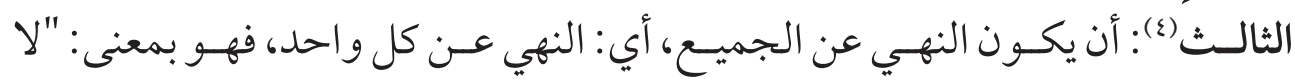

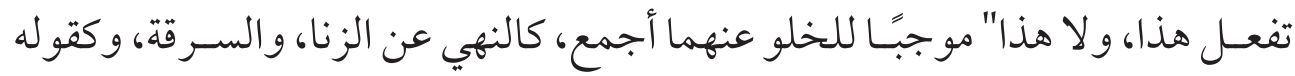

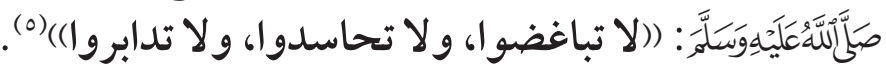

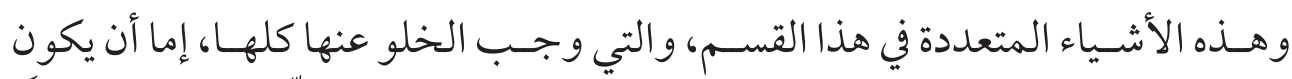

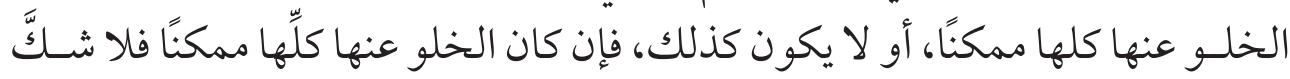

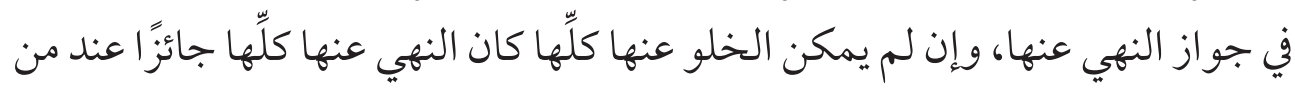
يجوز التكليف بما لا يطاق.

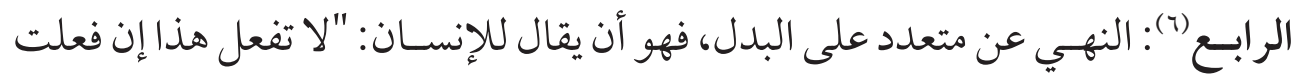

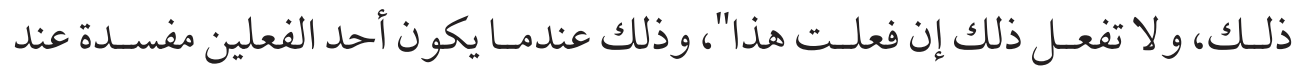

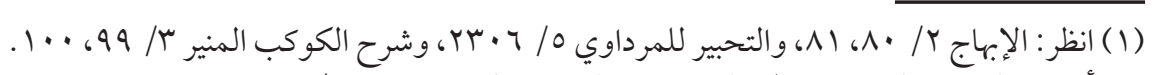

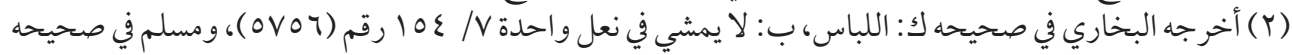

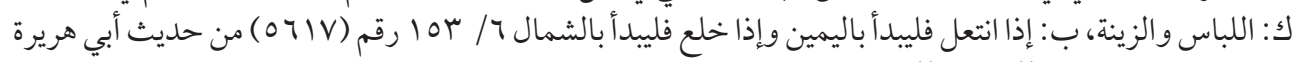

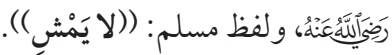

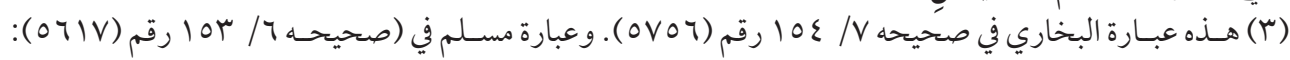

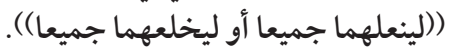

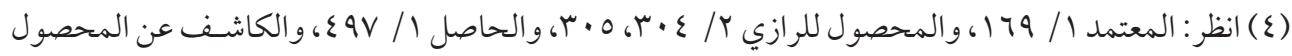

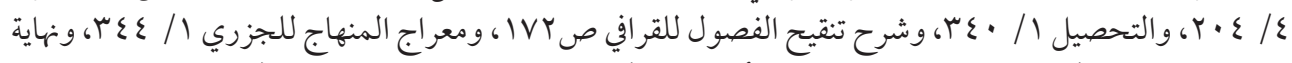

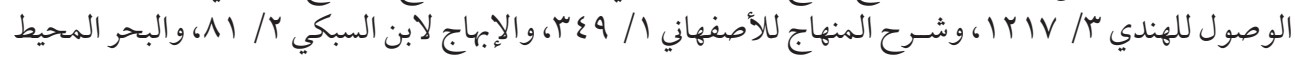

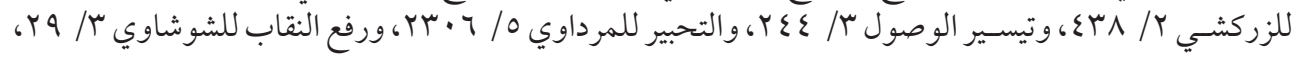

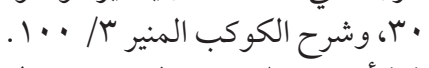

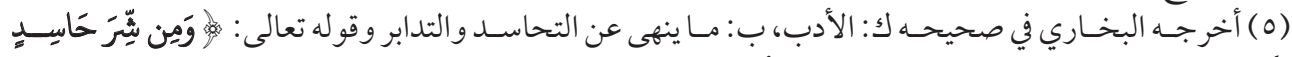

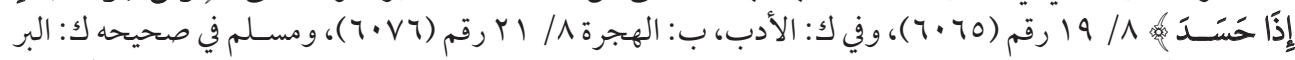

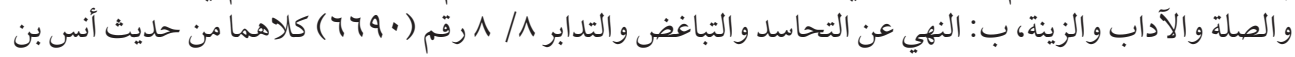

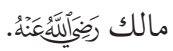

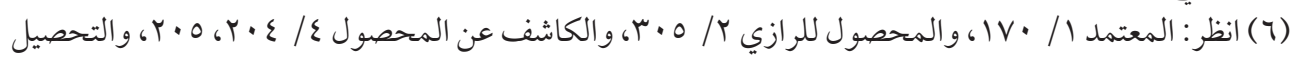

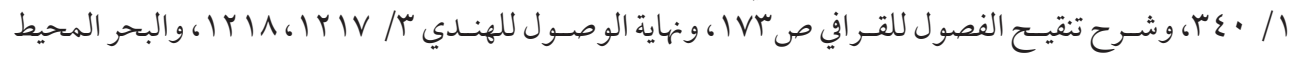

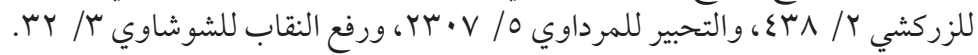

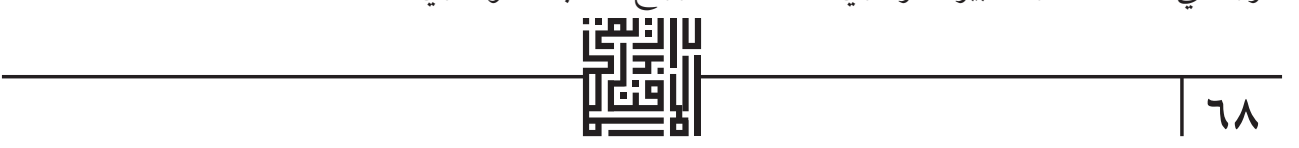




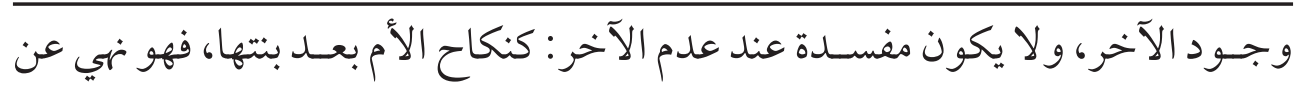

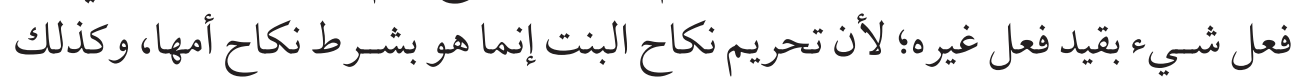

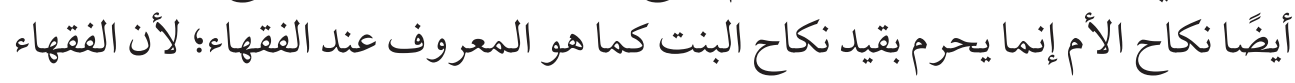

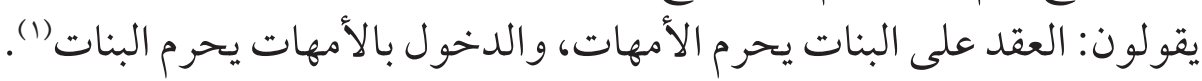

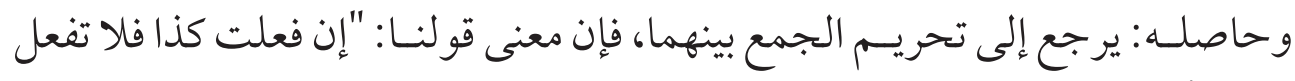
ذلك" أن الجمع بينها محرم. الخامس (r): النهي عن البدل، وذلك يفهر ملكم منه شيئان:

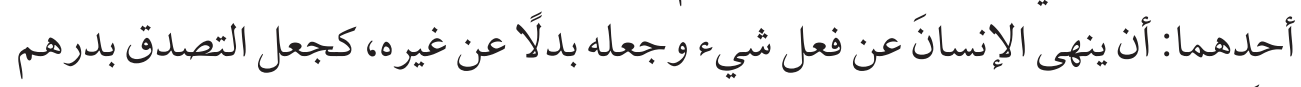

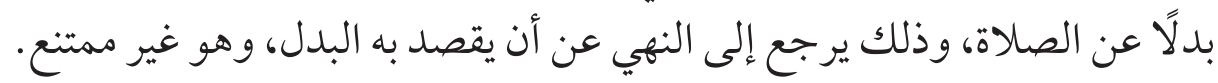

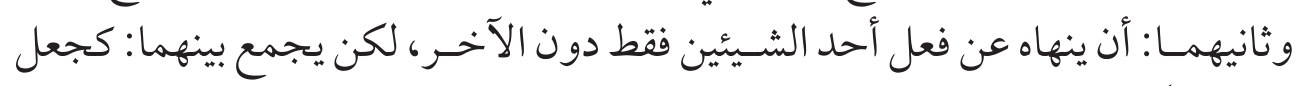

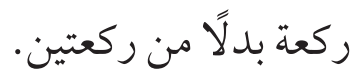

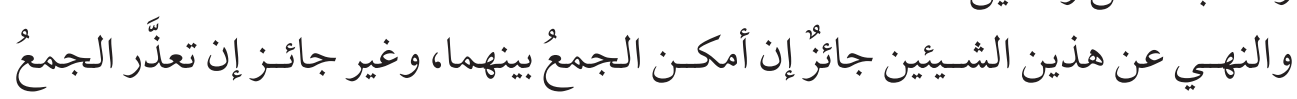
على قول مَن لا يجوز التكليف بما لا لا يطاق.

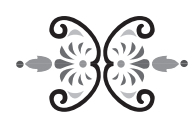

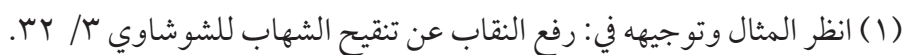

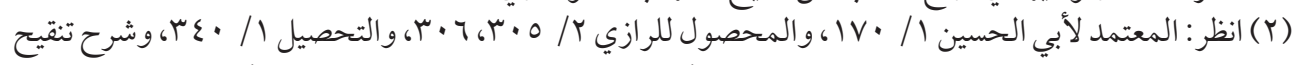

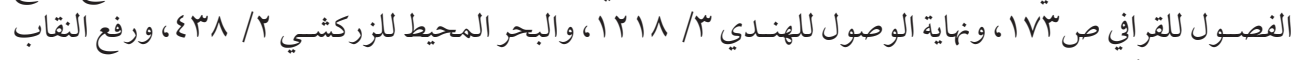

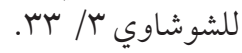




\section{المسألة الحادية عشرة: \\ النهي عن الشيء هل هو أمر بضلهه(1)}

الشيء المنهي عنه إما أن يكون له ضد و احد، أو يكون له أكثر من ضد، فإن كان له ضد

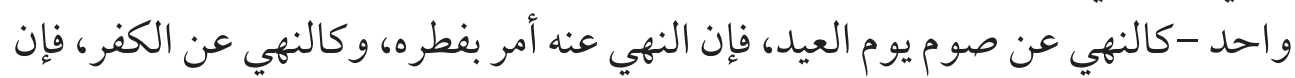

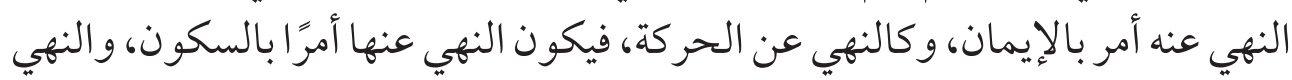

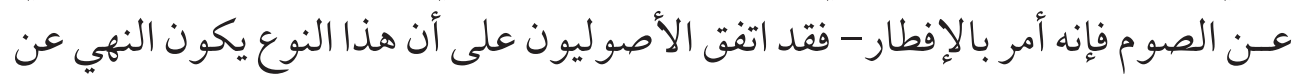

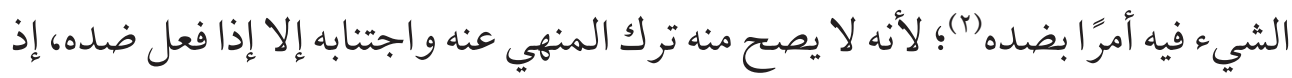

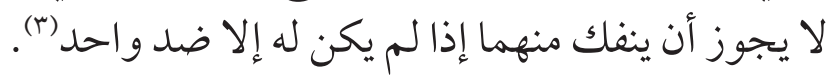

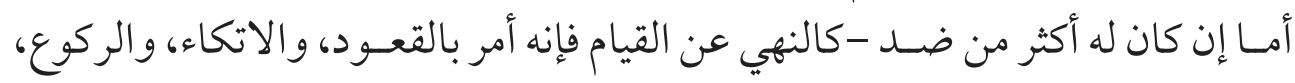
و السجود، والاضطجاع- فقد اختلف فيه الأصوليون على أقوال، هي: فئ فئه

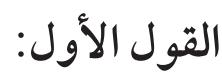
أن النهي عن الشيء أمر بأضداده كلها. وعليه بعض الحنفية، وبعض أهل الحديث الهيث (ع).

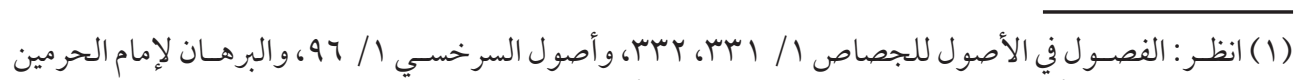

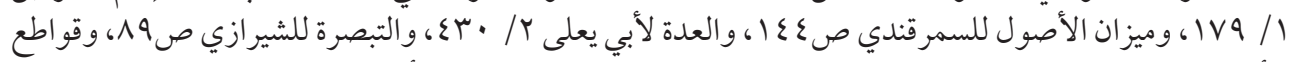

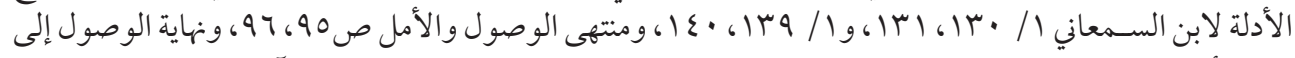

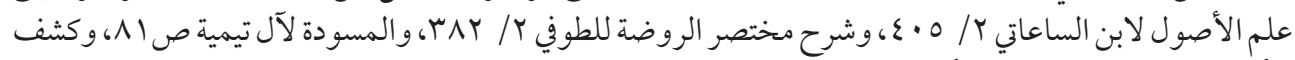

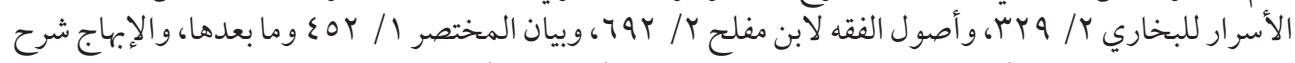

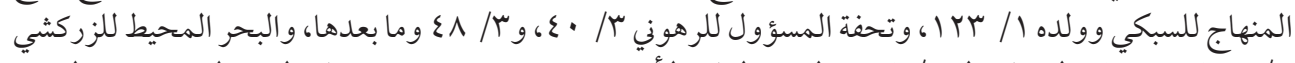

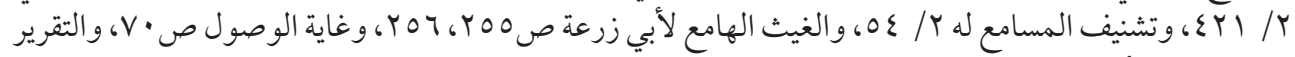

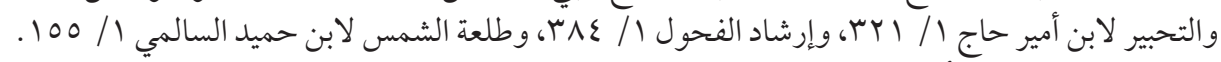

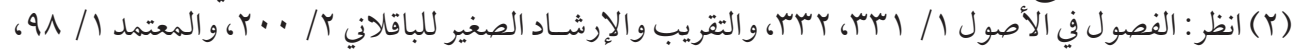

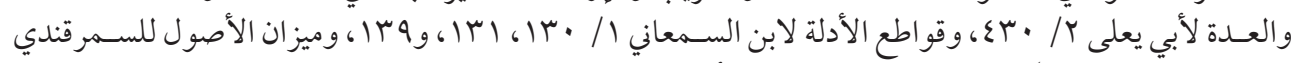

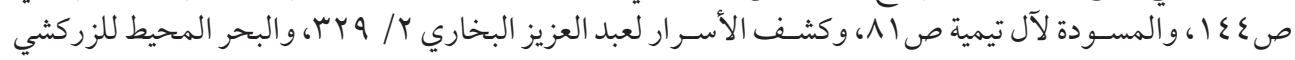
r

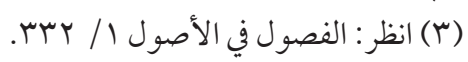

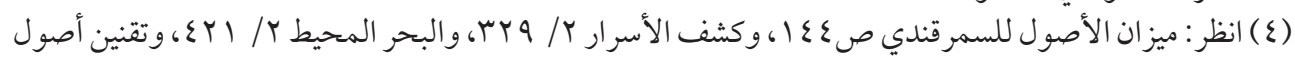

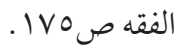


وممن اختاره: إمام الحرمين في (الورقات)(1)، و الشيرازي في (التبصرة) قال: من طريت

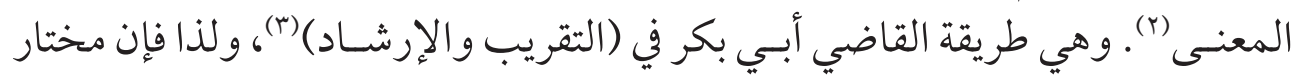

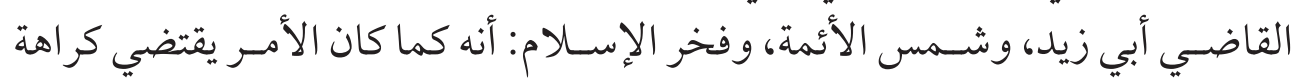

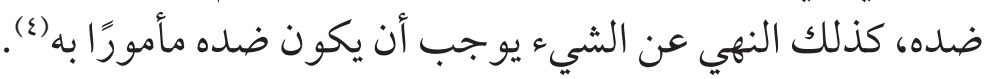

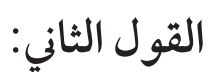

أن النهي عن الشيء أمر بأحد أضداده المنهي عنها، وإن كان هذا الو احد غير معين (0).

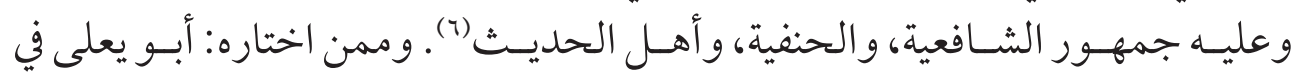

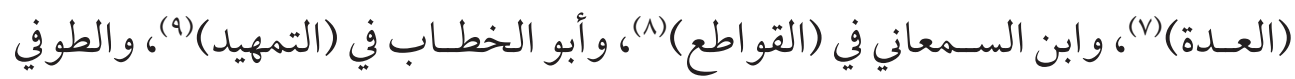

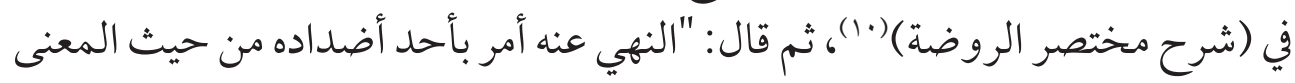

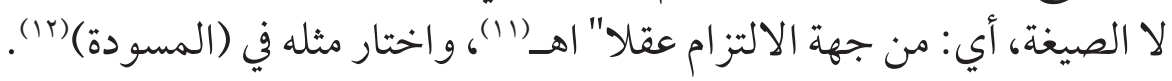

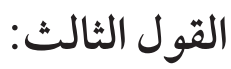
أن النهي عن الشيء ليس أمرًا بضده مطلقًا (rا).

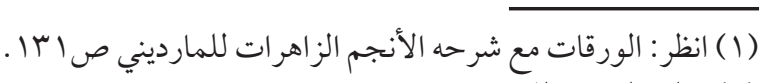

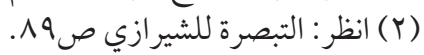

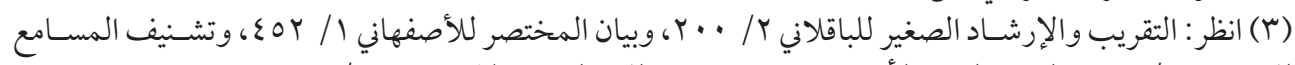

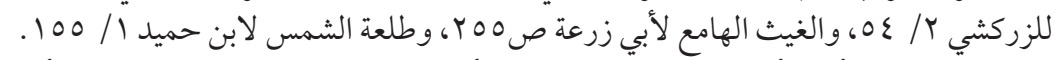

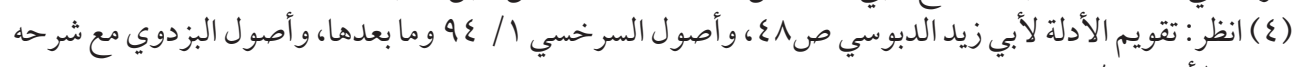

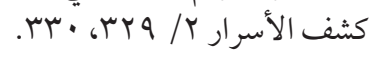

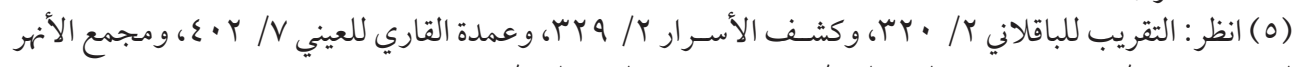

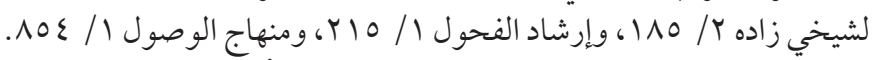

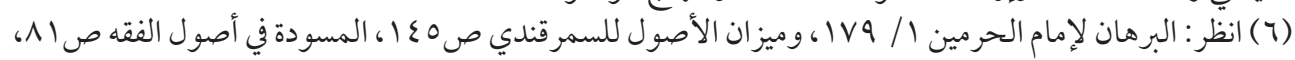

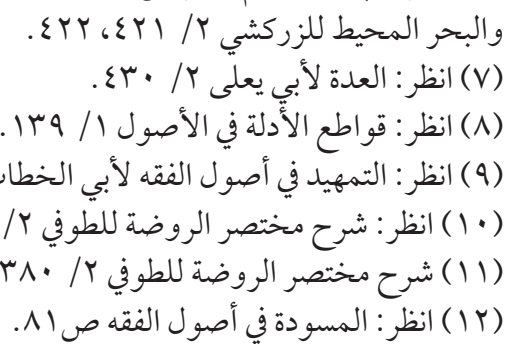

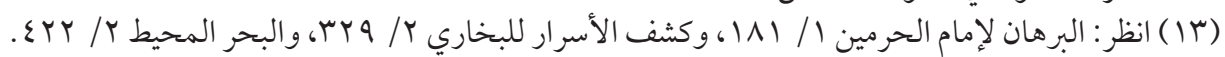




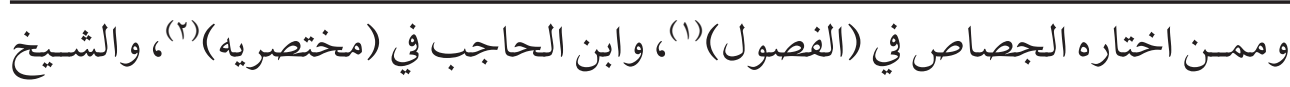

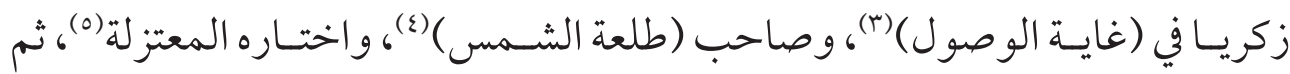

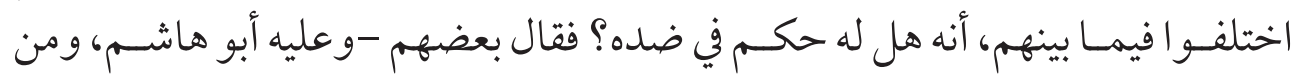

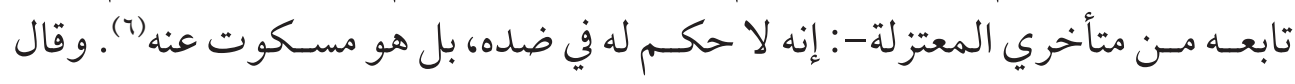

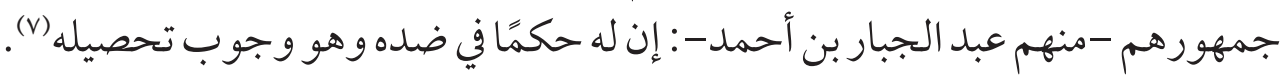

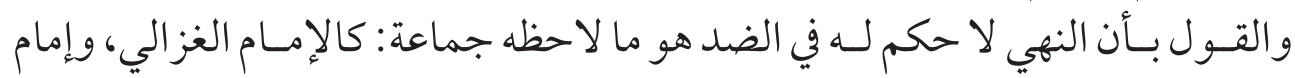

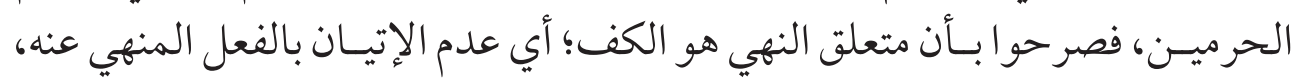

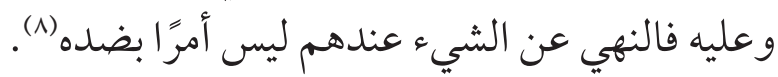

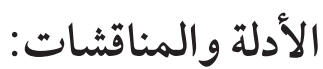

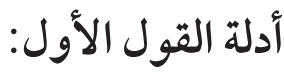

استدلو اعلى أن النهي عن الشيء أمر بأضداده كلها بأدلة، منها:

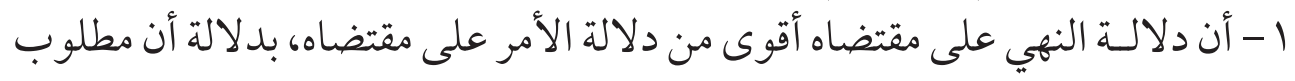
النهي فعل الضد، فاستحضار الضد في جانب النهي أولى منه في جانب الأمر؛ لأنه في

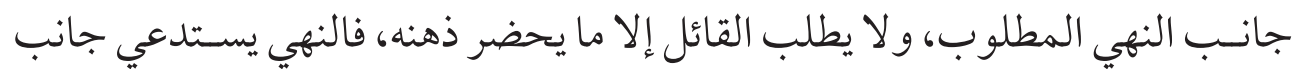

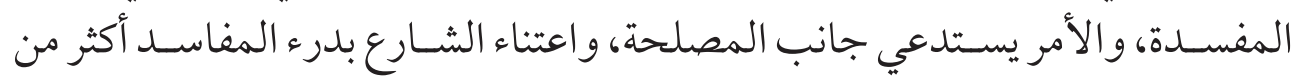
اعتنائه بجلب المصالح (9).

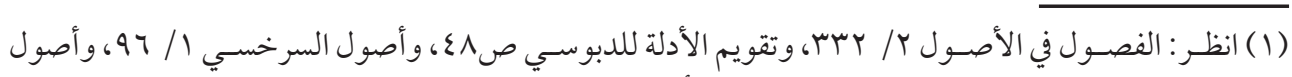

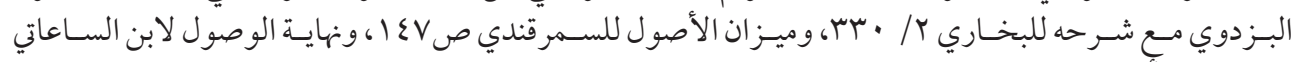

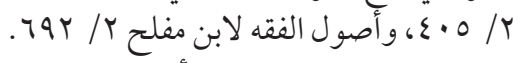

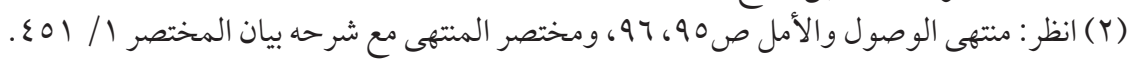

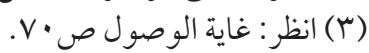

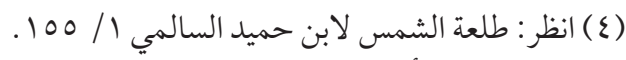

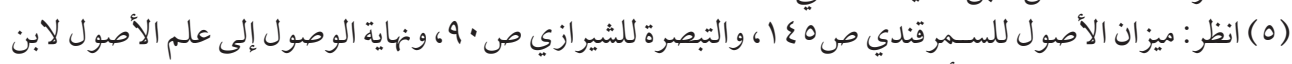

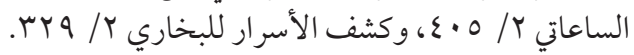

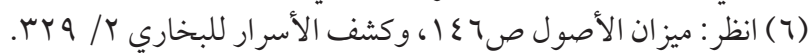

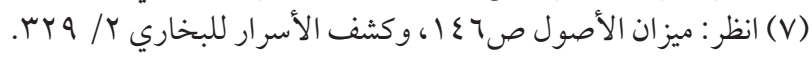

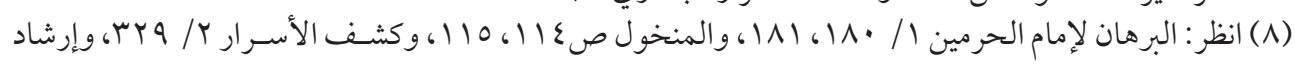

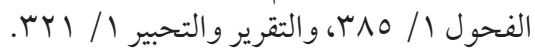

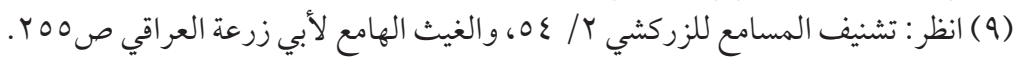




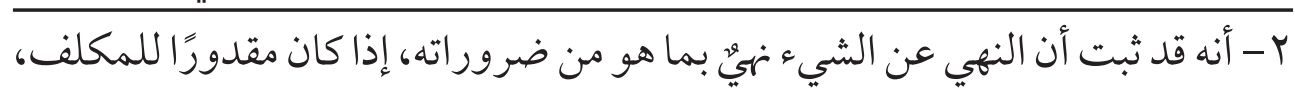

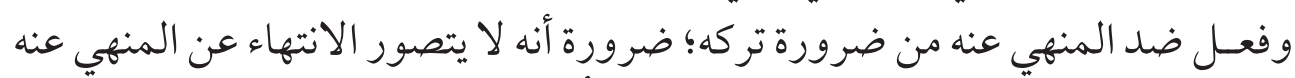

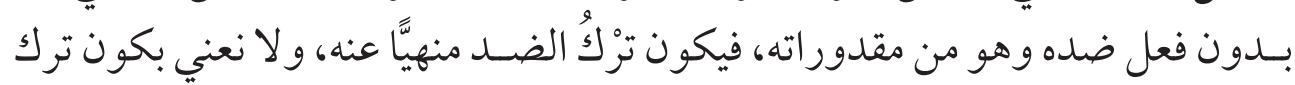

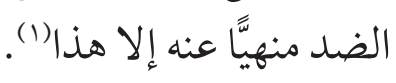

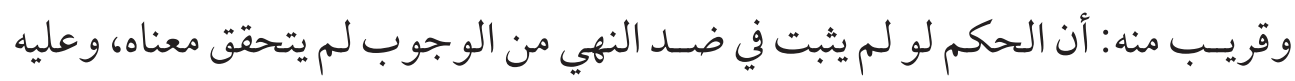

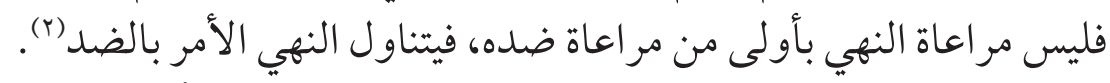

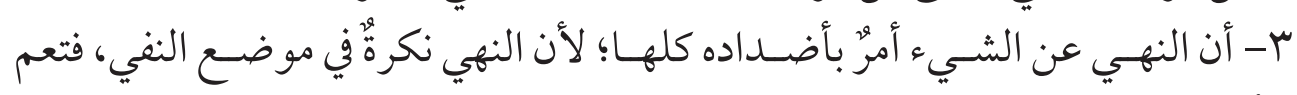

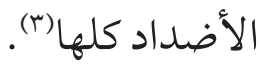
ع - أن لفظ النهي يصحُّ ورودُه مقترنًا بذكر إباحة جميع أضداده، و وعلى ذلك فلا يجوز نفيه ونفي ما اقترن به، فإذا كان اللفظ للنهي عن شـيء فإنه يبقى على على الأمر في غيره مما

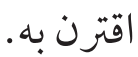

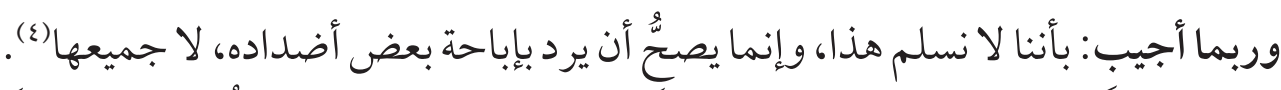

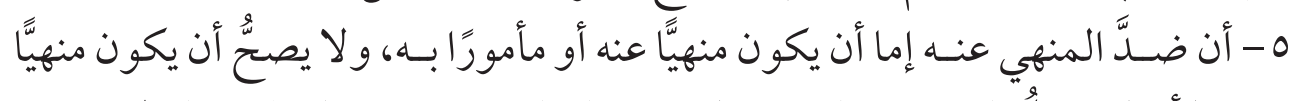

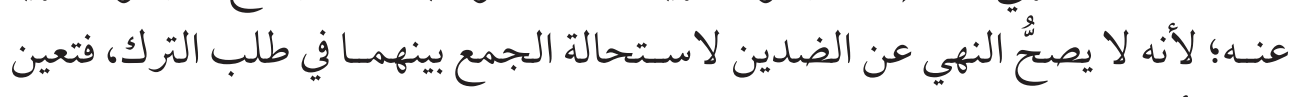

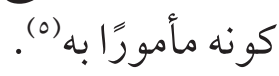

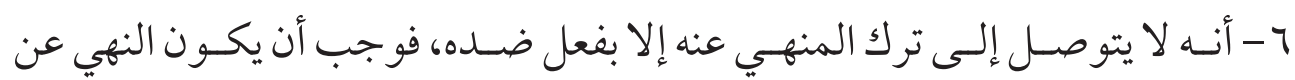

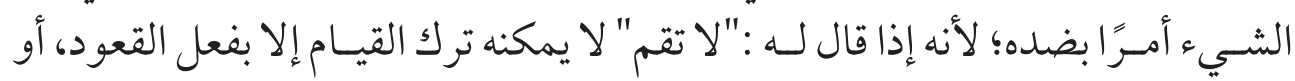

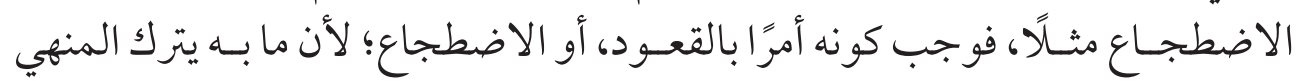

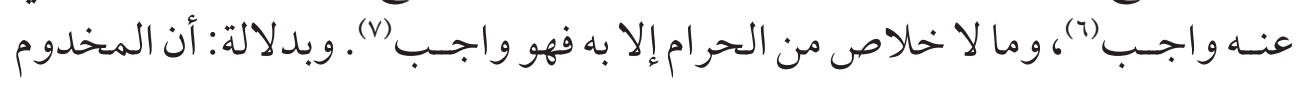
إذ قال لخادمه: "لا تقمى" فقام الخادم، حسـن توبيخه ولومه على اجلى القيام، فيقول له: "لم

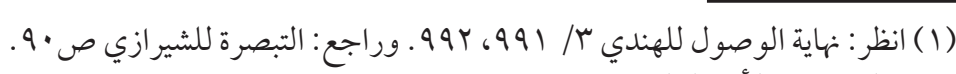

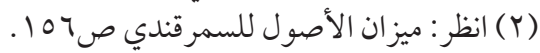

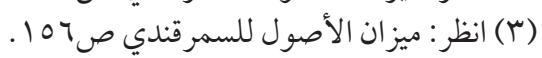

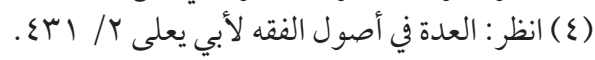

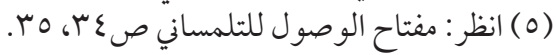

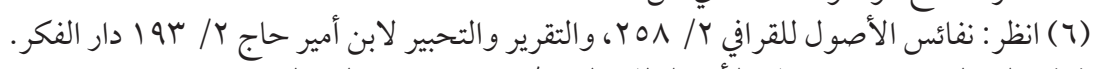

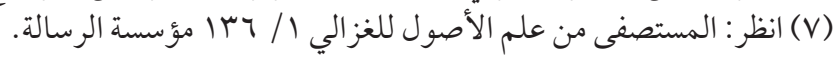


قمــتج"، ولو لـم يكن النهي عن القيـام مقتضيًا للأمر بضده لما حسـن توبيخه ولو مه على القعود (1)

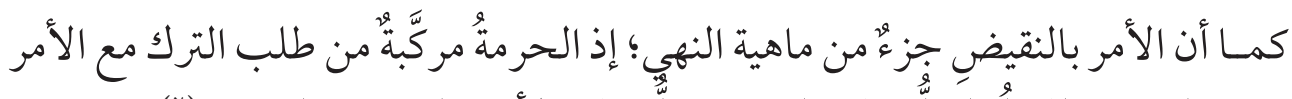

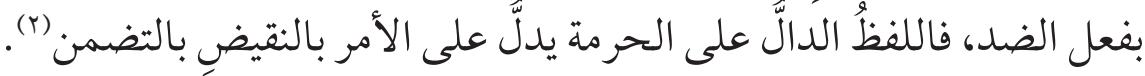
V- أن النهـي طلـب تـرك فعل و وتـرك اك الفعل هو بعينـه فعل الضد، فالنهـي طلب فعل الضد، و كل ما هو طلب فعل فهو أمر، فالنهي بعينه يكون أمرًا بضده، وهو الملَّعَىى (r). وأجيب: بأنه لو كان ترك الفعل هو بعينه فعل الضد لكان الزنا واجبًا من حيث هو ترك هو اللو اط، ولكان اللو اط واجبًا من حيث هو ترك الزنا، فيحصل الثواب بهما، بقصده أداء

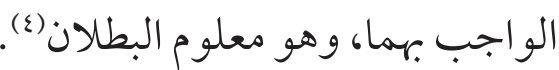

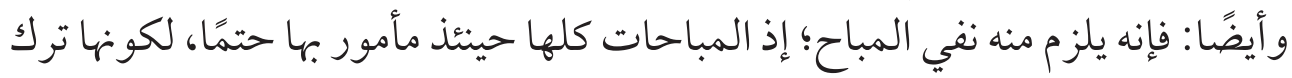

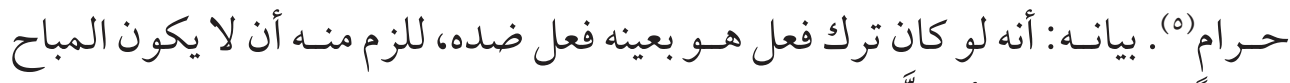

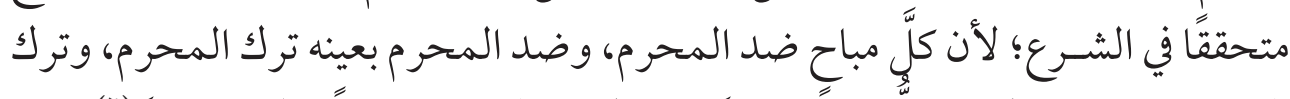
المحرو و اجب، فيكون كلّ مباحً و اجبًا، فلا يكون المباح متحققًا ولا مو جودًا"(7).

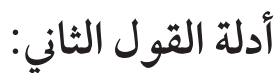
استدلو اعلى أن النهي عن الشيء أمر بأحد أضداده بأدلة، منها:

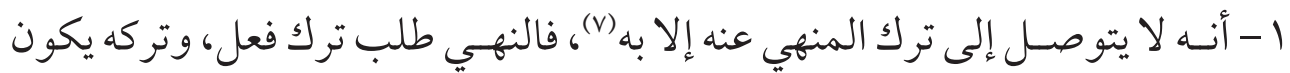

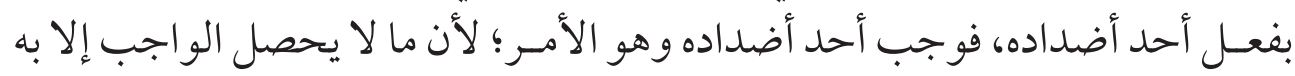
فهو واجب (1)

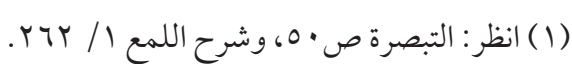

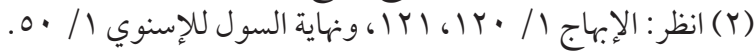

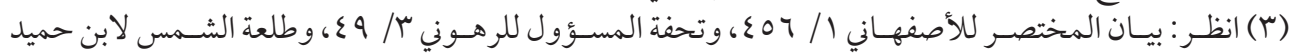

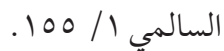

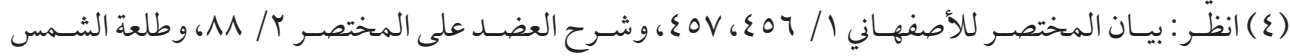
$.100 / 1$

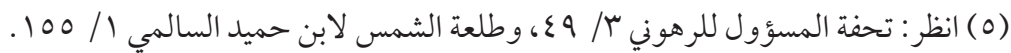

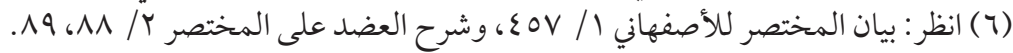

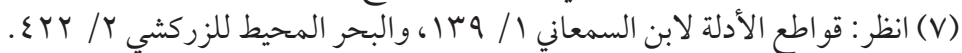

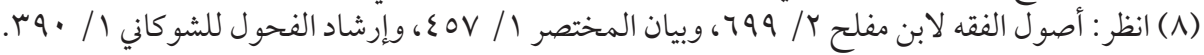




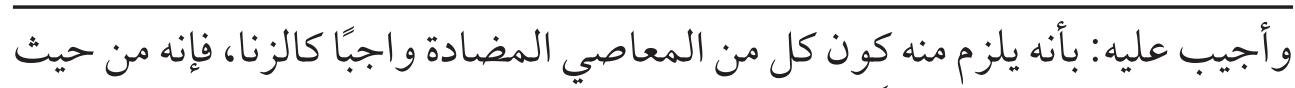

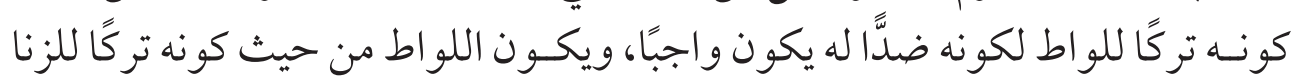

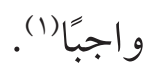

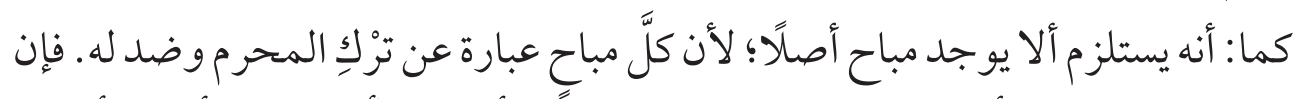

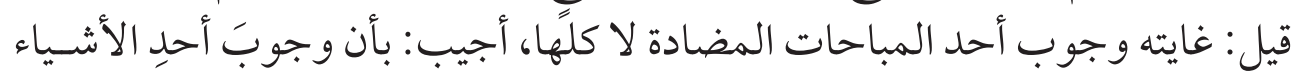

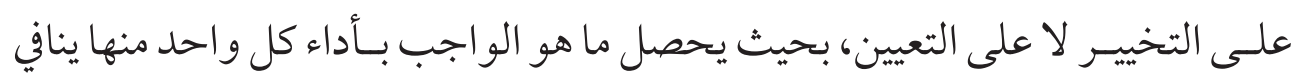
الإباحة، كما في خصال الكفارة) (r).

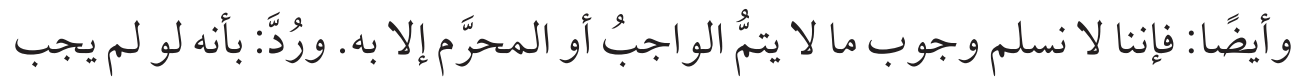

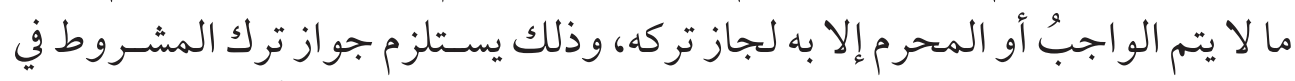

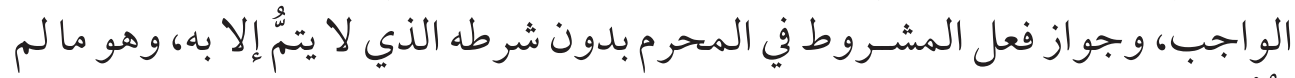

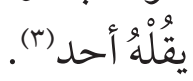

ץ- وقريب من الأول: أنه إذا نهى عن فعل شيء، تضمن ذلك وجوب الكف الكف عنه، و لا الا

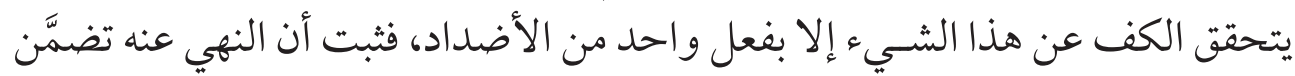

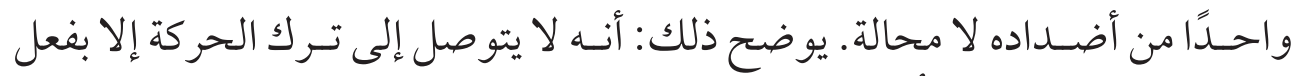

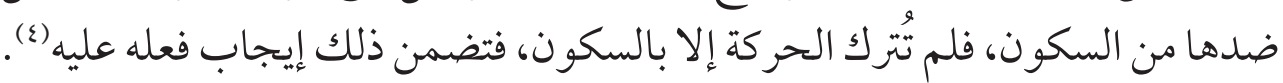

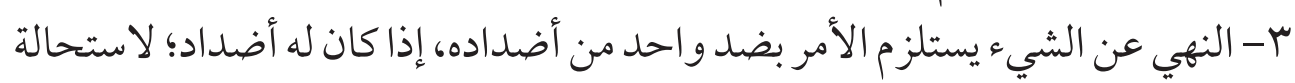

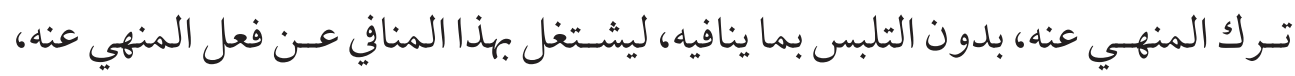

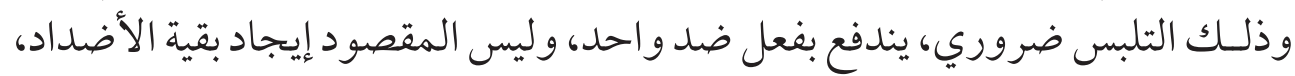

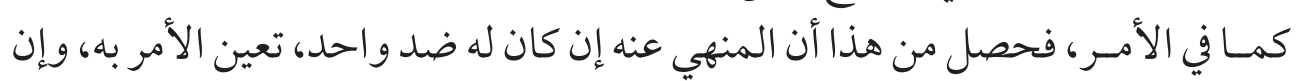

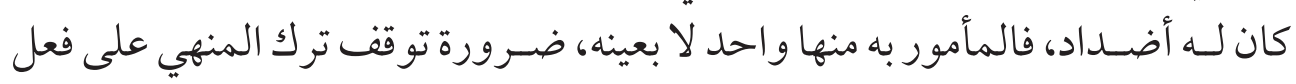
الضد المعين أو المبهم (0) إنهان

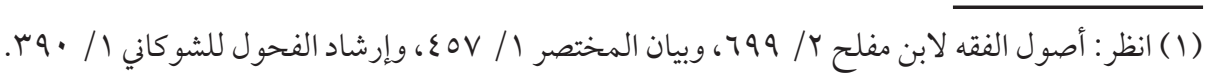

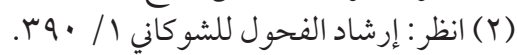

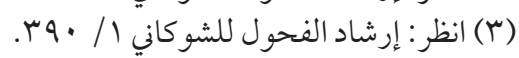

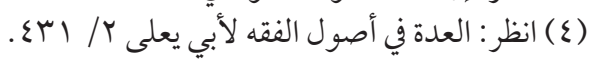

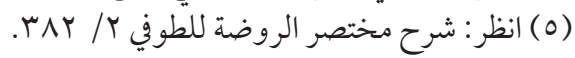




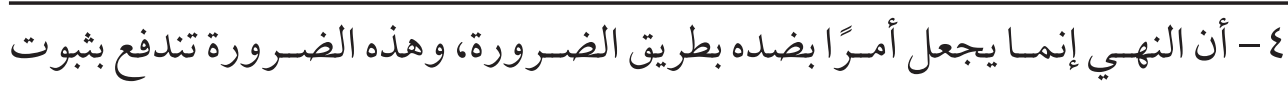

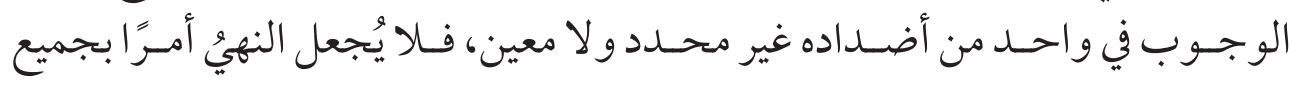

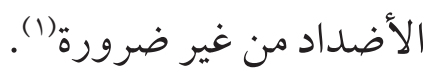

وقد يجاب على هذين الدليلين السابقين: بأن الحكم لو لم يثبت في أضداد النهي كلها

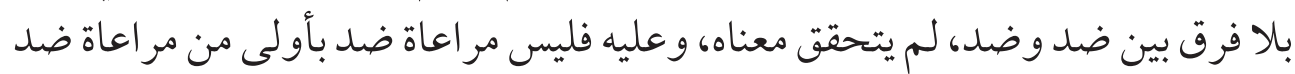

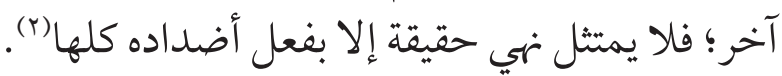

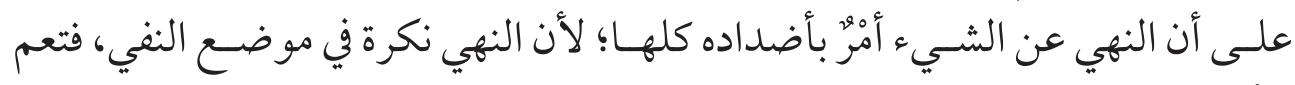

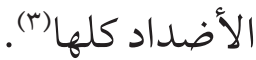

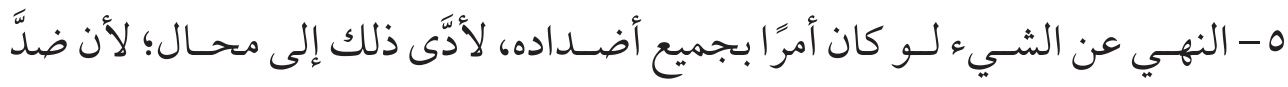

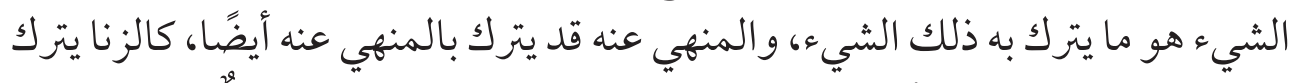

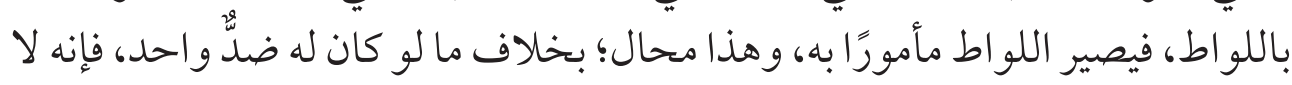

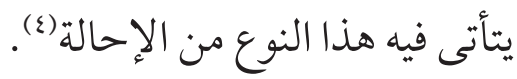

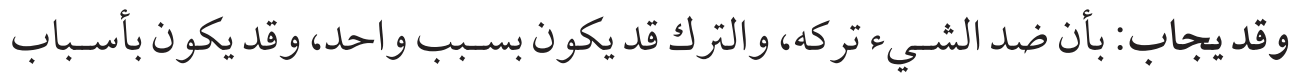

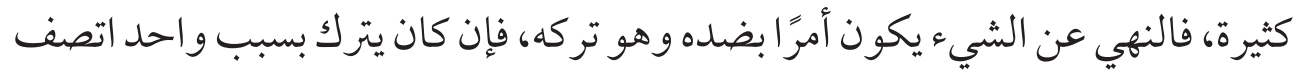

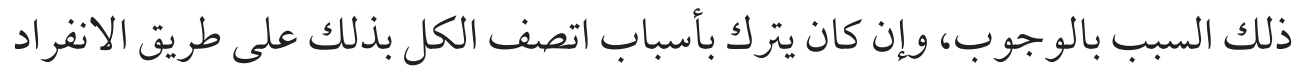
على حسب الحال (0) وما ذكر من الإحالة في جانب النهي، فهو لازمّ لو كان هذا نهيًا مقصودًا عن ضده، وهو

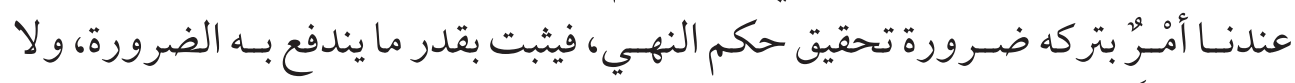
يثبت مطلقًا فيزيد الحكم على العلة، وإنه فاسد (ج).

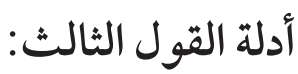
استدلو اعلى أن النهي عن الشيء ليس أمرًا بضده مطلقًا بعدة أدلة، منها:

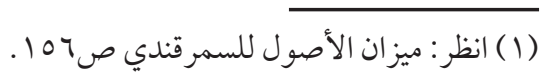

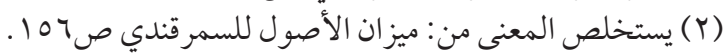

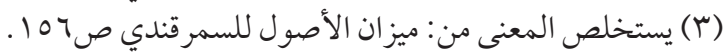

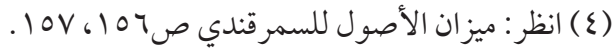

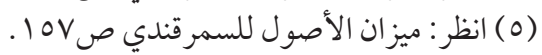

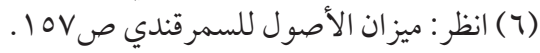




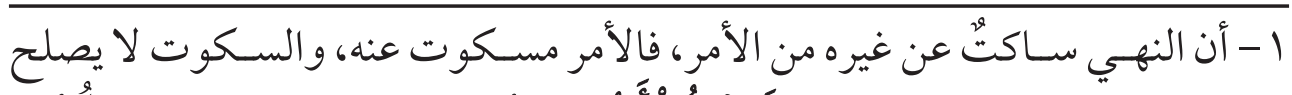

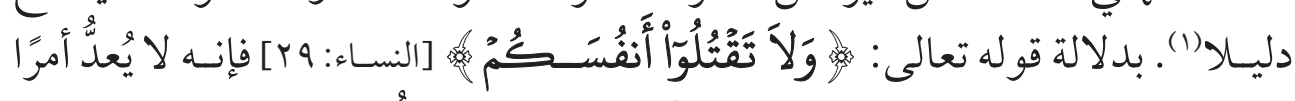

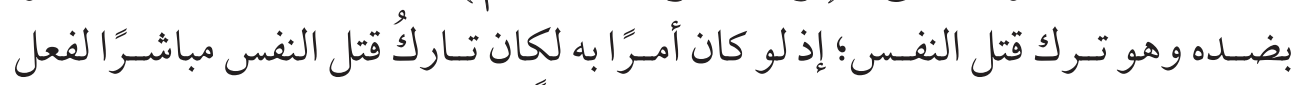

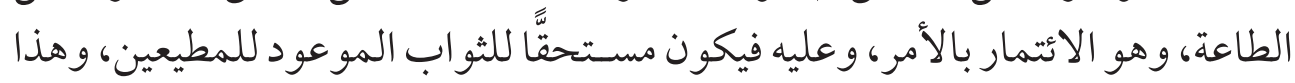
فاسد (r) .

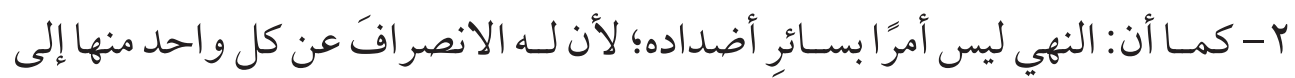

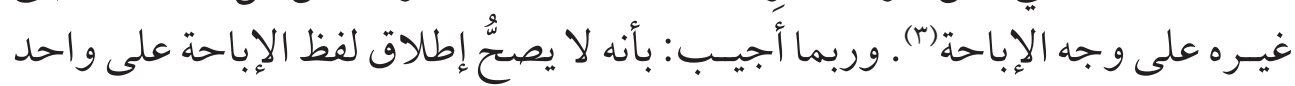

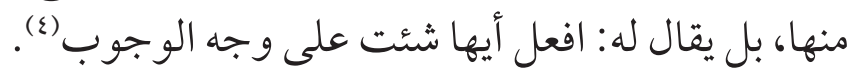

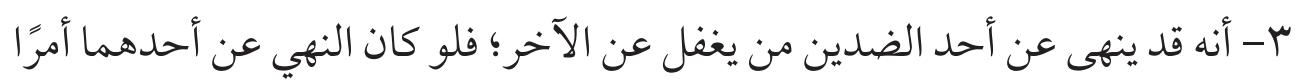

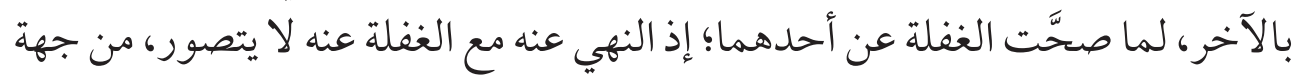
أن النهي يستدعي تصور المنهي عنه، ليصح توجه القصد إليه، لتعلق النهي به (0).

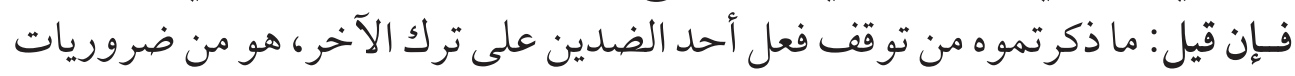

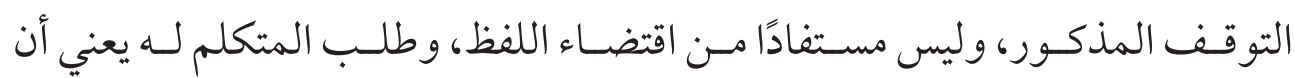

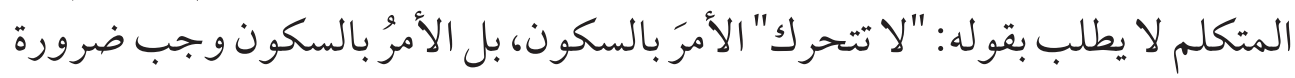

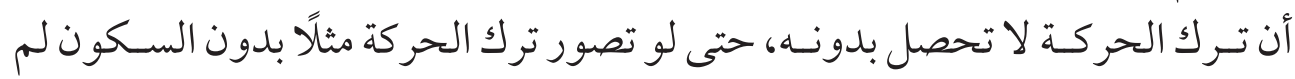
يكن منهيًّا عنه.

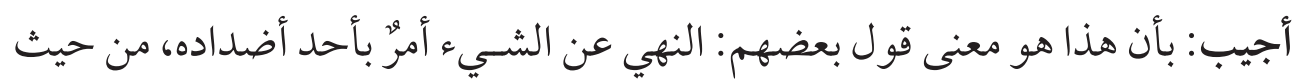

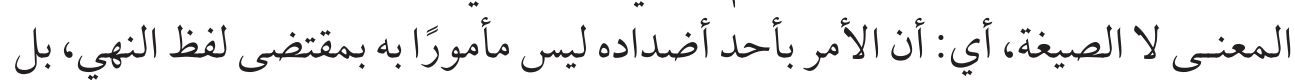
لضرورة توقف امتثال نهيه عليه، و استحالة ترك الشيء بدون فعل واحد الهد من أضد أضداده (7).

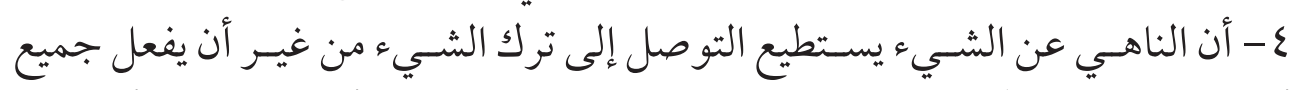

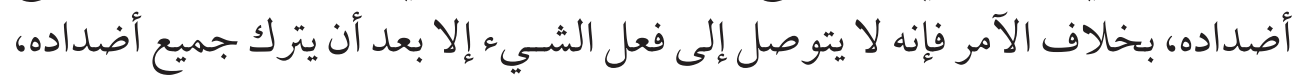

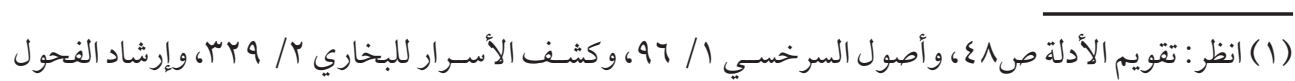

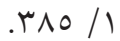

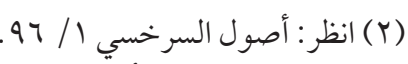

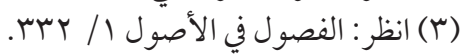

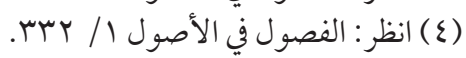

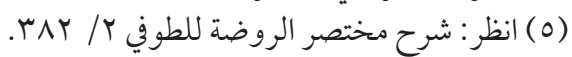

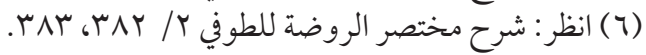


فافترقـا لهذا المعنى، و عليه فإذا كان يسـتطيع التو صل للـترك دون أن يفعل، فلا يكون

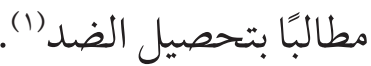

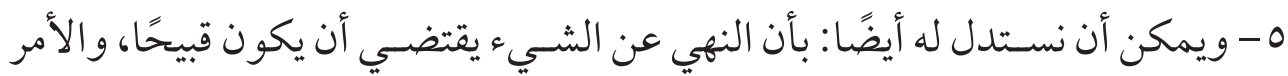

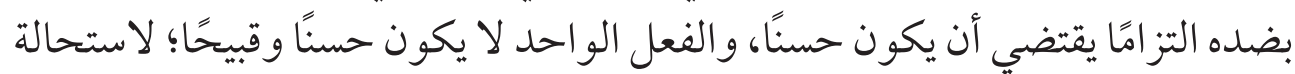

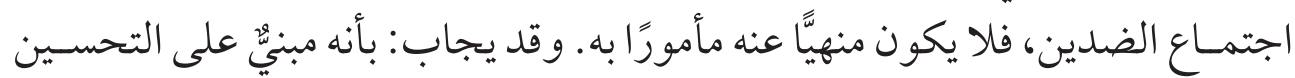

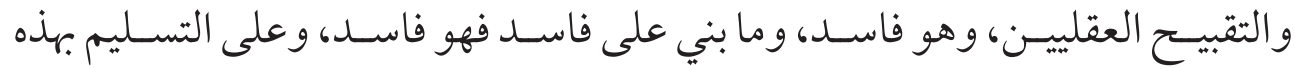

القاعدة فلا استحالة؛ إذ يحتمل أن يحسن الفعل باعتبار، ويقبح باعتبار آخر (r).

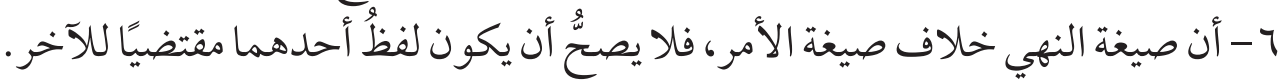

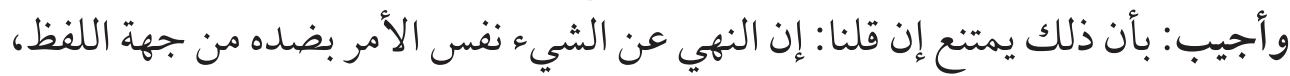

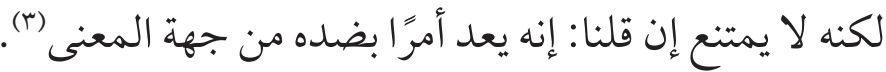

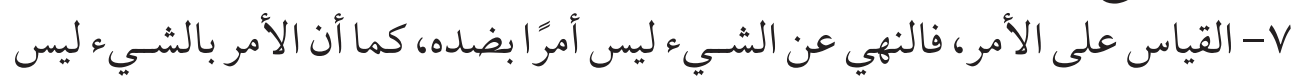
نهيًا عن ضده. و أجيب: بأننا لا نسلم هذا، بل هو أمر بضده، فإن كان له ضد و احد فهو أمر به، وإن كان له أضداد فهو أمر بضد من أضداده، فلا فرق بينهما (ع) .

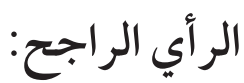
بعد عرْض أقو ال العلماء في المسألة، رأينا أنهم اختلفو اعلى ثلاثة آراء تفصيلًا: بين من

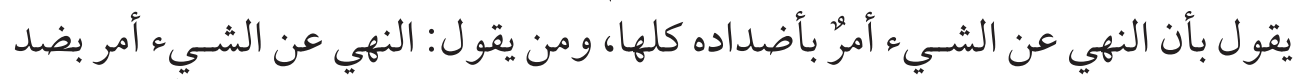

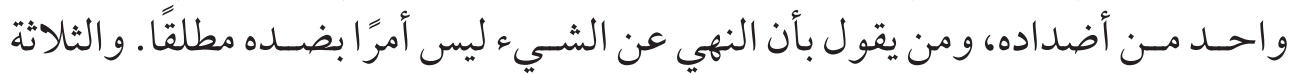

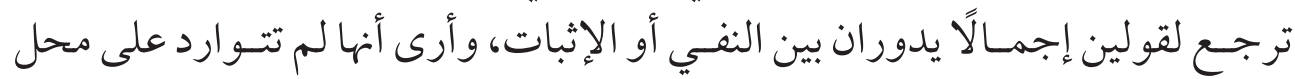

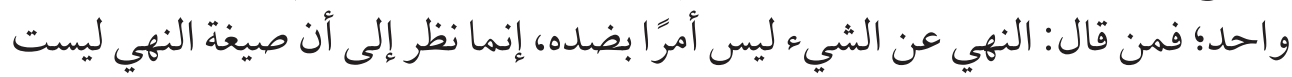

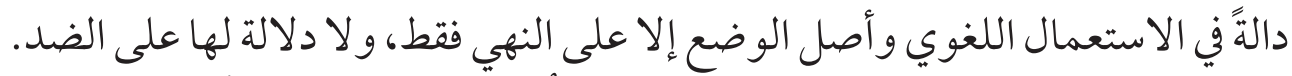

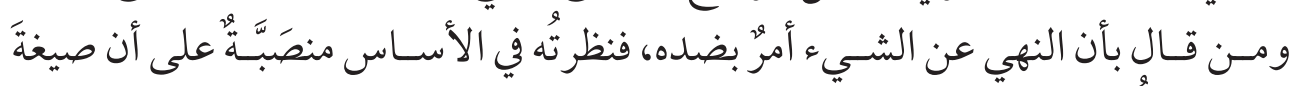

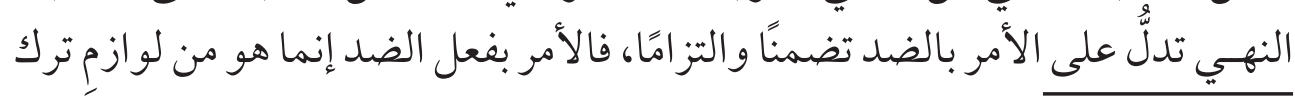

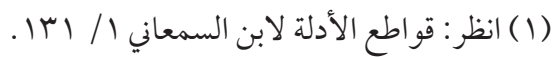

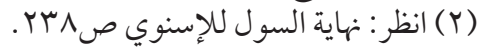

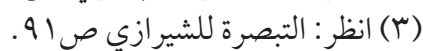

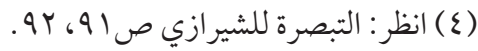




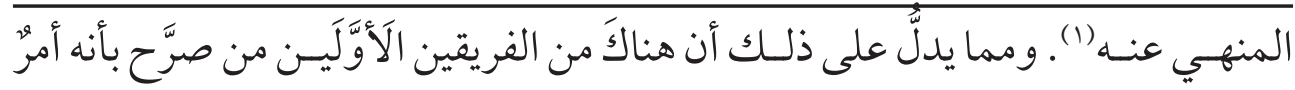

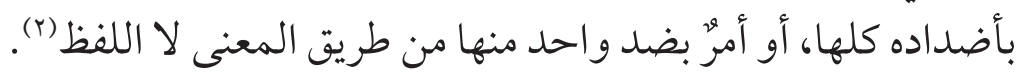

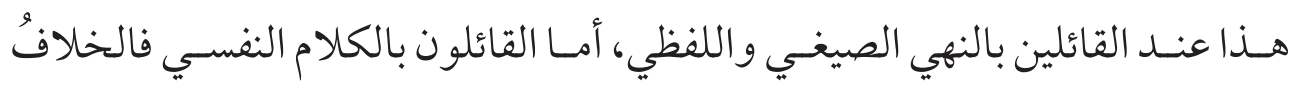

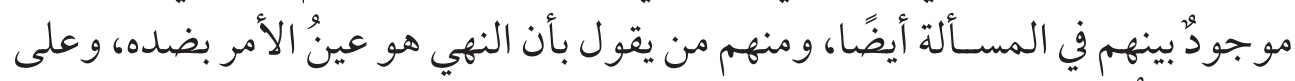

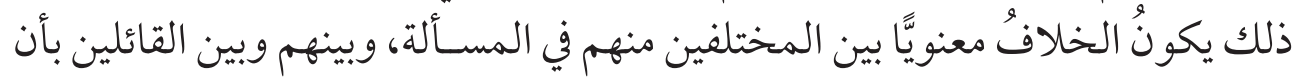

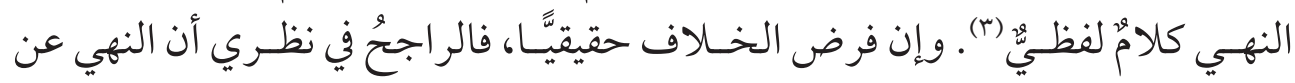

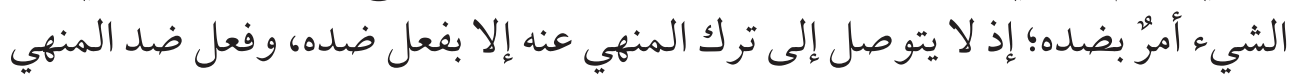

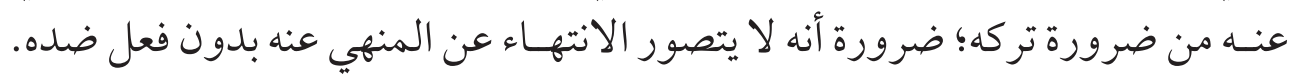
والله تعالى أعلم.

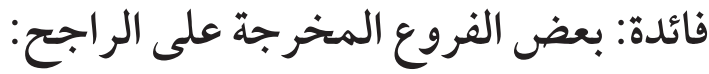

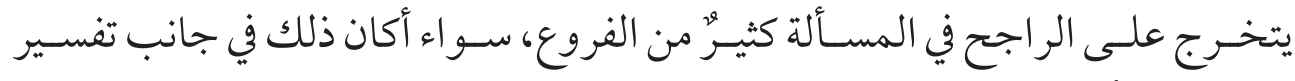

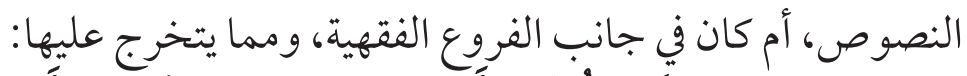

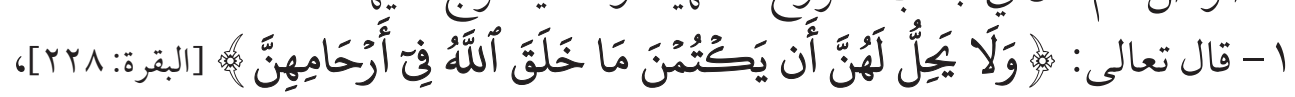

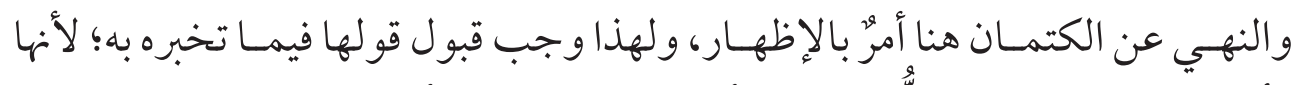

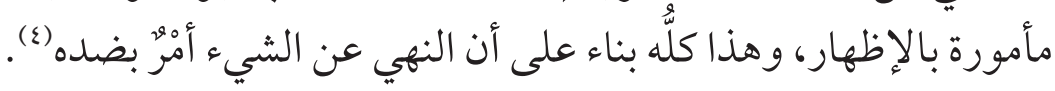

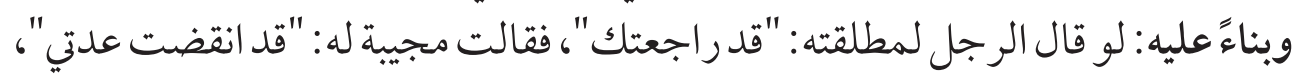

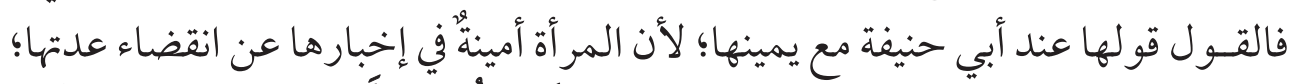

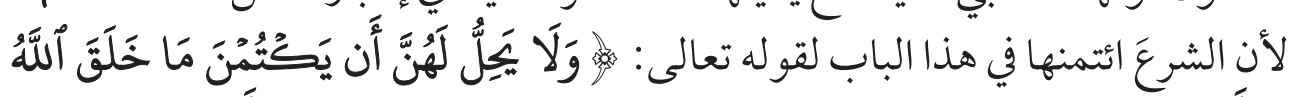

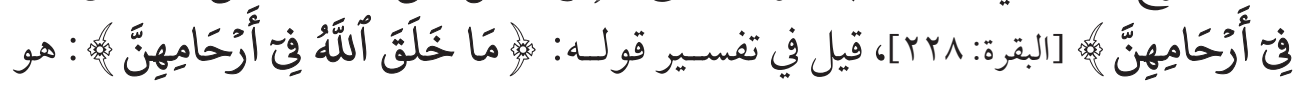

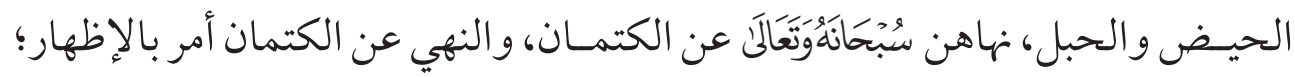

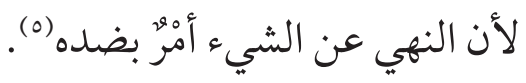

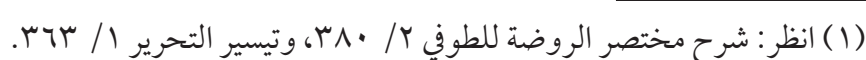

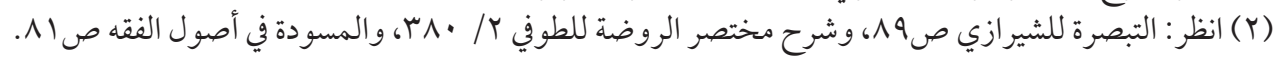




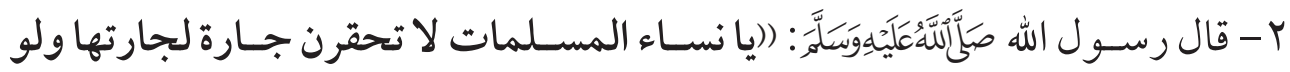

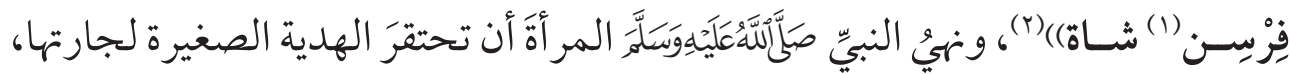

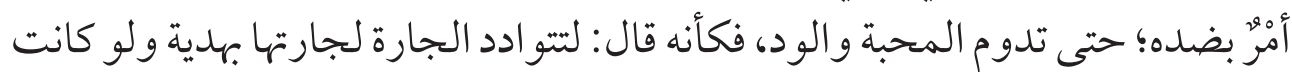
الهدية حقيرة(r).

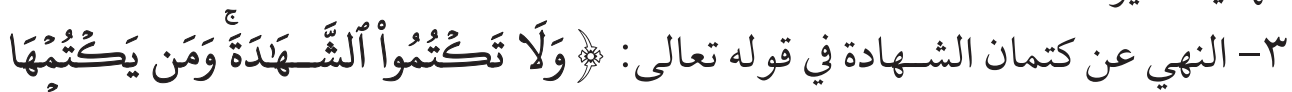

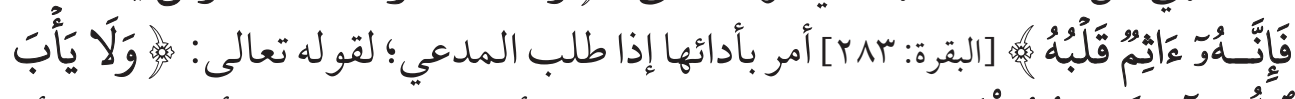

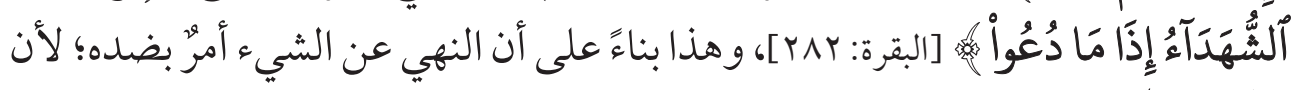

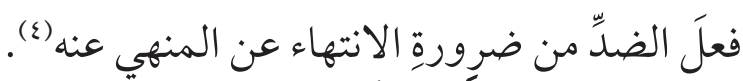

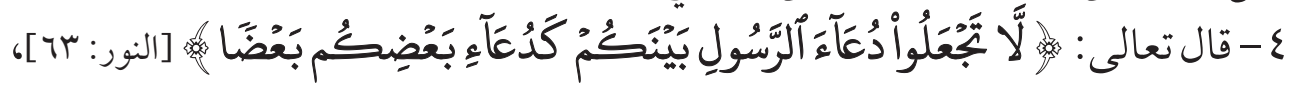

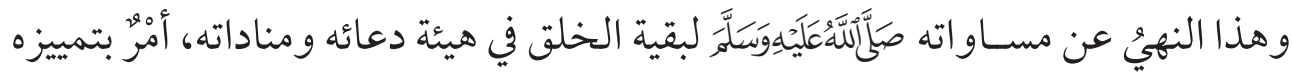

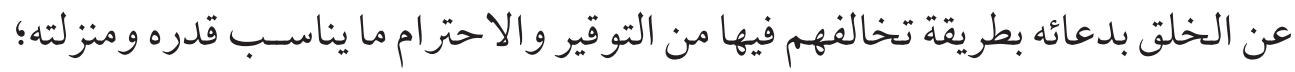

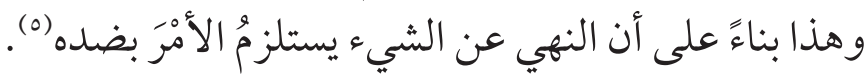

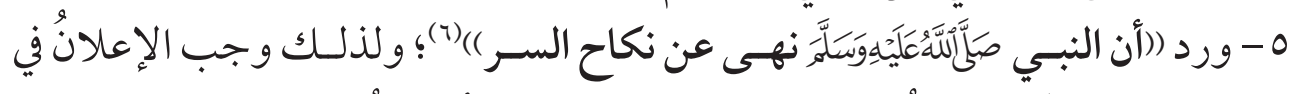

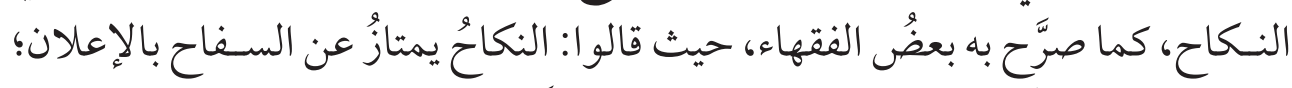

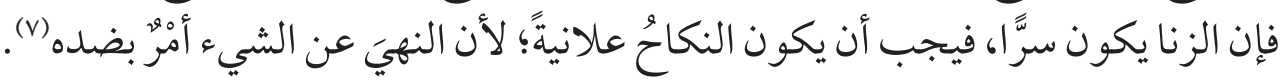

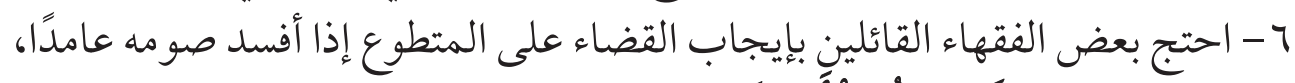

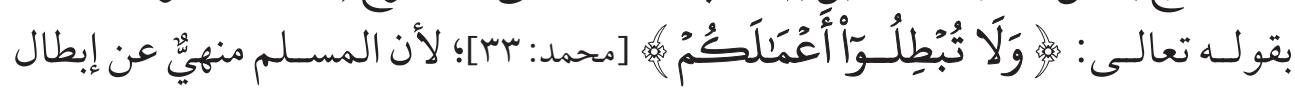

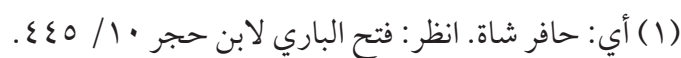

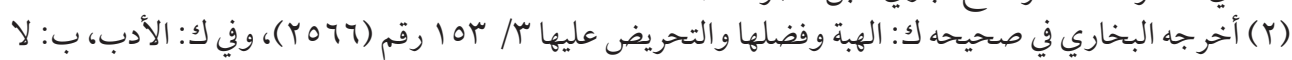

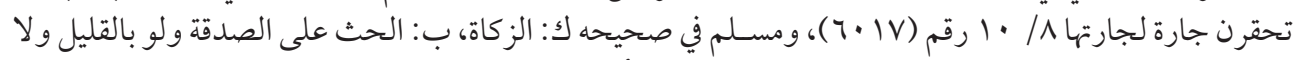

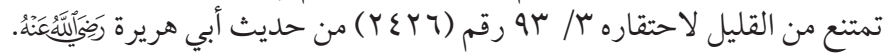

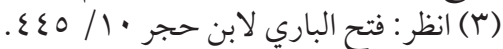

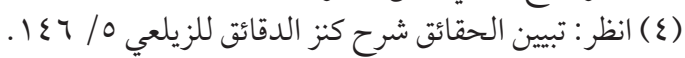

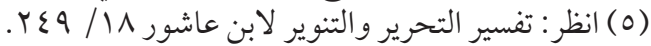

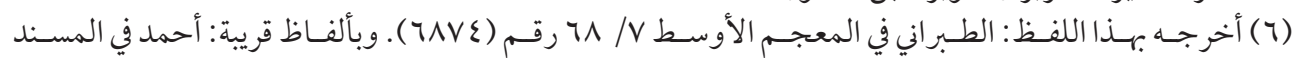

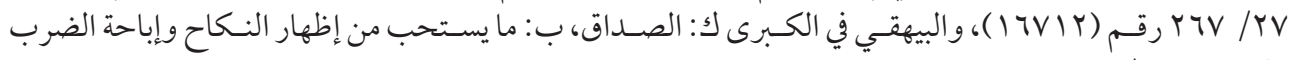

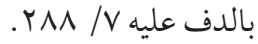

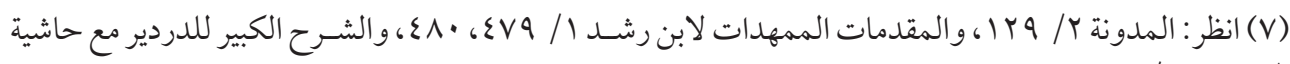

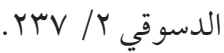




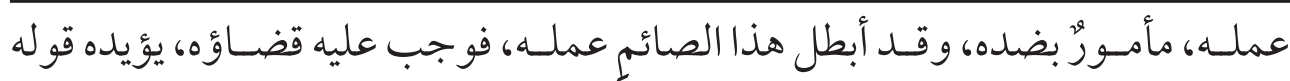

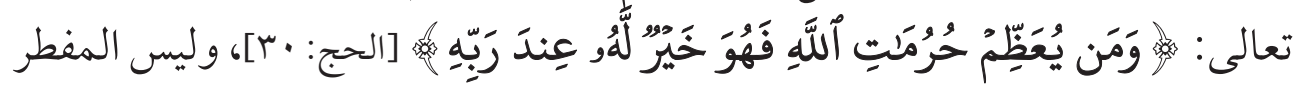

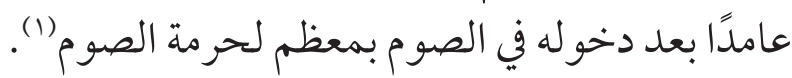

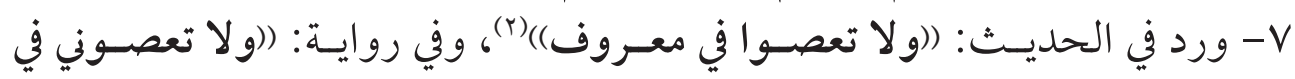

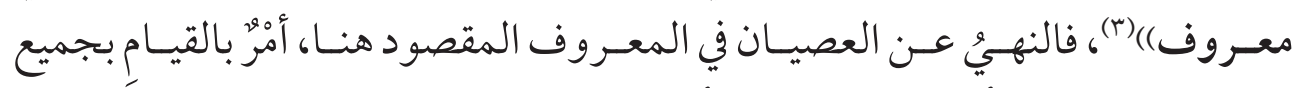

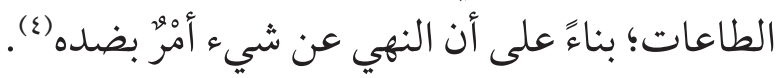

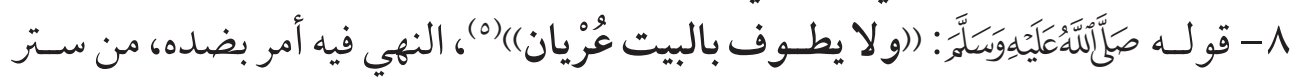

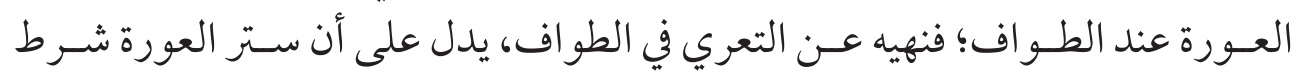

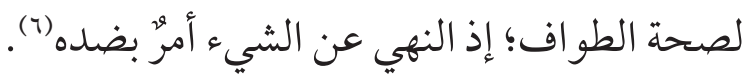

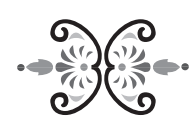

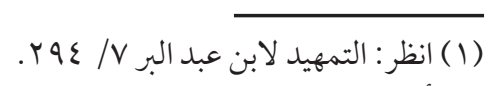

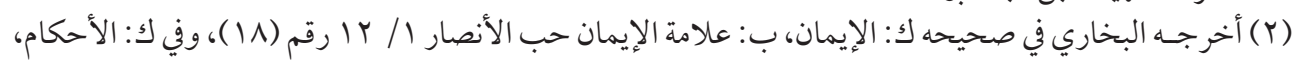

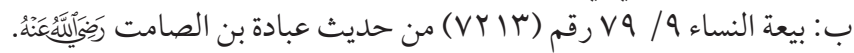

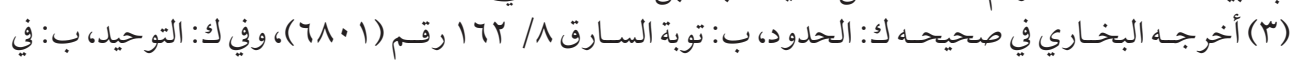

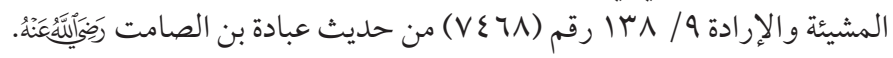

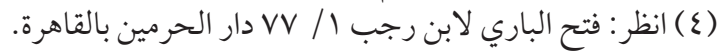

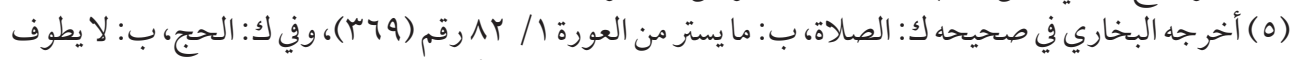

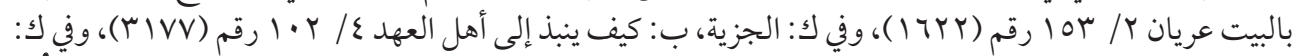

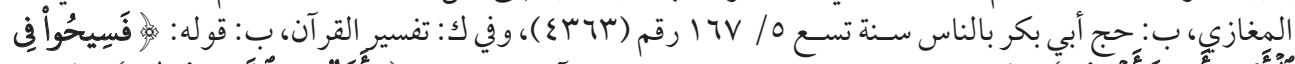

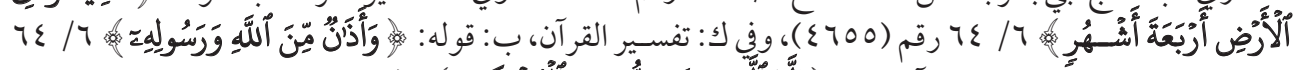

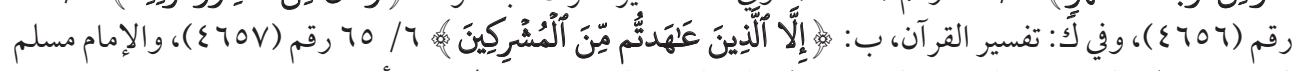

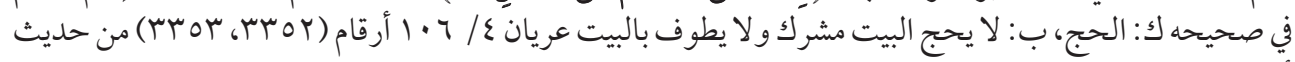

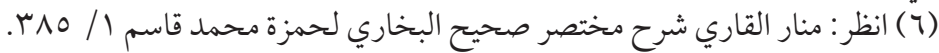




\section{الخاتمة}

أهم نتائج البحث تتلخص فيما يلي:

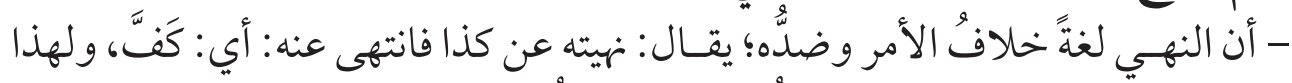

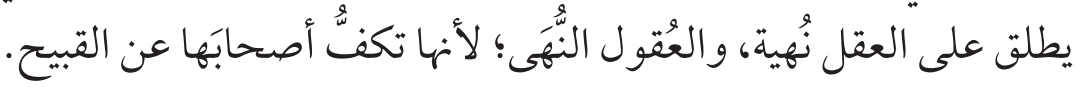

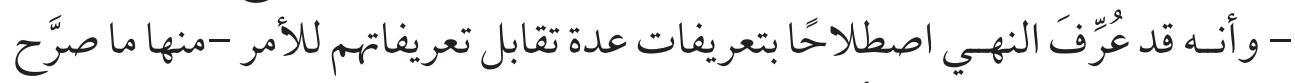

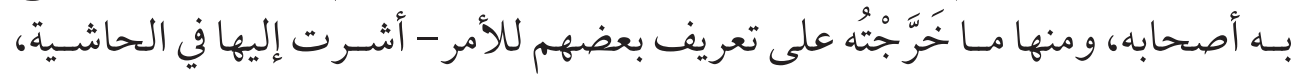

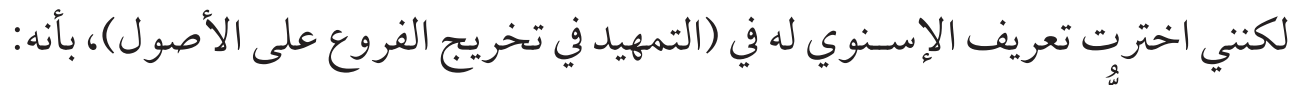

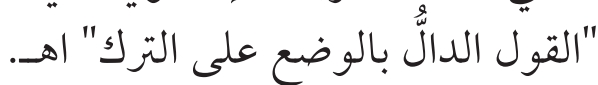

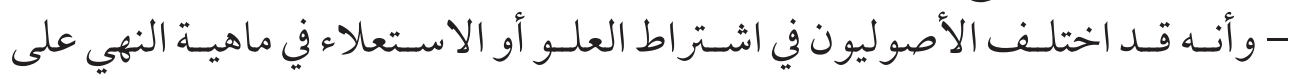
مذاهب: أولها: أن النهي هو القولُ الطالب لترك الفعل مطلقًا، سـواء أَصَدَرَ من الأعلى للأدنى، ألَّ،

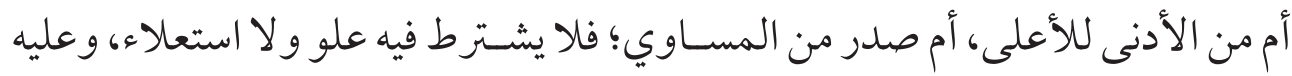
الجمهور. وثانيها: أن النهي هو القول الطالب لترك الفعل بشرط صدوره من الأعلى للأدنى، أي:

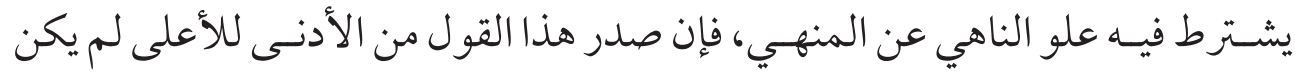

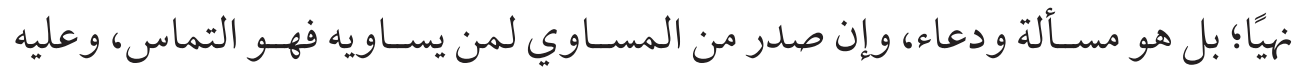
جمهور المعتزلة وجماعة.

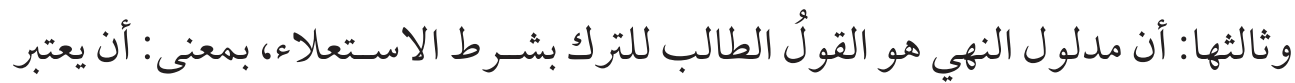

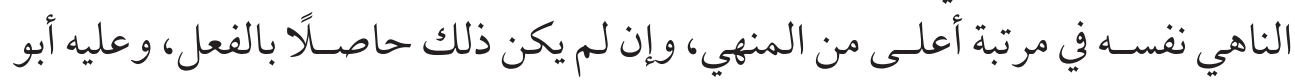

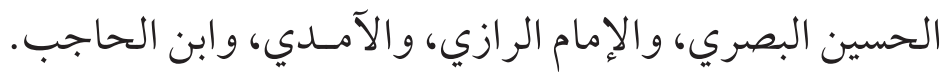

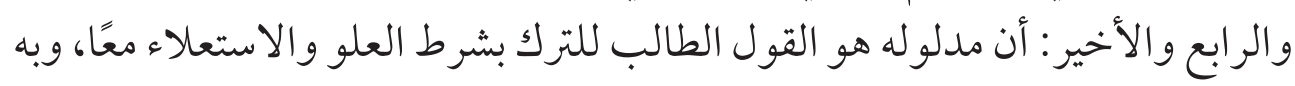
جزم ابن القشيري، و القاضي عبد الواضير الوهاب.

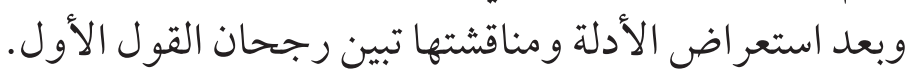

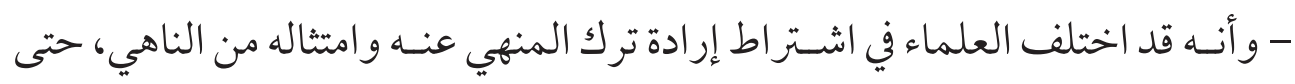

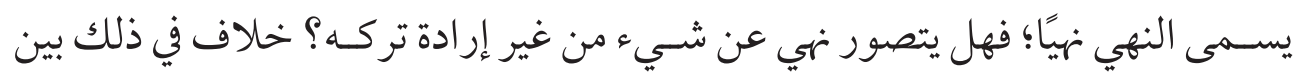




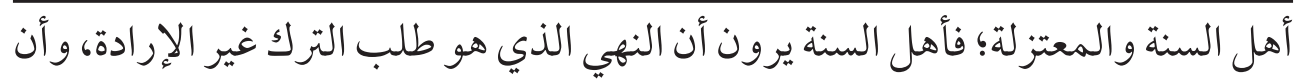

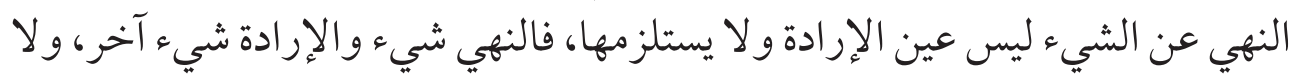

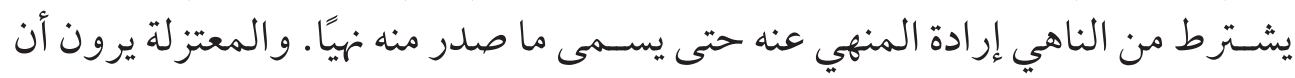
الإر ادة شرط في النهي، فالنهي عين الإرادة.

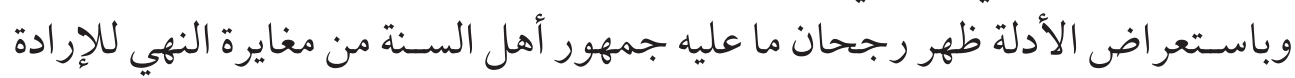

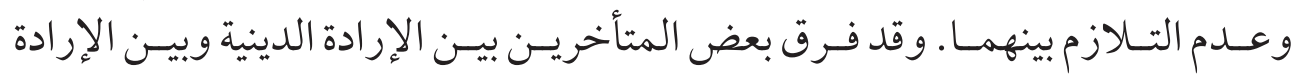

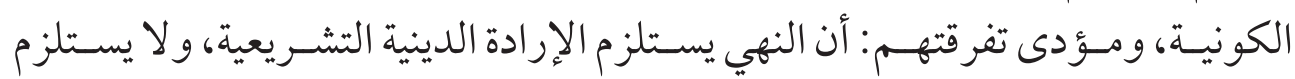

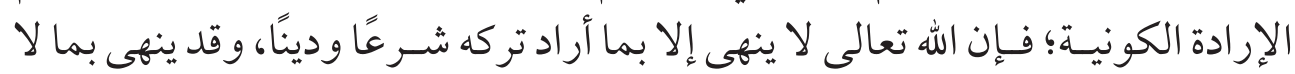

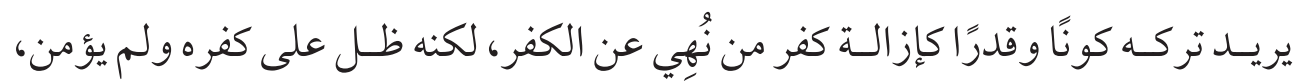
وفائدته العزم على الامتثال وتوطين النفس عليه.

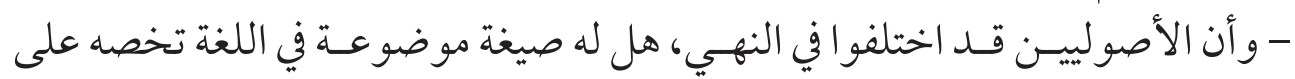
قولين: أولهما: أن للنهي صيغةً مو ضوعةً في اللغة تدلُّ على ترك الفعل، وهي قول القائل لغيره:

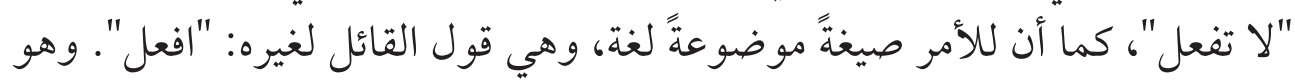

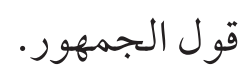

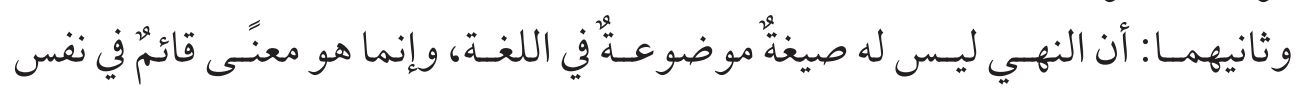
المتكلم، وعليه الأشعرية.

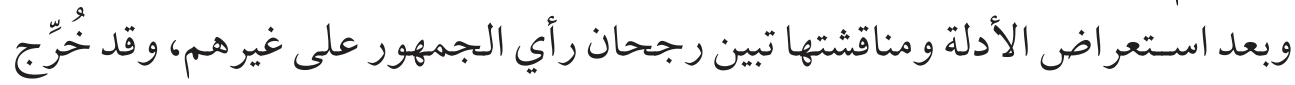

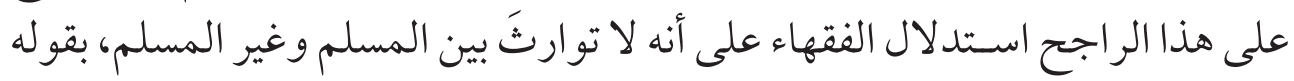

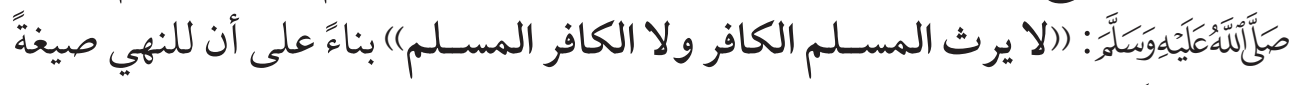

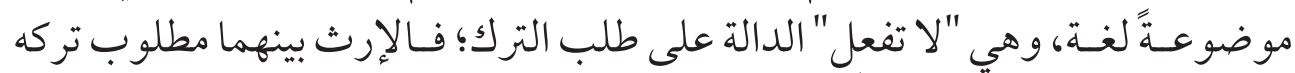

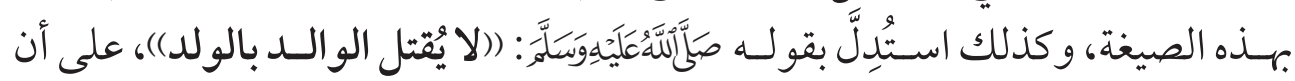

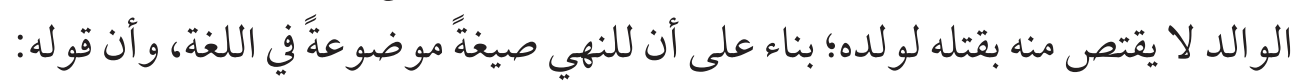

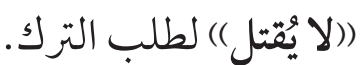

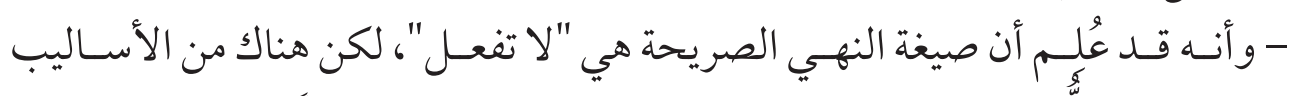

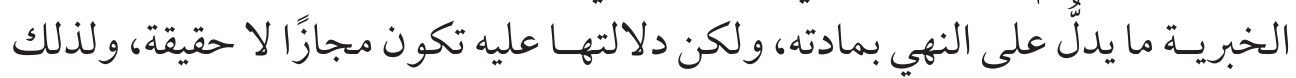




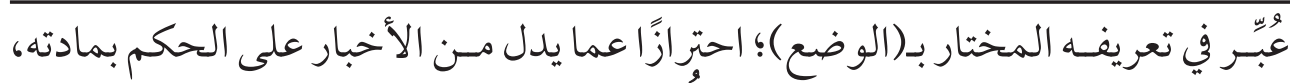

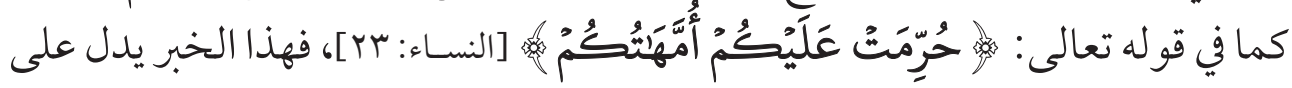
الحكى بمادته.

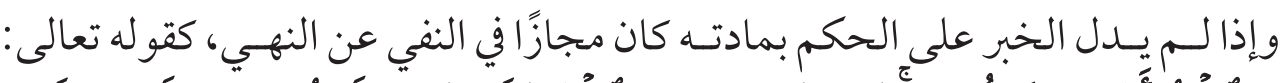

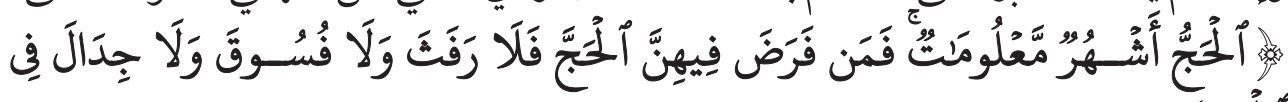

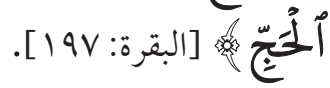
فإن" فللا رفث، و لا فسوق، و لا جدال" أخبار أريد بها النهي، أي: لا تر فثو ا، ولا تفسقوا، و لا تجادلو ا. و الدلالـة علمى النهي بالأسـلوبـ الخــري من التعبــرات البلاغية العربيـة التي تعتبره و اقعًا ملتزمًا تخبر عنه، ولكنه مع ذلك لايكون نهيًا صريحًا، بل يستعمل فيه على سبيل المجاز ـ و أن صيغـة النهي (لا تفعل) تسـتعمل في معانٍ عدة، وهــه المعاني يمتاز بعضُهـا عن بعض بحسب القرينة الدالة على المعنى المخصو ص من المعاني المذكورة، مثل ما في

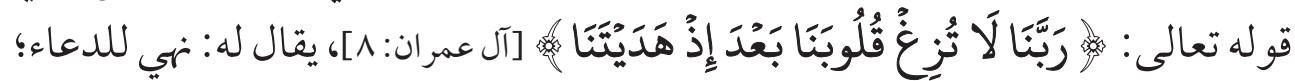

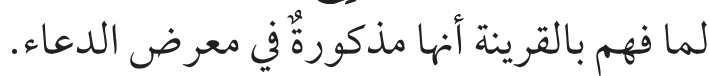
وهـي وإن عددها الأصو ليون، غير أنهم لم يتفقو اعليها، فتجد منهم المكثر فيها ومنهم المقـل و منهم من أدخل بعضها في بعض، وهذه المعاني التي ترد لها صيغة النهي هي: التحريم، الكر اهة، الإرشـاد، الدعاء، بيان العاقبة، التقليل والتحقير، اليأس، التسكين، التفويض، التحذير، الأدب، إيقاع الأمن، الالتماس، الإباحة، الخبر، التصبر، التسوية، التقرير، الاستقالول، العظة، الشفقة. ـ و أنه قد اتفق الأصو ليون على أن صيغة النهي تسـتعمل في كل المعاني السـابقة، يؤيد

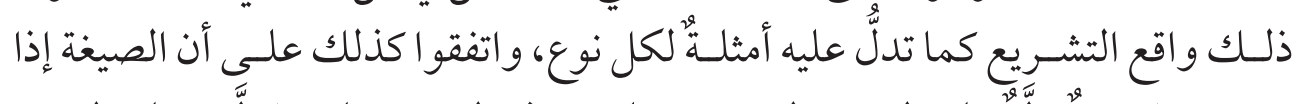

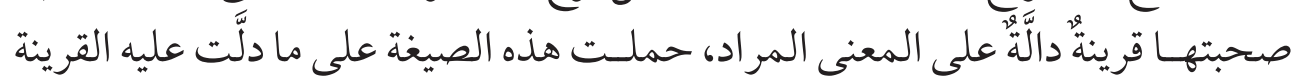
و حددتـه، و اتفقو اكذلك على أنها ليسـت حقيقة في جميع هـذه المعاني؛ لأن أكثر ها لم يغهم من صيغة (لا تفعل) لكن فهم بالقرينة، و إنما الخلاف في بعضها. 
و اختلفو ا -بعد اتفاقهم السابق - فيما تستعمل فيه من هذه المعاني على سبيل الحقيقة،

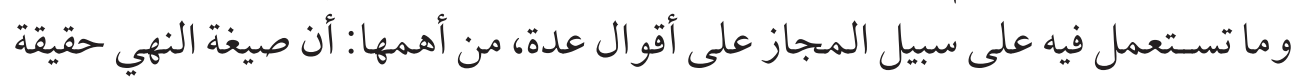

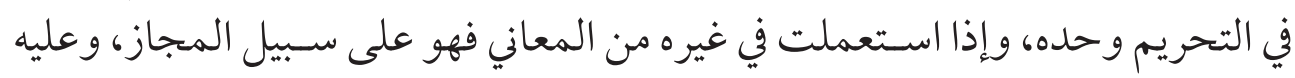

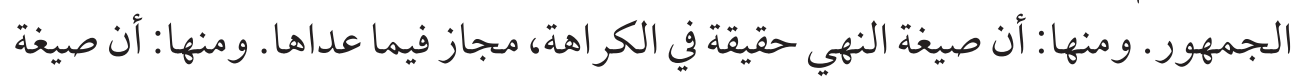

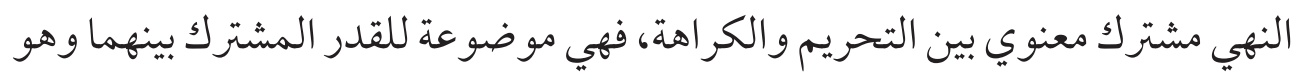
مطلق طلب الترك. ومنها: أن صيغة النهي مشـترك لفظي بين فين التحريم و والكر اهة، فهي

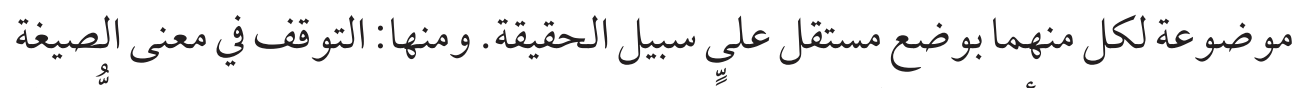

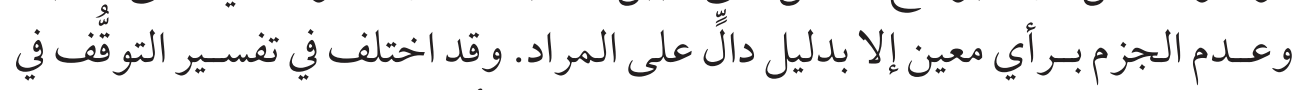

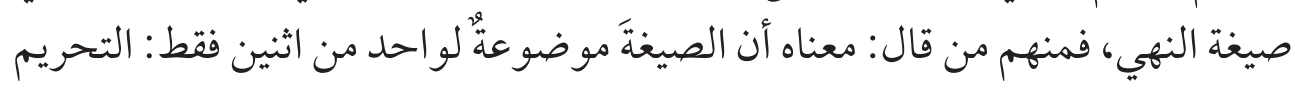

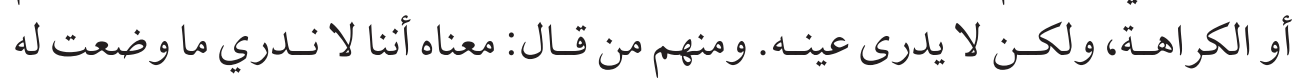

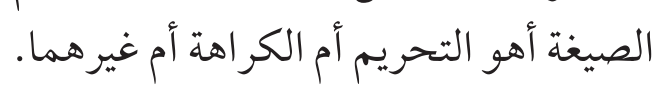

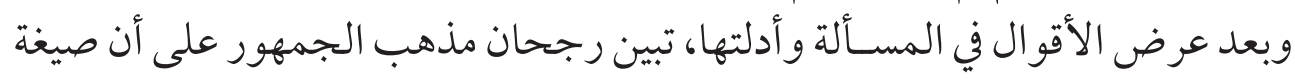
النهي موضوعة حقيقة للتحريم، وإذا استعملت في غيره فهو على سبيل المجاز.

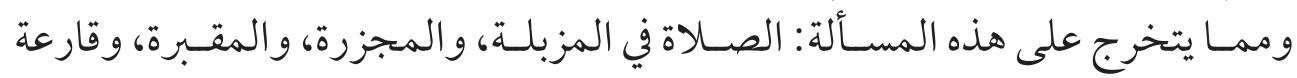

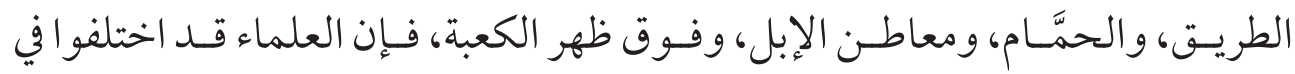

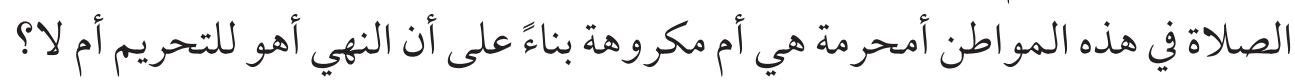

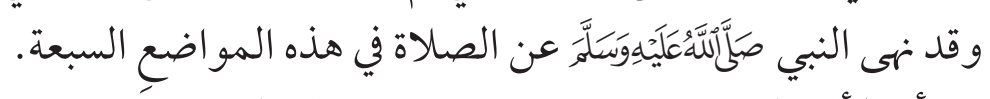

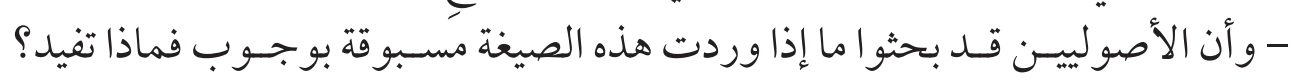

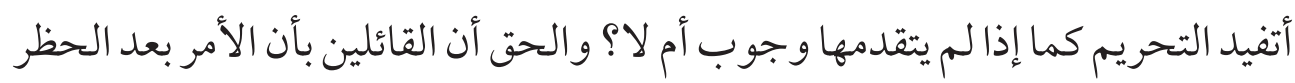

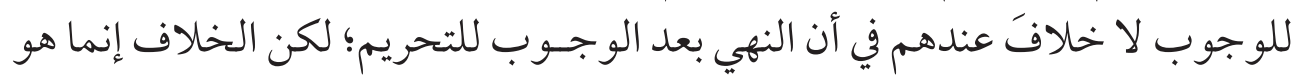

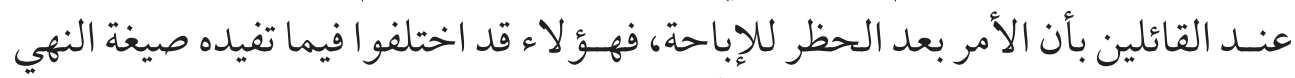

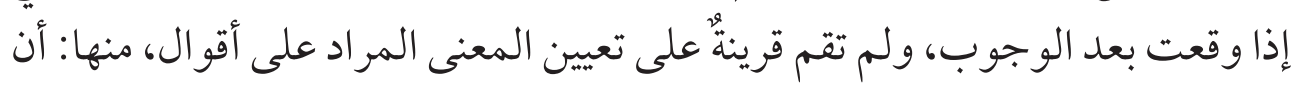

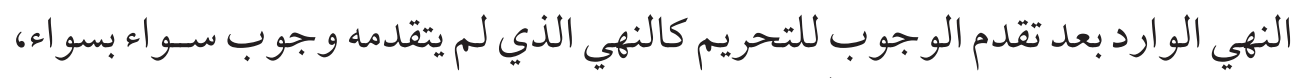

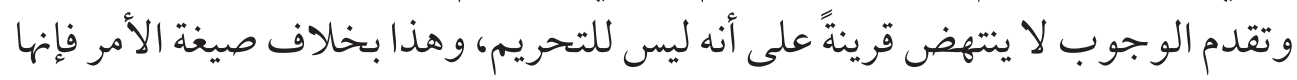

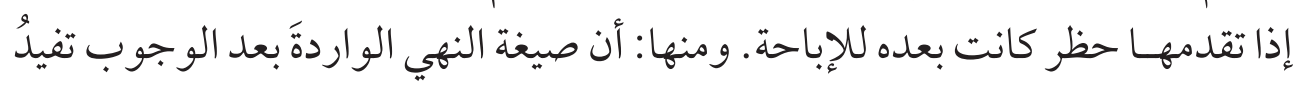

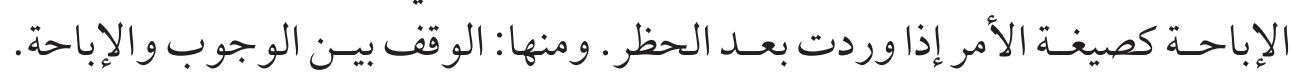


ومنها: أن صيغة النهي بعد الوجوب للكر اهة. ومنها: أن النهي بعد الوجوب لإسـقاط الوجوب، ويرجع الأمر إلى ما كان قبله من تحريم أو إباحة.

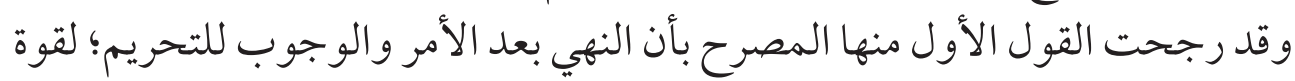

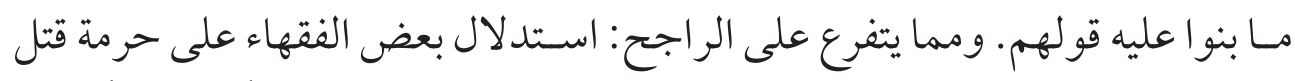

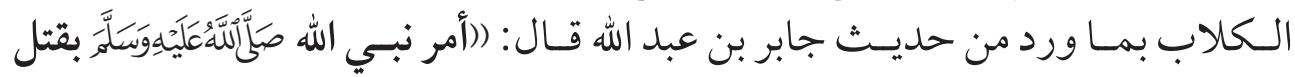

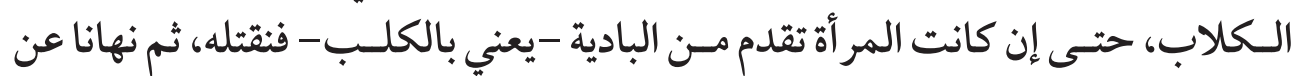

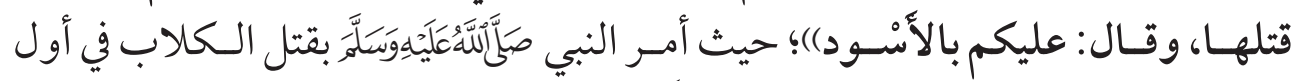

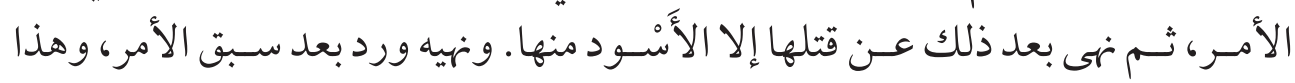
النهي للتحريم لا فرق بينه وبين نهي وارارد ابتداء، فلا يجوز قتل شيء شئ منها إلا ما استشني.

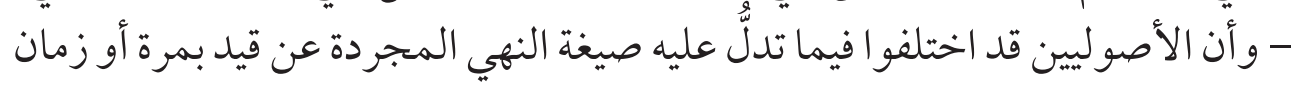

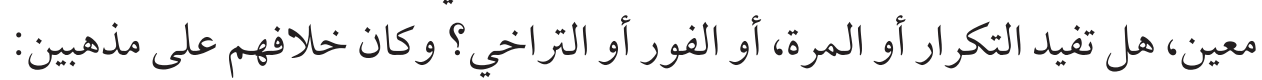

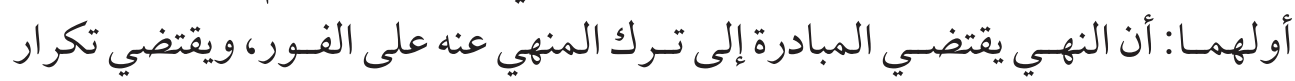

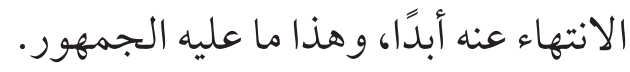

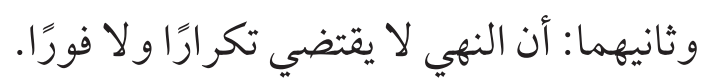

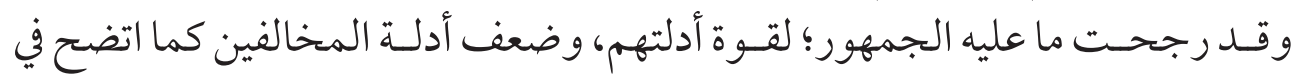

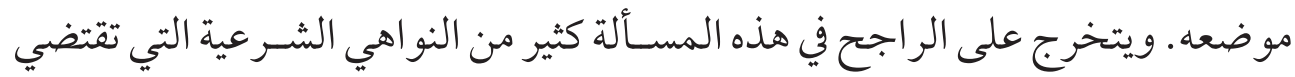

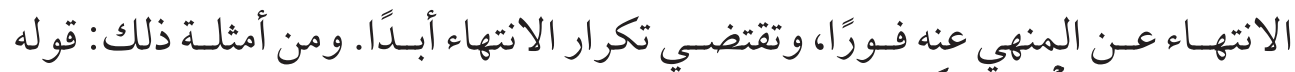

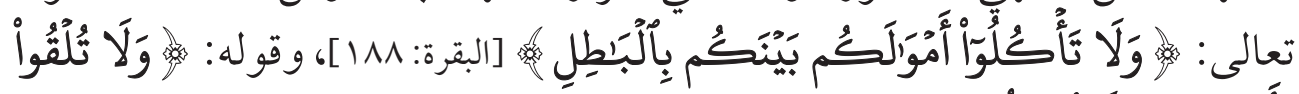

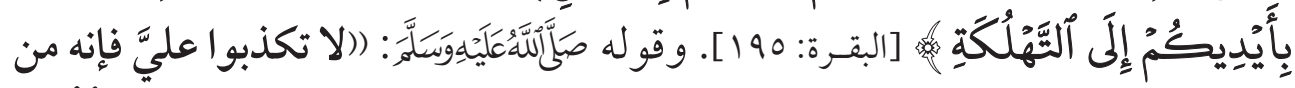

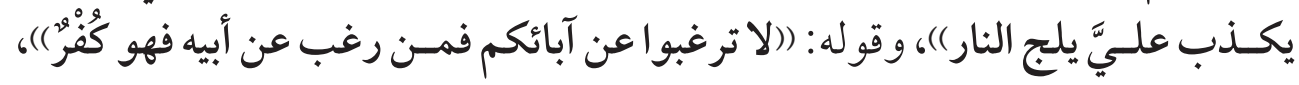
وغير هذا من النصوص الشرعية الكثير. - و أن النهي إن قيد بالتكرار فهو للتكرار، و ولا خلاف فئه فيه، أما إن قيد بالمرة فقد اخْتُلف فيه على قولين: أحدهما: أن النهي إن قيّيّد بالمرة حمل علئ عليها.

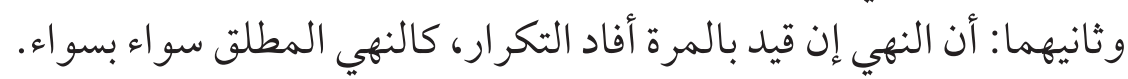
- و أن النهي إن قيد ان بالترئراخي حمل عليه. 
- و أنهم قد اختلفو اكذلك في النهي المعلق بما يتكرر كالشر ط و الصفة، فمن قال: النهي

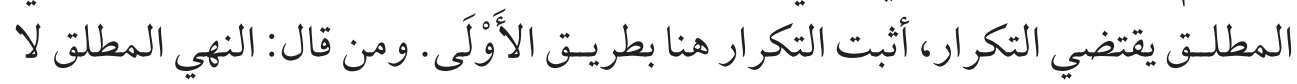

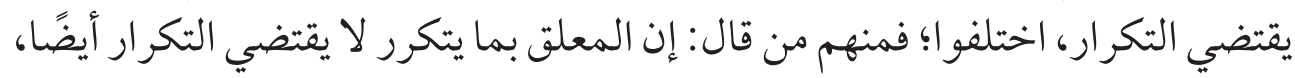

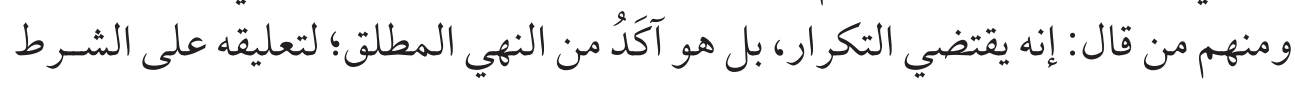
و الصفة.

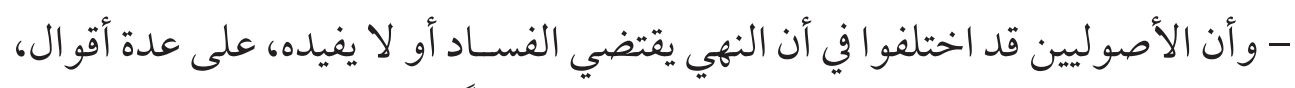

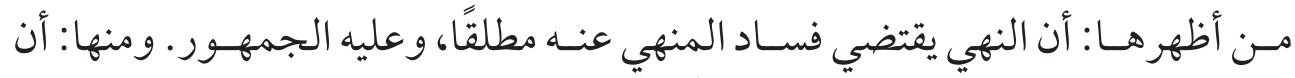

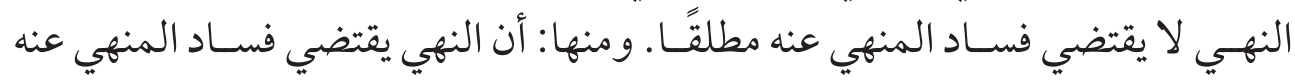

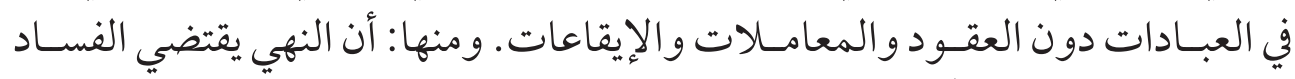

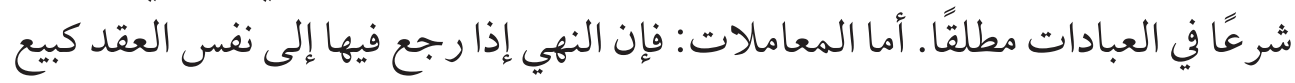

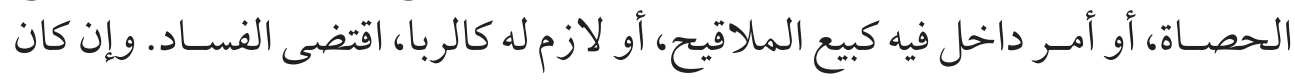

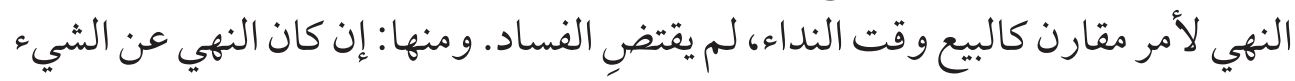

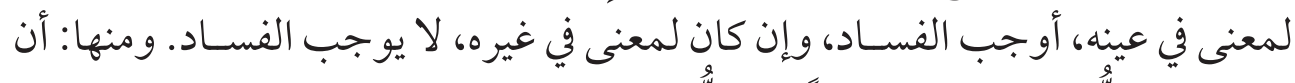

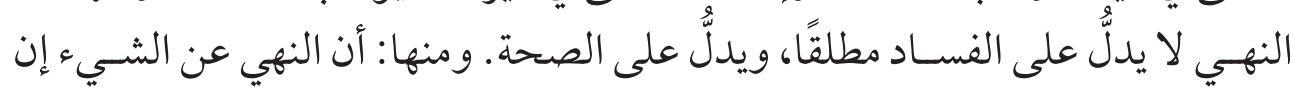

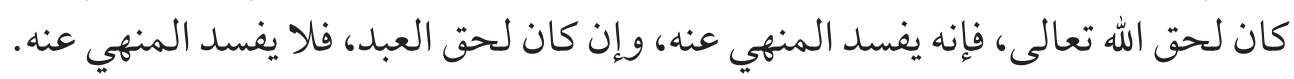

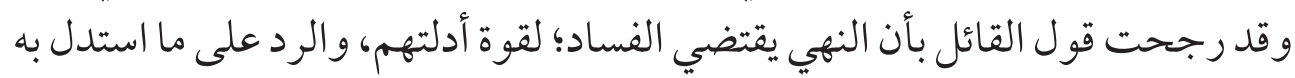

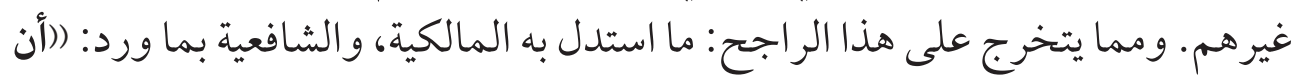

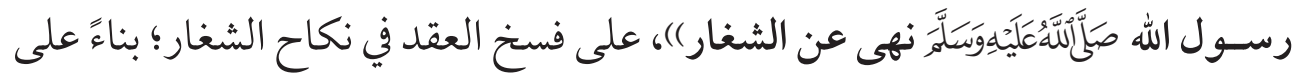

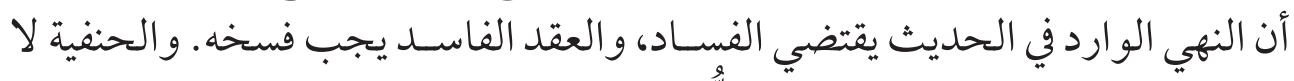

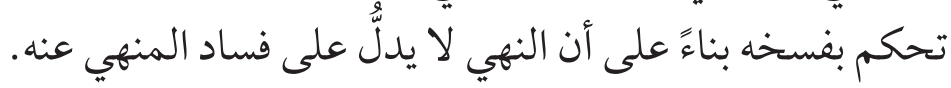

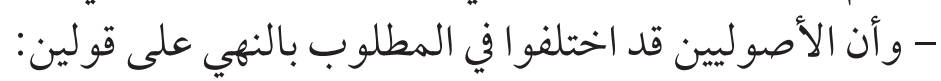

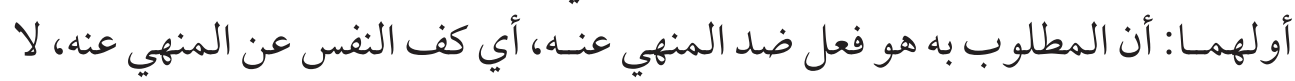

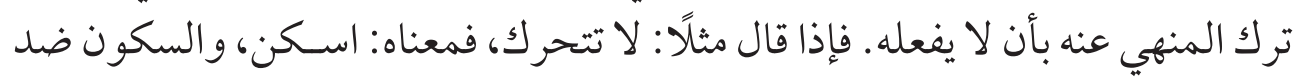

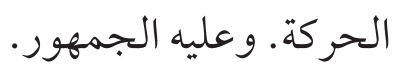

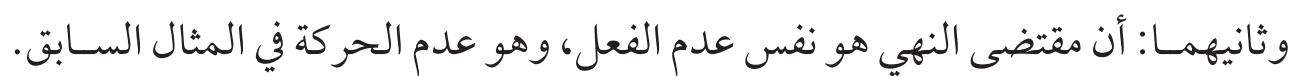

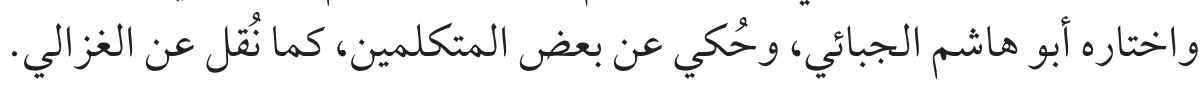

Av


- و أن النهـي إن كان عن شـيء و واحـــ فهو ظاهر لا كلام فيـه، وإن كان عن متعدد فهو على أقسام: الأول: أن يكــون النهي عن الجمع بين أشـياء، أي: الهيئـة الاجتماعية دون المفردات

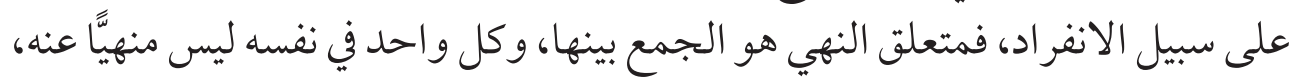

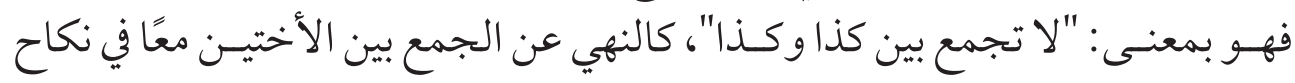

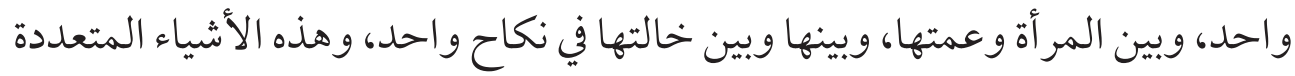

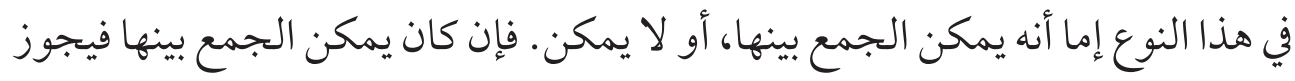

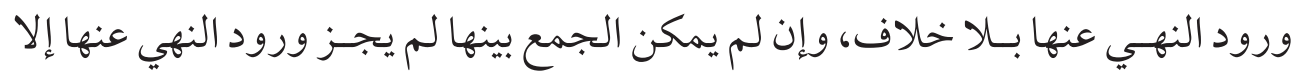
عند من يجوز التكليف بما لا يطاق.

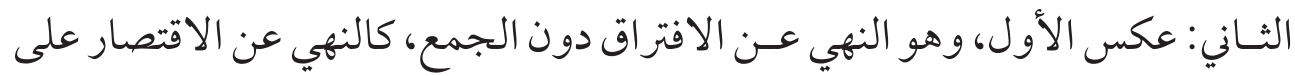

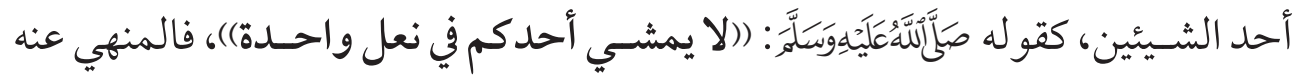

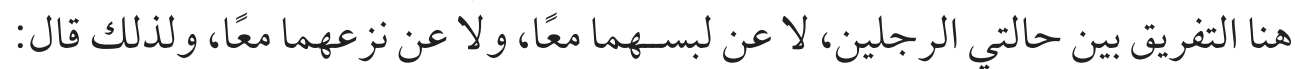

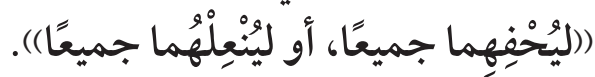

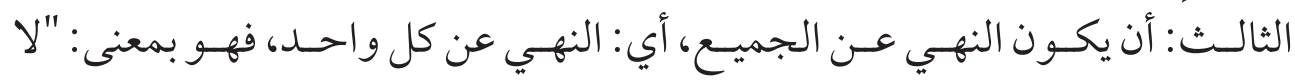

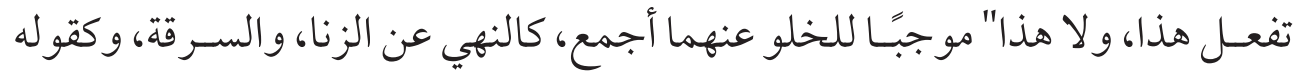

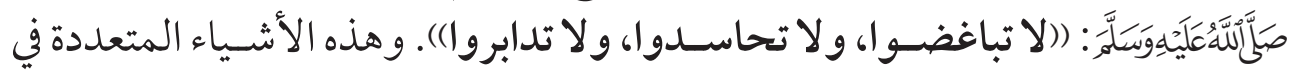

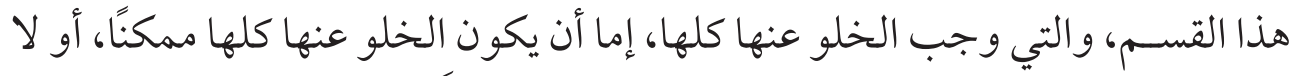

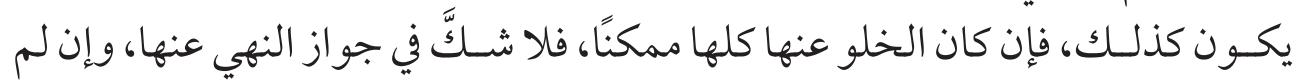

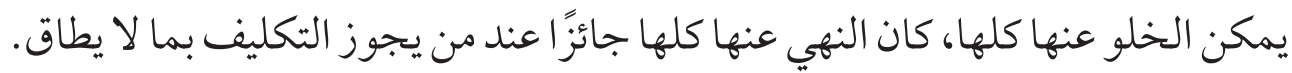

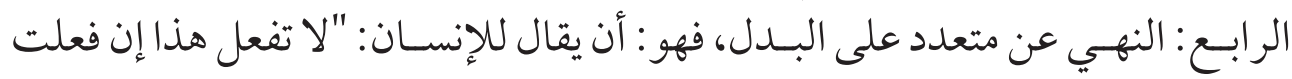

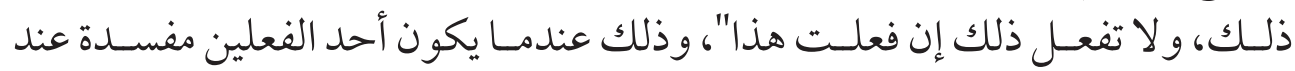

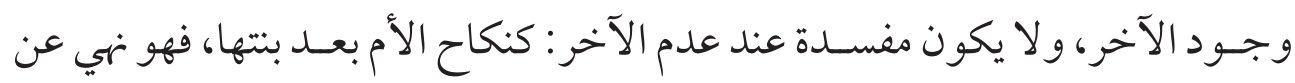

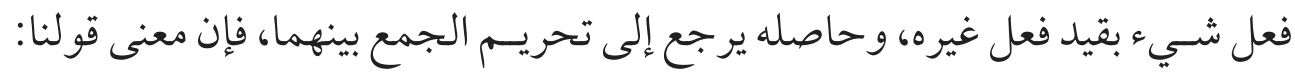

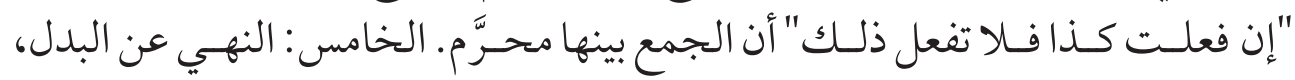
وذلك يفهم منه شيئان: 
أحدهما: أن ينهى الإنسانَ عن فعل شيء وجعله بدلًا عن غيره، كجعل التصدق بدرهم

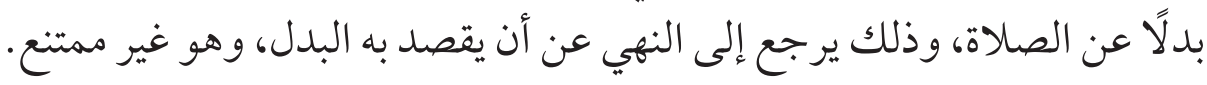

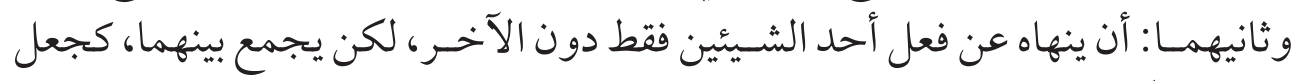

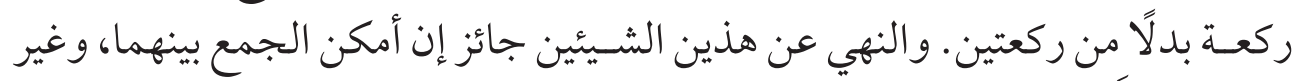

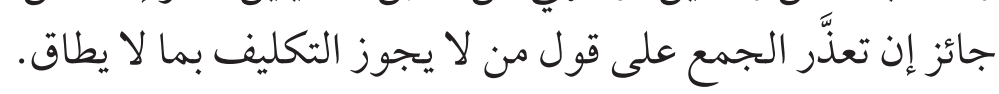

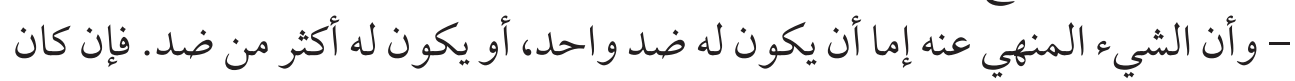

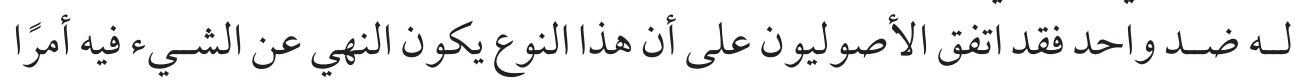

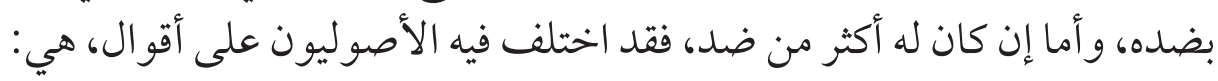
القول الأول: أن النهي عن الشيء أمر بأضداده كلها.

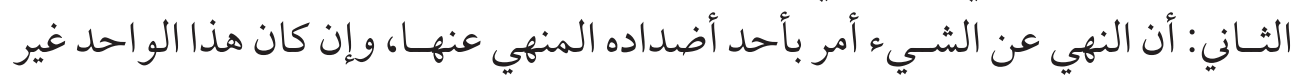
معين.

الثالث: أن النهي عن الشيء ليس أمرًا بضده مطلقًا.

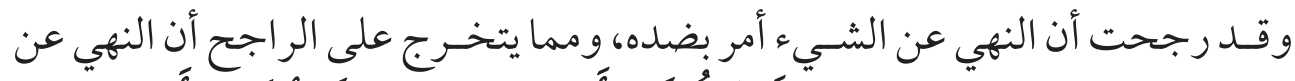

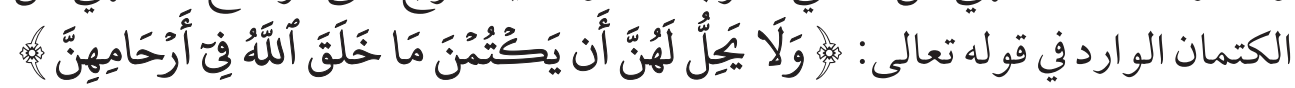

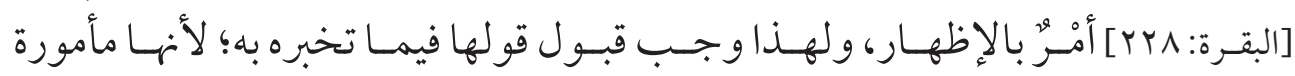

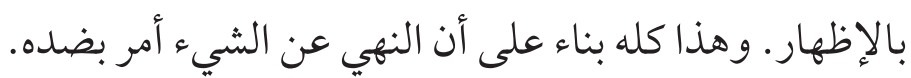

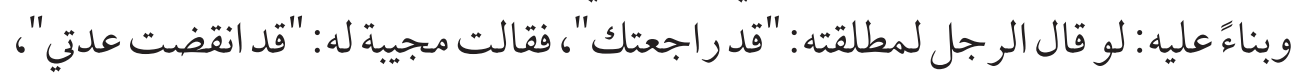

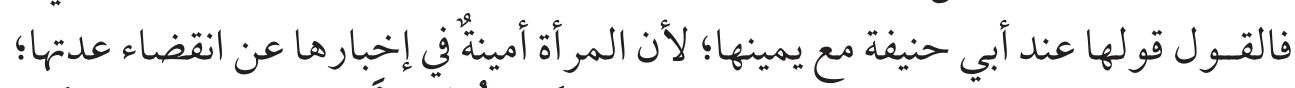

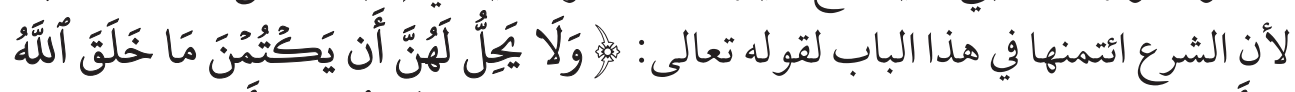

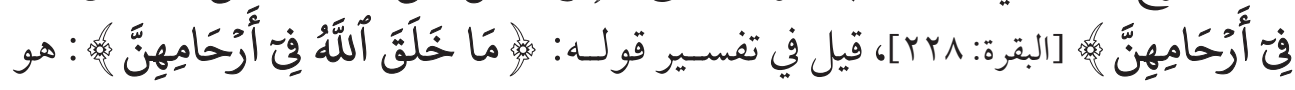

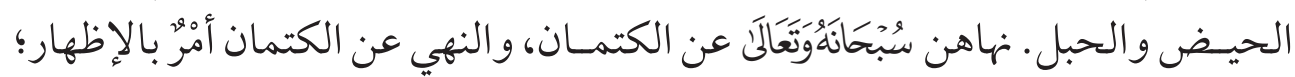
لأن النهي عن الشيء أمر بضده. والله تعالى أعلى وأعلم، وآخر دعوانا أن الحمد لله رب العالمين

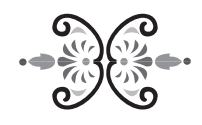




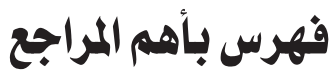

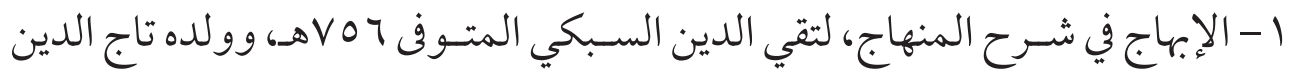

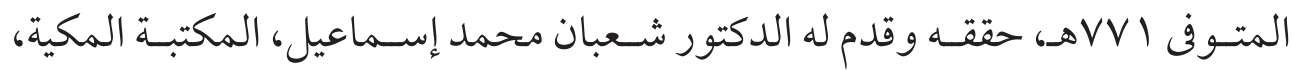

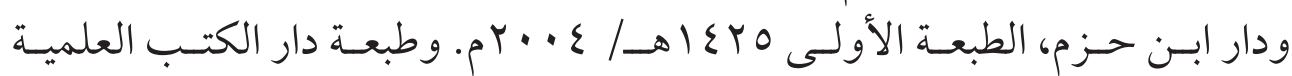

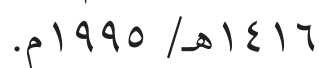

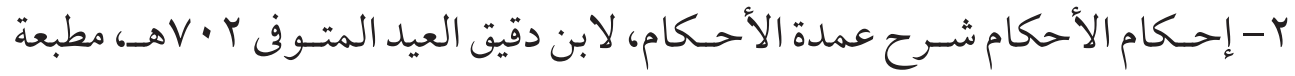
السنة المحمدية، بدون طبعة وبدون تاريخ.

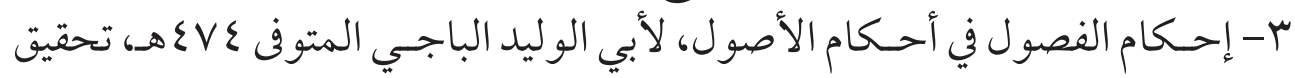

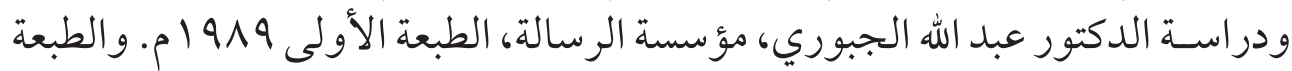

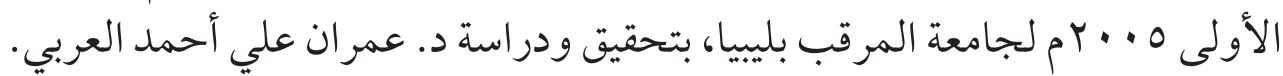

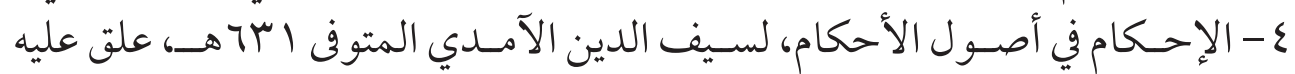

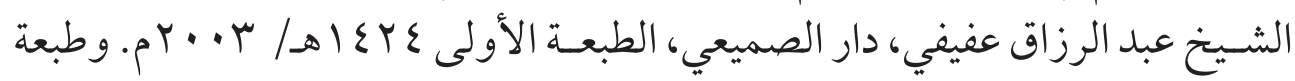

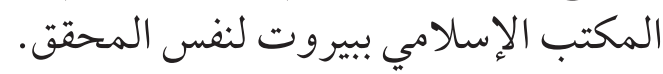

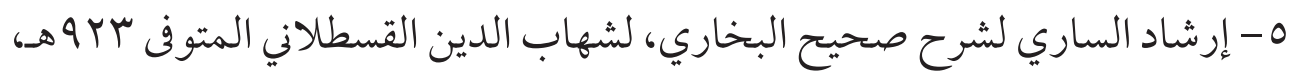

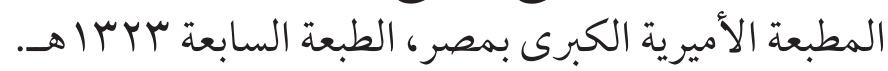

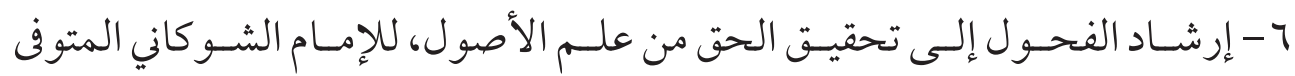

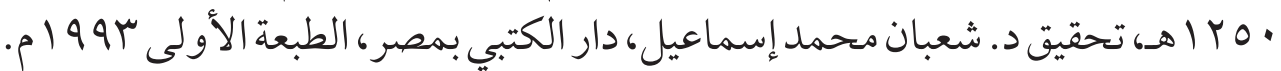

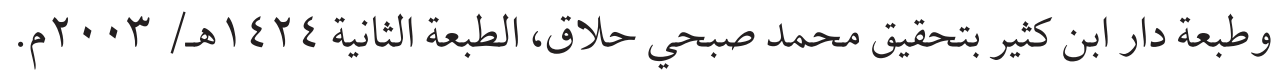

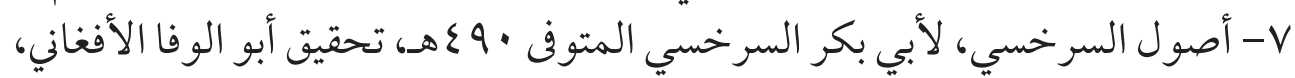

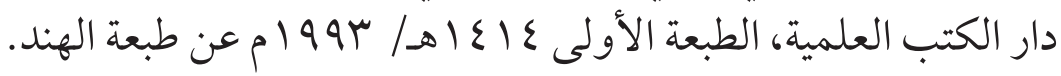

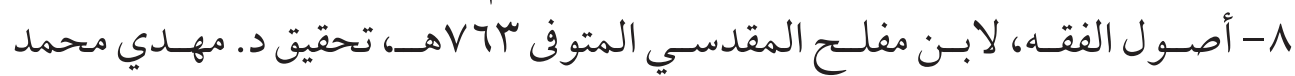

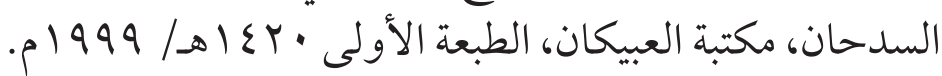

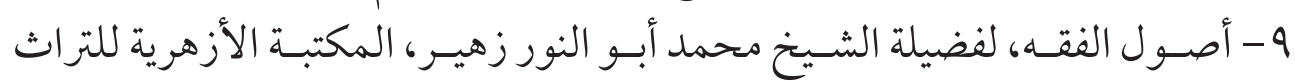

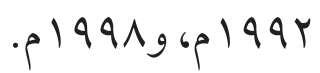
• 1 - أصـول الفقه الذي لا يســع الفقيـه جهله، للدكتور عياض بن نامي الســلمي، دار

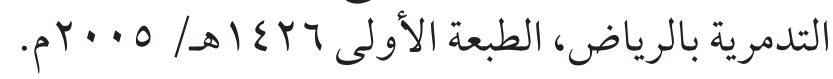

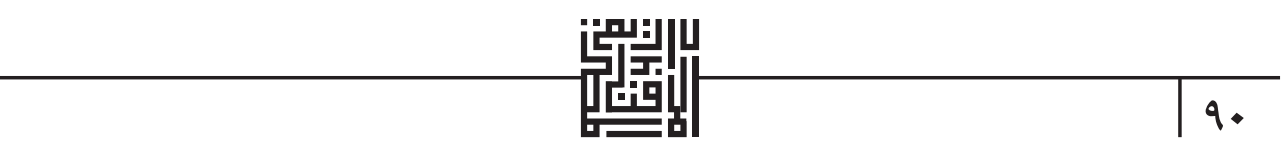




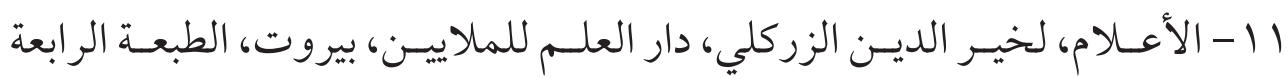
. $19 \vee 9$

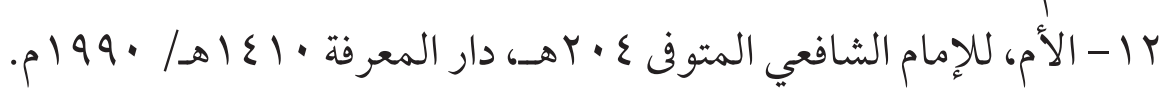

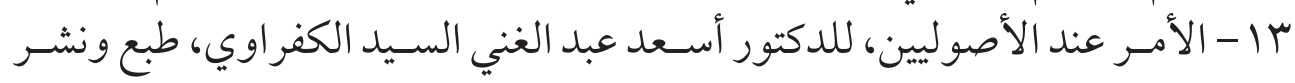

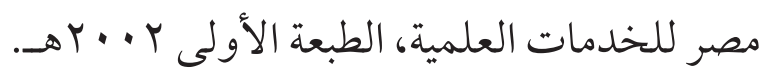

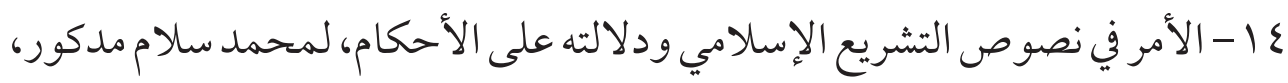

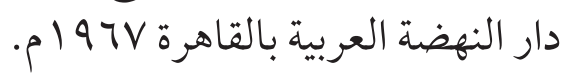

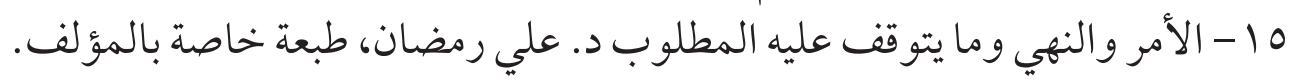

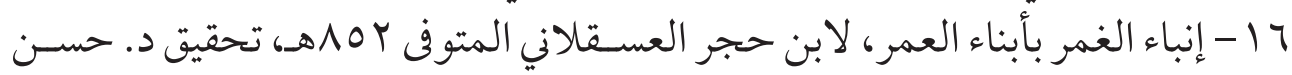

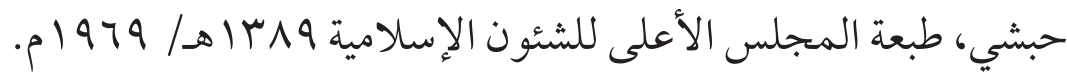

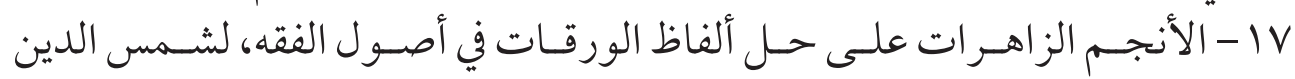

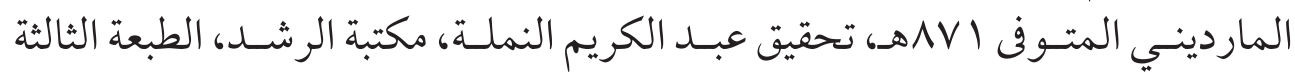

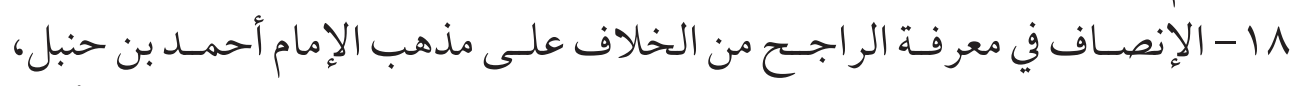

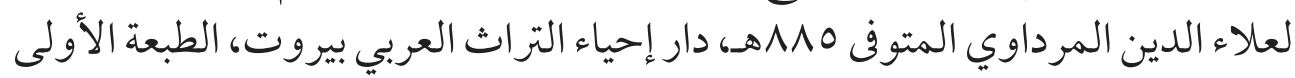
. $1 \leqslant 19$

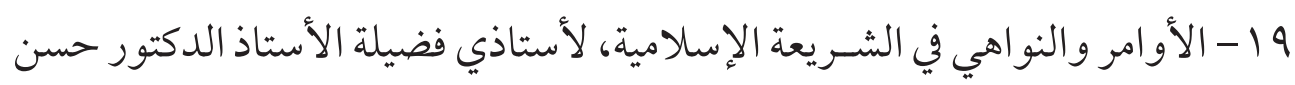

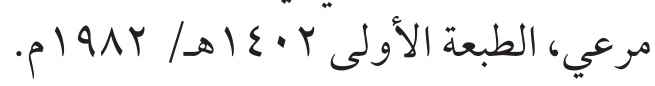

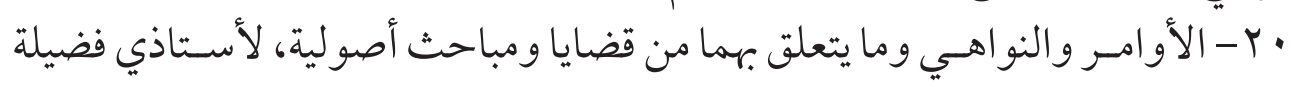

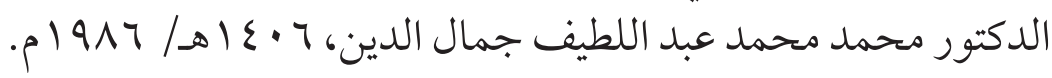

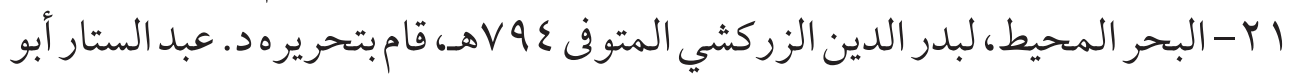

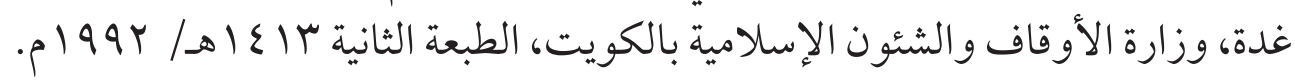

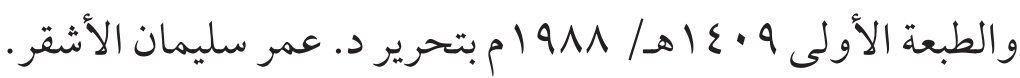

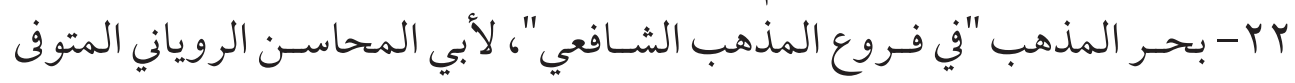

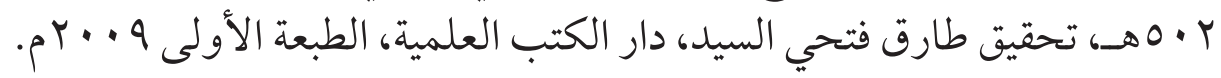

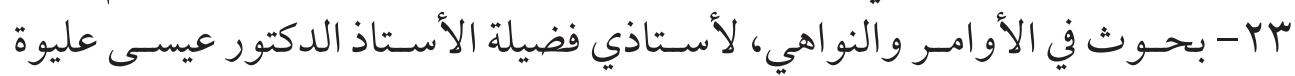

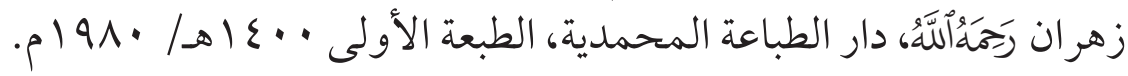




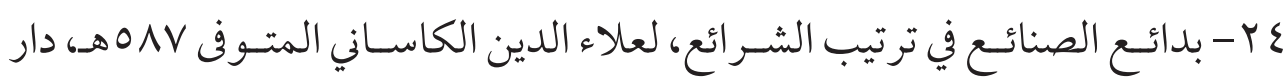

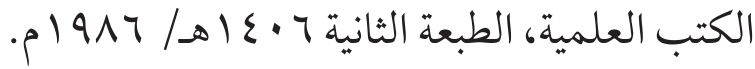

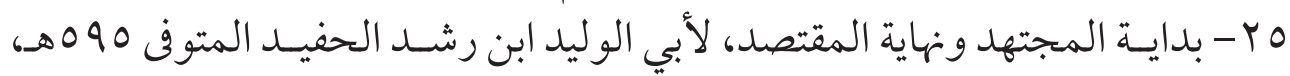

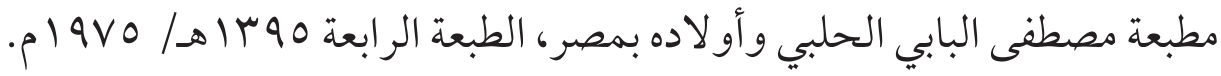

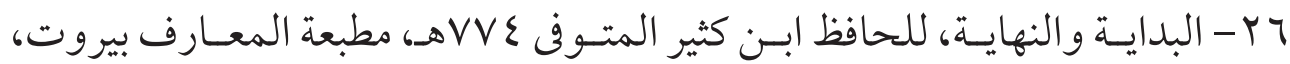

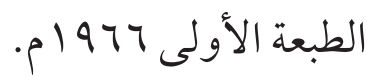

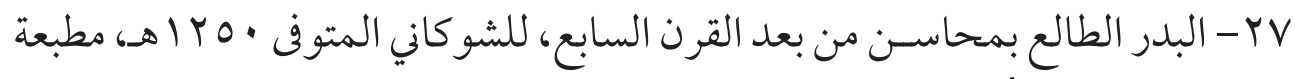

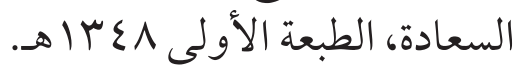

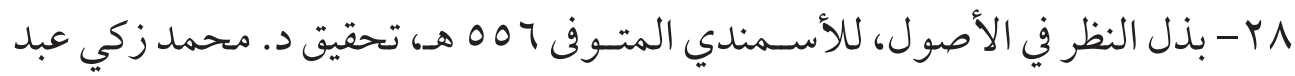

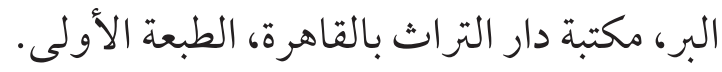

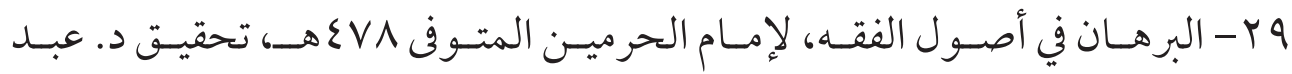

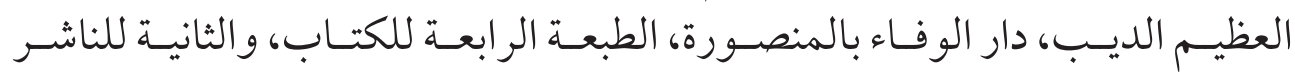

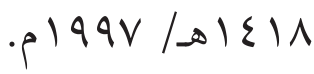

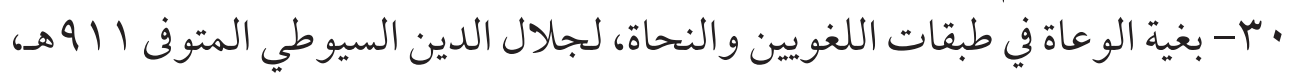
تحقيق محمد أبو الفضل إبراهيم، دار الفكر و 9 أب م.

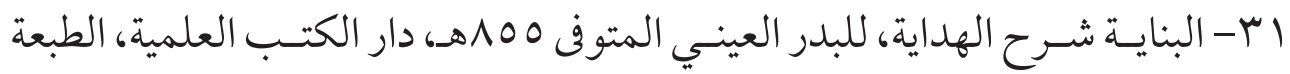

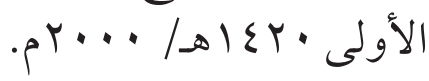

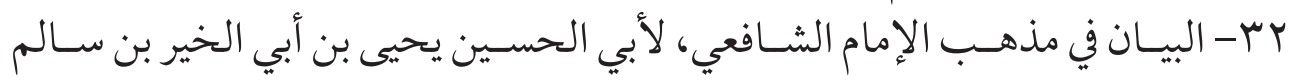

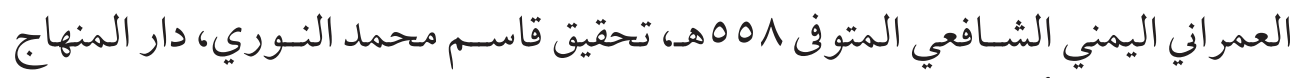

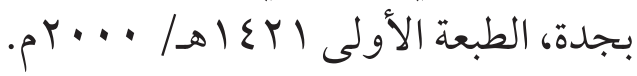

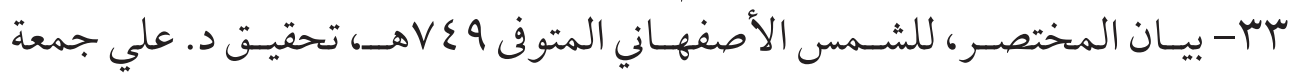

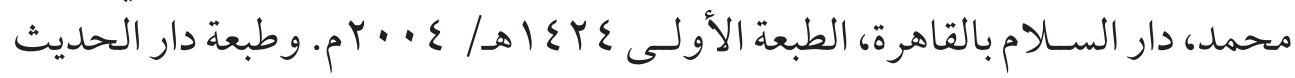

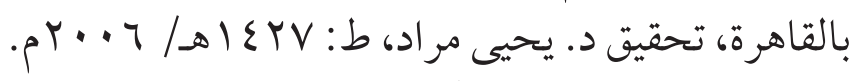

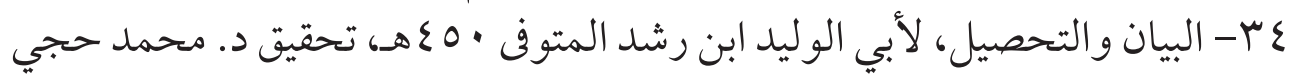

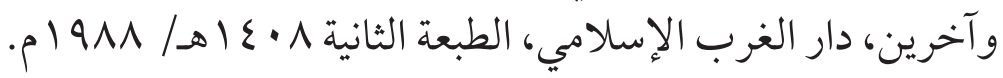




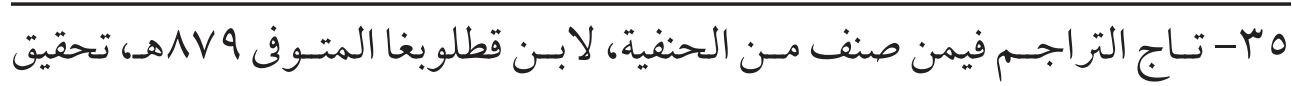

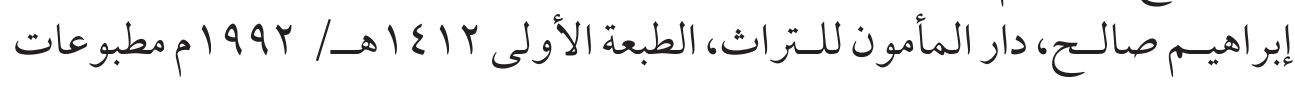
مركز جمعة الماجد للثقافة والتراث بدبي.

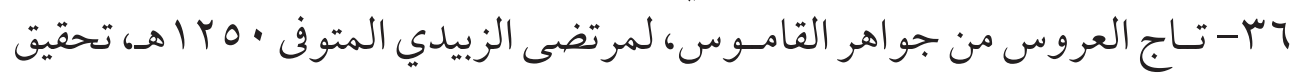
مجموعة محققين، دار الهداية.

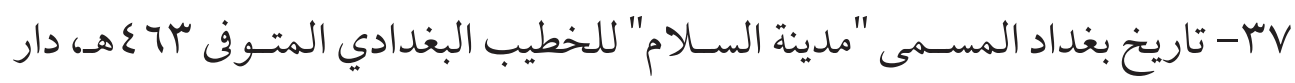

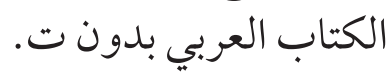

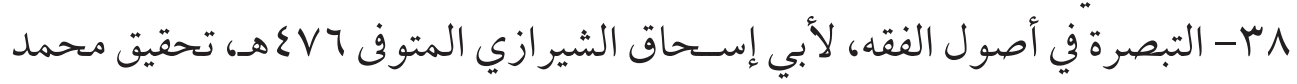

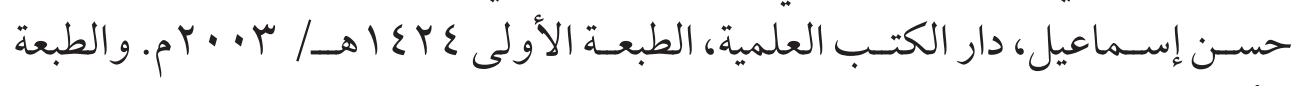

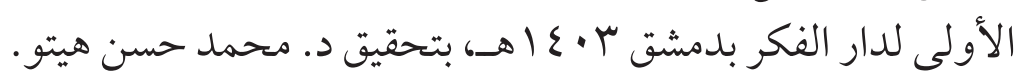

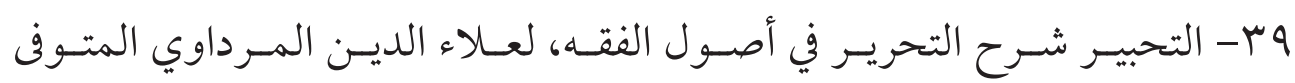

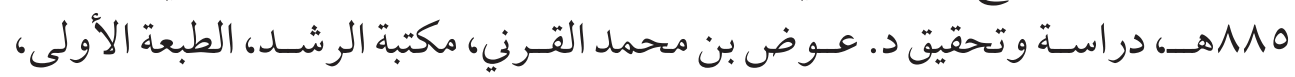

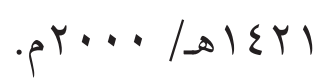

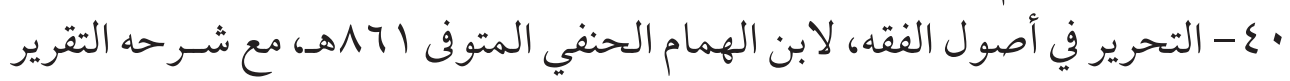

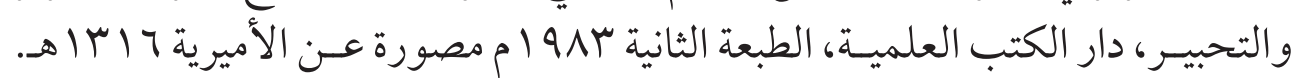

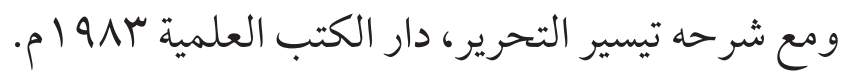

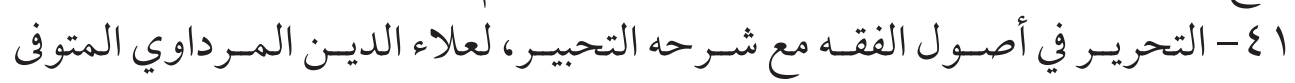

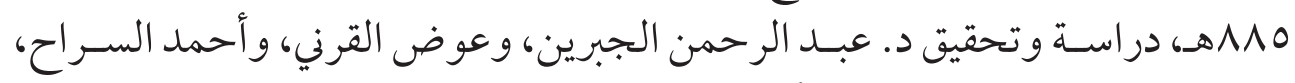

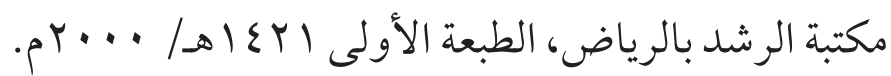

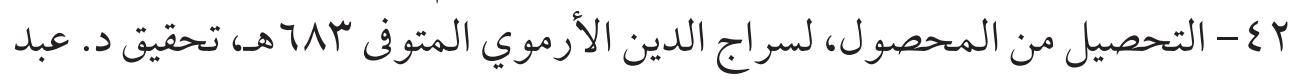

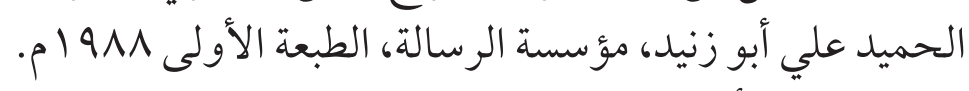

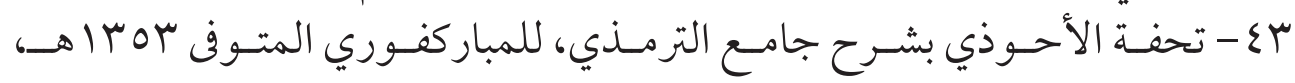

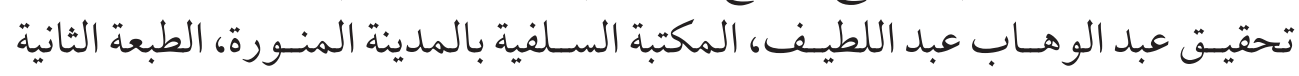

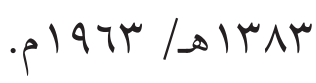
ع ع - تحفـة الطالب بمعرفة أحاديث مختصر ابن الحاجـبـ، للحافظ ابن كثير المتوفى

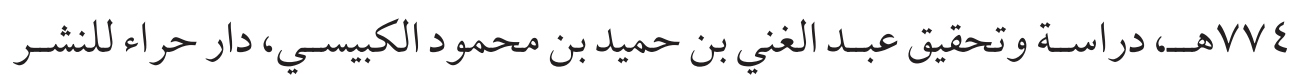

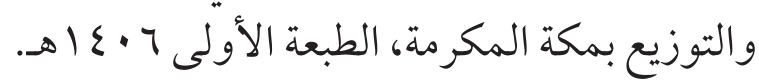




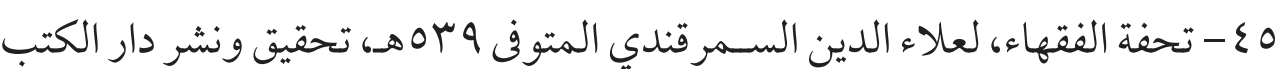

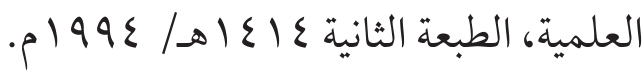

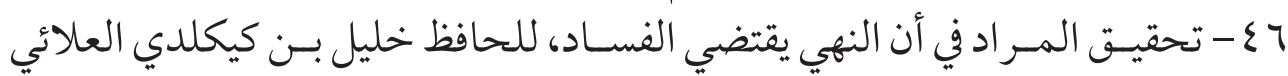

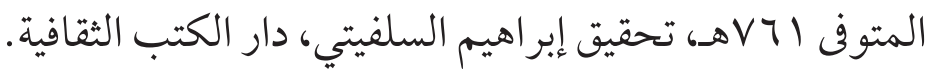

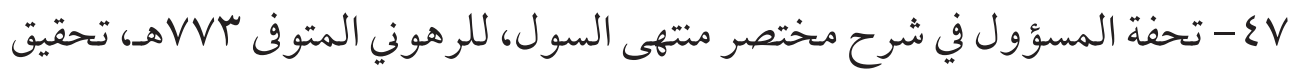

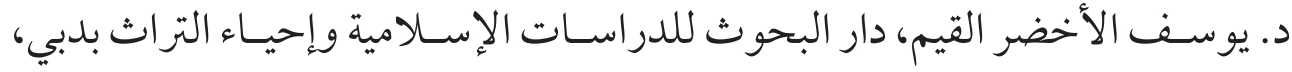

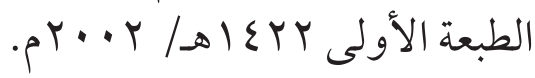

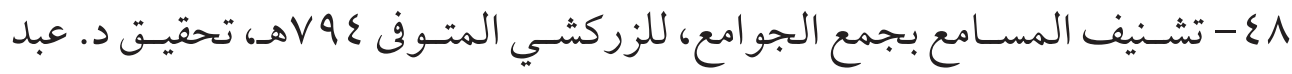

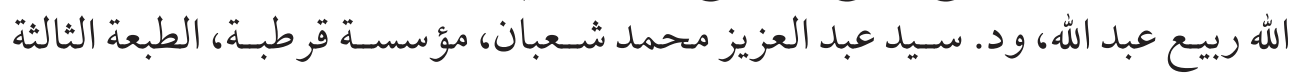

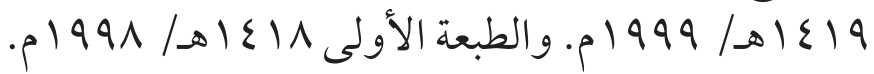

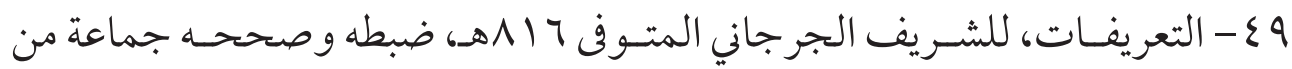

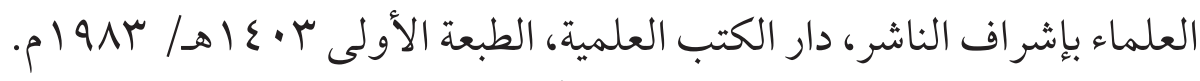

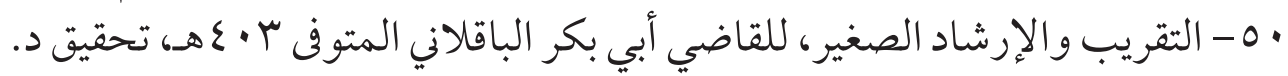

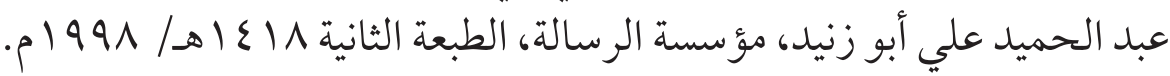

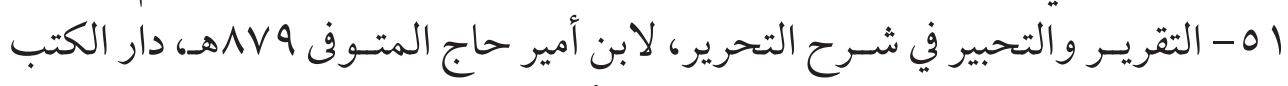

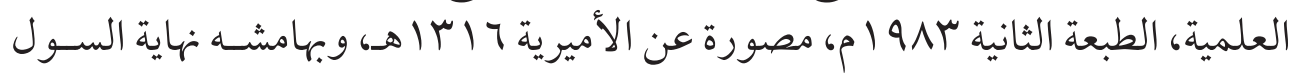
لإِسنوي.

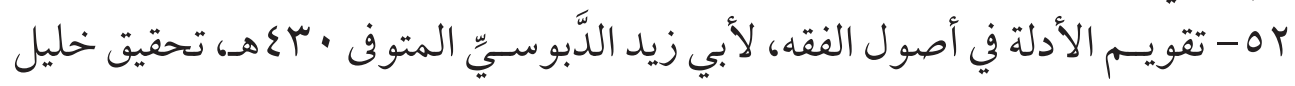

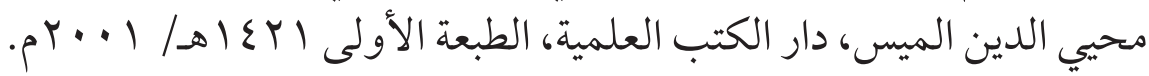

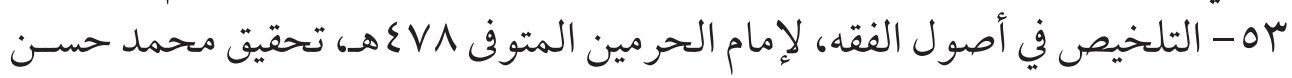

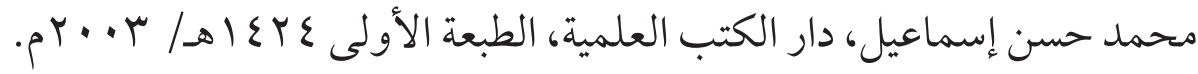

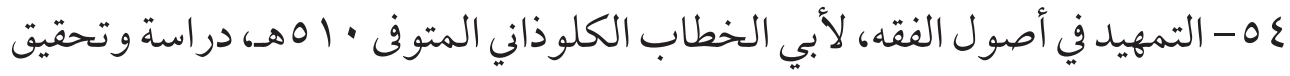

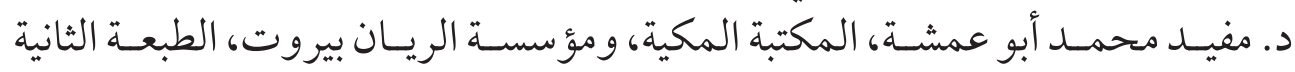

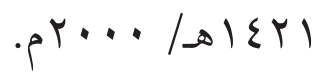

0 - التمهيـــ في تخريج الفروع على الأصول، للإمام جمال الدين الإسـنوي المتوفى VVY محمد حسن إسماعيل. 


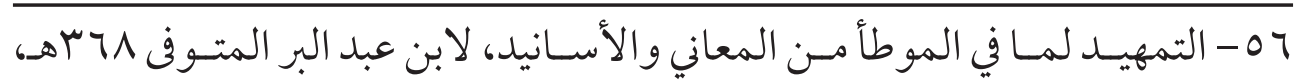

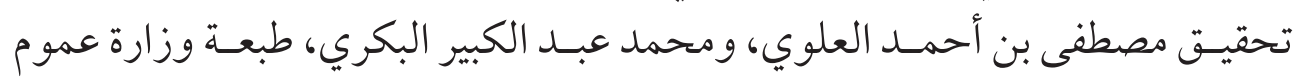

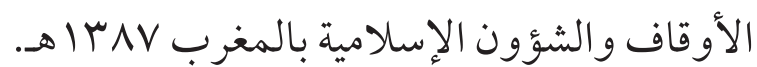
OV

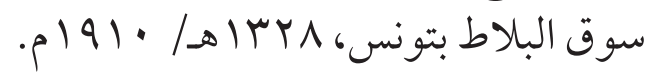

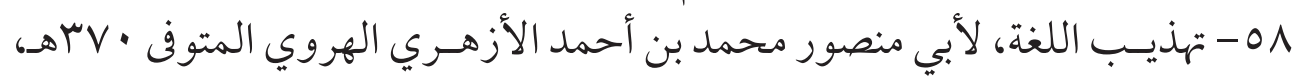

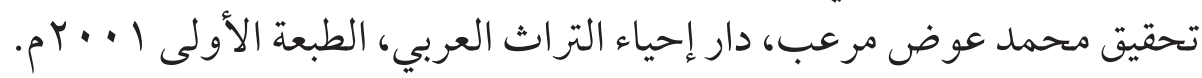

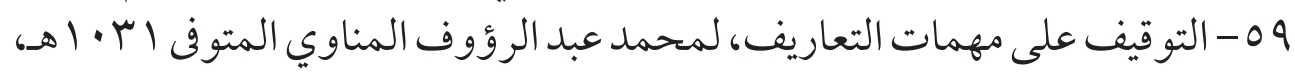

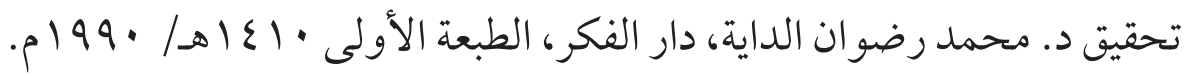

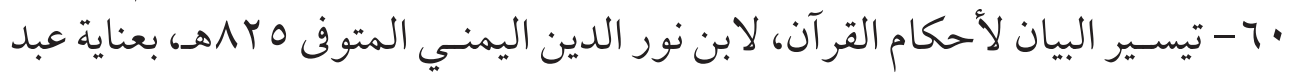

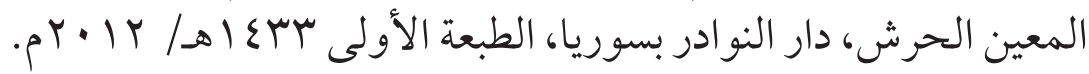

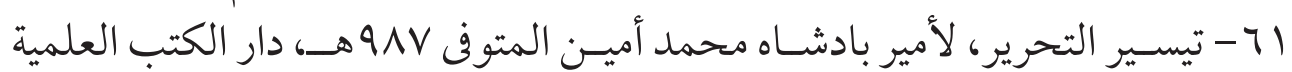
م 191 rا - تيسـير الوصول إلى منهاج الأصول من المنقول و المعقـول، لابن إمام الكاملية

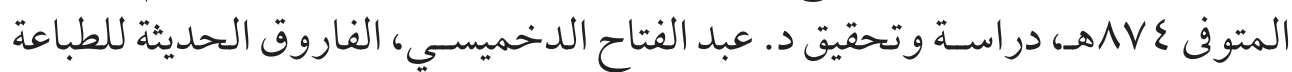

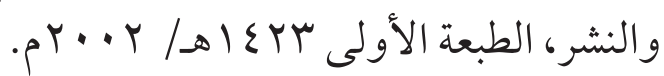

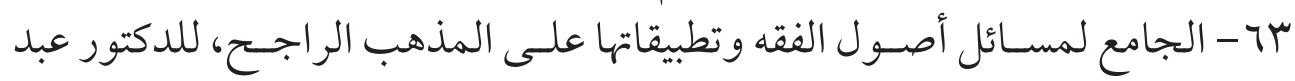

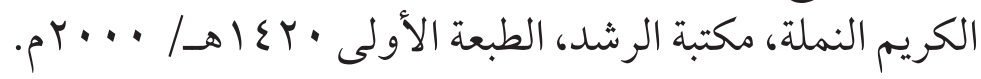

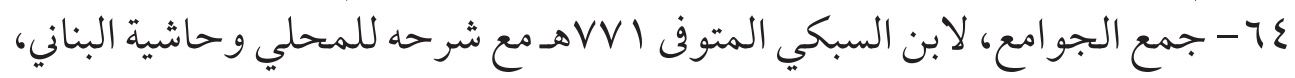
دار الفكر 1990 (1) م.

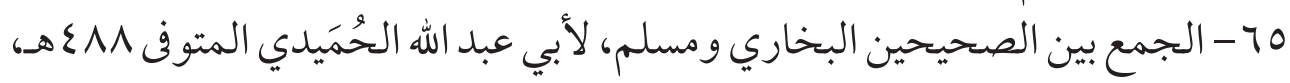

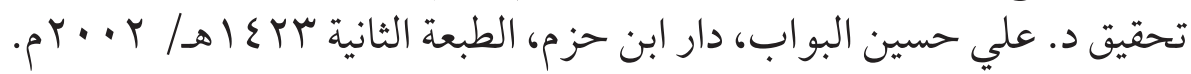

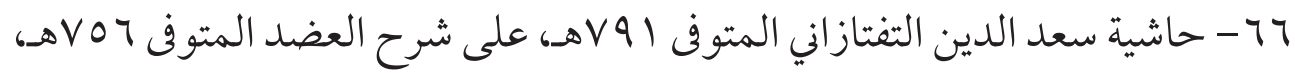

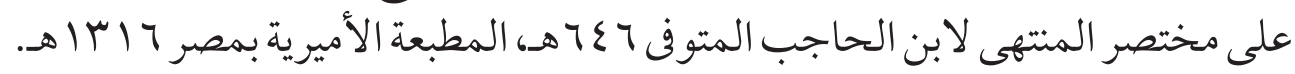
TV

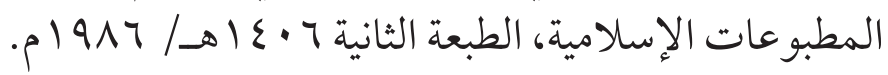


11 - حاشية النفحات على الورقات في أصول الفقه، لأحمد بن عبد اللطيف الخطيب

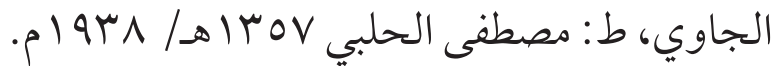

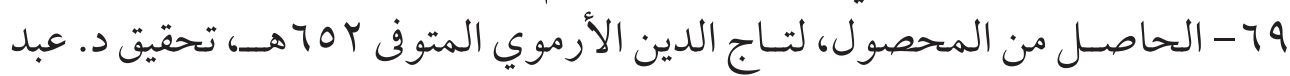

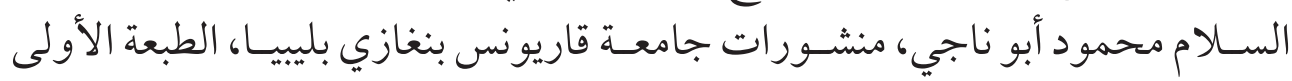
. $199 \varepsilon$ •

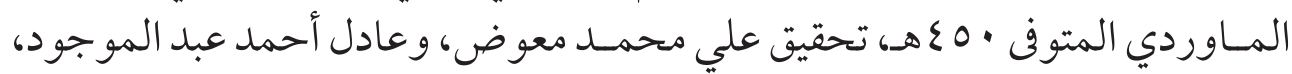

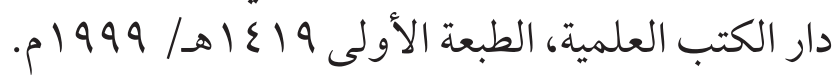

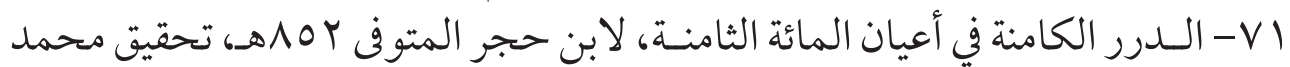

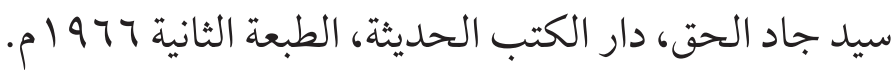

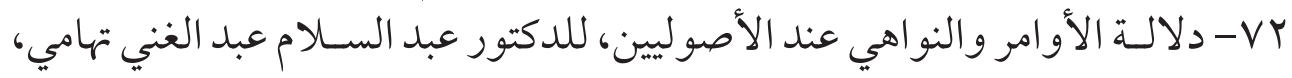

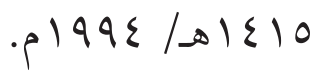

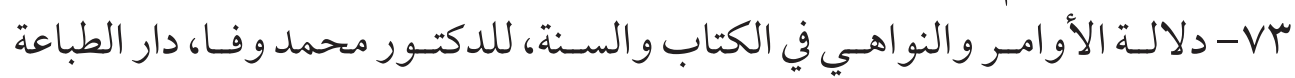

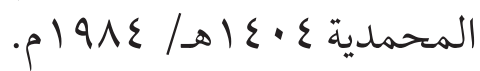

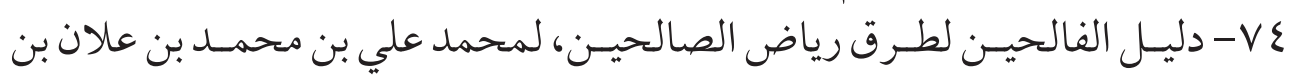

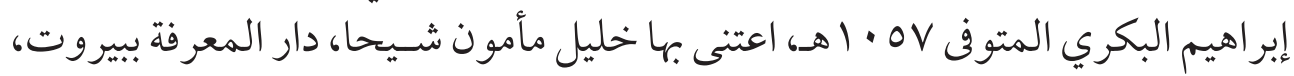

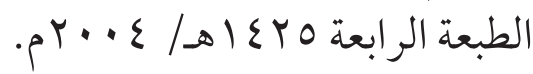

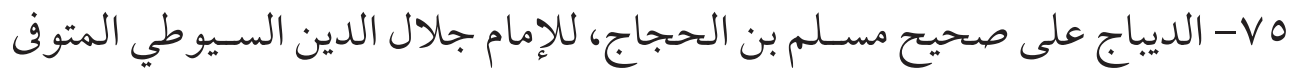

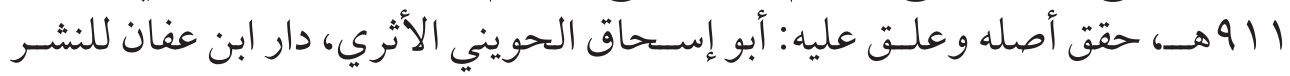

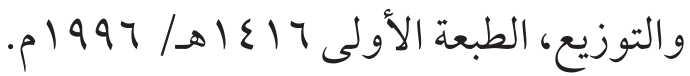

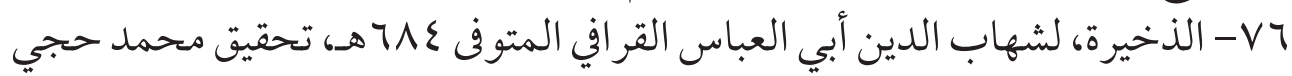

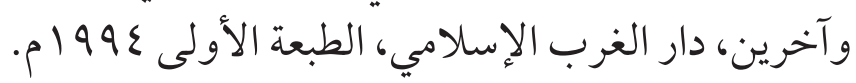

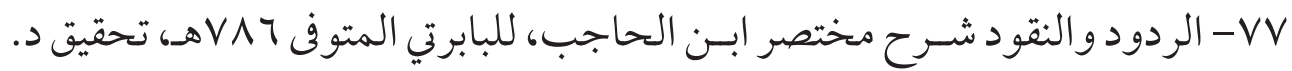

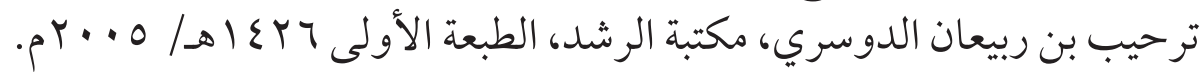

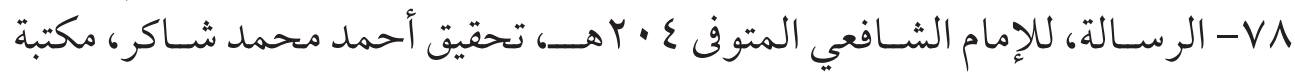

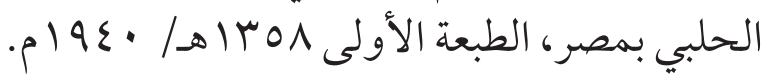


V9

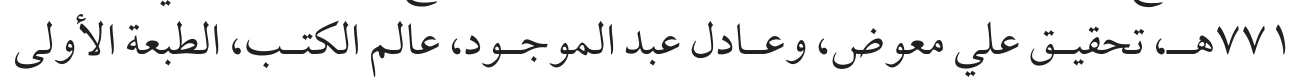

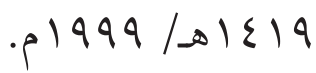
• م- رفع النقاب عن تنقيح الشهاب، لأبي علي حسين بن علي الرجر اجي الشوشاوي

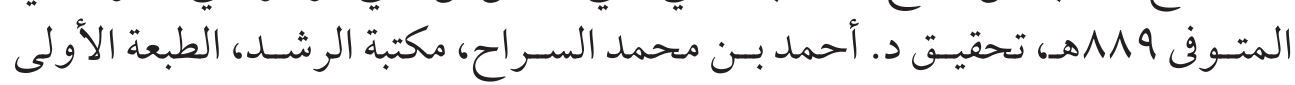

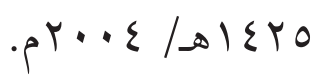

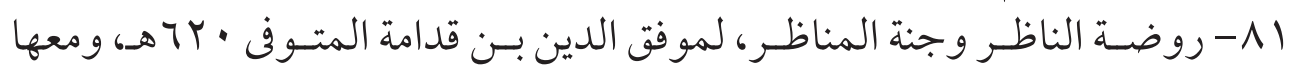

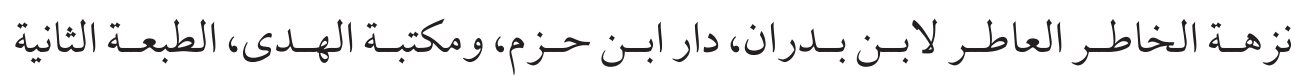

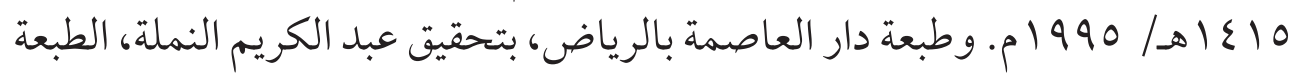

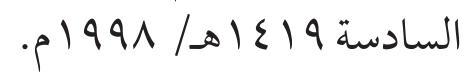

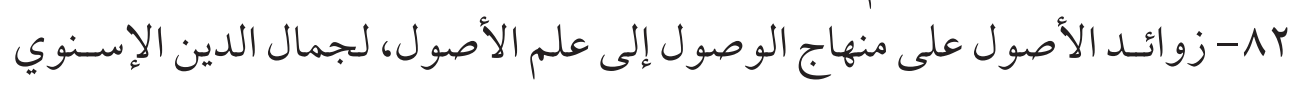

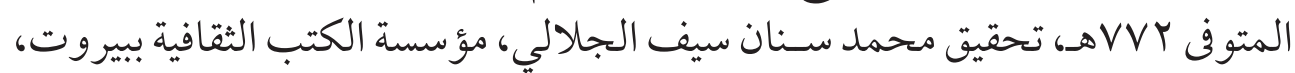

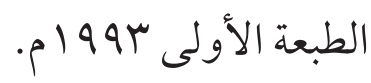

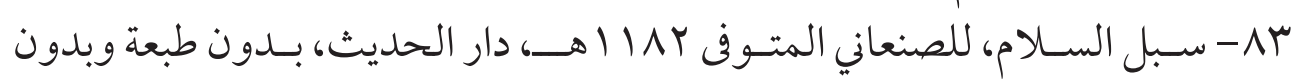
تاريخ. ع - - سنن الترمذي "الجامع الصحيح"، لأبي عيسى محمد بن عيسى بن سورة المتوفى PV9

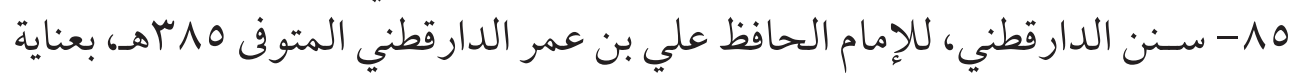

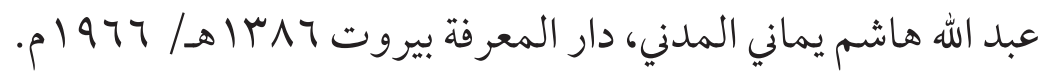

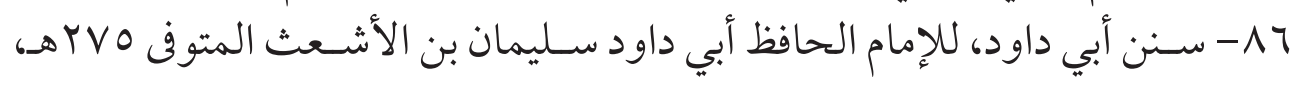

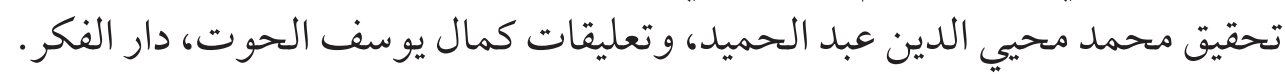
NV

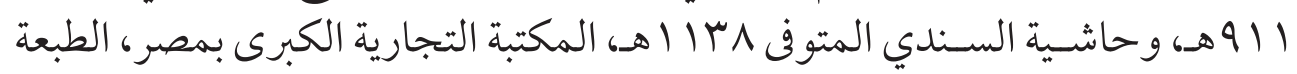

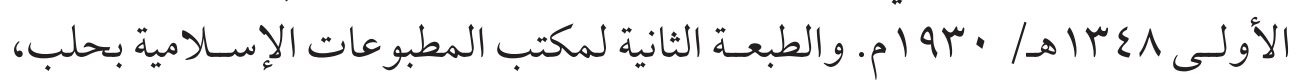

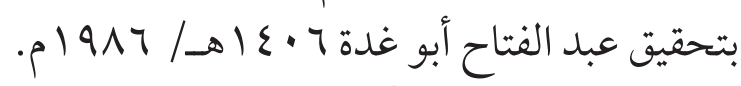

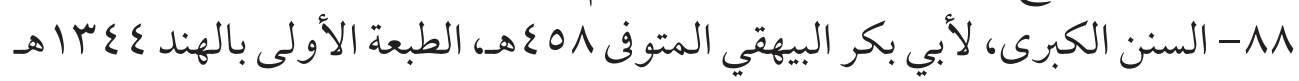

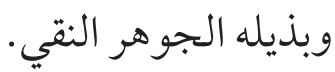




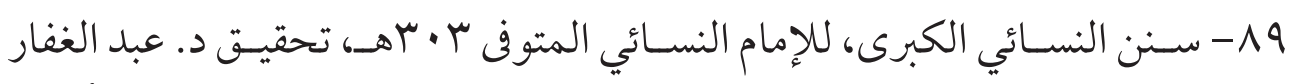

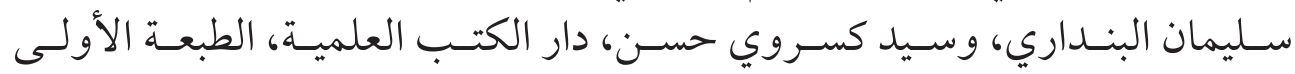

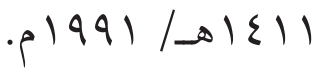

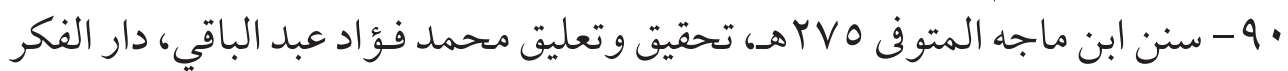
بيروت.

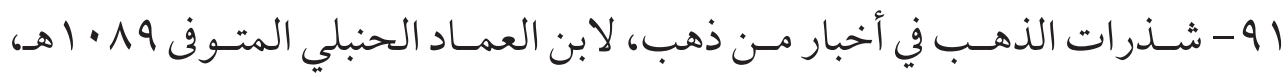
المكتب التجاري للطباعة والنشر والتوزيع بيروت.

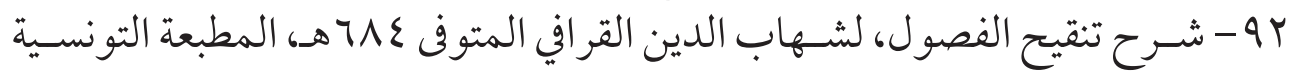

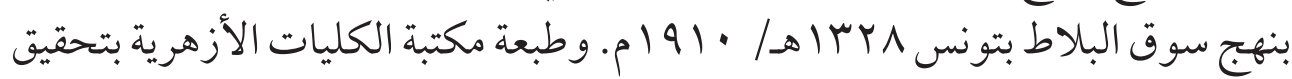

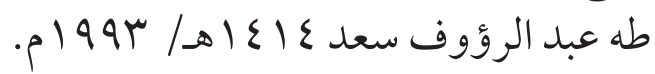
بو - شـرح تنقيح الفصول، للشيخ حلولو المتوفى بعد 190هـ، المطبعة التونسية بنهج

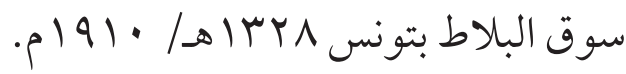

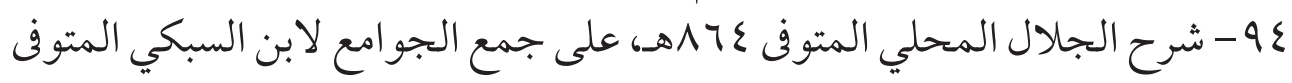
PVI

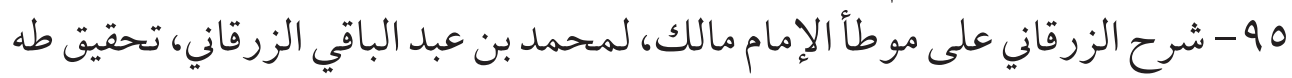

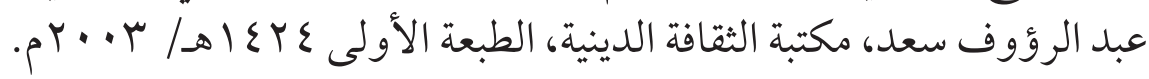

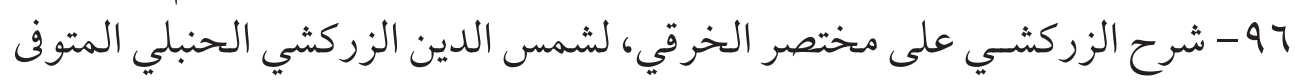

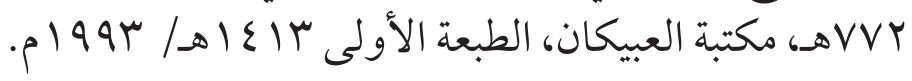

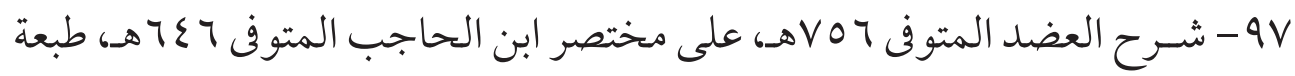

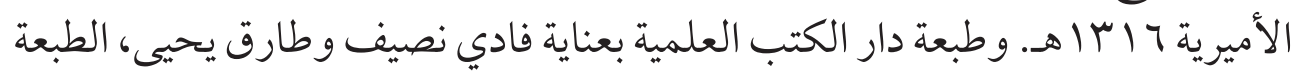

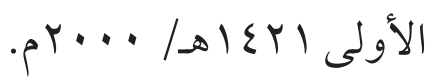

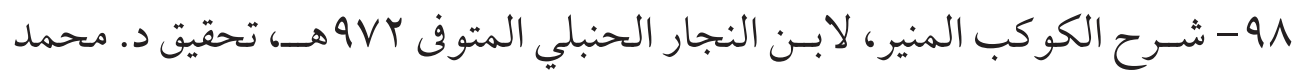

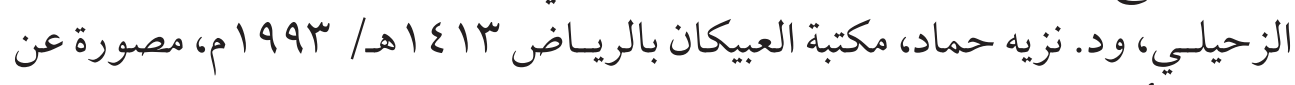

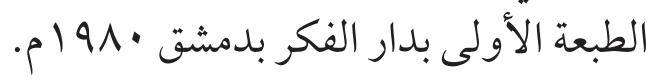

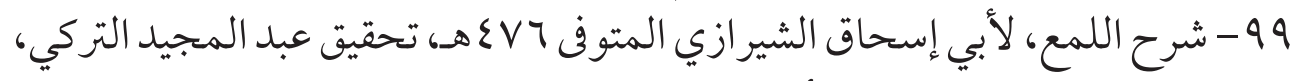

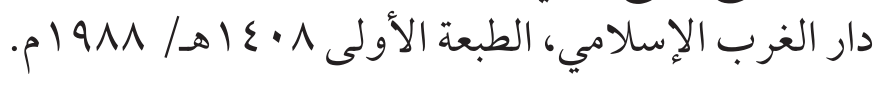




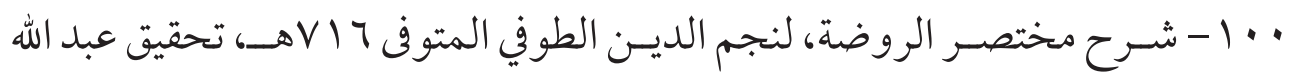

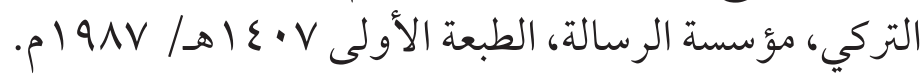

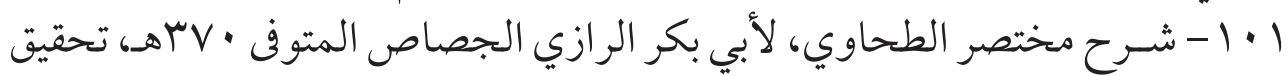

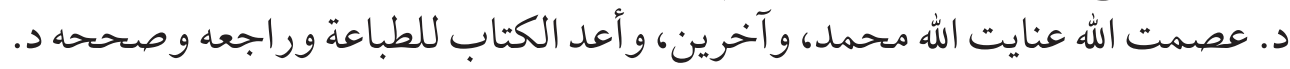

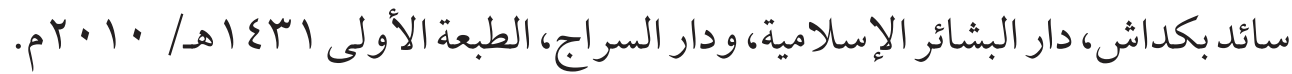

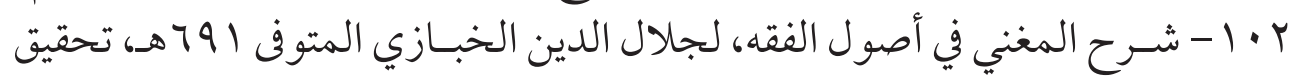

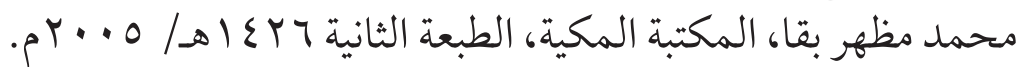

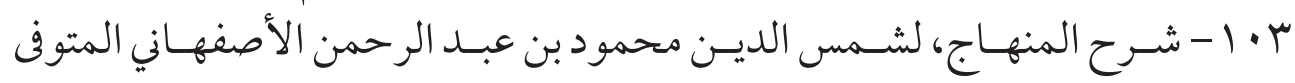

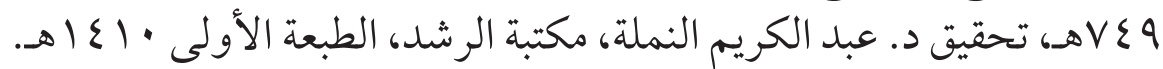

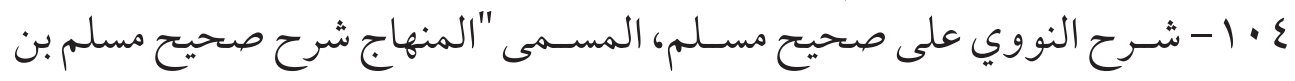

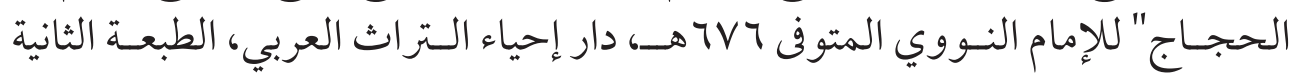
r ras

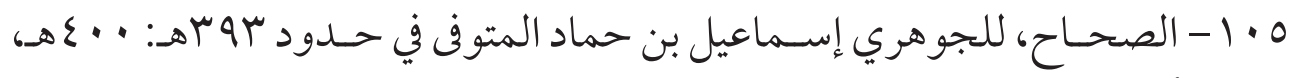

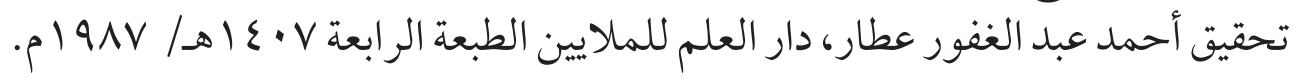

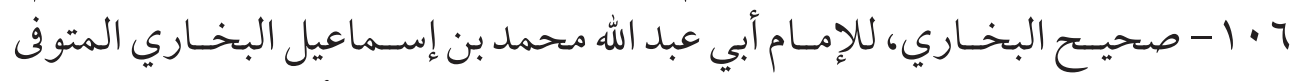

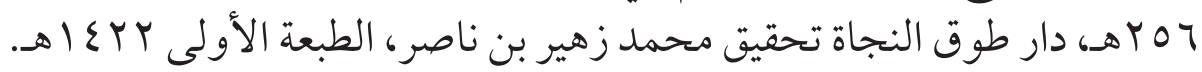

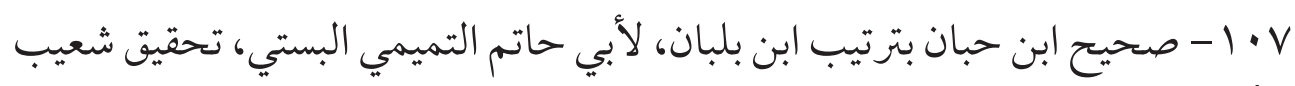

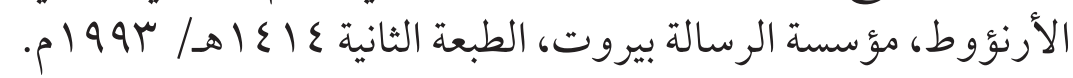

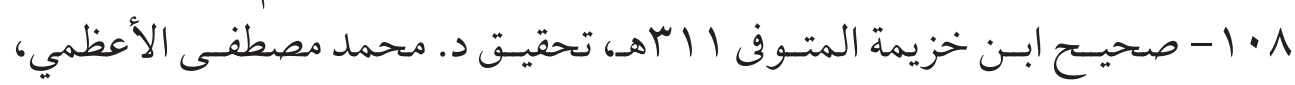

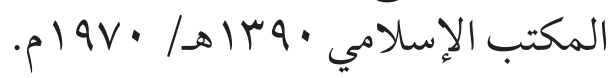

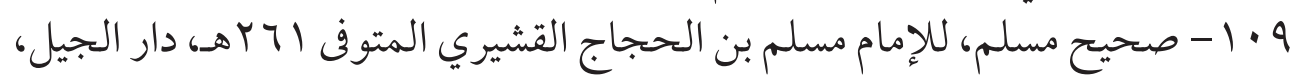
ودار الآفاق الجديدة.

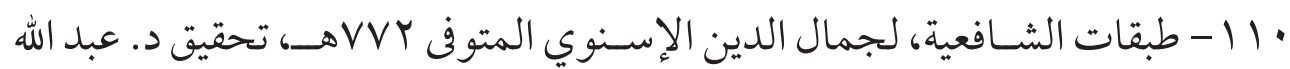

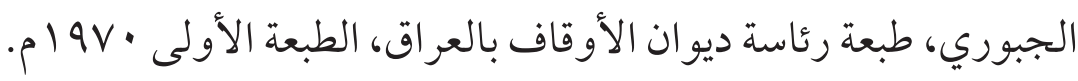

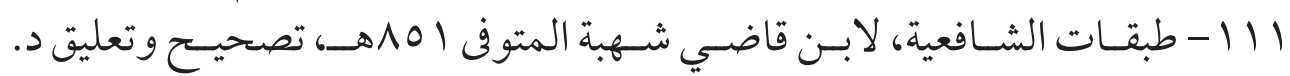

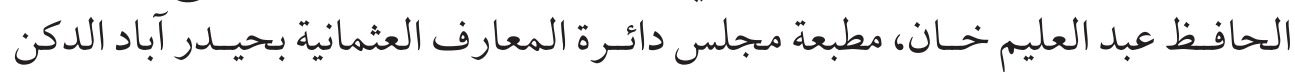

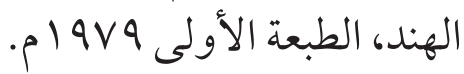




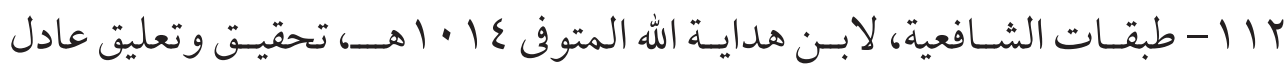

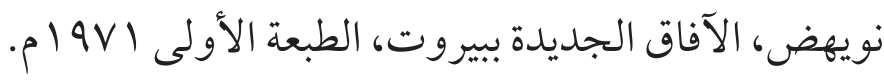

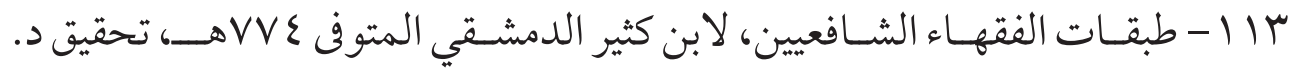
أحمد عمر هاشم، ود. محمد زينهم محمد عزب، مكتبة الثقافة الدينية سو 99 أم.

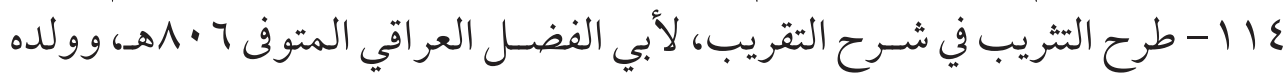

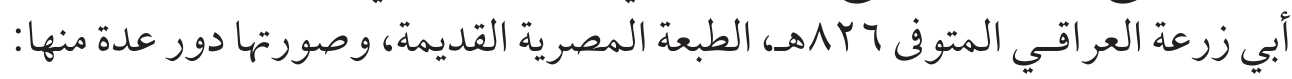

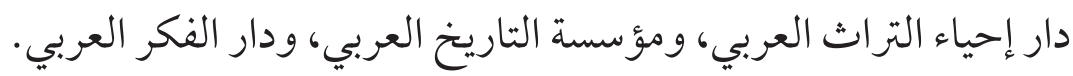

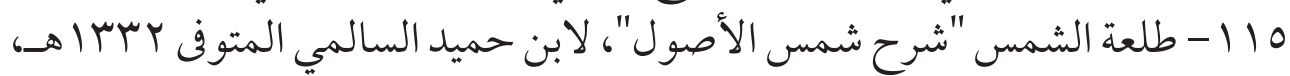

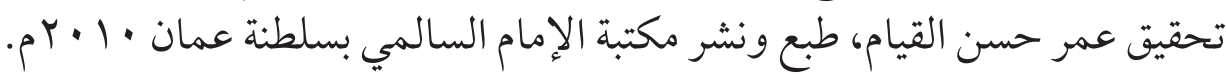

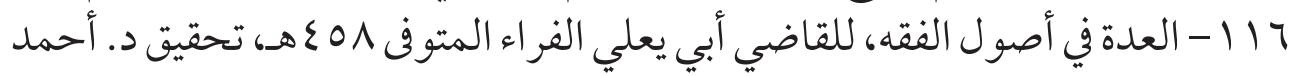

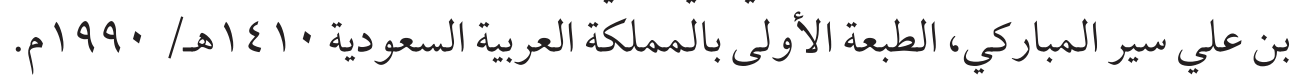

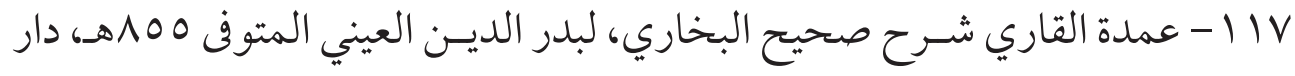

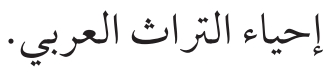

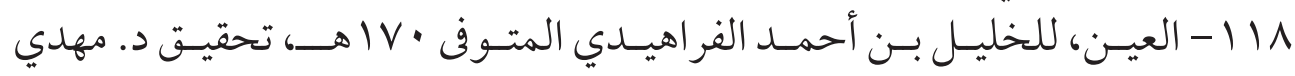

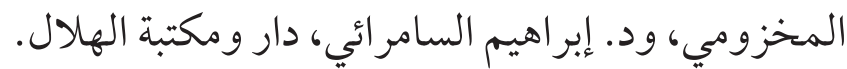

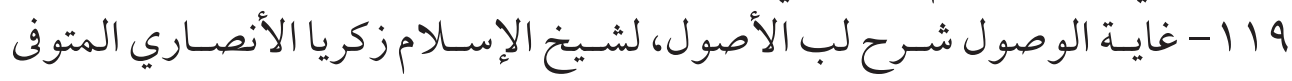

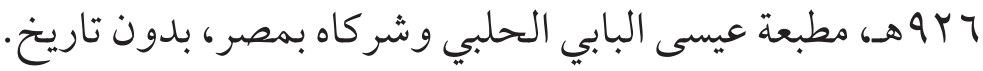

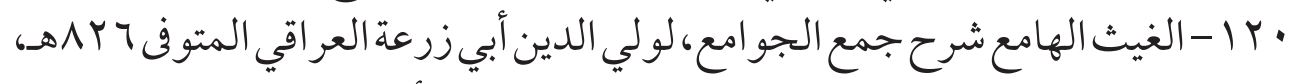

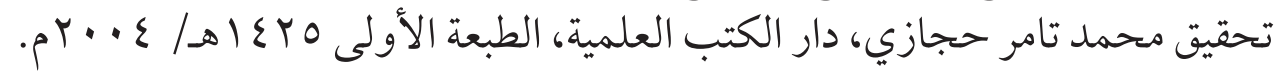

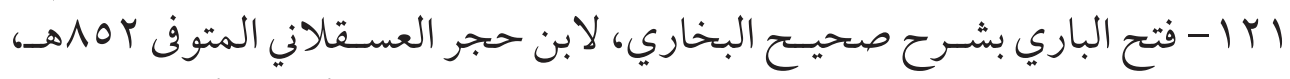

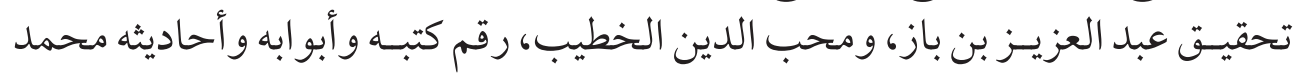

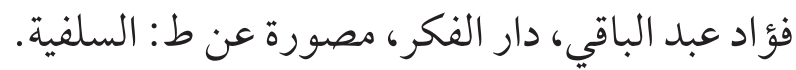

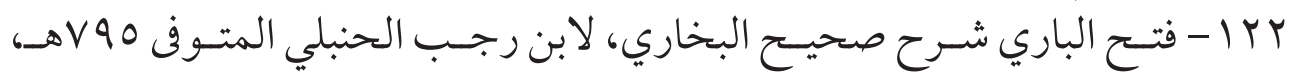

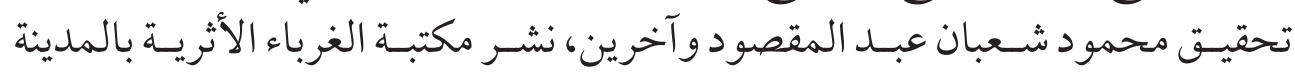

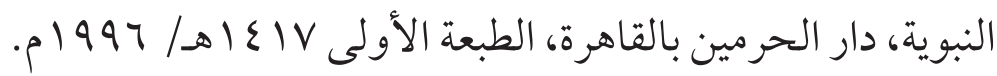

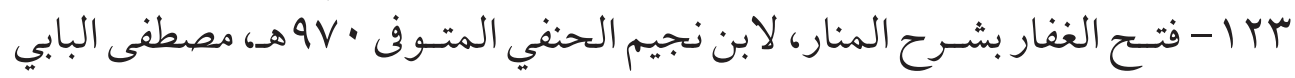

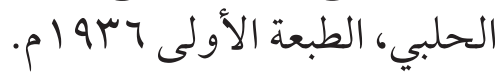


ع ا I - الفصـول في الأصول، لأبي بكر الرازي الجصـاص المتوفى · VIهـ، تحقيق د.

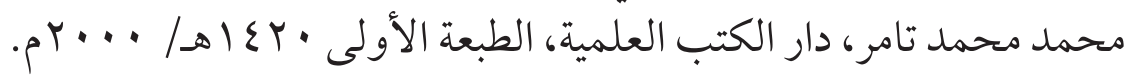

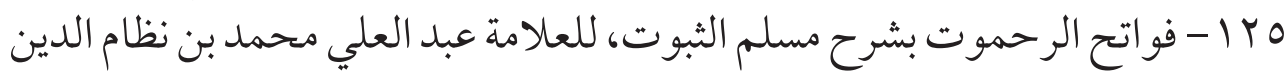

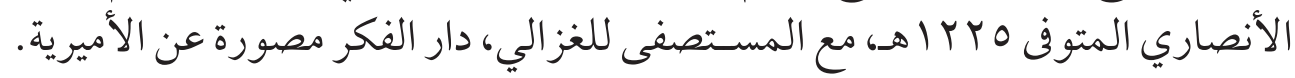

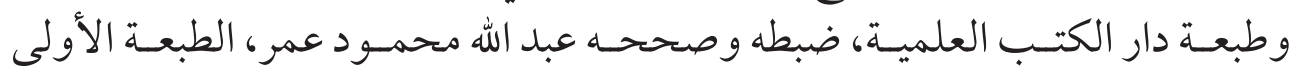
r

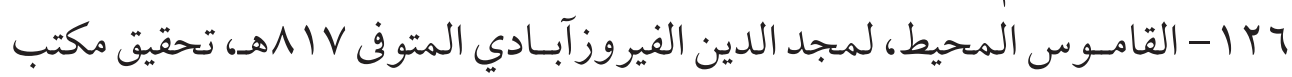

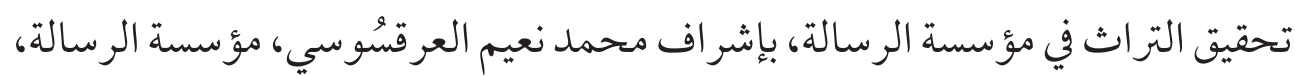

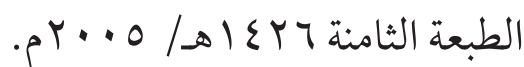

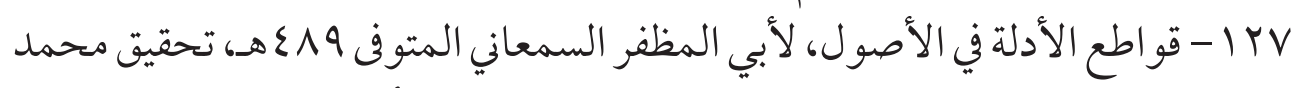

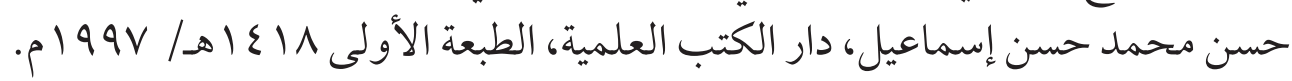

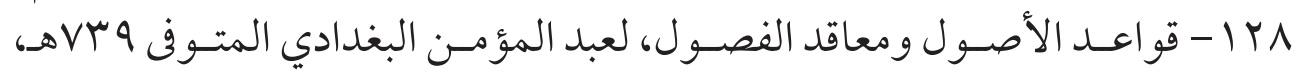

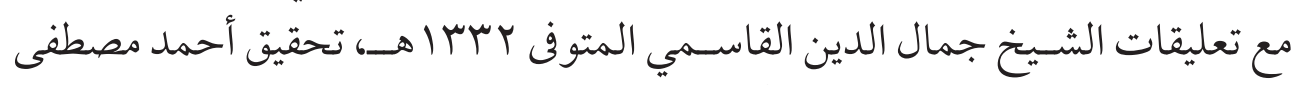
الطهطاوي، دار الفضيلة، الطبعة الأولى 99 ألى م.

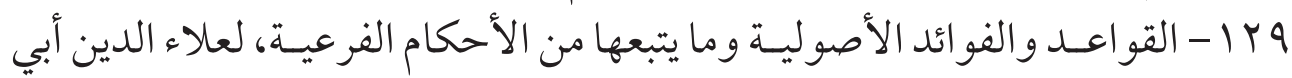

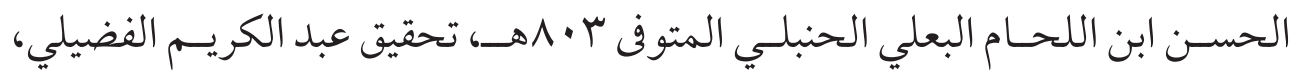

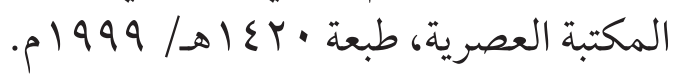

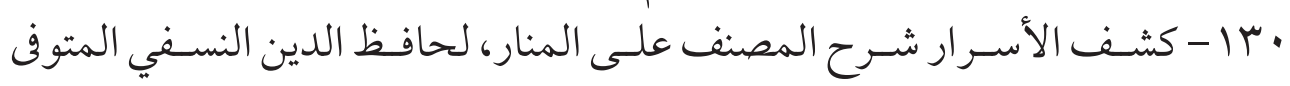

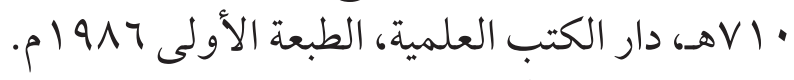

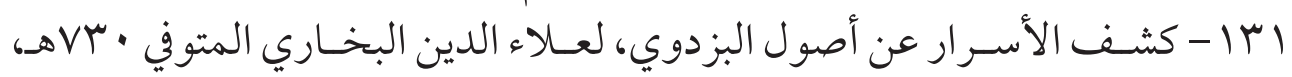

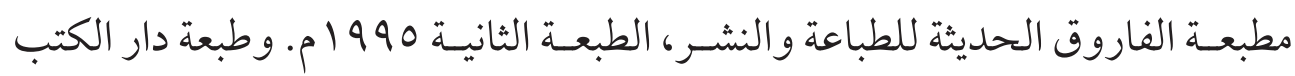

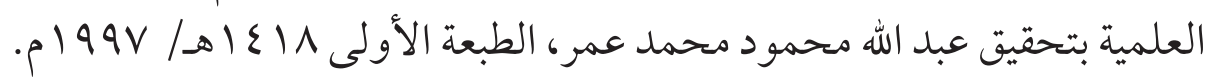

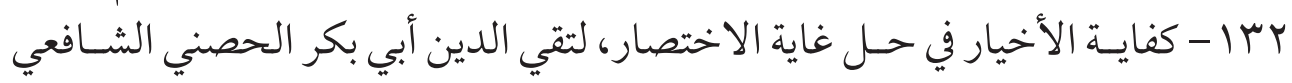

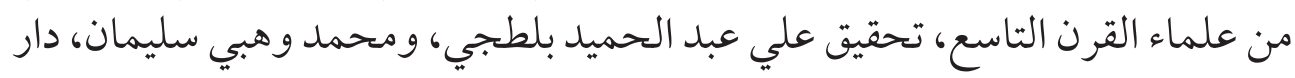

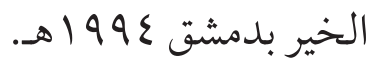

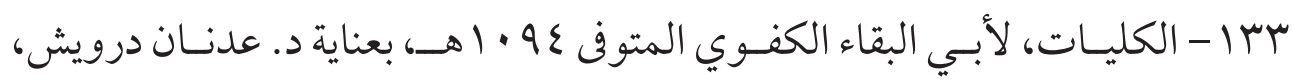

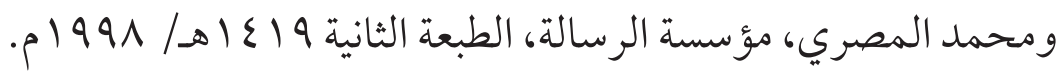


ع با - لب الأصول مع شـرحه غاية الوصول، لشيخ الإسلام زكريا الأنصاري المتوفى

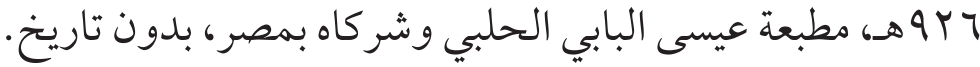

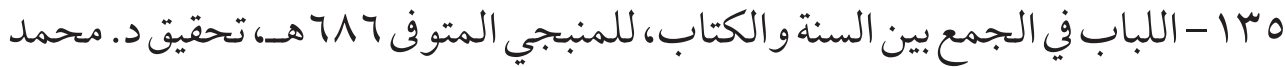

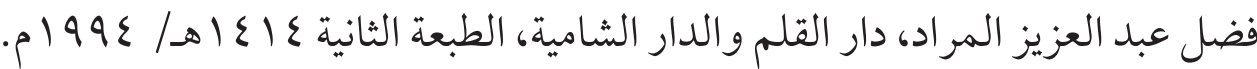

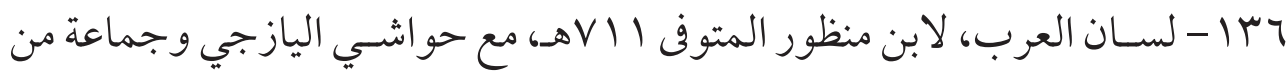
اللغويين، دار صادر، الطبعة الأولى.

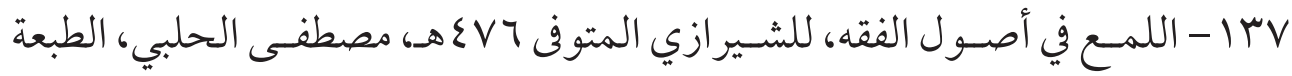
الثالثة

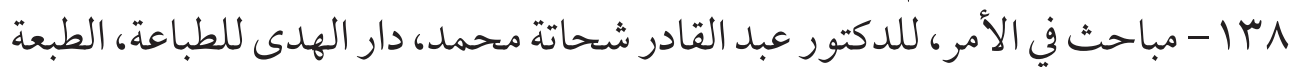

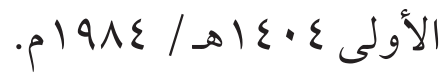

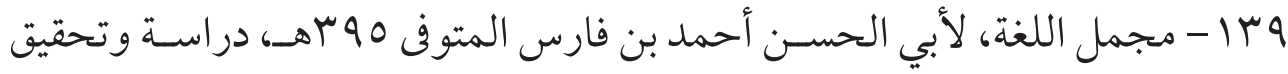

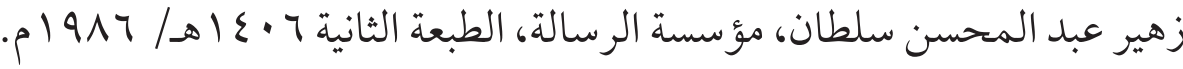

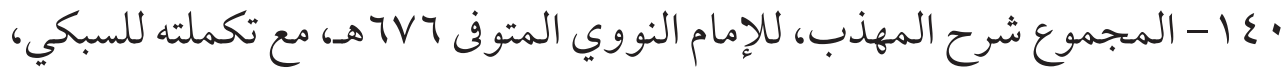
و المطيعي، دار الفكر. اع ا - محاضرات في أصول الفقه للفرقة الثانية بكلية الدراسـات الإسلامية والعربية، الفصل الأول الخاص بالأوامر و النواهي، للدكتور السـيد عبد اللطيف كسـاب، بدون

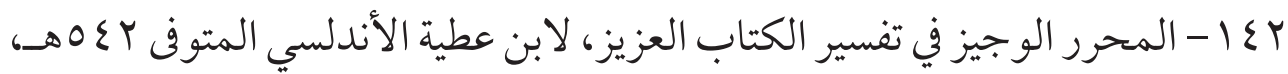

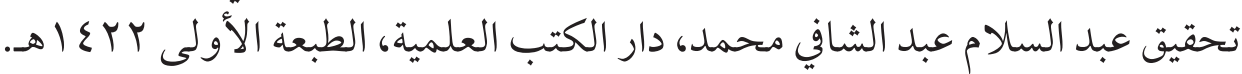

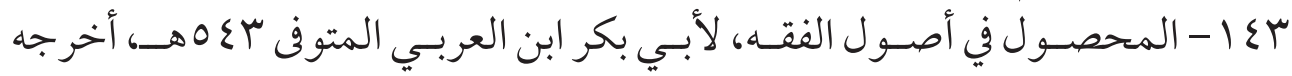

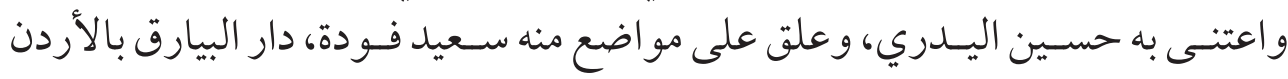

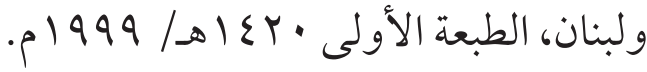

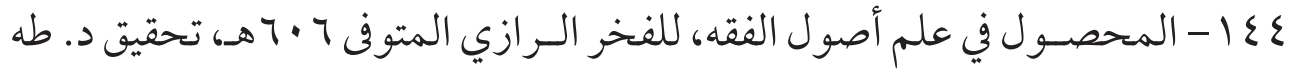

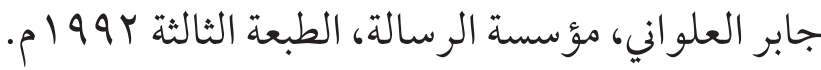

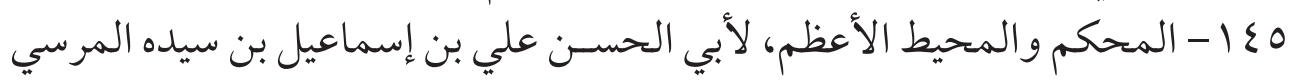

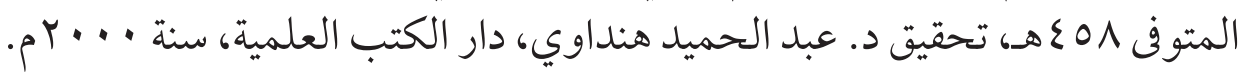

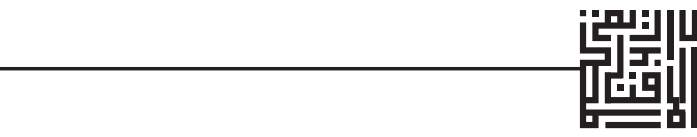




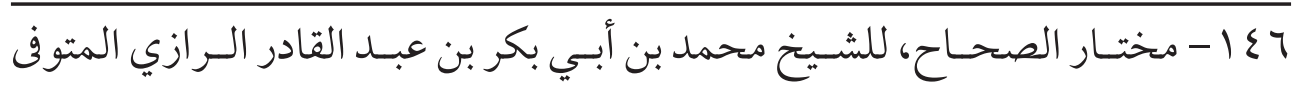

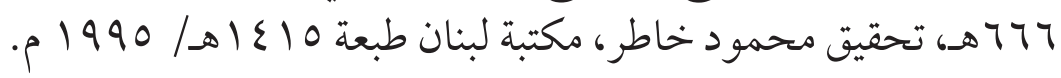

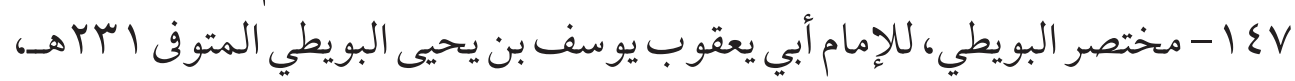

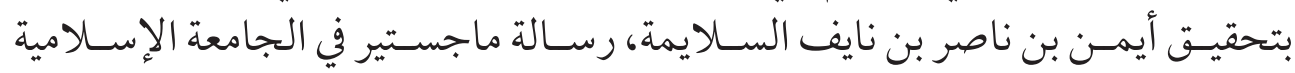

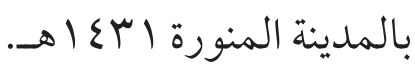

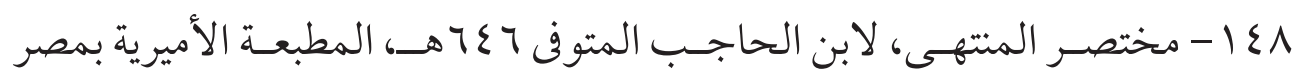
7 ا Mا هـ و معه شرح العضد، وحور اشي السعد و الجر جاني.

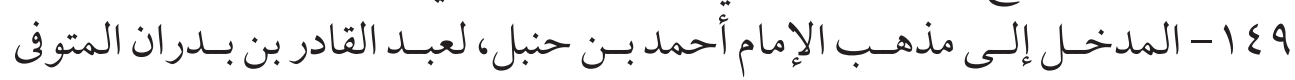

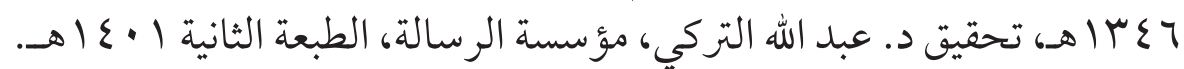

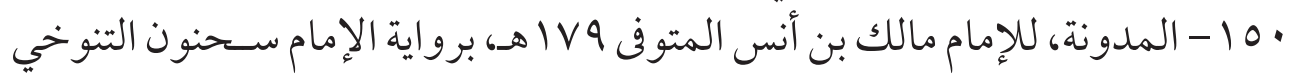

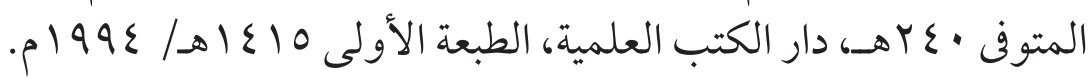

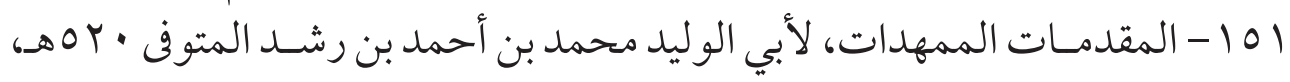

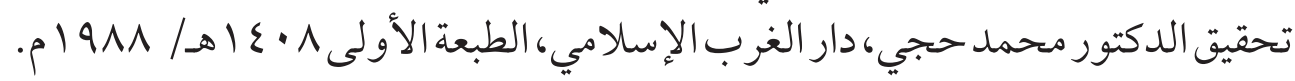

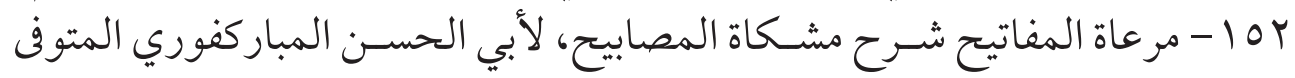

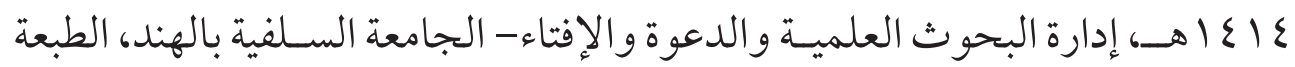

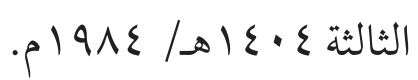

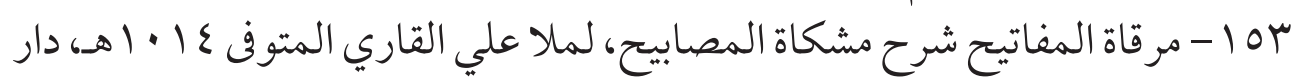

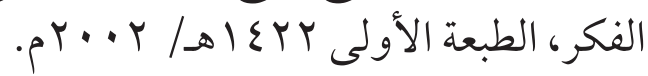

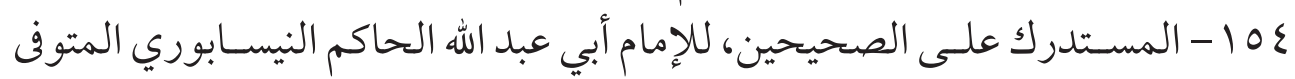

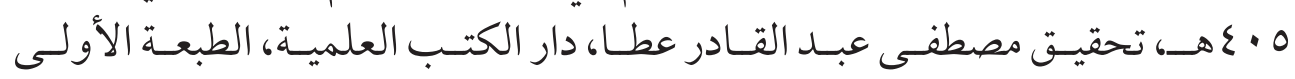

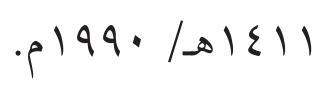

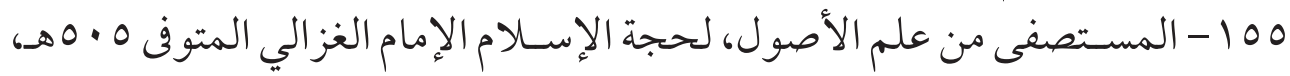

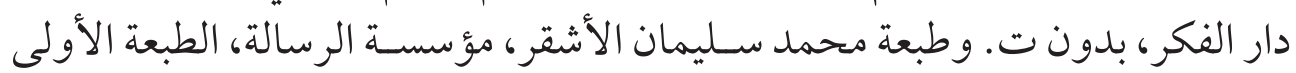
. $199 \mathrm{~V} / 1 \leqslant 1 \mathrm{~V}$

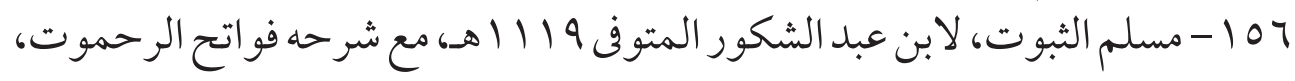
دار الفكر، بدون ت مسبم التوت

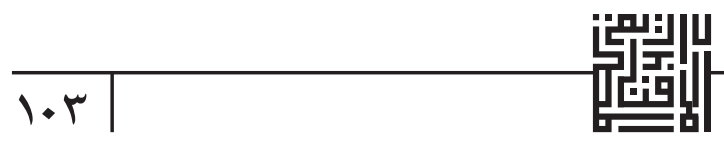




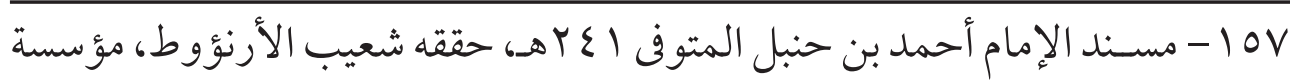

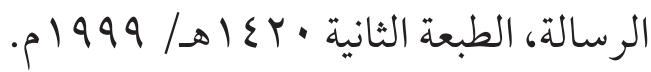

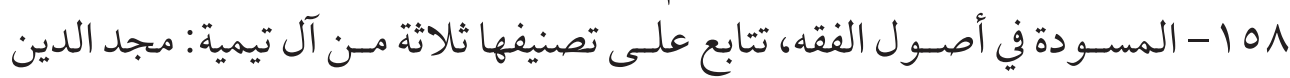

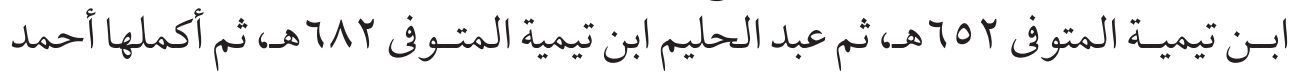

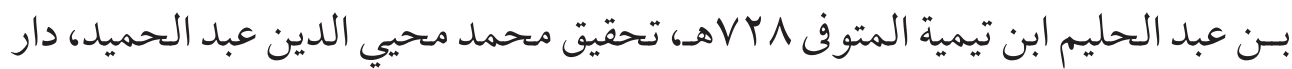

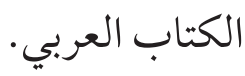

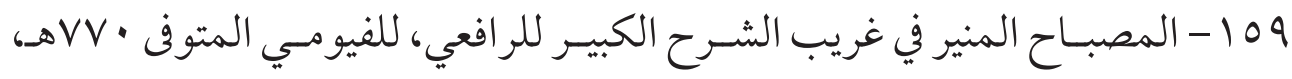
دراسة وتحقيق يوسف الشيخ محمد، المكتبة العصرية.

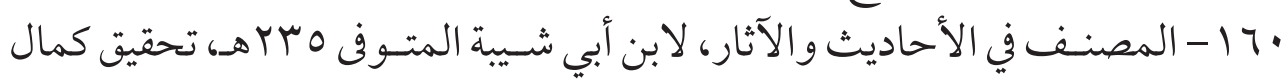

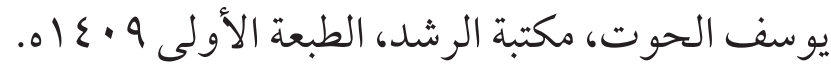

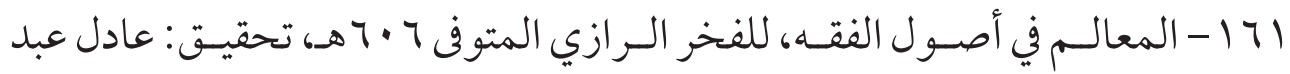

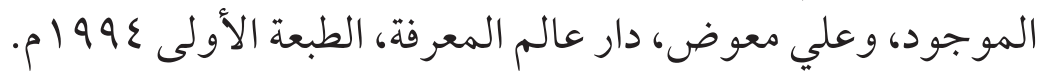

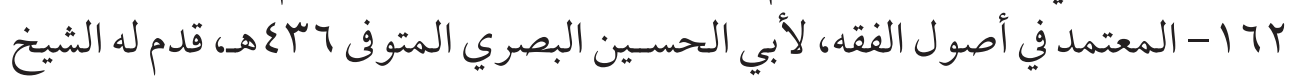
خليل الميس، دار الكتب العلمية، بدون تاريخ.

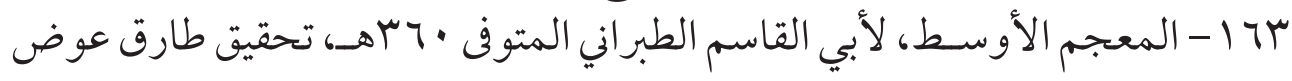
الله، وعبد المحسن الحسيني، دار الحرمين بالقاهرة.

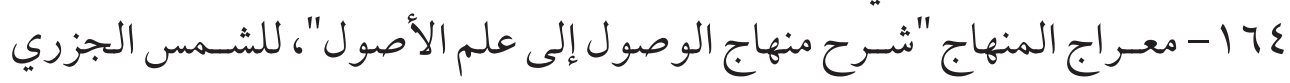

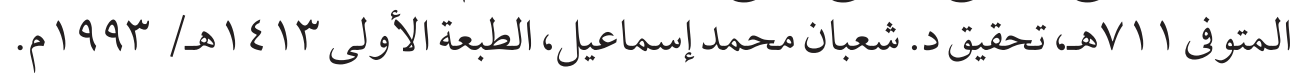
70 ا 10

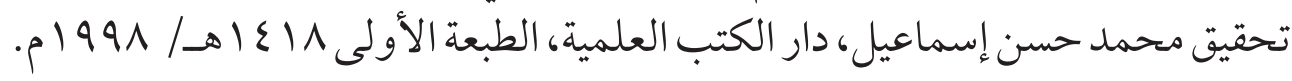

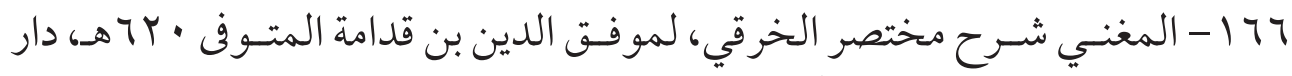

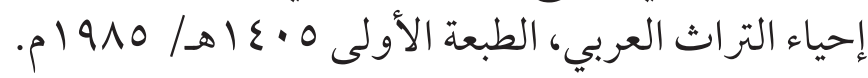

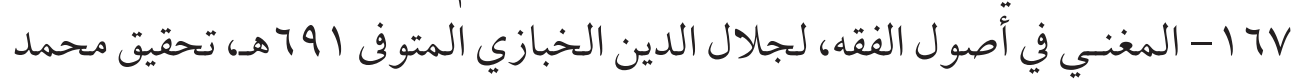

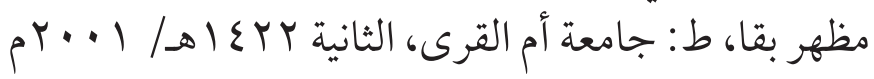

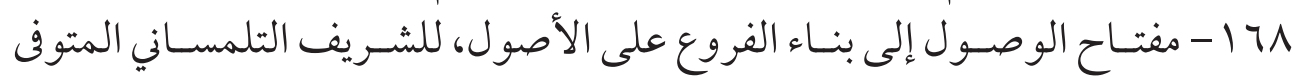

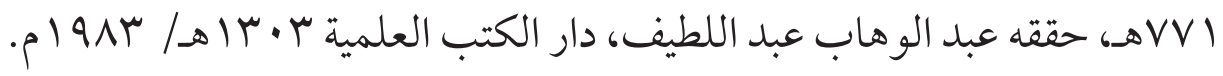

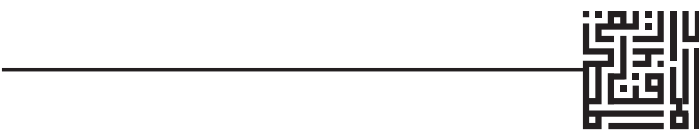


19 ا - منـار القـاري شـرح مختصر صحيح البخـاري، لحمزة محمد قاسـم، راجعه:

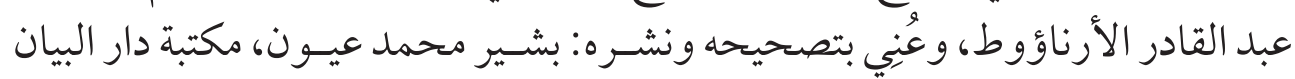

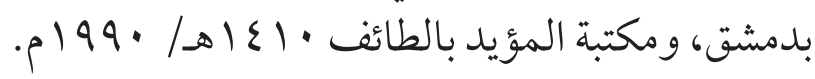

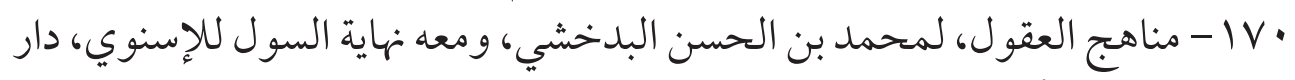

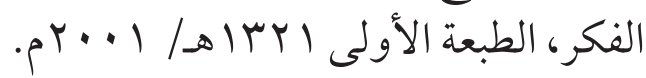

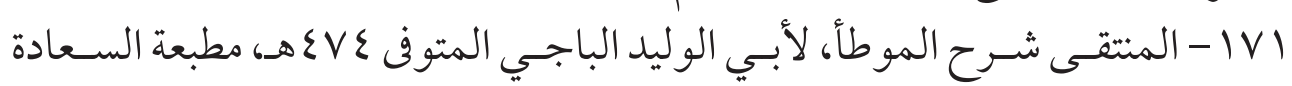

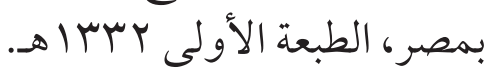

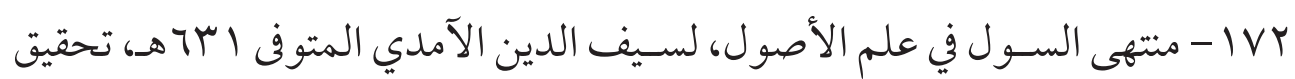

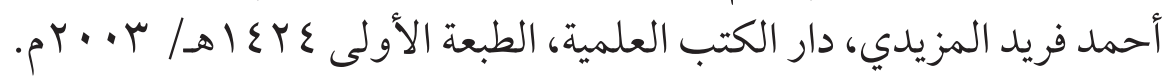

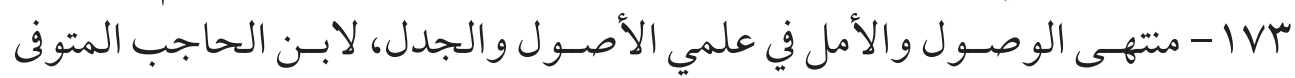

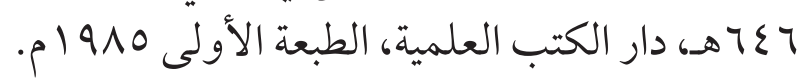

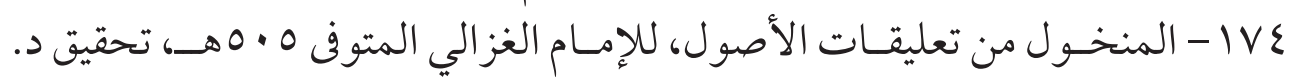

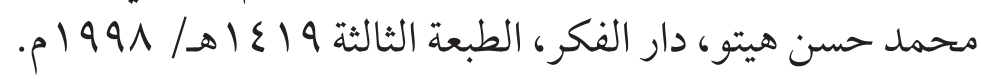

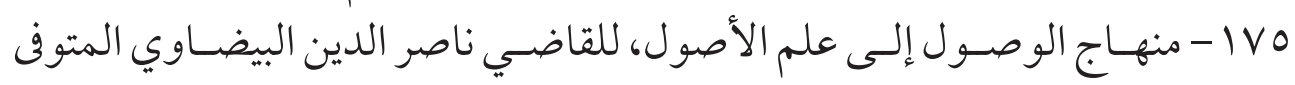

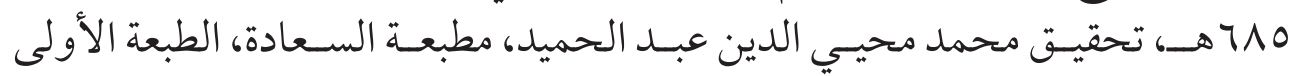
- 1901

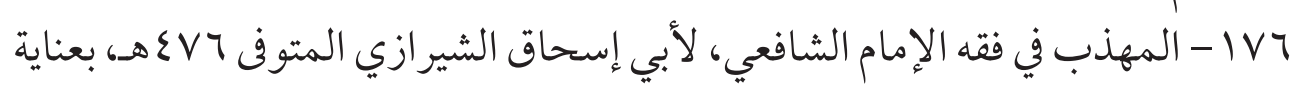
الشيخ زكريا عميرات، دار الكتب العلمية.

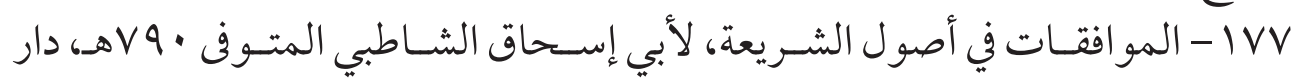

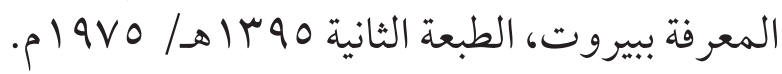
IVA

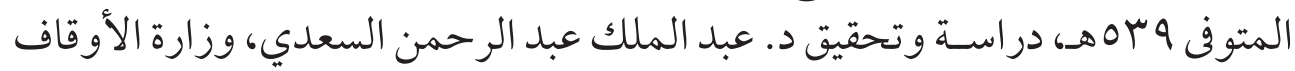

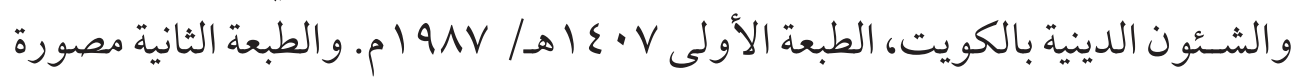
عن الأولى 99 1 19 م بمكتبة دار التراث الت بالقاهرة.

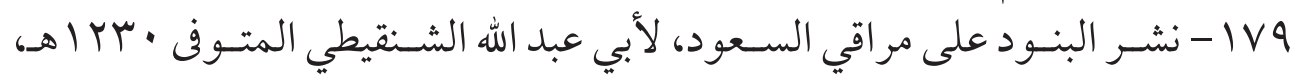

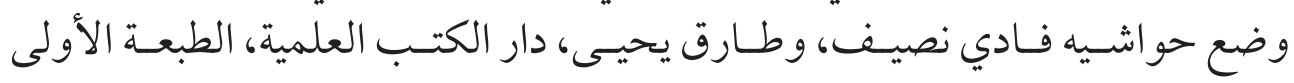

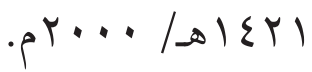




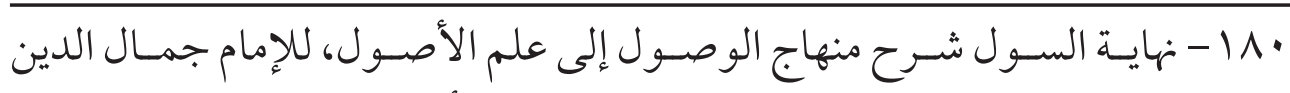

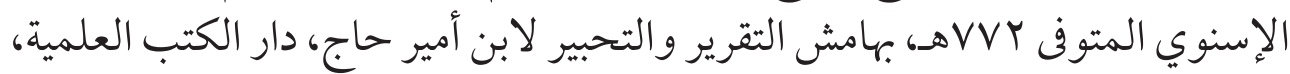

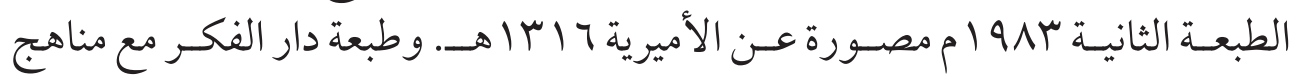
العقول للبدخشي.

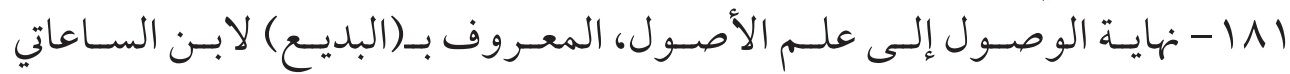

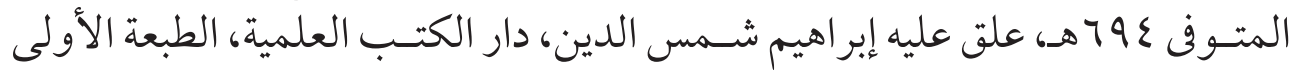

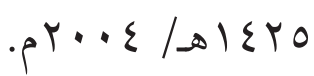

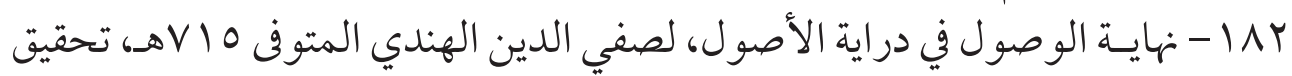

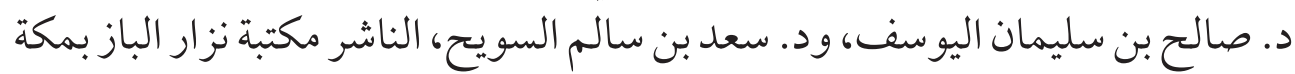

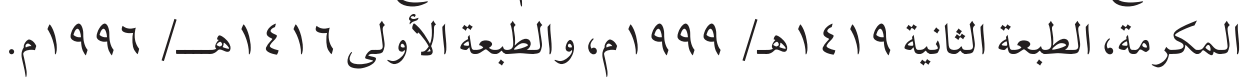

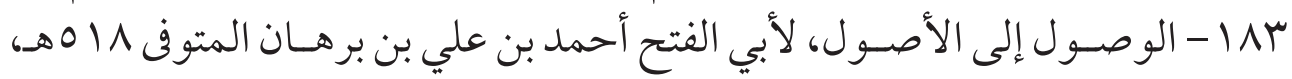

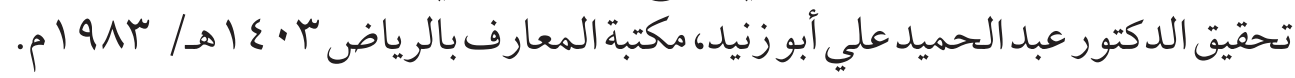

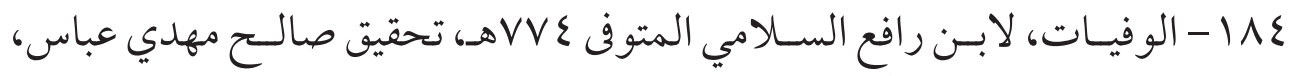

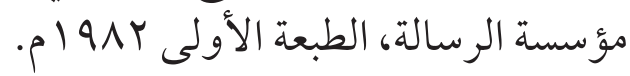

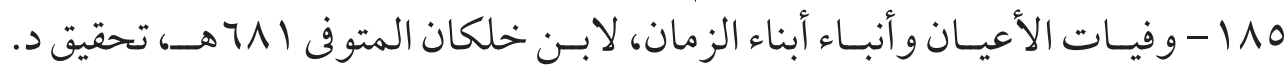
إحسان عباس، دار صادر بيروت، بدون تاريخ.
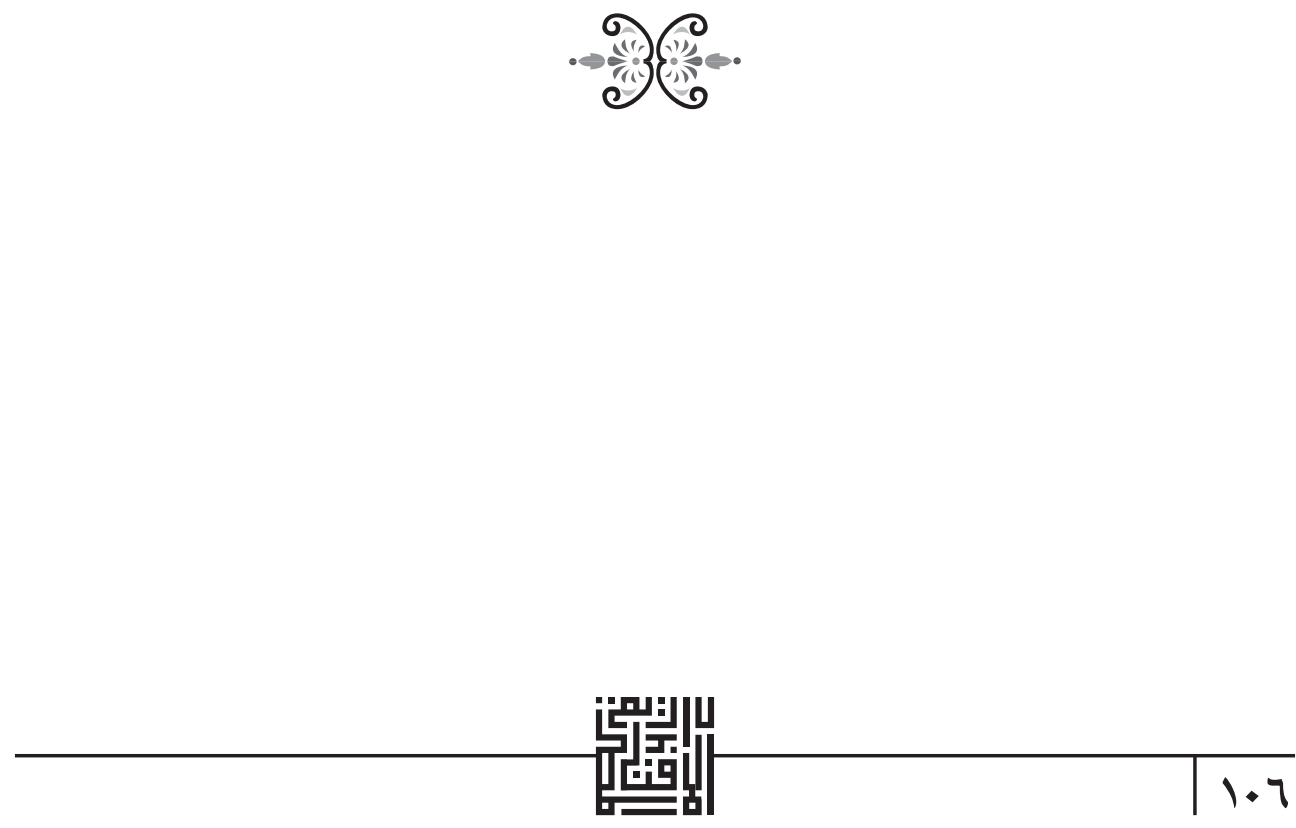


\section{فهرس المحتويات}

المسألة السابعة: ما يدل عليه النهي المطلق من المرة أو التكرار، والفور أو

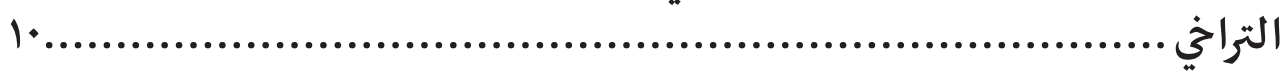

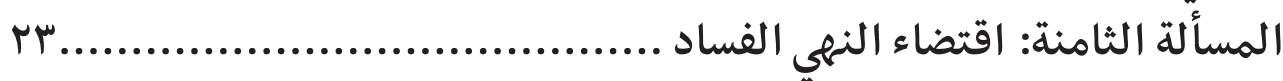

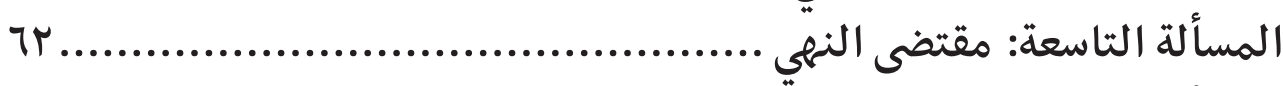

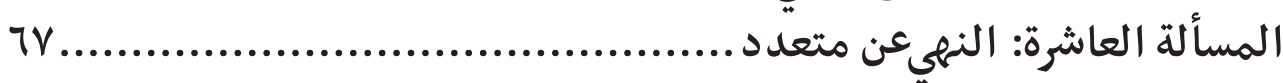

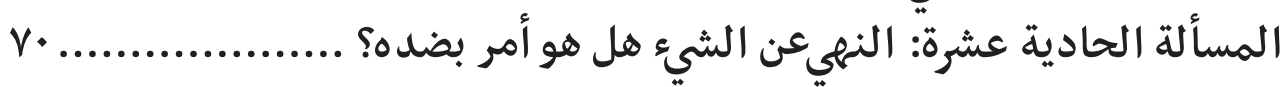

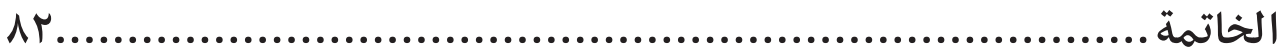

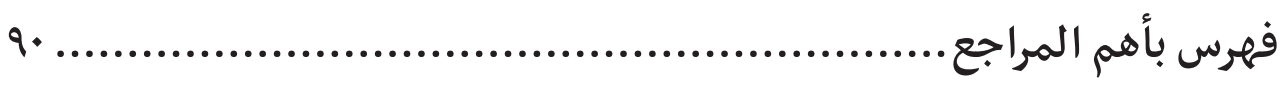
$1 \cdot v$

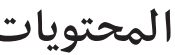
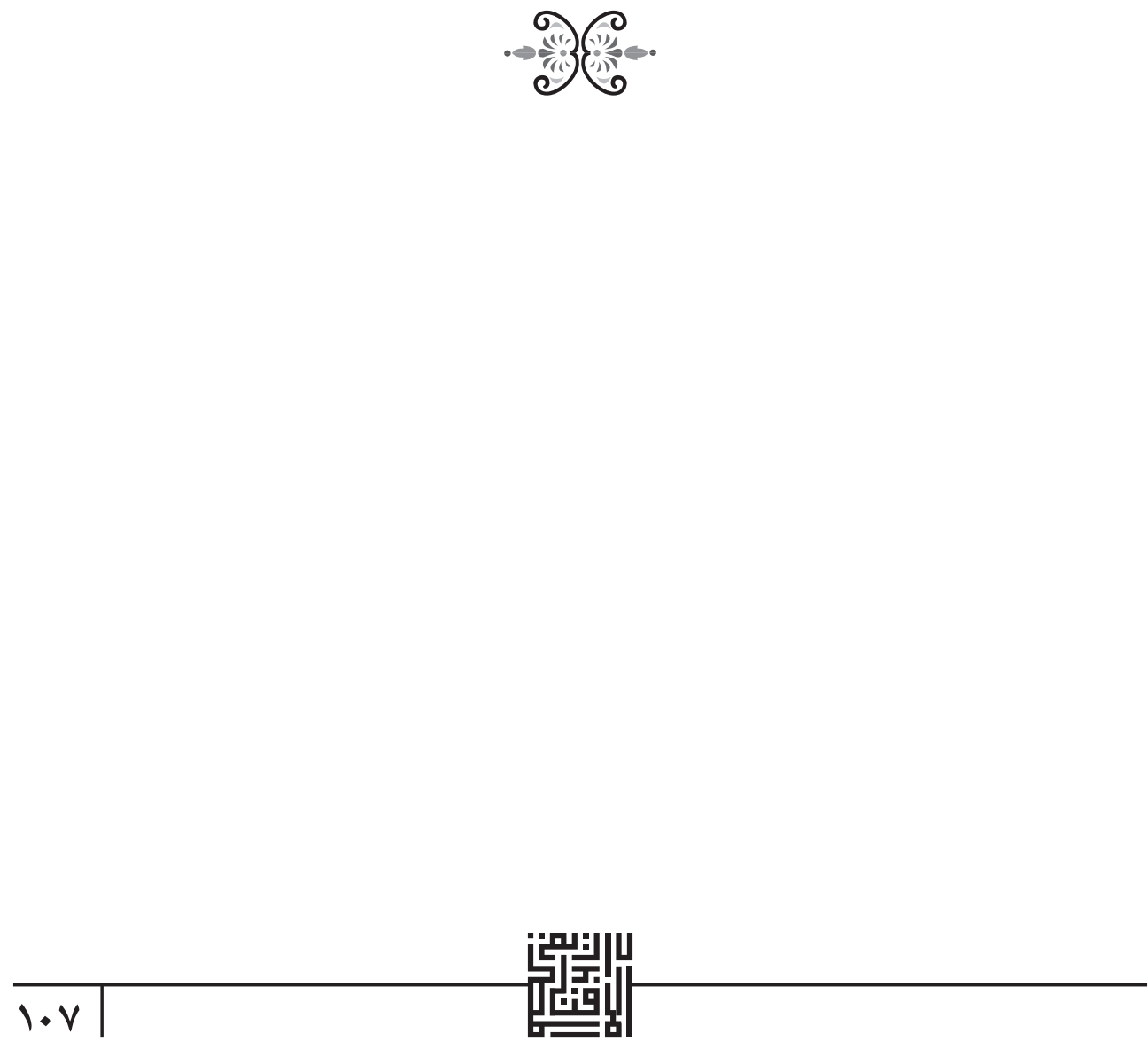